Universidade de Brasília

Centro de Excelência em Turismo

\title{
Qualidade da atividade turística - perfil, motivação e percepção do visitante: Um estudo de caso do Município de Pirenópolis / GO
}

\author{
ANA PAULA ESTEVAM MELO
}

Orientadora: Prof ${ }^{a}$.Dra.Tânia Montoro

Monografia apresentada ao Centro de Excelência em Turismo da Universidade de Brasília como requisito parcial para a obtenção do certificado de Especialista em Docência e Pesquisa em Turismo e Hospitalidade

Brasília, DF, dezembro de 2003. 
UNIVERSIDADE DE BRASÍLIA

Centro de Excelência em Turismo

Curso de Especialização para Professores e Pesquisadores em Turismo e Hospitalidade

\title{
Qualidade da atividade turística - perfil, motivação e percepção do visitante: \\ Um estudo de caso do Município de Pirenópolis / GO
}

\section{ANA PAULA ESTEVAM MELO}

\author{
Banca Examinadora
}

Orientadora: Prof ${ }^{a}$. Dr ${ }^{\mathrm{a}}$.Tânia Montoro

Brasília, DF, 04 de dezembro 2004. 
MELO, Ana Paula Estevam

Qualidade da atividade turística - perfil, motivação e percepção do visitante: Um estudo de caso do Município de Pirenópolis / GO / Ana Paula Estevam Melo / UnB / Brasília, 2003.

xiv, 162 pág.:il.

Especialização para Professores e Pesquisadores em Turismo e Hospitalidade.Universidade de Brasília, Centro de Excelência em Turismo, 2003.

The study case from the Pirenópolis city.

1. Turismo. 2. Pesquisa. 3. Dados - Monografia.

I. Monografia (Especialização) - Centro de Excelência em Turismo. II.Qualidade da atividade turística - perfil, motivação e percepção do visitante: um estudo de caso do Município de Pirenópolis. 
Qualidade da atividade turística - perfil, motivação e percepção do visitante:

Um estudo de caso do Município de Pirenópolis / GO

Comissão Avaliadora

$\overline{\text { Professora Orientadora Dr }{ }^{\mathbf{a}} \text {.Tânia Montoro }}$

Professor (a)

Professor (a)

Brasília, DF, 04 de dezembro de 2003 
Este trabalho é dedicado aos meus pais: Maia e Prudência, aos meus tios César e Marilete e suas filhas Ana Carolina e Gabriela. 
Agradeço a minha professora orientadora Tânia Montoro, meu namorado Fred e minhas queridas amigas Carla, Sônia e Karina. 
"Só tem algo a ensinar aquele que, por meio da pesquisa, construiu uma personalidade própria científica, aquele que tem uma contribuição original; caso contrários, não vai além de narrar aos estudantes o que leu por aí". (Demo, 1981, pág.07). 


\section{RESUMO}

O presente trabalho é resultado de um estudo realizado com os subsídios de uma pesquisa no município histórico de Pirenópolis - Goiás em quatro ocasiões distintas do ano de 2003: Semana Santa (16 a 21 de abril); Final de Semana Comum (16 a 18 de maio); Festa do Divino - Cavalhadas (08 e 09 de junho) e Férias (11 a 17 de julho). No primeiro momento foi feito um estudo de sondagem levantando situação problema e as hipóteses que dela derivam. No segundo momento, foram aplicados questionários em lócus e posteriormente, realizados a classificação e tabulação dos questionários. Finalizando, apresento a análise dos resultados obtidos, que confirmam a hipótese de que o Município de Pirenópolis tem conseguido desenvolver a atividade turística com qualidade, sendo necessários, entretanto, algumas reorientações em termos de prioridade de ações integradas e de parcerias.

É interessante ressaltar que este projeto aconteceu a partir de uma situação problema com relação à qualidade da atividade turística e para interpretar de modo específico esta preocupação, utilizamos levantamentos que relatam o perfil, a motivação e a percepção do visitante neste município.

Para embasamento teórico desta monografia e para que esse projeto viesse contribuir, de alguma forma, para a melhoria da qualidade dos serviços turísticos prestados pelo Município de Pirenópolis, buscamos a orientação de pesquisas realizadas por: Campos, Cobra, Dencker, Demo, Luna, Montoro, Mendonça, Nicoletti, Oliveira, Rangel, Pádua, Sâmara e Barros, Stablein. Espera-se que este projeto venha auxiliar na realização de outros projetos nesta área. 


\begin{abstract}
This present work is a resulted of study and research at Pirenópolis city, in Goiás state in four different occasions in the year 2003: Easter week $\left(16^{\text {th }}\right.$ to $21^{\text {st }}$ of April); Normal weekend ( $16^{\text {th }}$ to $18^{\text {th }}$ of May); Divino's Party - Cavalhadas ( $08^{\text {th }}$ to $09^{\text {th }}$ of June) and Vacation ( $11^{\text {th }}$ to $17^{\text {th }}$ of July). Where, at the first moment a study of the situation has been made and the hypothesis has been raised. At the second moment, questionnaires were applaud in writing pad, later, the questionnaires were tabulated and concluding with the analysis' result, which confirms the hypothesis that Pirenópolis city has been giving quality to the tourism services, but with some necessary adaptations.

Is really interesting to just out, that this project will contribute, somehow, to the improvement of the tourism service quality that.

The theoretical base so that project came to contribute, in some way, for the improvement of quality of the tourism services. Pirenópolis city gives were necessary to look for some authors, as: Campos, Cobra, Dencker, Demo, Luna, Montoro, Mendonça, Nicoletti, Oliveira, Rangel, Pádua, Samara e Barros, Stablein. The expectations are that, this project can auxiliary in the accomplishment in others project in this area.
\end{abstract}




\section{SUMÁRIO}

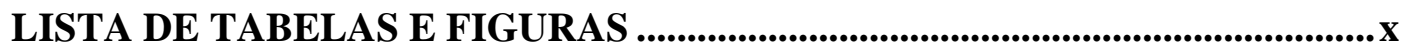

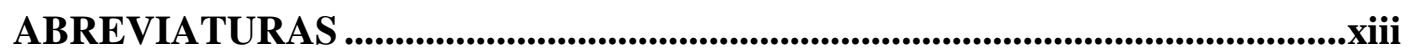

LISTA DE ABREVIATURAS...........................................................................

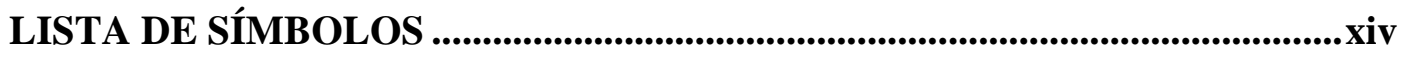

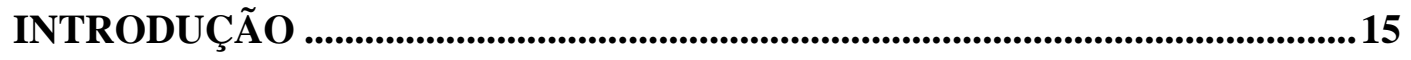

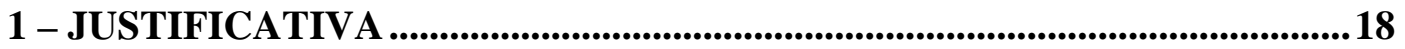

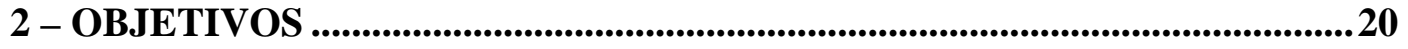

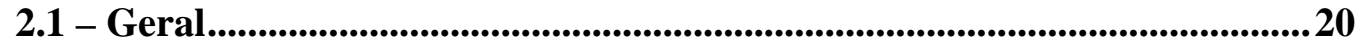

2.2 - Específicos....................................................................................................................... 20

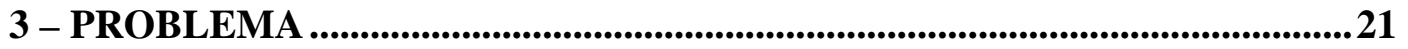

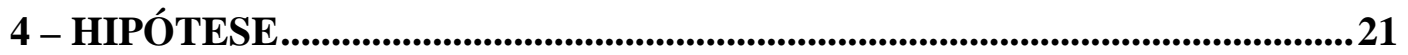

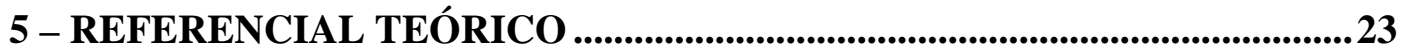

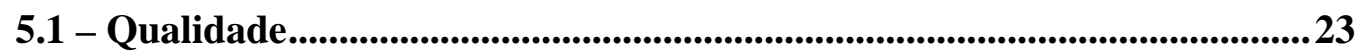

5.2 - Conta Satélite do Turismo _.....................................................................225

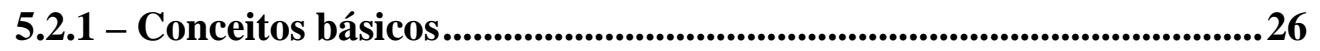

5.2.1.1 - Demanda.................................................................................................26

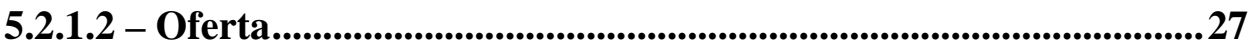

5.3 - Plano Nacional do Turismo (2003 - 2007) ........................................................28

5.3.1 - Macro Programa 1: Gestão e Relações Institucionais ........................28

5.3.2 - Macro Programa 2: Fomento.................................................................. 28

5.3.3 - Macro Programa 3: Infra-estrutura ......................................................28

5.3.4 - Macro Programa 4: Estru. e Diversificação da Oferta Turística ... 28

5.3.5 - Macro Programa 5: Qualidade do Produto Turístico ...................... 28

5.3.6 - Macro Programa 6: Promoção e Apoio a Comercialização.............29

5.3.7 - Macro Programa 7: Informações Turísticas .......................................29

5.3.7.1 - Descrição do Macro Programa 7 ..................................................29

5.3.7.2 - Objetivos do Macro Programa 7..................................................30

5.4 - Plano Estadual de Turismo do Estado de Goiás (2003 - 2007) ................ 30

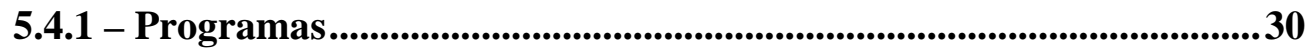

5.4.1.1 - Programa Mostra Goiás ..........................................................30

5.4.1.2 - Programa Infra-estrutura Turística.........................................30

5.4.1.3 - Programa Inteligência Turística ................................................... 31 
5.4.1.4 - Programa de Produto Turístico ....................................................31

5.4.2 - Objetivos do Plano Estadual de Turismo ............................................31

\section{CAPÍTULO II}

6 - METODOLOGIA DA PESQUISA .............................................................32

6.1 - Definição dos métodos de pesquisa......................................................................332

6.1.1 - Pesquisa exploratória.......................................................................................... 33

6.1.2 - Pesquisa descritiva ........................................................................................33

6.1.2.1 - Estudos descritivos estatísticos...................................................33

6.1.2.2 - Estudos descritivos de caso .....................................................34

6.1.3 - Pesquisa experimental ou casual ......................................................34

6.1.4 - Métodos de coleta de dados ..............................................................34

6.1.4.1 - Método de observação...............................................................................35

6.1.4.2 - Método de inquérito ou contato ...................................................35

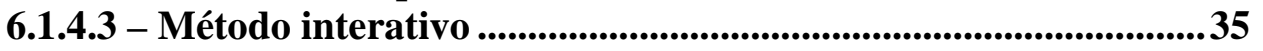

6.1.5 - Elaboração do instrumento para coleta de dados ...............................36

6.1.6 - Tipos de perguntas...........................................................................................37

6.1.7 - População .........................................................................................................37

6.1.8 - Tabulação......................................................................................................... 37

6.1.9 - Análise dos dados ................................................................................38

6.2 - Perfil, Motivação e Percepção do Visitante ...................................................... 39

6.2.1 - Operacionalização das variáveis ..................................................39

6.2.1.1 - Perfil do Visitante.....................................................................39

6.2.1.2 - Motivação do Visitante ................................................................... 40

6.2.1.3 - Percepção do Visitante........................................................................40

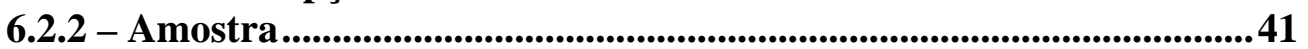

6.2.3 - Instrumento de coleta de dados .............................................................4 41

6.2.4 - Procedimentos de coleta de dados ...........................................................42

6.2.5 - Locais e periodicidade de aplicação dos questionários ......................42

6.3 - Cronograma de Atividades ................................................................................43

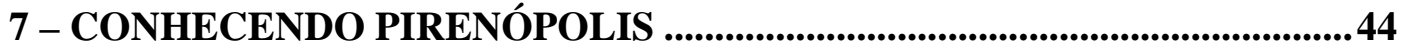

7.1 - Histórico do município ........................................................................................44

7.2 - Infra-estrutura urbana...................................................................................4

7.3 - Áreas de preservação .............................................................................48

7.4 - Caracterização ...................................................................................................48

7.5 - Manifestações culturais ...........................................................................50

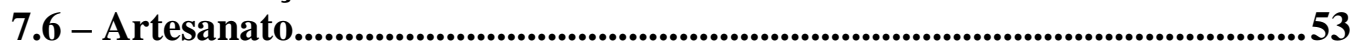

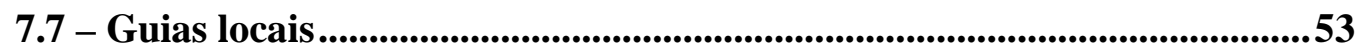

\section{CAPÍTULO IV}

8 - ANÁLISE DOS DADOS DO LEVANTAMENTO ......................................54

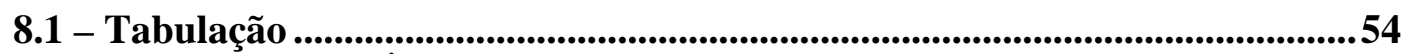

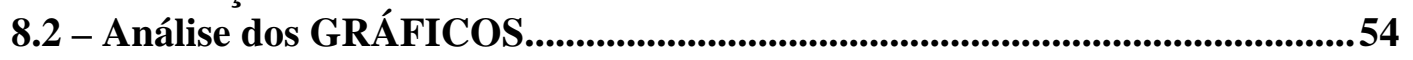

8.2.1 - Semana Santa ...................................................................................................... 54

8.2.2 - Final de Semana Comum .....................................................................55

8.2.3 - Festa do Divino - Cavalhadas .......................................................59

8.2.4 - Férias de Julho ...............................................................................61 
8.3 - Formatação dos dados em TABELAS ......................................................63

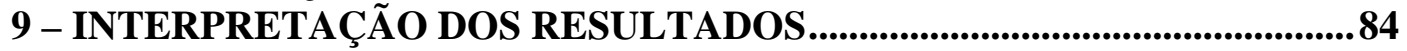

9.1 - Tendências ........................................................................................................................8 84

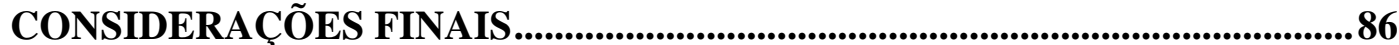

ANEXOS

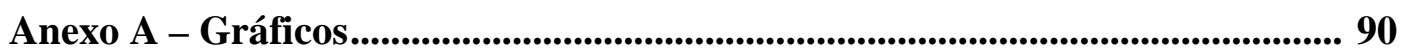

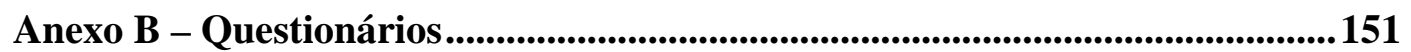

REFERENCIAS BIBLIOGRÁFICAS .................................................................. 160 


\section{LISTA DE TABELAS E FIGURAS}

\section{PERFIL DO VISITANTE}

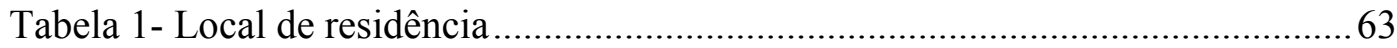

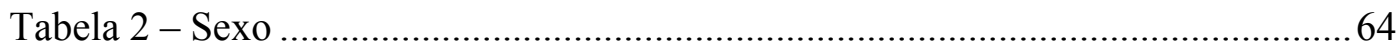

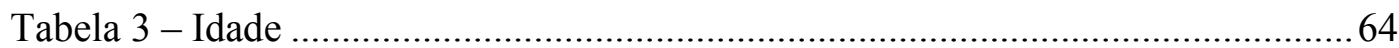

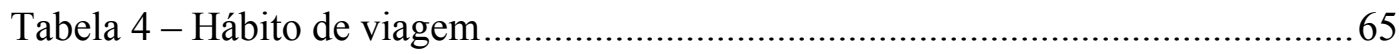

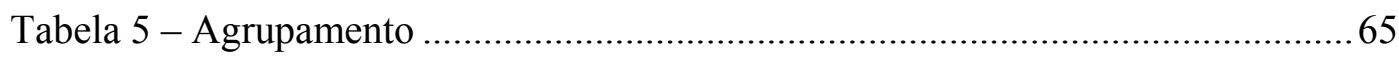

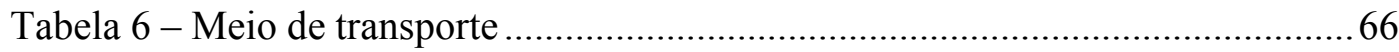

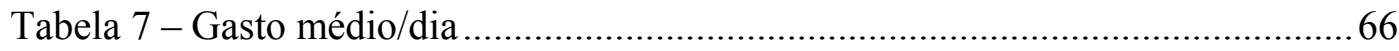

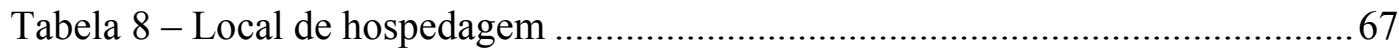

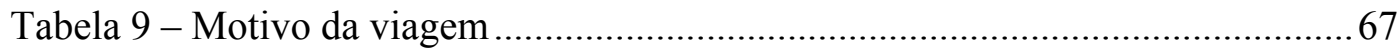

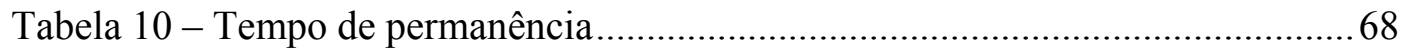

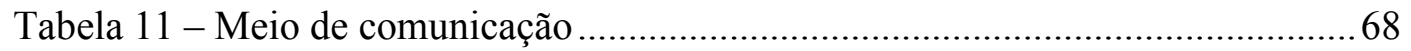

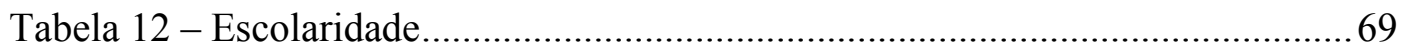

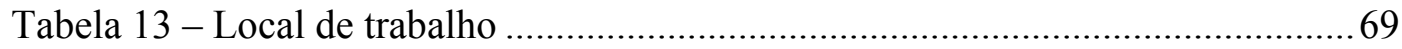

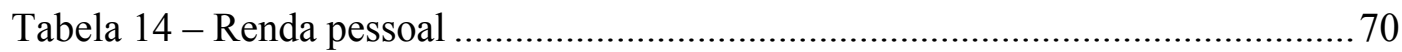

Tabela 15 - Atividade durante a viagem ..................................................................... 70

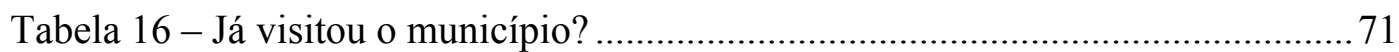

Tabela 17 - Pretende voltar ao município? .............................................................. 71

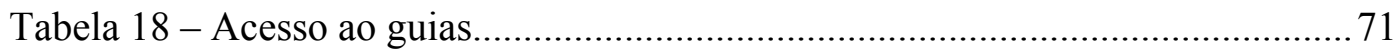

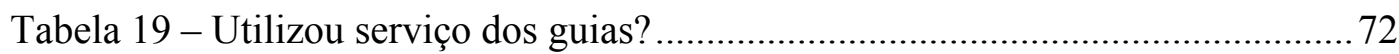

Tabela 20 - Avaliação dos serviços dos guias ........................................................... 72

\section{PERCEPÇÃO DO VISITANTE}

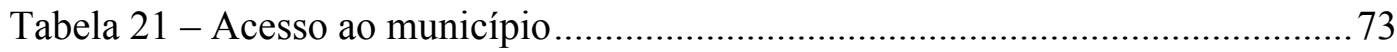

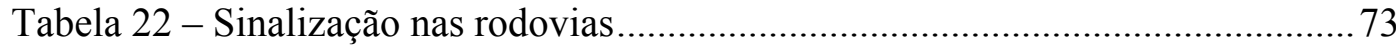

Tabela 23 - Sinalização dentro do município ............................................................ 73 


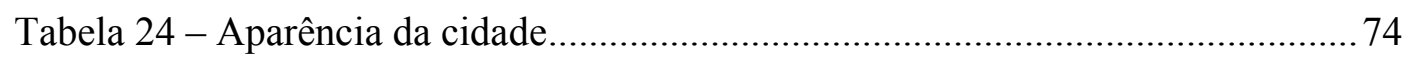

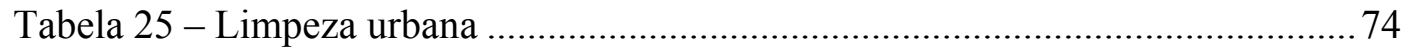

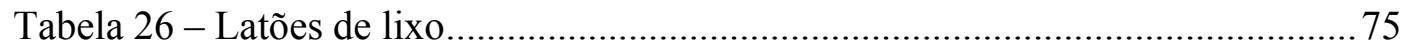

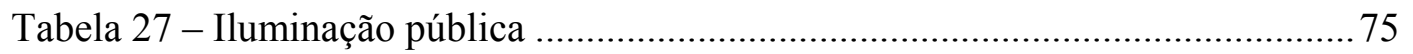

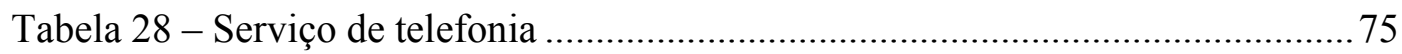

Tabela 29 - Serviço de transporte de uso público..................................................... 76

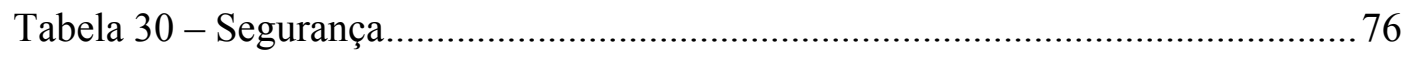

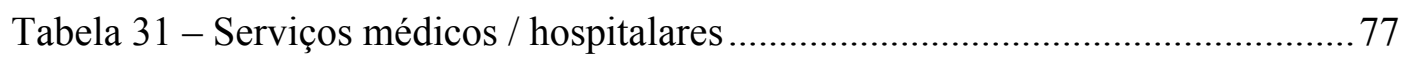

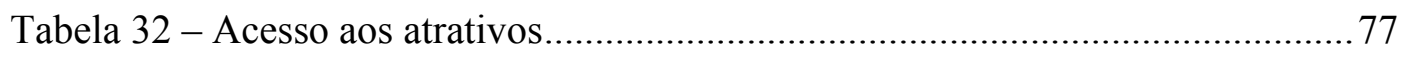

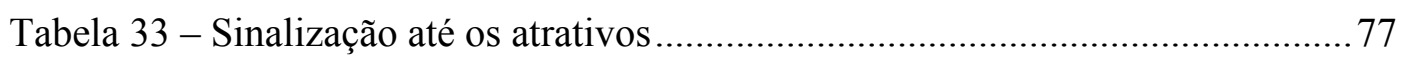

Tabela 34 - Sinalização dentro dos atrativos .......................................................... 78

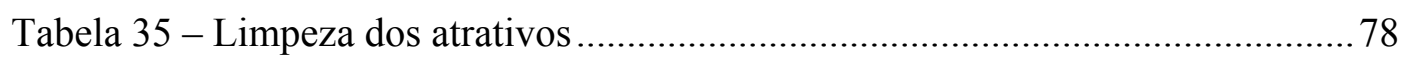

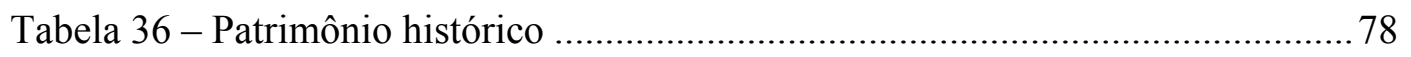

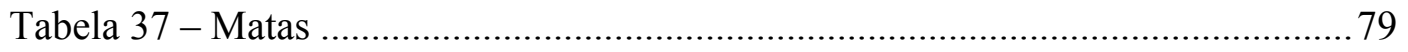

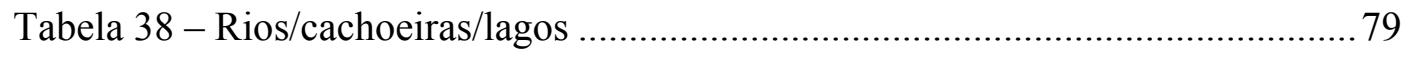

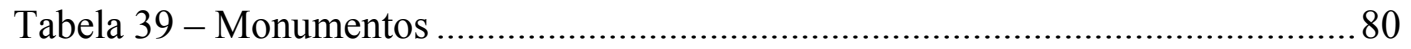

Tabela 40 - Cavernas/grutas/serras/morros........................................................ 80

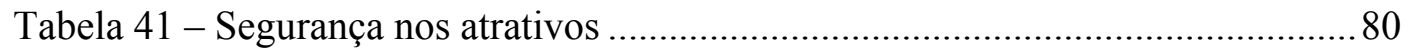

\section{AVALIAÇÃO DOS EQUIPAMENTOS E SERVIÇOS TURÍSTICOS}

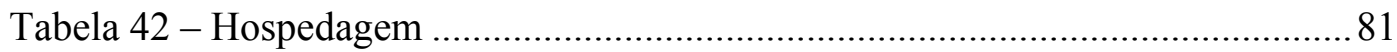

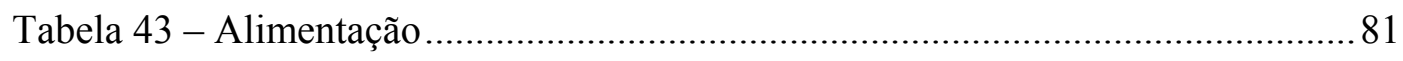

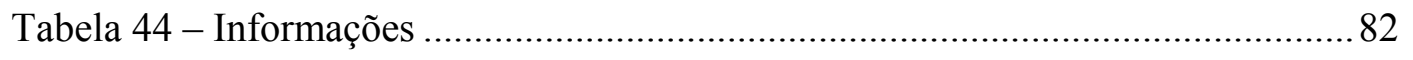

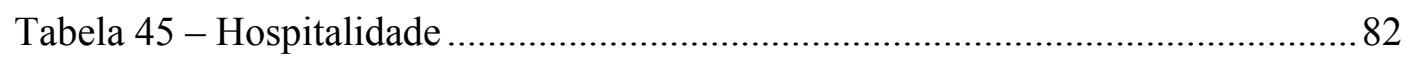

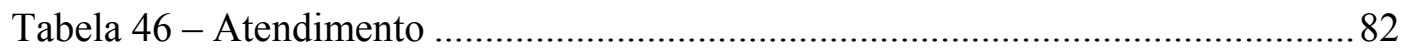

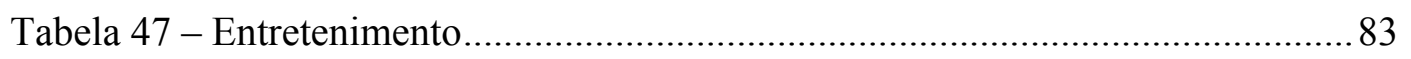

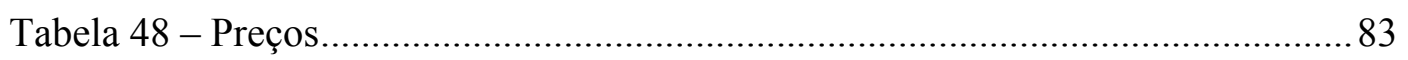

\section{GRÁFICOS}

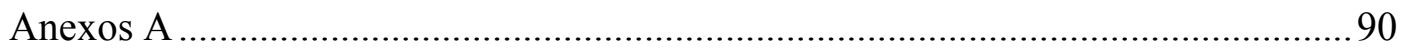

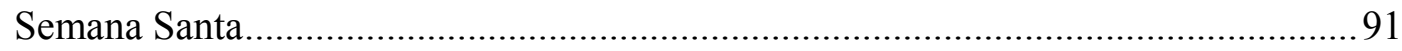

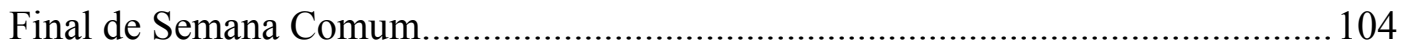

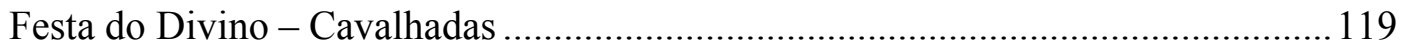


Férias de Julho.

\section{QUESTIONÁRIOS}

Anexos B

151

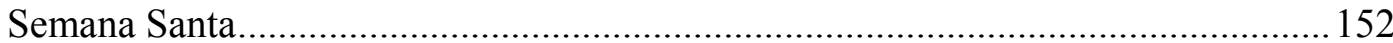

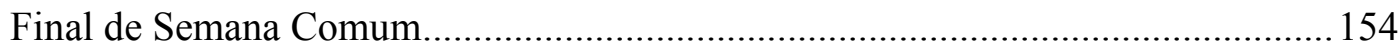

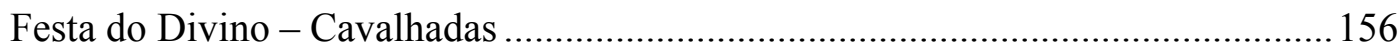

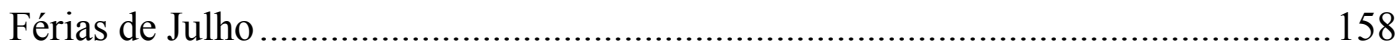




\section{ABREVIATURAS}

CET/UnB ................... Centro de Excelência em Turismo da Universidade de Brasília IBGE InstitutoBrasileiro de Geografia e Estatística

PIB Produto Interno Bruto

IDH Índice de Desenvolvimento Humano

AGETUR Agencia Goiana de Turismo

SEBRAE Serviço Brasileiro de Apoio às Micro e Pequenas Empresas

GO Goiás

SEPLAN Secretaria de Planejamento e Desenvolvimento do Estado de Goiás CEFET Centro Federal de Educação Tecnológica de Goiás $\mathrm{DN}$ Departamento Nacional CST Conta Satélite do Turismo

OMT Organização Mundial de Turismo

EMBRATUR Instituto Brasileiro de Turismo

ONU Organização das Nações Unidas

C.T. Consumo Turístico CAT Centro de Atendimento ao Turista SANEAGO Saneamento de Goiás S/A RPPNs Reservas Particulares do Patrimônio Natural APA Área de Proteção Ambiental IBAMA Instituto Brasileiro do Meio Ambiente GT Grupo de Trabalho 


\section{LISTA DE ABREVIATURAS}

\begin{tabular}{|l|l|}
\hline \multicolumn{1}{|c|}{ Abreviatura } & \\
\hline Fev. & Fevereiro \\
\hline Mar. & Março \\
\hline Abr. & Abril \\
\hline Maio & Maio \\
\hline Jun. & Junho \\
\hline Jul. & Julho \\
\hline Ago. & Agosto \\
\hline Set. & Setembro \\
\hline Out. & Outubro \\
\hline Nov. & Novembro \\
\hline Dez. & Dezembro \\
\hline et.al; et alii. & E outros; \\
\hline Ex. & Exemplo \\
\hline C/ & Com \\
\hline Apart. & Apart hotel \\
\hline Obs. & Observação \\
\hline Estru. & Estruturação \\
\hline & \\
\hline
\end{tabular}

\section{LISTA DE SÍMBOLOS}

$\Sigma$.

Somatório

/.

Divisão

$+\ldots$

Soma

$=$

Igualdade

$\mathrm{X}$

Multiplicação

$\%$

Porcentagem

Sem resposta 


\section{INTRODUÇÃO}

“Goiás é beleza em estado natural. Aqui pulsa o coração do Brasil, mostrando ao mundo toda as qualidades desta terra abençoada...”. (Marconi Perillo, Governador do Estado de Goiás). São incomparáveis suas belezas naturais, com cenários paradisíacos.

Sua localização geográfica é privilegiada, está no coração do país, o que anuncia um fator importante: do meio do País qualquer distancia fica menor. Tem extraordinárias vantagens na área de turismo e ecoturismo. E, já é importante centro de recepção de eventos e convenções.

Segundo o IBGE, o PIB goiano vem crescendo desde 1996 a taxas superiores a nacional. Ocupa o sétimo lugar no país pelo Índice de Desenvolvimento Humano (IDH) das Nações Unidas é o décimo estado em renda, o oitavo em educação, o nono em saúde. Uma das alternativas de crescimento econômico para alavancar ainda mais o Estado é o turismo e o ecoturismo, dado o acervo de atrações naturais e culturais de Goiás. (Fonte: Goiás em EXAME /23 de abril de 2003).

Acervo, que envolve todo o estado, recoberto pela vegetação do cerrado, com mais de 500 tipos de árvores, 200 qualidades de orquídeas, mais de 400 espécies de aves, 160 espécies de mamíferos e mil variedades de borboletas multicores.(Show Case de Goiás, 2002, pág.07). Tudo isso, servindo de cenário para as inúmeras manifestações culturais de um povo alegre e festeiro.

Povo oriundo da mistura do colonizador europeu com escravo africano e com indígena nativo. Desta miscigenação surgiu a cultura de Goiás, com suas crenças e festas, suas danças e culinária, seus tons na fala e na arquitetura. É muito rica a cultura goiana. (Show Case de Goiás, 2002, pág.15). 
Goiás é um estado com grande diversidade natural, histórica e cultural, para facilitar o desenvolvimento do turismo sustentável, o Governo Estadual através da AGETUR (Agencia Goiana de Turismo) em parceria com o SEBRAE (Serviço Brasileiro de Apoio às Micro e Pequenas Empresas) criaram “Os Caminhos de Goiás” que foram classificados em quatro rotas: Caminho do Sol; Caminho das Águas; Caminho da Biosfera e Caminho do Ouro.

Caminho do Sol - roteiro que se inicia no Parque Nacional das Emas (Sítio Natural do Patrimônio Mundial e Reserva da Biosfera do Pantanal), Chapadão do Céu, Mineiros, Serranópolis, Aragarças, Lago dos Tigres, Aruanã, Bandeirantes, Luís Alves, locais que fazem de Goiás um cenário perfeito para o ecoturismo e a pesca esportiva.

Caminho das Águas - são formados pelas águas quentes das fontes termais de Caldas Novas e Rio Quente, lagos de barragens para produção de energia elétrica, nas cidades de Cachoeira Dourada, Itumbiara, Emborcação, Lago Azul e São Simão, lago de Três Ranchos e Lagoa Santa com suas águas medicinais.

Caminho da Biosfera - onde encontram as reservas da Biosfera do Cerrado e o Parque Nacional da Chapada dos Veadeiros em São Jorge e Ato Paraíso, Sítios Naturais do Patrimônio Mundial, o parque Municipal de Itiquira, no município de Formosa, o Parque Nacional de Terra Ronca, sítios arqueológicos e a comunidade dos Kalungas, negros remanescentes de quilombo. Esta região é ideal para pratica de esportes radicais e ecoturismo.

Caminho do Ouro - cidades encantadoras como a Cidade de Goiás, Pirenópolis, Corumbá, Jaraguá e tantas outras que conservam o patrimônio histórico e cultural de imenso valor. A cidade de Goiás, Sítio Histórico do Patrimônio Mundial, possui riqueza arquitetônica do período colonial, restaurado e conservado com o tempo. Pirenópolis, Patrimônio Histórico Nacional, é outra bela cidade, com suas charmosas vielas, os casarões e a arquitetura colonial, tudo isso em meio às atrações naturais do Parque Estadual da Serra dos Pirineus e suas dezenas de cachoeiras. 
E, é no município de Pirenópolis que iniciamos o Projeto Piloto de Pesquisa Turística no Estado de Goiás, juntamente com o Planejamento Integrado e Participativo da Pesquisa Turística que visa criar um banco de dados do turismo em Goiás. São parceiros deste programa: a AGETUR, o SEBRAE e as Instituições de Ensino Superior que possuem curso de Turismo no estado de Goiás.

Através de reuniões periódicas e itinerantes, o grupo que faz parte do Planejamento Integrado e Participativo da Pesquisa Turística, estuda e pensa as melhores formas de desenvolver sustentavelmente o turismo no Estado de Goiás. E, uma destas formas é a pesquisa, realizada nos municípios previamente determinados e que são classificados como turísticos.

O projeto selecionou o município de Pirenópolis para iniciar seu levantamento de dados em quatro ocasiões distintas:

Semana Santa - abril de 2003;

Final de semana comum - maio de 2003,

Festa do Divino (Cavalhadas) - maio de 2003

Férias - julho de 2003

Para tanto, utilizaremos destas pesquisas realizadas ao longo do ano de 2003, para levantar questionamentos pertinentes ao desenvolvimento ordenado do Turismo no município de Pirenópolis / GO, bem como, avaliar a qualidade da atividade turística através da analise do perfil, motivação e percepção do visitante desta localidade. 


\section{1 - JUSTIFICATIVA}

Obter conhecimento atualizado e informações detalhadas sobre os municípios turísticos do estado de Goiás, permitirá uma aproximação do poder publico e da iniciativa privada em prol do desenvolvimento sustentável do turismo no estado de Goiás. Os dados e informações que este projeto vem a levantar associado a outros, como as pesquisas anteriores, levantamento de outras instituições, trabalhos curriculares das Instituições de Ensino Superior possibilitarão a construção de um sistema de indicadores estatísticos do Turismo que alimentará um banco de dados único no Estado e funcionará como efetivo instrumento de planejamento estratégico, além de se constituir em elemento essencial para análise do desempenho da atividade turística e conseqüentemente, auxiliará na captação de recursos e investimentos.

Os trabalhos de pesquisas turística nos Caminho de Goiás foram iniciados em 2000 na cidade de Aruanã. No ano de 2001, sob a supervisão da Fundação Aroeira (Fundação vinculada a Universidade Católica de Goiás), foi firmado convênio com as Instituições de Ensino Superior, que desenvolveram trabalhos no Caminho do Sol, em específico, nas cidades de Aruanã, Aragarças, Bandeirantes, Britânia e Luís Alves, no mês de julho.

Em 2002, foi criado o núcleo de pesquisa da AGETUR, que tem a finalidade de motivar e buscar parcerias junto as Instituições de Ensino Superior e demais empresas para realização contínua da pesquisa turística nos municípios goianos.

E, finalmente, no ano de 2003, objetivando levantar subsídios para a elaboração e planejamento de um programa integrado da pesquisa turística voltado para a criação de um banco de dados da atividade turística de Goiás, foi realizado o evento com o tema: Planejamento Integrado e Participativo da Pesquisa Turística em Goiás coordenado pela AGETUR em parceria com o SEBRAE em Goiás.

A partir desse encontro, foram discutidos vários aspectos que colaboraram para a modelagem e estruturação do programa. Foi criado o Grupo de Trabalho (GT) com o intuito 
de pensar e desenvolver o programa. O GT se comprometeu em realizar encontros a cada 14 dias para discutir a pesquisa turística em Goiás. Nestas oficinas itinerantes são apresentados os temas de interesse de cada participante e todas as decisões são tomadas em plenária.

São parceiros do programa:

- SEPLAN (Secretaria de Planejamento e Desenvolvimento do Estado de Goiás)

- ARQUIDATA

- FACULDADE ANHANGUERA

- SECRETARIA MUNICIPAL DE TURISMO DE GOIÂNIA

- FACULDADE ALFA

- FACULDADE LIONS

- FACULDADE CAMBURY

- CEFET (Centro Federal de Educação Tecnológica de Goiás)

- UNIVERSidAde eStaduAL DE GOIÁs

- UNIVERSIDADE FEDERAL DE GOIÁS

- SECRETARIA DE CIÊNCIA E TECNOLOGIA

- AgETUR (Agencia Goiana de Turismo)

- SEBRAE (Serviço Brasileiro de Apoio às Micro e Pequenas Empresas)

- UNIVERSIDADE CATÓLICA DE GOIÁS

- UNIVERSIDADE PAULISTA

- FACULDADES OBJETIVO

- IBGE (Instituto Brasileiro de Geografia e Estatística)

- GUPO NATIVA

- PROFISSIONAIS DE TURISMO

Para dar inicio as atividades de campo, foi necessário definir um Projeto Piloto e escolher um município a ser pesquisado e o município contemplado foi o de Pirenópolis, um dos mais representativos para o desenvolvimento turístico do Estado. Foi desenvolvido um projeto específico, abordando o perfil, motivação e percepção dos visitantes tomados em quatro momentos distintos, tornando a amostragem mais significativa. 
Para efeito desta monografia de final de curso, utilizaremos o estudo de caso do município turístico de Pirenópolis para traçar o perfil do turismo e do turista que freqüenta aquela localidade. E, conseqüentemente, avaliar se o município desenvolve atividade turística com qualidade.

\section{2 - OBJETIVOS}

\section{1 - Geral}

Caracterizar e dimensionar os serviços turísticos através de levantamento dos dados relativos ao Visitante (perfil, motivação e percepção) do Município turístico de Pirenópolis no estados de Goiás.

\section{2 - Específicos}

- $\quad$ Identificar o perfil, a motivação e a percepção dos visitantes;

- Constatar a prestação de serviço turístico de qualidade;

- Apresentar métodos de pesquisa para o levantamento de dados que possam dimensionar e caracterizar o visitante do Município de Pirenópolis;

- Mostrar a importância da pesquisa para um município turístico;

- $\quad$ Fornecer subsídios para estudos de viabilidade em prol do crescimento turístico do município. 


\section{3 - PROBLEMA}

Cada vez mais, as pessoas se permitem ao "ócio", para tanto, procuram lugares que satisfaçam suas necessidades de descanso e fuga do cotidiano das grandes cidades. A atividade turística é a grande causadora desta busca constante, pois proporciona satisfação das necessidades através da prestação de serviços com qualidade ou não, em lugares paradisíacos.

..., turista são pessoas que estão de férias, que dispõem de dias livres e procuram o que fazer para ocupa-los. Decidem para onde vão viajar de acordo com as melhores propostas de ocupação do tempo livre, procurando informações nos jornais, nos folhetos, nas agencias de viagem ou consultando amigos. Os locais que apresentam as melhores condições para mantê-los ocupados vão, facilmente, atraí-los e vencer os concorrentes".

(Oliveira, 2002, pág. 44).

E, um exemplo deste tipo de lugar é a cidade de Pirenópolis no estado de Goiás, um município classificado como turístico, que possui inúmeros atrativos e serviços que o caracterizam como tal.

\section{4-HIPÓTESE}

O Município de Pirenópolis é caracterizado como turístico, para tanto, é necessário qualificação da oferta, ou seja: atrativos turísticos aprazíveis (“...todo lugar, objeto ou acontecimento de interesse turístico que motiva o deslocamento de grupos humanos") (Oliveira, 2002, pág 65), equipamentos e serviços turísticos ("entendido como o conjunto de edificações, instalações e serviços indispensáveis ao desenvolvimento da atividade turística , são constituídos pelos meios de hospedagem, alimentação, entretenimento, agenciamento, informações e outros serviços voltados para o atendimento aos turistas”). (Oliveira,2002,pág 66) e infra-estrutura de apoio turístico ("formada pelo conjunto de obras e instalações de estrutura física de base que proporciona o deslocamento da atividade turística, tais como o sistema de comunicação, transporte, serviços urbanos"). 
EMBRATUR. Inventário da oferta turística. Brasília: Ministério da Industria, do Comércio e do Turismo, 1998, p.10).

Analisando as características citadas anteriormente perguntamos:

- O Município de Pirenópolis tem conseguido prestar serviços turísticos de qualidade aos seus visitantes?

- Possui equipamentos para o bom desenvolvimento da atividade turística?

- Dispõe de atrativos turísticos aprazíveis?

- A infra-estrutura do município é adequada para o desenvolvimento do turismo?

- Qual o perfil e a motivação do visitante? 


\section{CAPÍTULO I}

\section{5 - REFERENCIAL TEÓRICO}

O tema abordado neste projeto de pesquisa é a qualidade da atividade turística desenvolvida no Município de Pirenópolis - GO, analisando o perfil, a motivação e a percepção do visitante, e para o desenvolvimento do tema em questão, é imprescindível correlacionar a pesquisa com o universo teórico, optando-se por um modelo que sirva de embasamento à interpretação do significado dos dados coletados e analisados.

\section{1 - Qualidade}

Para efeito da monografia utilizaremos o termo qualidade:

Atualmente, os serviços se mostram bem mais complexos e sofisticados, a competitividade cresce dia após dia, o nível de exigência dos clientes se aprimora e a qualidade passa a ser o principal fato de diferenciação em tudo. Isso implica, é claro, novos e maiores desafios a serem vencidos pelos trabalhadores, em face do maior rigor no controle de qualidade dos serviços prestados.

Faz-se necessário estar atento para o que pode ser melhorado no processo da qualidade em todos os níveis de produção de serviços e produtos. As necessidades têm sentidos diferentes de uma pessoa para outra e portanto, a qualidade também.

As definições de qualidade são muitas. Variam de pessoa para pessoa, de especialista para especialista. É possível dar algumas definições. Por exemplo: qualidade é adequação ao uso; qualidade é aquilo que não cria problema; qualidade é fazer a coisa certa na primeira vez.

(Rangel, 1950, pág.1) 
Certamente em inúmeras situações nós deparamos com a palavra qualidade. Mas qual o real sentido de qualidade?

Bom padrão de qualidade representa alguma coisa bem-feita, bem concebida, bem projetada, bem elaborada, bem organizada, bem administrada, que atende as especificações, satisfazendo, assim, produtores, prestadores de serviços e clientes. Qualidade, então, é a totalidade de características de alguém, ou de alguma coisa, que lhe confere a capacidade de atender as necessidades explícitas e implícitas.

Necessidades explícitas são aquelas expressas formalmente, seja em contratos, em especificações de projetos, em folhetos promocionais, material de propaganda, manual de operação de equipamentos, etc. elas tratam de questões objetivas.

As necessidades implícitas, por sua vez, dizem respeito às expectativas ou aos desejos dos clientes. Portanto, não podem estar formalmente ou predeterminadas em nenhum documento. Essas necessidades têm a ver com questões de ordem subjetiva, mais ligadas ao modo de pensar das pessoas de uma maneira geral.

(SENAC/DN, 1999, pág.15 e 16)

A qualidade de um serviço é, sem dúvida, essencial ao perfeito funcionamento de qualquer estrutura prestadora de serviços.

Quando falamos de um serviço de qualidade estamos nos referindo á plena satisfação do cliente. E o segredo para isso é concentrar-se profundamente nas necessidades e nos desejos do cliente, criando um serviço que atenda ou exceda as suas expectativas...

(SENAC/DN, 1999, pág. 18 e 19)

São as pessoas que fazem com que os serviços sejam diferenciados pelo atendimento prestados aos clientes. Os atuais especialistas em administração são unânimes em afirmar que pessoas amistosas, cordiais, educadas e competentes, quando prestam um serviço, são mais valiosas do que a mais sofisticada tecnologia.

Pode-se concluir que, a qualidade na prestação de um serviço se faz presente quando ele garante a plena satisfação do cliente. Para tanto, o serviço deve ser bem feito e ter um preço justo e, além disso, não deve dar lugar a desperdícios. Assim, o cliente vai consumilo novamente e se tornar o divulgados daquele serviço e de sua qualidade. 


\section{2 - Conta Satélite do Turismo}

Para auxiliar na analise dos dados coletados e também, para a criação dos questionários, foram utilizadas as definições contidas na Conta Satélite do Turismo (CST) e também, seguindo os propósitos do Plano Nacional do Turismo 2003 - 2007 do governo vigente. Que vem de encontro como método de análise da demanda e oferta turística para um detalhamento dentro do quadro da Contas Nacionais do País. Modelo que segue a proposta realizada pela Organização Mundial do Turismo - OMT e o Instituto Brasileiro de Turismo EMBRATUR. O modelo proposto permite que possa ser avaliado o turismo de forma temporal e comparado de forma internacional, criando um método único de análise dos dados.

A OMT sugere a criação de modelos padronizados de construção da CST para seus países membros, com vista a dispor de informações fidedignas e consistentes, como suporte a estudos e avaliação do impacto sócio-econômico do Turismo.

A grande importância do modelo da CST é sua contribuição para a economia, com dados relativos a demanda do turista, as taxas geradas pela atividade, o trabalho e a disponibilidade desses dados para indústrias, governo e população. Isso porque, o turismo é uma atividade singular que apresenta complexas interfaces com outros setores de atividade, merecendo, por isso, um tratamento especial. E, uma destas soluções é a da Conta Satélite do Turismo proposta pela OMT.

A conta satélite do turismo tem 10 quadros de resumo que contemplam conceitos e classificações. Este projeto abordará o décimo quadro da Conta Satélite, referente aos indicadores físicos que possibilitam obter uma radiografia geral das principais características do setor (números e tipos de turistas, tipos de transporte utilizados, características dos alojamentos oferecidos, etc).

Para fins de avaliação de seus impactos econômicos, a estrutura da CST está baseada nas relações entre a oferta e a demanda. Nesse sentido, são apresentadas as seguintes definições básicas relativas ao conceito da Demanda e, posteriormente da Oferta. 


\subsection{1 - Conceitos básicos}

Turismo:

conjunto de atividades que as pessoas realizam durante suas viagens e estadas em lugares distintos de seu entorno habitual, por um período de tempo consecutivo inferior a um ano, com fins de ócio, por negócios ou outros motivos.

(ONU, OMT - 1994).

\subsubsection{1 - Demanda}

A) Visitantes:

"indivíduo que se desloca a um lugar distinto de seu entorno habitual por um período de tempo inferior a 12 meses e cuja finalidade principal da viagem não seja efetuar uma atividade remunerada no local visitado"

(OMT -1993)

B) Entorno Habitual:

"corresponde aos limites geográficos dentro dos quais o indivíduo se desloca em sua vida cotidiana, exceto por ócio ou recreação (Condição que exclui as residências secundárias do conceito de entorno habitual, mesmo que ocorram visitas regulares)" (EMBRATUR).

C) Classe de visitantes por duração de viagem:

Turistas - que permanecem uma ou mais noites no local visitado;

Excursionistas - são os visitantes que não pernoitam no local visitado;

Visitantes em transito - que nas CST serão tratados como visitantes.

D) Classe de visitantes por destino:

Turistas Internacionais (visitantes internacionais que pernoitam no local)

Excursionistas Internacionais

Turistas Internos (visitantes internos que pernoitam no local)

Excursionistas Internos

E) Motivação da viagem:

Ócio recreação ou férias

Visita a parentes ou amigos

Negócios ou motivos profissionais (inclui estudos)

Tratamento de saúde

Religião, peregrinação

Outros motivos (visitantes em trânsito, tripulações,...) 
F) Consumo Turístico:

"gasto total de consumo efetuado por um visitante, ou por conta de um visitante, para, durante ou decorrente de sua viagem e estada no lugar de destino"

(OMT).

G) Local do Consumo Turístico: pode-se distinguir sete agregados, a partir do critério do local:

C.T. Interno - efetuado por residentes em seu próprio país;

C.T. Emissor - efetuado por residentes em países diferentes de suas

residências;

C.T. Receptor - efetuado por não residentes no país receptivo;

C.T. Interior - compreende todo o gasto efetuado por residentes e não

residentes no país receptivo;

no país de origem;

C. Interior Turístico - acresce ao C.T. Interior os gastos do C.T. Emissor

independentemente do destino;

C.T. Nacional - compreende todo o consumo de residentes,

C.T. Internacional - compreende todo o C.T. Receptor e o C.T. Emissor.

H) Consumo Coletivo Turístico: compreende o consumo de uma classe de bens/serviços.

I) Unidade de Consumo:

Visitante - a unidade de consumo mais relevante;

Gastos dos residentes na recepção - consumo efetuado por famílias residentes, decorrentes da estada de visitantes; funcionários em serviço;

Unidades produtivas - empresas financiando gastos de viagens de seus

Administração Pública - viagens para tratamento medico, formação profissional e outros dessa natureza;

Resto do mundo - residentes em viagens a outros países, hospedados gratuitamente em residências de parentes e amigos;

\subsubsection{2 - Oferta}

A) Tipos de Bens/Serviços:

Nem todos os bens e serviços do consumo turístico são característicos desta atividade. Com a finalidade de padronizar conceitos a OMT propões:

a) Característicos: aqueles que, sem o Turismo, deixam de existir em quantidade significativa ou seu consumo reduzir-se-ia substancialmente.

b) Conexos: são consumidos pelos visitantes em quantidades significativas, mas não são típicos, muito menos, exclusivos.

c) Específicos: o conjunto de ambos os tipos anteriores. 


\section{3 - Plano Nacional do Turismo (2003 - 2007)}

O Plano Nacional de Turismo está desenvolvido sobre os seguintes Macro Programas:

\subsection{1 - Macro Programa 1: Gestão e Relações Institucionais}

- Programa de acompanhamento do Conselho Nacional de Turismo;

- Programa de Avaliação e Monitoramento do Plano;

- Programa de Relações Internacionais.

\subsection{2 - Macro Programa 2: Fomento}

- Programa de Atração de Investimentos;

- Programa de Financiamento p/ o Turismo.

\subsection{3 - Macro Programa 3: Infra-Estrutura}

- Programa de Desenvolvimento Regional;

- Programa de Acessibilidade Aérea, Terrestre, Marítima e Fluvial.

\subsection{4 - Macro Programa 4: Estruturação e Diversificação da Oferta Turística}

- Programa de Roteiros Integrados;

- Programa de Segmentação.

\subsection{5 - Macro Programa 5: Qualidade do Produto Turístico}

- Programa de Normatização da Atividade Turística;

- Programa de Qualificação Profissional. 


\subsection{6 - Macro Programa 6: Promoção e Apoio a Comercialização}

- Programa de Promoção Nacional e Internacional do Turismo Brasileiro;

- Programa de Reposicionamento da Imagem Brasil;

- Programa de Apoio a Comercialização.

\subsection{7 - Macro Programa 7: Informações Turísticas}

- Programa de Base de Dados;

- Programa de Pesquisa de Demanda;

- Programa de Avaliação de Impactos do Turismo;

- Programa de Avaliação de Oportunidades de Investimentos.

\subsubsection{1 - Descrição do Macro Programa 7:}

A atividade turística depende intensamente de informações que facilitem o seu desenvolvimento.

É necessário um programa contínuo, que não só pesquise a oferta, mas também, a demanda. Um sistema que avalie o impacto da atividade na economia, criando condições para o fortalecimento do setor junto à sociedade.

Os dirigentes públicos e privados necessitam de informações essenciais para tomada de decisão gerencial e para a captação e implementação de novos empreendimentos turísticos.

A produção e disseminação das informações vão proporcionar o aparecimento de uma nova cultura, referencial no setor, baseado em números e pesquisas contínuos e confiáveis, facilitando a profissionalização e otimizando a aplicação dos recursos públicos e privados. 


\subsubsection{2 - Objetivos do Macro Programa 7:}

- Conhecer a oferta turística do mercado nacional;

- Avaliar o impacto da atividade turística na economia;

- Dar suporte as ações de promoção, marketing e apoio à comercialização do produto Brasil;

- Dar suporte à tomada de decisão de dirigentes públicos e privados do turismo;

- Conhecer a demanda do mercado internacional;

- Dar suporte a decisão de potenciais investidores no setor do turismo.

\section{4 - Plano Estadual de Turismo do Estado de Goiás (2003-2007)}

\subsection{1 - Programas:}

O Plano Estadual de Turismo do Estado de Goiás está organizado em programas, tais como:

\subsubsection{1 - Programa Mostra Goiás}

- Promoção e divulgação do Estado de Goiás em âmbito regional, nacional e internacional;

- Fomento e apoio a eventos turísticos;

- Fomento e apoio receptivo ao turismo.

\subsubsection{2 - Programa Infra-Estrutura Turística}

- Elaboração de Estudos e Projetos de Desenvolvimento do Turismo;

- Implantação e implementação da sinalização turística;

- Fomento e Implantação do Memorial do Turismo Goiano;

- Implementação e implementação de Infra-Estrutura Turística no Estado de Goiás; 


\title{
5.4.1.3- Programa de Inteligência Turística
}

- Implantação e implementação do Sistema de Informações Turísticas;

- Fomento e apoio à pesquisa;

- Gestão estratégica de dados e informações.

\subsubsection{4 - Programa de Produto Turístico}

- Regularização e cadastramento dos serviços Turísticos no Estado de Goiás;

- Execução descentralização da AGETUR;

- Desenvolvimento de novos destinos turísticos;

- Implantação, implementação e capacitação em Turismo no Estado de Goiás;

- Desenvolvimento dos pólos turísticos.

\author{
Estratégia "Caminhos de Goiás" \\ Desenvolvimento Sustentável: \\ Camitho do Sol \\ Caminho do Ouro \\ Caminho das Águas \\ Caminho da Biosfera.
}

\subsection{2 - Objetivos do Plano Estadual de Turismo:}

- Divulgar a marca Goiás, nacional e internacionalmente;

- Desenvolver o sistema de informações turísticas, integrado com as universidades e trade turístico;

- Suprir as deficiências de infra-estrutura básica;

- Desenvolver produtos turísticos de qualidade em condições de competir no mercado nacional e internacional. 


\section{CAPÍTULO II}

\section{6 - METODOLOGIA DA PESQUISA}

Para a realização desta monografia foi levantada a importância da pesquisa como produção de conhecimento, tendo caráter científico e didático. "Pesquisa é produzir conhecimento novo, relevante teórica e/ou socialmente". (Luna, 2002).

Para que as pesquisas sejam consideradas produções de conhecimento científico são necessárias à utilização de uma metodologia, que irá direcionar e conduzir a uma reflexão mais crítica sobre o tema escolhido. "Metodologia significa, etimologicamente, o estudo dos caminhos, dos instrumentos usados para se fazer ciência”. (Demo, 1981, pág.07).

"Podemos dizer que toda pesquisa tem uma intencionalidade, que é a de elaborar conhecimentos que possibilitem compreender e transformar a realidade". (Pádua, 1997, pág.30). Sendo assim, este projeto tem a intenção de levantar informações sobre as características e a percepção do turista que visita o município de Pirenópolis, com relação aos serviços turísticos prestados por este Município.

\section{1 - Definição dos métodos de pesquisa}

$\mathrm{O}$ autor do projeto deve indicar a metodologia adequada que venha solucionar o problema da pesquisa. A escolha do método depende do problema a ser investigado, dos objetivos propostos e também, da disponibilidade de recursos.

Segundo Sâmara e Barros (1997) existem três métodos básicos de pesquisa: exploratórias, descritivas e experimentais. 


\subsection{1 - Pesquisa exploratória}

Os estudos exploratórios, também denominados desk research, tem como principal característica à informalidade, a flexibilidade e criatividade, e nele procura-se obter um primeiro contato com a situação a ser pesquisada ou um melhor conhecimento sobre o objeto em estudo levantado, e hipóteses a serem confirmadas. Os estudos exploratórios são realizados a partir de dados secundários (já disponíveis); conversas informais com pessoas especializadas no assunto de interesse e estudo de casos selecionados, em que se incluem também pesquisas já realizadas.

A grande vantagem do estudo exploratório é obter informações a baixo custo, já que possibilita a investigação de informações existentes e de conversas informais, porém sua desvantagem é a possível obsolescência dessas informações, por falta de atualização ou a inexistência de dados fundamentais. Esse fato é relevante no Brasil, onde há dificuldades na obtenção de dados recentes em órgãos oficiais.

\subsection{2 - Pesquisa descritiva}

Os estudos descritivos também chamados pesquisas ad-hoc, como diz o próprio nome procuram descrever situações de mercado a partir de dados primários, obtidos originalmente por meio de entrevistas pessoais ou discussões em grupo, relacionando e confirmando hipóteses levantadas na definição do problema de pesquisa. Os estudos descritivos podem ser qualitativos ou quantitativos.

\subsubsection{1 - Estudos descritivos estatísticos}

Os descritivos estatísticos, ou pesquisa quantitativa busca uma análise das relações de consumo, respondendo à questão "Quanto" para cada objetivo do projeto de pesquisa que tenha adotado esta metodologia. Daí a necessidade de esses estudos serem 
realizados a partir da elaboração de amostras da população, utilizando-se a estatística para este fim, pois o que se espera é extrapolar os resultados na amostra em estudo para determinada população. Os resultados da pesquisa são analisados e interpretados a partir de médias e percentuais das respostas obtidas.

\subsubsection{2 - Estudos descritivos de caso}

O estudo descritivo de caso, ou pesquisa qualitativa, tem como característica principal compreender as relações de consumo "em profundidade". São realizadas a partir de entrevistas individuais ou discussões em grupo, e sua análise verticalizada em relação ao objeto em estudo permitem identificar pontos comuns e distintos presentes na amostra escolhida.

\subsection{3 - Pesquisa experimental ou casual}

Os estudos procuram estabelecer uma relação de causa e efeito entre variáveis em estudo de forma prática. São realizadas a partir da definição de um problema e da formulação de hipóteses sobre resultados possíveis e definição das variáveis que serão manipuladas ou controladas para o estudo.

(Sâmara e Barros, 1997, pág.24)

\subsection{4 - Métodos de coleta de dados}

Os métodos de coleta de dados determinam a maneira como os dados serão obtidos no projeto. Segundo alguns autores existem três métodos mais utilizados em pesquisa: a observação, o inquérito ou contato e o interativo. 


\subsubsection{1 - Método de observação}

A técnica de observação é utilizada quando se pretende levantar hipóteses preliminares sobre o comportamento de consumo.

\subsubsection{2- Método de inquérito ou contato}

Pessoal - é o método de coleta de dados mais largamente utilizado em pesquisa de marketing, pois com ele se obtém o maior número de informações possíveis do entrevistado, embora haja sempre uma caracterização da artificialidade da situação e possível influência do entrevistador sobre o entrevistado.

Telefone - tem a vantagem de ser um meio rápido de obter informações, porém a prática evidencia que há um maior desinteresse por parte dos entrevistados em responder, ocorrendo um maior número de recusas do que na entrevista pessoal.

Correspondência - esse método de coleta de dados pode atingir longas distancias em termos geográficos e de amplitude da amostra, no entanto exige que o questionário a ser respondido seja claro e sintético para não suscitar dúvidas impossíveis de serem resolvidas.

\subsubsection{3 - Método interativo}

Por esse método há a interação entre o consumidor e um computador, que pode estar em um supermercado, por exemplo, ou em residências e empresas; via internet. Neste caso, o microcomputador há um programa que contém um questionário e instruções para que o consumidor digite as respostas a respeito de produtos, serviços, hábitos e atitudes de consumo, etc.

(Sâmara e Barros, 1997,pág. 47). 


\subsection{5 - Elaboração do instrumento para coleta de dados}

No projeto de pesquisa deve constar, como anexo, um modelo do instrumento de coleta de dados que se pretende utilizar. A formulação do instrumento de coleta é feita em função do problema e das variáveis operacionalizadas para a sua solução. Todos os dados levantados devem possuir relação com a questão que se pretende esclarecer.

(Dencker, 2001, pág.89).

Os instrumentos de pesquisa mais utilizados são a entrevista, o questionário e o formulário. Constituem uma lista de indagações formuladas pelo pesquisador para levantar informações desejadas. No questionário, as perguntas são entregues por escrito e os informantes preenchem as respostas; na entrevista, é o pesquisador que faz as perguntas e anota ou grava as respostas; o formulário é utilizado no controle da observação, devendo ser preenchido pelo pesquisador. O questionário aplicado pelo pesquisador é denominado formulário.

Após a definição do problema e dos objetos, dos métodos de pesquisa e de coleta dos dados, deve se elaborar o formulário para coleta de dados, que chamaremos de questionários:

- Questionário Estruturado - quando tem uma seqüência lógica de perguntas que não podem ser modificadas nem conter inserções pelo entrevistador. As perguntas são feitas exatamente como estão escritas no formulário de coleta de dados;

- Questionário Não Estruturado - é usado nas pesquisas qualitativas, denominadas roteiro, em que pode haver inserção de perguntas pelo entrevistador conforme o andamento da entrevista;

- Questionário Não Disfarçado - os objetivos da pesquisa podem estar explícitos no questionário;

- Questionário Disfarçado - os objetivos não ficam claros no questionário.

(Sâmara e Barros, 1997, pág.52). 


\subsection{6 - Tipos de perguntas}

- Perguntas fechadas - são fornecidas as possíveis respostas ao entrevistador, sendo que apenas uma alternativa de resposta é possível.

- Perguntas abertas - nesse tipo de pergunta o entrevistado responde livremente o que pensa sobre o assunto.

- Perguntas semi-aberta - é a junção de uma pergunta fechada a uma aberta em que num primeiro momento, o entrevistado responde a uma das opções de alternativas e depois justifica ou explica a sua resposta.

- Perguntas encadeadas - a segunda pergunta depende da primeira.

\subsection{7 - População (universo)}

População refere-se a todos os membros de determinado tipo de agrupamento que se pretende estudar. Como elemento é o tipo de agrupamento, unidade de amostra é a configuração da melhor representação possível da população que se quer estudar, extensão é a amplitude do que se pretende estudar e tempo é a unidade de duração do evento que se tenciona examinar.

(Cobra, 1992, pág.183)

\subsection{8 - Tabulação}

É a apresentação codificada e padronizada dos dados coletados. Segundo Sâmara e Barros (1997, pág.79) "É a maneira ordenada de dispor os resultados numéricos para que a leitura e a análise sejam facilitadas". E, completa Dencker (2001, pág.91) "Os dados tabulados são descritivos e interpretados pelo pesquisador, que utilizará em sua análise as técnicas adequadas". 


\title{
6.1.9 - Análise dos dados
}

Para Sâmara e Barros (1997, pág.79) a análise dos dados "é a descrição do quadro de tabulação referente aos valores relevantes".

\begin{abstract}
Más, segundo Stablein que escolhe a expressão interpretar dados, em vez de dados ou expressões alternativas como "sumarizar dados". Essa última expressão sugere um processo mecânico de gravar e isto é, um processo em que os dados falam por si mesmos. Isso não faz jus ao esforço e criatividade demandada dos pesquisadores na coleta, análise e relato de dados (Frost e Stableins, 1992; Hackman, 1992; Meyer et alii, 1992). Essa linguagem também esconde o pesquisador em uma névoa de "objetividade" que não é garantida em relatórios de estudos quantitativos ou qualitativos.

(Stablein,Ralph - Dados em Estudos Organizacionais; Apostila CET/UnB, Disciplina 14: Gestão de Pessoas, pág.66)
\end{abstract}

Em se tratando de pesquisas com visitantes em destinos turísticos, podemos ressaltar que é muito difícil a aplicação de métodos de seleção aleatórios, ou probabilísticos, em seleção de amostra representativa, pois os destinos turísticos possuem inúmeros pontos de visitação e de acesso, principalmente em se tratando dos municípios goianos. Sendo alternativa a aplicação de métodos descritivos, não-probabilísticos intencionais ou por conveniência, para tentar aumentar a confiabilidade dos resultados.

Para a execução da pesquisa estão previstas as etapas e condições enumeradas a seguir: 


\section{2 - Perfil, Motivação e Percepção do Visitante:}

Para atingir os objetivos propostos por este trabalho foram realizadas pesquisas exploratórias, onde o caso em estudo é o Município de Pirenópolis / GO.

O método de coleta de dados utilizado foi o contato pessoal, através de questionário estruturado, não disfarçado, com uma pergunta aberta e as demais fechadas (vide Anexo B).

O questionário caracterizará o perfil do visitante em dado momento, a motivação que leva o visitante a procurar a região e a percepção deste, com relação à infra-estrutura, atrativos equipamentos e serviços turísticos.

\subsection{1 - Operacionalização das variáveis}

\subsubsection{1 - Perfil do Visitante:}

- Nome e e-mail (opcional)

- Local de residência;

- Sexo;

- Idade;

- Agrupamento;

- Quantidade de pessoas no agrupamento;

- Meio de transporte;

- Gasto médio / dia;

- Quantas pessoas estão incluídas no gasto;

- Local de hospedagem;

- Local de trabalho;

- Renda pessoal;

- Escolaridade; 
- Tempo de permanência;

- Atividades desenvolvidas;

- Já visitou o município;

- Pretende voltar ao município.

\subsubsection{2 - Motivação do Visitante:}

- Motivo da viagem;

- Indução da viagem.

\subsubsection{3 - Percepção do Visitante quanto a:}

- Avaliação da infra-estrutura (acessos ao município, limpeza urbana, sinalização nas rodovias, sinalização dentro do município, aparência da cidade, telefone público, telefone celular, serviços de transporte de uso público, iluminação pública, latões de lixo, segurança, e serviços médicos / hospitalares);

- Avaliação dos atrativos turísticos (acesso aos atrativos, infra-estrutura dos atrativos, patrimônio histórico, matas, rios/cachoeiras/lagos, monumentos, festividades, cavernas/grutas/serras/morros, limpeza dos atrativos, sinalização até os atrativos e sinalização dentro dos atrativos);

- Avaliação dos equipamentos e serviços turísticos (hospedagem, alimentação, informações, hospitalidade, atendimento, entretenimentos, e preços);

- Presença de guias de turismo na região;

- Em caso afirmativo, utilizou seus serviços;

- Avaliação dos serviços de guias. 


\subsection{2 - Amostra}

etapas:

Os trabalhos referentes ao levantamento de dados foram divididos em quatro

Semana Santa (16 a 21 de abril):

- Foram aplicados 397 questionário visitantes

Final de semana comum (16 a 18 de maio):

- Foram aplicados 112 questionários visitantes

Festa do Divino - Cavalhadas (08 a 09 de junho):

- Foram aplicados 148 questionários visitantes

Férias de Julho (11 a 17 de julho):

- Foram aplicados 322 questionários visitantes

- Total de 979 questionários aplicados visitantes.

\subsection{3 - Instrumento de coleta de dados}

A pesquisa foi realizada mediante aplicação de questionário estruturado, não disfarçado, com uma pergunta aberta e as demais fechadas (vide Anexo B). Estes questionários foram aplicados por pesquisadores que são estudantes de turismo das Instituições de Ensino Superior da cidade de Goiânia.

Foram realizados treinamentos com os pesquisadores, que passaram a integrar o programa e compreender o objetivo de tal pesquisa. 
O questionário sofreu alteração ao longo das etapas para atender melhor os propósitos da pesquisa. Foram acrescentadas e retiradas questões com a intenção de melhorar tal instrumento, na tentativa de torna-lo mais preciso.

\subsection{4 - Procedimentos de coleta de dados}

- Aplicação de questionários com o visitante em atrativos, hotéis, restaurantes, casas de veraneio (aluguel) e outros pontos pré-selecionados;

- A utilização de método de organização de "conglomerados ou grupos" dos pontos de coleta por características comuns foi aleatória (ex. tipos de atrativos, faixa de preços de hotéis, tipos de restaurantes, supermercado, pontos de visitação históricos na cidade, estacionamento de ônibus de turismo, etc.);

- A seleção aleatória de "n" pontos por grupo, sendo escolhidos os pontos de maior fluxo de visitantes - dependendo do horário e da quantidade;

- Seleção sistemática da amostra (um visitante pesquisado a cada "n" visitantes existentes).

\subsection{5 - Locais e periodicidade de aplicação dos questionários:}

Os turistas foram abordados em restaurantes, pizzarias e bares, hotéis e pousadas, lojas de artesanato, CAT (Centro de Atendimento ao Turista), em pontos turísticos dentro e fora da cidade (praças, igrejas, cachoeiras, parques, trilhas):

As pesquisas foram realizadas em vários horários, iniciando às $9 \mathrm{~h}$ e terminando no máximo às $23 \mathrm{~h}$, com intervalos para o almoço, lanche e jantar. Dependendo do fluxo de visitantes eram distribuídas equipes nos pontos mais visitados. 
- Rua do Lazer, Rua do Rosário, Rua Beira Rio, Rua Direita, Ponte Rio das Almas, Praça do Coreto, Lojas de artesanato, Fazenda Babilônia, Rodoviária : os visitantes foram abordados nos períodos da manhã, da tarde e da noite , pois eram os horários e locais de maior movimentação de turistas na cidade;

- Cachoeiras Andorinha, Bom Sucesso, Amor e Vagafogo: os visitantes foram abordados nos períodos da manhã e da tarde pois eram os horários de maior visitação;

- CAT : os visitantes foram abordados nos períodos da manhã e da tarde devido ao horário de funcionamento e grande visitação.

\section{3 - Cronograma de Atividades}

\begin{tabular}{|l|c|c|c|c|c|c|c|c|c|}
\hline \multirow{2}{*}{\multicolumn{1}{c|}{ Atividades }} & \multicolumn{7}{c|}{ Ano 2003/Mês } \\
\cline { 2 - 11 } & Fev & Mar & Abr & Mai & Jun & Jul & $\begin{array}{c}\text { Ago } \\
\text { Set }\end{array}$ & Out & $\begin{array}{c}\text { Nov } \\
\text { Dez }\end{array}$ \\
\hline Planejamento para monografia & $\mathrm{X}$ & $\mathrm{X}$ & $\mathrm{X}$ & $\mathrm{X}$ & & & & & \\
\hline Elaboração do Projeto & & & & & $\mathrm{X}$ & & & & \\
\hline Contatos com os municípios & & & $\mathrm{X}$ & $\mathrm{X}$ & $\mathrm{X}$ & & & & \\
\hline Coleta dos dados - pesquisas & & & $\mathrm{X}$ & $\mathrm{X}$ & $\mathrm{X}$ & $\mathrm{X}$ & & & \\
\hline Tabulação e análise dos dados & & & & $\mathrm{X}$ & $\mathrm{X}$ & & $\mathrm{X}$ & $\mathrm{X}$ & $\mathrm{X}$ \\
\hline Elaboração da monografia & & & & & $\mathrm{X}$ & $\mathrm{X}$ & $\mathrm{X}$ & $\mathrm{X}$ & $\mathrm{X}$ \\
\hline Entrega da monografia & & & & & & & & & $\mathrm{X}$ \\
\hline
\end{tabular}




\section{CAPÍTULO III}

\section{7 - CONHECENDO PIRENÓPOLIS}

\section{1 - Histórico do Município:}

Aparentemente, existem duas versões para o surgimento de Pirenópolis: uma, constante do livro Levantamento Histórico e Econômico dos Municípios Goianos, $3^{\text {a }}$ Edição 1973, que diz: "O povoado de Meia Ponte surgiu com a chegada, em outubro de 1727, da bandeira chefiada por Manoel Rodrigues Tomar, companheiro de Bartolomeu Bueno da Silva, o filho que o mandou a descobrir novos garimpos. A povoação tomou nome de Minas de Nossa Senhora do Rosário de Meia Ponte, lembrando o santo do dia que ali chegaram e, conforme a tradição, por haverem eles construído sobre o rio das Almas, que banha a cidade, uma ponte, cuja metade foi levada pelas águas de uma enchente". Uma segunda versão, apresentada no livro História da Terra e do Homem do Planalto Central, do historiador Paulo Bertran, diz: "Se Americano do Brasil não estiver errado na data de 1729 como a da descoberta de Santa Cruz por Manoel Dias da Silva, a próxima bandeira a sair sob o patrocínio de Anhanguera é a expedição conduzida por Urbano do Couto Menezes que financiada por Manoel Rodrigues Tomar ao Planalto Central, da qual resultará a descoberta das minas de Meia Ponte, em 1730, e a fundação de Pirenópolis, em 1731”.

Sobre o nome de Meia Ponte também há duas versões para a sua origem. Segundo o geógrafo brigadeiro Cunha Mattos e Luiz D’Alincurt, o nome vem de uma pedra que se projetou sobre o rio com forma de meio-arco de ponte. Teria sido sobre essa pedra que se lançaram os paus para a passagem dos primeiros povoadores. Outra versão sugere que os primitivos moradores do arraial construíram sobre o rio das Almas uma ponte feita com duas peças de madeira e uma delas foi levada pela correnteza, ficando o nome de Meia Ponte para o povoado. 
Pirenópolis foi um dos primeiros povoamentos do Planalto Central que, como ocorreu com outros povoamentos da época, teve desenvolvimento até fins do século XVIII calcado na mineração. Auguste de Saint-Hilaire, quando de sua passagem por aqui em 1819, deixou o seguinte registro: "O lugar, onde atualmente está situada a povoação de Meia Ponte, foi descoberta, em 1731, por um tal Manoel Rodrigues Tomar. Os primeiros que ali se estabeleceram forma exploradores de ouro, que queriam extrai-lo das margens do Rio das Almas. Todavia, como a povoação que lhes construíram se acha situada na junção das principais estradas da província, e que por lá passava outrora grande número de caravanas, seus habitantes, certos de venderem vantajosamente os produtos do solo, renunciaram logo às lavagens, de que hoje não se vêem senão fracos vestígios, e foram, ao que parece, os primeiros de toda a capitania que tiveram a glória de se ocuparem do cultivo das terras. Os bosques, comuns nos arredores da povoação, favoreceram o trabalho dos agricultores, e essas capoeiras, atualmente abandonadas, tomaram o lugar do feijão e do milho dos antigos colonos".

O Fato de Pirenópolis situar-se numa região de junção das principais estradas da província no século XVIII propiciou a que diversos viajantes, políticos, naturalistas e cientistas que por elas transitavam, fizessem de Pirenópolis local de parada, deixando suas impressões através de textos e desenhos, alguns registrando a natureza e os costumes goianos.

Em 1892, quando da realização dos estudos para a transferência da Capital brasileira para o Planalto Central, uma comitiva da Comissão Cruls, comandada pelo Dr. Ernesto Ule, hospedou-se em Pirenópolis enquanto fazia o levantamento da região, aferindo pela primeira vez a altitude do Pico dos Pireneus: 1.385 metros do nível do mar.

Pirenópolis teve sua evolução urbana a partir do rio das Almas. O início do povoado ocorreu somente na margem esquerda do rio, a partir da concessão de datas minerais aos mineradores, que as obtinha conforme o número de escravos de que dispunham. As terras situadas à margem direita não foram parceladas inicialmente, pois pertencia a um único proprietário, dono de muitos escravos. 
Consta que a primeira rua a surgir em Pirenópolis foi à rua das Bestas, atual rua Direita, ao largo da Igreja Matriz de Nossa Senhora do Rosário, esta construída entre 1732 e 1736. A expansão urbana ocorreu em padrão radial, a partir da Igreja, e nos anos 1750 já se configurava o perímetro urbano, sendo seus extremos delimitados por outras Igrejas, algumas ainda em construção.

A cidade viveu momentos de dinamismo e estagnação. O período entre $1750 \mathrm{e}$ 1800 foi marcado pela decadência da mineração. A partir de 1800, a economia foi reativada com base em culturas diversificadas, principalmente a de algodão, fortalecendo, também, sua função de entreposto de âmbito regional. A estrutura urbana quase não se alterou, tendo ocorrido, porém, uma renovação arquitetônica em seus prédios.

Com a construção de novas estradas e a conseqüente alteração das antigas rotas comerciais na segunda metade do século XIX, o comércio de Meia Ponte perdeu importância no contexto regional e vê-se, novamente, na estagnação. Esse isolamento só veio a romper nos anos 1970, principalmente pela influencia de Brasília a apenas $150 \mathrm{~km}$ de distancia. Já em 1988 Pirenópolis recebe um premio pela sua importância arquitetônica, a cidade é tombada pelo Patrimônio Histórico Nacional.

A partir desse momento a cidade se expandiu com relativa rapidez, sendo significativo o numero de pessoas que, vindas de Goiânia e Brasília, principalmente, adquiriram imóveis e fez da cidade seu lugar de descanso e harmonia nos finais de semana.

Muitos foram, também, as pessoas que optaram por viver em Pirenópolis a partir do final da década de 70, principalmente em comunidades alternativas. O grupo Terra Nostra, de artesãos da prata, organizou-se em comunidade com proposta de auto-gestão e instalou na cidade um ateliê onde desenvolveu o artesanato, é conhecido em boa parte do Brasil e também no exterior. Outras comunidades se formaram, com a Frater, a Omni e a Nirvana, todas com propostas preservacionistas, e se instalaram nas imediações da cidade, rumo a Serra dos Pirineus. 
Cabe ressaltar a condição de Pirenópolis como "Berço da Imprensa Goiana", pois ai foi impresso o primeiro jornal de Goiás, o "Matutina Meiapontense", que circulou de 1830 a 1834. É, também, nesta cidade que desde 1819 ocorre à famosa Festa do Divino Espírito Santo, a mais tradicional festa do município, ocasião em que se realizam as Cavalhadas simbolizando os combates entre Mouros e Cristãos.

$\mathrm{Na}$ década de 90 ocorreu uma série de iniciativas individuais voltadas para o turismo, transformando a cidade que até então tinha sua economia baseada na agropecuária e na comercialização de pedras. Em poucos anos multiplicaram-se as pousadas, os restaurantes, os ateliês, os serviços em geral, e os atrativos naturais passam a se estruturar para receber o turista. Culmina o século XX com uma série de investimentos públicos na restauração de prédios históricos, revigorando em Pirenópolis o seu caráter bucólico.

(Fonte: Inventário e Diagnóstico Turístico do Município de Pirenópolis. Ano 2001).

\section{2 - Infra-Estrutura Urbana:}

Água - o abastecimentos é feito pela SANEAGO (Saneamento de Goiás S/A), que atende aproximadamente $90 \%$ da cidade com água tratada.

Lixo - coleta de 100\% pela Prefeitura Municipal e destino em aterro sanitário.

Esgoto - destino de $80 \%$ em fossa, 10\% tratados e 10\% a céu aberto, diretamente no rio das Almas.

Telecomunicações - Convencional e Celular.

Segurança - Policia Militar, Policia Civil e Bombeiros.

Vias urbanas - as ruas em sua maioria possuem pavimentação com pedras de Pirenópolis.

Transporte: conta com um terminal rodoviário com capacidade para embarque e desembarque simultâneo de 07 ônibus. Próximo à cidade, a cerca de $2 \mathrm{~km}$, há uma pista de pouso pavimentada, para aviões de pequeno e médio porte. Há, também, um heliporto particular, na Posada dos Pireneus.

(Fonte: Inventário e Diagnóstico Turístico do Município de Pirenópolis. Ano 2001). 


\section{3 - Áreas de preservação:}

Parque Estadual dos Pireneus - com área de 2.833,26 hectares, perímetro de 28.118,60 metros, situado entre os paralelos $15^{\circ} 46^{\prime} 45$ “e 1550'08”, e os meridianos $48^{\circ} 48^{\prime} 30$ "e 48 53'10”, atingindo os municípios de Pirenópolis, Cocalzinho e uma pequena parcela do município de Corumbá. Encerra em sua área as nascentes do rio das Almas e rio Corumbá, e tem como ponto culminante o Pico dos Pireneus, o ponto mais lato da região.

RPPNs - existem no município cinco, já homologadas pelo IBAMA (Instituto Brasileiro do Meio Ambiente), que totalizam a área de 1.315,51 hectares, quais sejam:

- Santuário de Vida Silvestre Vagafogo;

- Fazenda Arruda;

- Fazenda Gleba Vargem Grande I;

- Santuário de Vida Silvestre Flor das Águas;

- Reserva Santuário de Gabriel.

APA Pireneus - Área de Proteção Ambiental, criada para proteger a região serrana e o entrono do Parque Estadual dos Pireneus, abrangendo os municípios de Pirenópolis, Corumbá e Cocalzinho, com aproximadamente 22.00 hectares e perímetro de 73.400 metros.

(Fonte: Inventário e Diagnóstico Turístico do Município de Pirenópolis. Ano 2001).

\section{4 - Caracterização (Arquitetura, Cultura e Conservação):}

Como foi dito anteriormente, a historia de Pirenópolis começou a ser registrada a partir de 1727, quando da chegada dos bandeirantes. De acordo com a descrição de viajantes, no inicio do século XIX Pirenópolis era um arraial que contava com aproximadamente 300 casas, algumas delas boas, oito ruas, travessas, becos, praças, chafarizes, uma fonte, 5 igrejas, uma Casa de Câmera e Cadeia construídas segundo o modelo português. 
Muitas dessas construções foram demolidas, outras alteradas, mas pode-se dizer que a cidade mantém suas características arquitetônicas coloniais, cujo estado de conservação é bom, graças ao empenho dos proprietários. Devido a essa característica, Pirenópolis foi tombada pelo Patrimônio Histórico Nacional.

Nos últimos anos, graças ao empenho de moradores da cidade em buscar patrocínio para a restauração do patrimônio histórico, foram restaurados inúmeros monumentos (igrejas, teatro, cinema, ponte). Más, infelizmente em 2002, devido um incêndio ocorrido na Matriz de Nossa Senhora do Rosário, todos os esforços estão voltados para a restauração desta igreja, que é um marco da religiosidade e arquitetura do Município.

Sua arquitetura colonial testemunha a influencia portuguesa através de diversas edificações espalhadas pela cidade, entre elas:

- Matriz de Nossa Senhora do Rosário - construída entre 1732 e 1736. É um dos mais antigos monumentos sacros do estado e o único que resistia em sua forma original desde o tempo dos bandeirantes.

- Igreja Nossa Senhora do Bonfim - construída entre os anos 1750 e 1754. Em 1755, o Sarjento-Mór Antonio José dos Campos fez vir de Salvador à imagem de Nossa Senhora do Bonfim, que ali se encontra até hoje. A igreja mantém seu estilo original apesar de ter sido alterado entre os anos 1887 e 1907, quando suas fachadas coloniais receberam influencias de um estilo neogótico.

- Casa de Câmera e Cadeia - construída nos anos 1916 a 1919, é copia da antiga Casa de Câmera e Cadeia que se localizava no Largo da Matriz, construída em 1733 e posteriormente demolida. Foi o primeiro prédio dente estilo construído em Goiás.

- Theatro de Pyrenópolis - construído em 1889 com a cooperação da comunidade, tendo sua fase áurea no inicio do século. Entre 1947 e 1982, funcionava como cinema, depois serraria e mais tarde como fábrica de móveis, voltando a comunidade após sua restauração, em 1982.

- Igreja Nossa Senhora do Carmo - edificado no ano de 1750, de construção modesta e menos que outras. Mantém seu estilo primitivo, apesar de reformas 
que alteraram temporariamente sua fachada. Hoje funciona ali o Museu de Arte Sacra que conta em seu acervo com os restos da extinta Igreja Nossa Senhora dos Pretos.

Na zona rural, são significativos os seguintes atrativos históricos:

- Fazenda Babilônia - Casa de Engenho construída em 1800, tombada pelo Patrimônio Histórico Nacional. Abrigaram em sua senzala cerca de 200 escravos com suas famílias.

- Fazenda Caiçara - antiga fazenda onde se pode ver um engenho com seus diversos ambientes, ainda em funcionamento.

- Recanto da Mata - Lavras de Ouro - lavras do século XVIII, intocadas desde aquela época.

- Cidade de Pedra - sede da Companhia Goyana de Mineração, construída no ano de 1880, restando vestígios desta época.

(Fonte: Inventário e Diagnóstico Turístico do Município de Pirenópolis. Ano 2001).

\section{5 - Manifestações culturais:}

O município de Pirenópolis possui extraordinárias riquezas em atrativos culturais, muitas provenientes das tradicionais festas religiosas, mesclando com elementos profanos, que dão originalidade aos eventos. As festas mais tradicionais são a Festa do Divino Espírito Santo e a Festa dos Pireneus.

A Festa do Divino teve sua primeira manifestação no Estado de Goiás em Pirenópolis, ainda Meia Ponte, no ano de 1819. É uma festa que dura doze dias e culmina com as Cavalhadas, que iniciam do Domingo de Pentecostes e duram três dias. É uma festa que tem trazido pessoas de todo o Brasil e de diversas partes do mundo, dada a riqueza do seu folclore e das tradições fielmente mantidas. 
A Festa dos Pireneus é realizada na noite de lua cheia de julho. Uma procissão sai da cidade, levando a imagem da Trindade, e dirige-se à capela situada no pico mais lato dos Pireneus, onde é realizada uma missa. A festa acontece no sopé do morro, onde a cidade acampa e se diverte com musica e bebida.

O Calendário de Festas contemplam todo o município, acontecendo praticamente em todo o ano:

- Festa do Ano ( $1^{\circ}$ dia do ano) - é uma festa tradicional na cidade, constituindose de uma missa festiva na Igreja do Bomfim, leilão de prendas da região, etc. Ocorre há mais de 100 anos e atrai um publico regional. Não atrai turista.

- Festa de São Sebastião (20 de janeiro) - festa religiosa, com novena, procissão e leilão. Tem mais de 200 anos de tradição, e atrai um publico regional.

- Carnaval - antigamente havia carnaval de rua, com blocos e bailes em clubes. Há mais de 20 anos deixou de existir, mas nos últimos anos tem saído às ruas o Bloco Urgente Reciclar, resultado do projeto homônimo, que tem como objetivo de conscientizar a comunidade sobre o acumulo de lixo. Atrai um publico de baixo poder aquisitivo.

- Semana Santa - um dos principais feriados sob o ponto de vista do turismo. A cidade recebe, inúmeros visitantes vindos de todas as partes do Estado, Distrito Federal e outras regiões do país.

- Corpus Christi (data móvel) - é outro feriado importante sob o ponto de vista turístico e religioso, pois é um feriado prolongado que atrai inúmeros visitantes.

- Festa do Divino (data móvel) - acontece todo ano, desde 1826, 50 dias após o Domingo de Páscoa. Durante os sete dias que antecedem a Festa, se desenvolve a Folia na Roça. Atrai um público regional, más é crescente o número de turistas.

- Festa de São João (24 de junho) - pequeno movimento isolado nas fazendas com bebida e comida típicas desta data. Publico local.

- Festa do Divino Pai Eteno de Caxambu (data móvel) - ocorre em junho, há mais de 50 anos, tendo como atração principal o desfile de carros de boi. Atrai público regional. Caxambu é um povoado distante $25 \mathrm{~km}$ de Pirenópolis. 
- Festa do Morro (data móvel) - ocorre na lua cheia de julho, no Pico dos Pireneus, com procissão, missa e piquenique ao luar. Público jovem regional.

- Festa do Divino em Lagolândia (data móvel) - acontece no $3^{\circ}$ domingo de julho, durante 2 dias, a $25 \mathrm{~km}$ da cidade. Reúne um público local e alguns turistas de outras localidades.

- Festa da Capela (26 de julho) - com novena, romaria e acampamento. Chega a durar 12 dias.

- Festa da Placa (data móvel) - em agosto. É religiosa, atrai público regional. O povoado de Placa fica a $20 \mathrm{~km}$ da cidade.

- Festa Nossa Senhora do Bonfim (data móvel) em setembro. É uma festa com tradição de mais de 200 anos. Atrai público regional.

- Exposição Agropecuária (data móvel) - em setembro. Reúne publico regional.

- Aniversário da cidade (7 de outubro).

Outro atrativo cultural de Pirenópolis é a culinária goiana, tanto pelas comidas regionais constantes dos cardápios de diversos restaurantes da cidade, como pela qualidade de seus quitutes. Os frutos do cerrado estão sendo utilizados por diversos quituteiros da região, em forma de conservas, doces cristalizados, geléias, licores, etc. Más, também, existem restaurantes com comidas de outras regiões do país e do mundo.

Além deste rico calendário festivo e gastronômico, vêm ocorrendo inúmeras exposições de obras de arte, lançamento de livros, concertos, teatro, shows, festivais e muitas outras manifestações de caráter cultural.

Pirenópolis, também, se destaca no cinema, já foi cenário de quatro longasmetragens, três curta, uma minissérie e uma novela da Rede Globo.

(Fonte: Inventário e Diagnóstico Turístico do Município de Pirenópolis. Ano 2001). 


\section{6 - Artesanato:}

O artesanato em Pirenópolis é bastante diversificado, envolvendo um universo de mais de 300 artesãos que expõem seus produtos nas lojas e ateliês da cidade. A prata e bastante utilizada, sendo um dos principais produtos da economia artesanal.

Os moveis artesanais também, são uma referencia. São inúmeros artesãos e designers que expõem seus produtos, atraindo pela beleza e qualidade reconhecidas nacional e internacionalmente.

\section{7 - Guias locais:}

O guia é parte fundamental para atrair os visitantes e desenvolver o turismo no município, pois existem variados atrativos naturais, históricos e culturais que somente eles sabem e poderão dar as informações corretas.

São pessoas da comunidade que, através de treinamento especializado conduzem visitantes aos principais atrativos turísticos e aos serviços que a cidade oferece. Os guias são qualificados e garantem a preservação dos diferentes ambientes que ali se encontra.

Muitos atrativos exigem a presença do guia, pois são de difícil acesso e a presença dos mesmos, garante a segurança e integridade do visitante, bem como do espaço e da cultura local. 


\section{CAPÍTULO IV}

\section{8 - ANÁLISE DOS DADOS DO LEVANTAMENTO}

\section{1 - Tabulação}

A tabulação dos dados coletados foi realizada na AGETUR, ao longo dos meses de maio, junho, agosto, setembro e outubro. Os dados formam tabulados, parte manualmente e em programa Excel.

Através de escalas de trabalho, foi realizada a tabulação pelos próprios pesquisadores, sempre em duplas: um fazia a leitura o outro digitava. Os questionários foram contados e separados por dia e hora de aplicação. Tal procedimento garante a diminuição de erros e agilidade no processo.

\section{2- Análise dos GRÁFICOS}

\subsection{1 - Semana Santa}

1. Características pessoais

A maior presença foi constituída por indivíduos do sexo masculino $(52,14 \%)$, provenientes do Distrito Federal (49,24\%). Perfazendo 48,23\% de Brasília e 1,01\% de cidades satélite; de Goiânia (29,80\%), do Interior de Goiás (8,59\%) e de outros estados $(12,37 \%)$ Bahia, Espírito Santo, Mato Grosso, Maranhão, Minas Gerais, Paraíba, Paraná, Pernambuco, Piauí, Rio de Janeiro, Roraima, Rio Grande do Sul, Sergipe e São Paulo -, com faixa etária 
entre 20 e 29 anos (44,33\%), com escolaridade em nível superior (64,48\%), destacando funcionários de empresas privadas $(24,43 \%)$.

2. Características econômicas

Evidenciou-se que a renda pessoal foi entre R\$1001,00 e R\$2000,00 (23,17\%). Os visitantes do Distrito Federal gastaram em média R\$ 50,09 por dia e de outros estados (Bahia, Espírito Santo, Mato Grosso, Maranhão, Minas Gerais, Paraíba, Paraná, Pernambuco, Piauí, Rio de Janeiro, Roraima, Rio Grande do Sul, Sergipe e São Paulo) R\$ 66,94.

3. Características do agrupamento

Predominou o deslocamento em grupos familiares $(55,42 \%)$, com permanência média de 4 dias $(34,01 \%)$.

4. Características da viagem

A maior parcela dos visitantes hospedou em hotéis/pousadas/apart-hotel $(48,61 \%)$ e desenvolveu atividades referentes a tomar banho em ambiente natural (71,28\%), relaxar/descansar $(63,48 \%)$ e caminhar $(55,42 \%)$, nesta questão o entrevistado pode escolher mais de uma variável. O meio de transporte mais utilizado foi o carro $(89,67 \%)$.

5. Características motivacionais

A maioria deslocou-se a turismo $(94,71 \%)$. A forma de indução da viagem foi através de informações de parentes e amigos (76,83\%). 


\section{Características perceptórias}

A percepção dos visitantes foi avaliada de acordo com a infra-estrutura, os atrativos e os equipamentos e serviços turísticos da cidade, sendo considerados ótimos, bons, regulares, ruins ou péssimos.

A infra-estrutura foi avaliada como boa: acessos à região (46,97\%), acessos aos atrativos $(39,14 \%)$, infra-estrutura da cidade $(52,02 \%)$, limpeza urbana $(51,01 \%)$, sinalização nas rodovias (36,11\%), aparência da cidade $(42,42 \%)$, iluminação pública $(38,38 \%)$, segurança $(48,74 \%)$ e serviços médico/hospitalares $(10,35 \%)$. E, foi avaliada como regular: latões de lixo $(29,29 \%)$.

Os atrativos foram avaliados como bons: qualidade ambiental dos atrativos visitados (47,47\%), infra-estrutura dos atrativos (41,67\%), patrimônio histórico (46,21\%), diversidade de programas/produtos $(36,62 \%)$, limpeza dos atrativos $(45,45 \%)$ e sinalização nos atrativos $(29,04 \%)$.

Os equipamentos e serviços turísticos da cidade foram avaliados como bons: hospedagem (40,40\%), alimentação (47,47\%), informações $(42,17 \%)$, hospitalidade $(40,91 \%)$, atendimento $(46,46 \%)$, entretenimentos $(36,87 \%)$. Foi avaliado como regular: preços $(29,80 \%)$.

A maioria dos visitantes entrevistados não encontrou guia na região $(76,32 \%)$. Os que encontraram, $46,59 \%$ utilizou os seus serviços e destes, $39,02 \%$ consideraram os serviços como bom. 


\subsection{2 - Final de Semana Comum}

1. Características pessoais

A maior presença foi constituída por indivíduos do sexo feminino $(56,70 \%)$, oriundos do Distrito Federal (50,89\%), de Goiânia (23,21\%), do interior de Goiás $(9,82 \%)$ e de outros Estados (14,29\%), com faixa etária entre 20 e 29 anos $(33,93 \%)$ e destaque para curso superior $(68,75 \%)$.

2. Características econômicas

Evidenciou-se que a maioria dos visitantes possui renda acima de $\mathrm{R} \$ 4.000,00$ (25\%). O gasto médio diário dos visitantes foi destacado por pessoas de outros Países (R\$ $150,00)$.

3. Características do agrupamento

Predominou o deslocamento com amigos $(33,04 \%)$, com permanência de dois dias $(50 \%)$.

4. Características da viagem

Os dados revelam que a maior parcela hospedou em hotel/pousada/apart-hotel $(59,82 \%)$, viajando de carro $(77,68 \%)$ e as principais atividades desenvolvidas foram relaxar/descansar $(45,54 \%)$, caminhar e rios/cachoeiras/lagos $(43,75 \%)$, apreciar a natureza $(29,46 \%)$, importante ressaltar que o entrevistado pode escolher mais de uma variável. Já visitou antes o município (60,71\%) e pretende voltar (97,32\%). 


\section{Características motivacionais}

A maioria deslocou-se a turismo no município $(81,25 \%)$. A forma de indução da viagem foi através de parentes/amigos $(33,04 \%)$.

6. Características perceptórias

Em relação à infra-estrutura do município, foram consideradas boas : o acesso ao município (58,03\%), sinalização nas rodovias (32,14\%), sinalização dentro do município $(34,82 \%)$, aparência da cidade $(44,65 \%)$, limpeza urbana $(53,57 \%)$, iluminação pública (35,71\%), telefone público $(15,18 \%)$, telefone celular $(38,39 \%)$, serviços de transporte de uso público $(4,46 \%)$ e segurança $(43,75 \%)$. Foi avaliado como regular: latões de lixo $(19,64 \%)$, serviços médicos / hospitalares $(11,61 \%)$.

Sobre os atrativos, os turistas consideraram como ótimos: rios/cachoeiras/lagos (27,68\%), cavernas/grutas/serras/morros $(7,14 \%)$.

Considerados bons: acesso aos atrativos $(40,18 \%)$, infra-estrutura dos atrativos $(33,04 \%)$, sinalização até os atrativos $(23,21 \%)$, sinalização dentro dos atrativos $(22,32 \%)$, limpeza (37,50\%), patrimônio histórico $(39,29 \%)$, matas $(31,25 \%)$, monumentos $(21,43 \%)$.

Sobre os equipamentos e serviços turísticos, os turistas consideraram como bons: hospedagem, alimentação e informações $(39,29 \%)$, atendimento $(55,36 \%)$ e entretenimentos $(43,75 \%)$. A hospitalidade foi avaliada como ótima $(55,36 \%)$ e os preços como regulares $(33,93 \%)$.

Dos visitantes entrevistados, 59,82\% não encontrou guia na região; dos que encontraram, $48,72 \%$ utilizou-se de seus serviços e $68,42 \%$ os consideraram como ótimos. 


\subsection{3 - Festa do Divino - Cavalhadas}

1. Características pessoais

A maior presença foi constituída por indivíduos do sexo masculino $(53,71 \%)$, oriundos de Goiânia (31,76\%), do Distrito Federal (30,41\%), de Anápolis (16,89\%), de outros estados $(14,19 \%)$, do interior de Goiás (4,73\%) com faixa etária entre 20 e 29 anos $(35,81 \%)$ e destaque para curso superior $(62,84 \%)$.

2. Características econômicas

A maioria dos visitantes possui renda entre $\mathrm{R} \$ 1.001,00$ e $\mathrm{R} \$ 2.000,00$ (21,62\%). O gasto médio diário dos turistas foi destacado por pessoas do Distrito Federal (R\$110,69).

3. Características do agrupamento

Predominou o deslocamento com a família $(35,81 \%)$ seguido com permanência de mais de dois dias $(44,59 \%)$.

4. Características da viagem

Os dados revelam que a maior parcela hospedou-se em hotel/pousada/apart-hotel $(37,16 \%)$, viajando de carro $(78,38 \%)$, e as principais atividades desenvolvidas foram visitar rios/cachoeiras/lagos (55,41\%), relaxar/descansar (50,68\%), caminhar $(42,57 \%)$, e apreciar a natureza (25\%). Já visitou antes o município (75\%) e pretende voltar $(85,81 \%)$. 


\section{Características motivacionais}

A maioria deslocou-se a turismo no município $(88,51 \%)$. A forma de indução da viagem foi através de parentes e amigos $(66,22 \%)$.

\section{Características perceptórias}

Em relação à infra-estrutura do município, foram consideradas boas : acesso ao município (56,76\%), sinalização nas rodovias $(31,08 \%)$, sinalização dentro do município $(34,46 \%)$, aparência da cidade $(40,54 \%)$, limpeza urbana $(50,68 \%)$, iluminação pública (37,16\%), telefone público (21,62\%), telefone celular $(29,73 \%)$, serviços de transporte de uso público (6,08\%), segurança $(49,32 \%)$ e serviços médicos/hospitalares $(6,08 \%)$. E considerados como regular latões de lixo (25\%). Havendo igualdade de opinião: a aparência da cidade ótima $(40,54 \%)$ e serviços médicos/hospitalares - regular $(6,08 \%)$.

Sobre os atrativos, os turistas consideraram como ótimos: rios, cachoeiras e lagos $(27,03 \%)$ e cavernas, grutas, serras e morros $(14,19 \%)$.

Considerado como bons: acesso aos atrativos (37,84\%), infra-estrutura dos atrativos $(36,49 \%)$, sinalização dentro dos atrativos $(16,22 \%)$, limpeza $(27,03 \%)$, patrimônio histórico $(32,43 \%)$, matas $(20,95 \%)$, monumentos $(25,68 \%)$, festividades $(27,70 \%)$. E considerado como regular a sinalização até os atrativos (17,57\%).

Sobre os equipamentos e serviços turísticos, os turistas consideraram como bons: hospedagem (26,35\%), alimentação (44,59\%), informações $(46,62 \%)$, atendimento $(42,57 \%)$, entretenimentos (40,54\%). A hospitalidade foi avaliada como ótima (42,57\%) e os preços como regular $(38,51 \%)$.

Dos turistas entrevistados, 53,38\% não encontraram guia na região; os que encontraram $47,62 \%$ utilizaram seus serviços e $55 \%$ considerou-o bom. 


\subsection{4 - Férias Julho}

\section{Características pessoais}

A maior presença foi constituída por indivíduos do sexo feminino $(53,45 \%)$, oriundos do Distrito Federal (39,47\%), de Goiânia (25,00\%), de outros estados (12,17\%) e São Paulo (12,17\%) e do interior de Goiás (9,21\%) com faixa etária entre 20 e 29 anos $(31,91 \%)$, e destaque para curso superior $(53,29 \%)$.

2. Características econômicas

Evidenciou-se que a maioria dos visitantes possui renda entre $\mathrm{R} \$ 1.001,00 \mathrm{e}$ $\mathrm{R} \$ 2.000,00$ (23,17\%). O gasto médio diário dos visitantes foi destacado por pessoas provenientes do Distrito Federal $(\mathrm{R} \$ 60,72)$.

3. Características do agrupamento

Predominou o deslocamento com família $(41,78 \%)$ com permanência de dois $(25,33 \%)$ há três dias $(25,66 \%)$ e agrupamento de 2 pessoas $(31,91 \%)$.

4. Características da viagem

Os dados revelam que a maior parcela hospedou-se em hotel/pousada/apart-hotel $(57,89 \%)$, viajando de carro $(83,55 \%)$, e as principais atividades desenvolvidas foram relaxar/descansar $(68,42 \%)$, rios/cachoeiras/lagos $(57,89 \%)$, caminhar e apreciar a natureza $(53,29 \%)$, e aprender sobre a região (24,01\%). Já visitou antes o município $(57,89 \%)$ e pretende voltar $(83,22 \%)$. 


\section{Características motivacionais}

A maioria deslocou-se a turismo $(89,47 \%)$. A forma de indução da viagem foi através de parentes e amigos $(69,41 \%)$.

6. Características perceptórias

Em relação à infra-estrutura do município, foram consideradas boas : acesso ao município $(51,64 \%)$, sinalização nas rodovias $(34,54 \%)$, sinalização dentro do município (34,54\%), limpeza urbana (43,09\%), latões de lixo (28,95\%), iluminação pública $(36,51 \%)$, serviço de telefonia $(29,61 \%)$, serviços de transporte de uso público $(3,29 \%)$, segurança $(26,32 \%)$ e serviços médicos/hospitalares $(5,59 \%)$. Foi avaliado como ótima a aparência da cidade $(41,78 \%)$.

Sobre os atrativos, os visitantes consideraram como bons: acesso aos atrativos (27,96\%), sinalização dentro dos atrativos $(21,38 \%)$, patrimônio histórico $(35,20 \%)$, limpeza dos atrativos (30,59\%), matas (22,37\%), monumentos $(16,12 \%)$, cavernas/grutas/serras/morros (10,20\%) e segurança nos atrativos (20,72\%). Foi avaliado como regular a sinalização até os atrativos (20,39\%) e como ótimos rios/cachoeiras/lagos $(31,25 \%)$.

Sobre os equipamentos e serviços turísticos, os visitantes consideraram como bons: hospedagem $(38,16 \%)$, alimentação $(42,11 \%)$, informações $(42,43 \%)$, atendimento $(44,08 \%)$, entretenimentos $(34,54 \%)$ e os preços $(28,62 \%)$. A hospitalidade foi avaliada como ótima $(41,12 \%)$.

Dos visitantes entrevistados, 58,88\% não encontraram guia na região; dos que encontraram $35 \%$ utilizou seus serviços e $42,86 \%$ os consideraram ótimos. 


\section{3 - Formatação dos dados - $\underline{\text { TABELAS }}$}

As tabelas foram construídas obedecendo ao número específico de itens do último questionário utilizado nas Férias de Julho, isso porque, subtende-se que as mudanças necessárias para adequar tal questionário, já foram todas realizadas e conseqüentemente, o último questionário seria o mais adequado.

\section{Perfil e Motivação do Visitante}

Tabela 1 - Local de Residência

\begin{tabular}{l|c|c|c|c|c|c}
\hline \multicolumn{1}{c}{ Variáveis } & $\begin{array}{c}\text { Semana } \\
\text { Santa }\end{array}$ & $\begin{array}{c}\text { Final de } \\
\text { Semana } \\
\text { Comum }\end{array}$ & $\begin{array}{c}\text { Festa do } \\
\text { Divino } \\
\text { Cavalhadas }\end{array}$ & $\begin{array}{c}\text { Férias de } \\
\text { Julho }\end{array}$ & $\begin{array}{c}\text { Média } \\
\text { Parcial }\end{array}$ & $\begin{array}{c}\text { Média } \\
\text { Total }\end{array}$ \\
\hline $\begin{array}{l}\text { Distrito } \\
\text { Federal }\end{array}$ & $49,24 \%$ & $50,89 \%$ & $30,41 \%$ & $39,47 \%$ & $42,50 \%$ & $37,45 \%$ \\
\hline Goiânia & $29,80 \%$ & $23,21 \%$ & $31,76 \%$ & $25,00 \%$ & $27,44 \%$ & $24,18 \%$ \\
\hline $\begin{array}{l}\text { Interior de } \\
\text { Goiás }\end{array}$ & $8,59 \%$ & $9,82 \%$ & $21,62 \%$ & $9,21 \%$ & $12,31 \%$ & $10,85 \%$ \\
\hline São Paulo & - & - & - & $12,17 \%$ & $12,17 \%$ & $10,73 \%$ \\
\hline $\begin{array}{l}\text { Outros } \\
\text { estados }\end{array}$ & $12,37 \%$ & $14,29 \%$ & $14,19 \%$ & $12,17 \%$ & $13,26 \%$ & $11,69 \%$ \\
\hline $\begin{array}{l}\text { Outros } \\
\text { países }\end{array}$ & - & $1,79 \%$ & $2,03 \%$ & $1,97 \%$ & $5,79 \%$ & $5,10 \%$ \\
\hline Total & $100 \%$ & $100 \%$ & $100 \%$ & $100 \%$ & $113,47 \%$ & $100 \%$ \\
\hline
\end{tabular}

$\underline{\text { Média Parcial }}=\Sigma$ das variável dividido / $4($ ou / 3, / 2, / 1 ). Ex: 49,24 +50,89+30,41+39,47 $=170,01 / 4=$ $42,50 \%$.

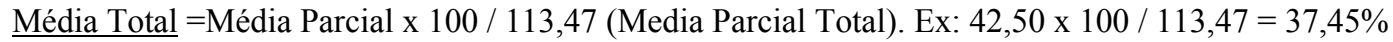

(-) Sem resposta.

Analise da Tabela 1: percebe-se que a maioria dos visitantes que freqüentaram o município de Pirenópolis nas quatro ocasiões pesquisadas era em sua maioria, oriundos do Distrito Federal (37,45\%), seguidos de visitantes da cidade de Goiânia $(24,18 \%)$ e de outros estados $(11,69 \%)$. 
Obs: pode-se perceber que o questionário sofreu alterações ao longo da pesquisa, foram acrescentadas variáveis que não existiam no primeiro momento (Semana Santa) e posteriormente, foram acrescidas nas férias de julho (variável São Paulo). Isso ocorreu devido à necessidade e percepção dos pesquisadores em melhorar o questionário.

Tabela 2 - Sexo

\begin{tabular}{l|c|c|c|c|c|c}
\hline Variáveis & $\begin{array}{c}\text { Semana } \\
\text { Santa }\end{array}$ & $\begin{array}{c}\text { Final de } \\
\text { Semana } \\
\text { Comum }\end{array}$ & $\begin{array}{c}\text { Festa do } \\
\text { Divino } \\
\text { Cavalhadas }\end{array}$ & $\begin{array}{c}\text { Férias de } \\
\text { Julho }\end{array}$ & $\begin{array}{c}\text { Média } \\
\text { Parcial }\end{array}$ & $\begin{array}{c}\text { Média } \\
\text { Total }\end{array}$ \\
\hline Feminino & $47,86 \%$ & $56,70 \%$ & $46,28 \%$ & $53,45 \%$ & $51,07 \%$ & $51,07 \%$ \\
\hline Masculino & $52,14 \%$ & $43,30 \%$ & $53,72 \%$ & $46,55 \%$ & $48,93 \%$ & $48,93 \%$ \\
\hline Total & $100 \%$ & $100 \%$ & $100 \%$ & $100 \%$ & $100 \%$ & $100 \%$ \\
\hline
\end{tabular}

Analise da Tabela 2: a maioria dos visitantes, nos quatro períodos pesquisados, foi do sexo feminino $(51,07 \%)$.

Obs: esta variável não foi alterada em nenhum momento.

Tabela 3 - Idade

\begin{tabular}{l|c|c|c|c|c|c}
\hline \multicolumn{1}{c|}{ Variáveis } & $\begin{array}{c}\text { Semana } \\
\text { Santa }\end{array}$ & $\begin{array}{c}\text { Final de } \\
\text { Semana } \\
\text { Comum }\end{array}$ & $\begin{array}{c}\text { Festa do } \\
\text { Divino } \\
\text { Cavalhadas }\end{array}$ & $\begin{array}{c}\text { Férias de } \\
\text { Julho }\end{array}$ & $\begin{array}{c}\text { Média } \\
\text { Parcial }\end{array}$ & $\begin{array}{c}\text { Média } \\
\text { Total }\end{array}$ \\
\hline $\mathbf{1 5}$ a 19 & $9,82 \%$ & $5,35 \%$ & $7,43 \%$ & $8,55 \%$ & $7,78 \%$ & $7,78 \%$ \\
\hline $\mathbf{2 0}$ a 29 & $44,33 \%$ & $33,93 \%$ & $35,81 \%$ & $31,91 \%$ & $36,49 \%$ & $36,49 \%$ \\
\hline $\mathbf{3 0}$ a 39 & $22,17 \%$ & $26,79 \%$ & $24,32 \%$ & $27,30 \%$ & $25,14 \%$ & $25,14 \%$ \\
\hline $\mathbf{4 0}$ a 49 & $14,36 \%$ & $18,75 \%$ & $15,54 \%$ & $20,72 \%$ & $17,34 \%$ & $17,34 \%$ \\
\hline $\mathbf{5 0}$ a 59 & $4,03 \%$ & $8,93 \%$ & $8,79 \%$ & $9,21 \%$ & $7,74 \%$ & $7,74 \%$ \\
\hline $\mathbf{6 0}$ ou mais & $2,78 \%$ & $4,46 \%$ & $6,76 \%$ & $1,97 \%$ & $3,99 \%$ & $3,99 \%$ \\
\hline $\begin{array}{l}\text { Não } \\
\text { respondeu }\end{array}$ & $2,51 \%$ & $1,79 \%$ & $1,35 \%$ & $0,99 \%$ & $1,66 \%$ & $1,66 \%$ \\
\hline Total & $100 \%$ & $100 \%$ & $100 \%$ & $100 \%$ & $100 \%$ & $100 \%$ \\
\hline
\end{tabular}

Análise da Tabela 3: a faixa etária predominante é a média entre 20 a 29 anos (36,49\%), seguida pela 30 a 39 anos $(25,14 \%)$. 
Tabela 4 - Hábito de viagem

\begin{tabular}{l|c|c|c|c|c|c}
\hline \multicolumn{1}{c|}{ Variáveis } & $\begin{array}{c}\text { Semana } \\
\text { Santa }\end{array}$ & $\begin{array}{c}\text { Final de } \\
\text { Semana } \\
\text { Comum }\end{array}$ & $\begin{array}{c}\text { Festa do } \\
\text { Divino } \\
\text { Cavalhadas }\end{array}$ & $\begin{array}{c}\text { Férias de } \\
\text { Julho }\end{array}$ & $\begin{array}{c}\text { Média } \\
\text { Parcial }\end{array}$ & $\begin{array}{c}\text { Média } \\
\text { Total }\end{array}$ \\
\hline Sozinho & $3,02 \%$ & $10,71 \%$ & $4,73 \%$ & $7,57 \%$ & $6,50 \%$ & $6,15 \%$ \\
\hline Casal & - & $22,32 \%$ & $14,86 \%$ & $26,97 \%$ & $21,38 \%$ & $20,25 \%$ \\
\hline Com família & $55,42 \%$ & $23,21 \%$ & $35,81 \%$ & $41,78 \%$ & $39,05 \%$ & $37,00 \%$ \\
\hline Com amigos & $37,53 \%$ & $33,04 \%$ & $30,41 \%$ & $20,72 \%$ & $30,43 \%$ & $28,82 \%$ \\
\hline $\begin{array}{l}\text { C/ família } \mathbf{e} \\
\text { amigos }\end{array}$ & $0,76 \%$ & - & $0,68 \%$ & $1,64 \%$ & $1,03 \%$ & $0,97 \%$ \\
\hline Excursão & $0,76 \%$ & $8,94 \%$ & $8,11 \%$ & $0,66 \%$ & $4,61 \%$ & $4,36 \%$ \\
\hline $\begin{array}{l}\text { Não } \\
\text { respondeu }\end{array}$ & $2,51 \%$ & $1,79 \%$ & $5,40 \%$ & $0,66 \%$ & $2,59 \%$ & $2,45 \%$ \\
\hline Total & $100 \%$ & $100 \%$ & $100 \%$ & & $105,59 \%$ & $100 \%$ \\
\hline
\end{tabular}

Análise da Tabela 4: nota-se que os entrevistados viajam em sua maioria com a família (37\%), em segundo com amigos (28,82\%). Nesta variável o item casal não aparece nos questionários da Semana Santa e o item com família e amigos não está no questionário do Final de Semana Comum.

Tabela 5 - Agrupamento

\begin{tabular}{|c|c|c|c|c|c|c|}
\hline Variáveis & $\begin{array}{l}\text { Semana } \\
\text { Santa }\end{array}$ & $\begin{array}{l}\text { Final de } \\
\text { Semana } \\
\text { Comum } \\
\end{array}$ & $\begin{array}{c}\text { Festa do } \\
\text { Divino } \\
\text { Cavalhadas } \\
\end{array}$ & $\begin{array}{l}\text { Férias de } \\
\text { Julho }\end{array}$ & $\begin{array}{l}\text { Média } \\
\text { Parcial }\end{array}$ & $\begin{array}{c}\text { Média } \\
\text { Total }\end{array}$ \\
\hline Sozinho & - & - & - & $9,54 \%$ & 9,54 & $8,61 \%$ \\
\hline 1 pessoa & - & - & $5,41 \%$ & $6,91 \%$ & 6,16 & $5,55 \%$ \\
\hline 2 pessoas & - & - & $16,89 \%$ & $31,91 \%$ & 24,40 & $22,01 \%$ \\
\hline 3 pessoas & - & - & $3,38 \%$ & $10,53 \%$ & 6,95 & $6,27 \%$ \\
\hline 4 pessoas & - & - & $1,35 \%$ & $15,13 \%$ & 8,24 & $7,43 \%$ \\
\hline 5 pessoas & - & - & $3,38 \%$ & $6,91 \%$ & 5,14 & $4,63 \%$ \\
\hline $\begin{array}{llll}\begin{array}{l}\text { Entre } \\
\text { pessoas }\end{array} & \text { e } & 10 \\
\end{array}$ & - & - & $0,68 \%$ & $11,51 \%$ & 12,19 & $11,00 \%$ \\
\hline $\begin{array}{lll}\begin{array}{l}\text { Mais de } \\
\text { pessoas }\end{array} & 10 \\
\end{array}$ & - & - & $0,68 \%$ & $6,91 \%$ & 3,80 & $3,43 \%$ \\
\hline Não respondeu & - & - & $68,24 \%$ & $0,66 \%$ & 34,45 & $31,07 \%$ \\
\hline Total & - & - & $100 \%$ & $100 \%$ & $110,87 \%$ & $100 \%$ \\
\hline
\end{tabular}

Análise da Tabela 5: esta pergunta só foi apresentada nos dois últimos momentos da pesquisa (Cavalhadas e Férias de Julho), sendo que, no primeiro o item - sozinho - não apareceu. Podemos concluir que a maioria $(31,07 \%)$ dos entrevistados não respondeu esta pergunta. 
Tabela 6 - Meio de transporte

\begin{tabular}{l|c|c|c|c|c|c}
\hline Variáveis & $\begin{array}{c}\text { Semana } \\
\text { Santa }\end{array}$ & $\begin{array}{c}\text { Final de } \\
\text { Semana } \\
\text { Comum }\end{array}$ & $\begin{array}{c}\text { Festa do } \\
\text { Divino } \\
\text { Cavalhadas }\end{array}$ & $\begin{array}{c}\text { Férias de } \\
\text { Julho }\end{array}$ & $\begin{array}{c}\text { Média } \\
\text { Parcial }\end{array}$ & $\begin{array}{c}\text { Média } \\
\text { Total }\end{array}$ \\
\hline Avião & $0,77 \%$ & 1,63 & 0,68 & $2,83 \%$ & 1,48 & $1,47 \%$ \\
\hline Carro & $89,00 \%$ & 77,44 & 78,38 & $83,42 \%$ & 82,06 & $81,36 \%$ \\
\hline Moto & $2,74 \%$ & 0,63 & 3,38 & $1,84 \%$ & 2,15 & $2,13 \%$ \\
\hline Ônibus & $6,74 \%$ & 17,70 & 16,22 & $10,07 \%$ & 12,68 & $12,57 \%$ \\
\hline Outros & $0,25 \%$ & 2,60 & - & $1,84 \%$ & 1,56 & $1,55 \%$ \\
\hline $\begin{array}{l}\text { Não } \\
\text { respondeu }\end{array}$ & $0,50 \%$ & - & 1,35 & - & 0,93 & $0,92 \%$ \\
\hline Total & $100 \%$ & $100 \%$ & $100 \%$ & $100 \%$ & $100,86 \%$ & $100 \%$ \\
\hline
\end{tabular}

Análise da Tabela 6: o meio de transporte mais utilizado para chegar em Pirenópolis é consideravelmente, o carro $(81,36 \%)$.

Tabela 7 - Gasto médio/dia

\begin{tabular}{l|c|c|c|c|c|c}
\hline \multicolumn{1}{c|}{ Variáveis } & $\begin{array}{c}\text { Semana } \\
\text { Santa }\end{array}$ & $\begin{array}{c}\text { Final de } \\
\text { Semana } \\
\text { Comum }\end{array}$ & $\begin{array}{c}\text { Festa do } \\
\text { Divino } \\
\text { Cavalhadas }\end{array}$ & $\begin{array}{c}\text { Férias de } \\
\text { Julho }\end{array}$ & $\begin{array}{c}\text { Média } \\
\text { Parcial } \\
\text { R\$ }\end{array}$ & $\begin{array}{c}\text { Média } \\
\text { Total } \\
\%\end{array}$ \\
\hline $\begin{array}{l}\text { Distrito } \\
\text { Federal }\end{array}$ & $\mathrm{R} \$ 50,09$ & $\mathrm{R} \$ 51,39$ & $\mathrm{R} \$ 110,69$ & $\mathrm{R} \$ 60,72$ & $\mathrm{R} \$ 68,22$ & $18,97 \%$ \\
\hline Goiânia & $\mathrm{R} \$ 42,39$ & $\mathrm{R} \$ 40,51$ & $\mathrm{R} \$ 96,98$ & $\mathrm{R} \$ 45,96$ & $\mathrm{R} \$ 56,46$ & $15,67 \%$ \\
\hline $\begin{array}{l}\text { Interior de } \\
\text { Goiás }\end{array}$ & $\mathrm{R} \$ 56,56$ & $\mathrm{R} \$ 34,27$ & $\mathrm{R} \$ 72,05$ & $\mathrm{R} \$ 40,25$ & $\mathrm{R} \$ 50,78$ & $14,12 \%$ \\
\hline São Paulo & - & - & - & $\mathrm{R} \$ 45,54$ & $\mathrm{R} \$ 45,54$ & $12,76 \%$ \\
\hline $\begin{array}{l}\text { Outros } \\
\text { estados }\end{array}$ & $\mathrm{R} \$ 66,94$ & $\mathrm{R} \$ 32,40$ & $\mathrm{R} \$ 77,57$ & $\mathrm{R} \$ 59,54$ & $\mathrm{R} \$ 59,11$ & $16,44 \%$ \\
\hline $\begin{array}{l}\text { Outros } \\
\text { países }\end{array}$ & - & $\mathrm{R} \$ 150,00$ & $\mathrm{R} \$ 50,00$ & $\mathrm{R} \$ 38,33$ & $\mathrm{R} \$ 79,44$ & $22,09 \%$ \\
\hline Total & $\mathrm{R} \$ 215,98$ & $\mathrm{R} \$ 308,57$ & $\mathrm{R} \$ 407,29$ & $\mathrm{R} \$ 290,34$ & $\mathrm{R} \$ 359,55$ & $100 \%$ \\
\hline
\end{tabular}

Análise da Tabela 7: o gasto médio dos visitantes estrangeiro é em média R\$79,44 (22,09\%), em segundo lugar fica dos Brasilienses com $\mathrm{R} \$ 68,22$ de gasto médio $(18,97 \%)$ e os goianienses gastam em média $\mathrm{R} \$ 56,46(15,67 \%)$. 
Tabela 8 - Local de hospedagem

\begin{tabular}{l|c|c|c|c|c|c}
\hline \multicolumn{1}{c|}{ Variáveis } & $\begin{array}{c}\text { Semana } \\
\text { Santa }\end{array}$ & $\begin{array}{c}\text { Final de } \\
\text { Semana } \\
\text { Comum }\end{array}$ & $\begin{array}{c}\text { Festa do } \\
\text { Divino } \\
\text { Cavalhadas }\end{array}$ & $\begin{array}{c}\text { Férias de } \\
\text { Julho }\end{array}$ & $\begin{array}{c}\text { Média } \\
\text { Parcial }\end{array}$ & $\begin{array}{c}\text { Média } \\
\text { Total } \\
\%\end{array}$ \\
\hline Camping & $12,34 \%$ & - & $5,41 \%$ & $7,57 \%$ & $8,44 \%$ & $8,27 \%$ \\
\hline Casa alugada & $9,82 \%$ & $1,79 \%$ & $4,05 \%$ & $4,61 \%$ & $5,07 \%$ & $5,00 \%$ \\
\hline $\begin{array}{l}\text { Casa de amigos } \\
\text { parentes }\end{array}$ & $4,28 \%$ & $16,07 \%$ & $20,95 \%$ & $12,50 \%$ & $13,45 \%$ & $13,17 \%$ \\
\hline Casa própria & $11,09 \%$ & $5,36 \%$ & $7,43 \%$ & $2,63 \%$ & $6,63 \%$ & $6,49 \%$ \\
\hline Hotel/pousada/apart & $48,61 \%$ & $59,82 \%$ & $37,16 \%$ & $57,89 \%$ & $50,87 \%$ & $49,81 \%$ \\
\hline Outros & $13,61 \%$ & $6,25 \%$ & $10,14 \%$ & $9,54 \%$ & $9,88 \%$ & $9,66 \%$ \\
\hline Não respondeu & $0,25 \%$ & $10,71 \%$ & $14,86 \%$ & $5,26 \%$ & $7,77 \%$ & $7,60 \%$ \\
\hline Total & $100 \%$ & $100 \%$ & $100 \%$ & $100 \%$ & $102,11 \%$ & $100 \%$ \\
\hline
\end{tabular}

Análise da Tabela 8: os visitantes em sua maioria utilizam como local de hospedagem os hotéis e pousadas $(49,81 \%)$, seguidos por hospedagem em casa de amigos e parentes $(13,17 \%)$. Em Pirenópolis a maioria dos meios de hospedagem são pousadas.

Tabela 9 - Motivo da Viagem

\begin{tabular}{l|c|c|c|c|c|c}
\hline \multicolumn{1}{c|}{ Variáveis } & $\begin{array}{c}\text { Semana } \\
\text { Santa }\end{array}$ & $\begin{array}{c}\text { Final de } \\
\text { Semana } \\
\text { Comum }\end{array}$ & $\begin{array}{c}\text { Festa do } \\
\text { Divino } \\
\text { Cavalhadas }\end{array}$ & $\begin{array}{c}\text { Férias de } \\
\text { Julho }\end{array}$ & $\begin{array}{c}\text { Média } \\
\text { Parcial }\end{array}$ & $\begin{array}{c}\text { Média } \\
\text { Total } \\
\%\end{array}$ \\
\hline Congresso & - & $0,70 \%$ & - & $1,11 \%$ & $0,91 \%$ & $0,90 \%$ \\
\hline Estudo & - & $7,93 \%$ & $0,75 \%$ & $1,43 \%$ & $3,37 \%$ & $3,32 \%$ \\
\hline Negócios & $1,82 \%$ & $5,16 \%$ & $3,45 \%$ & $2,10 \%$ & $3,13 \%$ & $3,09 \%$ \\
\hline Turismo & $94,51 \%$ & $80,16 \%$ & $87,91 \%$ & $89,11 \%$ & $87,92 \%$ & $86,68 \%$ \\
\hline $\begin{array}{l}\text { Visitar } \\
\text { familiares/amigos }\end{array}$ & $1,56 \%$ & $5,16 \%$ & $5,48 \%$ & $4,17 \%$ & $4,09 \%$ & $4,03 \%$ \\
\hline Outros & $0,81 \%$ & - & $0,31 \%$ & $0,55 \%$ & $0,55 \%$ & $0,54 \%$ \\
\hline Não respondeu & $1,30 \%$ & $0,89 \%$ & $2,10 \%$ & $1,53 \%$ & $1,46 \%$ & $1,44 \%$ \\
\hline Total & $100 \%$ & 100 & $100 \%$ & $100 \%$ & $101,43 \%$ & $100 \%$ \\
\hline
\end{tabular}

Obs. Esta questão permitia ao entrevistado marcar mais de uma resposta

Análise da Tabela 9: percebe-se que o motivo da viagem para a maioria dos entrevistados é o Turismo (86,68\%), seguidos de visitas a familiares e amigos $(4,03 \%)$. 
Tabela 10 - Tempo de permanência

\begin{tabular}{l|c|c|c|c|c|c}
\hline \multicolumn{1}{c}{ Variáveis } & $\begin{array}{c}\text { Semana } \\
\text { Santa }\end{array}$ & $\begin{array}{c}\text { Final de } \\
\text { Semana } \\
\text { Comum }\end{array}$ & $\begin{array}{c}\text { Festa do } \\
\text { Divino } \\
\text { Cavalhadas }\end{array}$ & $\begin{array}{c}\text { Férias de } \\
\text { Julho }\end{array}$ & $\begin{array}{c}\text { Média } \\
\text { Parcial }\end{array}$ & $\begin{array}{c}\text { Média } \\
\text { Total } \\
\text { \% }\end{array}$ \\
\hline $\mathbf{1}$ dia & $10,58 \%$ & $16,07 \%$ & $24,32 \%$ & $15,79 \%$ & $16,68 \%$ & $16,68 \%$ \\
\hline $\mathbf{2 ~ d i a s ~}$ & $16,12 \%$ & $50,00 \%$ & $44,59 \%$ & $25,33 \%$ & $34,01 \%$ & $34,01 \%$ \\
\hline $\mathbf{3}$ dias & $16,37 \%$ & $20,54 \%$ & $16,22 \%$ & $25,66 \%$ & $19,68 \%$ & $19,68 \%$ \\
\hline $\mathbf{4}$ dias & $34,01 \%$ & $3,57 \%$ & $5,41 \%$ & $7,57 \%$ & $12,64 \%$ & $12,64 \%$ \\
\hline $\mathbf{5}$ dias & $18,64 \%$ & $1,79 \%$ & $1,35 \%$ & $6,58 \%$ & $7,08 \%$ & $7,08 \%$ \\
\hline $\mathbf{6}$ dias & $1,51 \%$ & $0,02 \%$ & $0,68 \%$ & $1,32 \%$ & $0,93 \%$ & $0,93 \%$ \\
\hline $\mathbf{7}$ dias & $0,50 \%$ & $0,89 \%$ & $2,03 \%$ & $4,28 \%$ & $1,92 \%$ & $1,92 \%$ \\
\hline Mais de 7 dias & $0,76 \%$ & $1,79 \%$ & $2,70 \%$ & $11,51 \%$ & $4,18 \%$ & $4,18 \%$ \\
\hline Não respondeu & $1,51 \%$ & $5,37 \%$ & $2,70 \%$ & $1,97 \%$ & $2,88 \%$ & $2,88 \%$ \\
\hline Total & $100 \%$ & $100 \%$ & $100 \%$ & $100 \%$ & 100 & $100 \%$ \\
\hline
\end{tabular}

Análise da tabela 10: o tempo de permanência dos visitantes nas ocasiões pesquisadas é em sua maioria de dois dias $(34,01 \%)$, seguidos de três dias $(19,68 \%)$. Pode-se analisar que o tempo de permanecia é maior nos finais de semana.

Tabela 11 - Meios de comunicação

\begin{tabular}{l|c|c|c|c|c|c}
\hline \multicolumn{1}{c|}{ Variáveis } & $\begin{array}{c}\text { Semana } \\
\text { Santa }\end{array}$ & $\begin{array}{c}\text { Final de } \\
\text { Semana } \\
\text { Comum }\end{array}$ & $\begin{array}{c}\text { Festa do } \\
\text { Divino } \\
\text { Cavalhadas }\end{array}$ & $\begin{array}{c}\text { Férias de } \\
\text { Julho }\end{array}$ & $\begin{array}{c}\text { Média } \\
\text { Parcial }\end{array}$ & $\begin{array}{c}\text { Média } \\
\text { Total } \\
\%\end{array}$ \\
\hline Folders/guias & $4,04 \%$ & $7,14 \%$ & $5,41 \%$ & $4,28 \%$ & $5,22 \%$ & $4,07 \%$ \\
\hline Internet & $4,03 \%$ & $7,14 \%$ & $1,35 \%$ & $4,93 \%$ & $4,36 \%$ & $3,40 \%$ \\
\hline Jornal & $3,02 \%$ & $5,36 \%$ & $8,11 \%$ & $6,91 \%$ & $5,85 \%$ & $4,56 \%$ \\
\hline $\begin{array}{l}\text { Parentes } \\
\text { amigos }\end{array}$ & $76,83 \%$ & $77,68 \%$ & $66,22 \%$ & $69,41 \%$ & $72,54 \%$ & $56,51 \%$ \\
\hline Rádio & $0,76 \%$ & $0,89 \%$ & - & $0,33 \%$ & $0,66 \%$ & $0,51 \%$ \\
\hline Revista & $2,27 \%$ & $3,57 \%$ & $5,41 \%$ & $2,63 \%$ & $13,88 \%$ & $10,81 \%$ \\
\hline Televisão & $7,56 \%$ & $15,18 \%$ & $14,86 \%$ & $12,83 \%$ & $12,61 \%$ & $9,82 \%$ \\
\hline Outros & $20,91 \%$ & $12,50 \%$ & $8,11 \%$ & $2,30 \%$ & $10,96 \%$ & $8,54 \%$ \\
\hline Não respondeu & $1,26 \%$ & $0,89 \%$ & $4,05 \%$ & $2,96 \%$ & $2,29 \%$ & $1,78 \%$ \\
\hline Total & $120,68 \%$ & $130,35 \%$ & $113,52 \%$ & $106,58 \%$ & $128,37 \%$ & $100 \%$ \\
\hline
\end{tabular}

Obs. Esta questão permitia ao entrevistado marcar mais de uma resposta

Análise da Tabela 11:os meios de comunicação para divulgação da região são em sua maioria indicações de parentes e amigos $(56,51 \%)$ e também, através de revistas $(10,81 \%)$ e televisão $(9,82 \%)$. 
Tabela 12 - Escolaridade

\begin{tabular}{l|c|c|c|c|c|c}
\hline \multicolumn{1}{c|}{ Variáveis } & $\begin{array}{c}\text { Semana } \\
\text { Santa }\end{array}$ & $\begin{array}{c}\text { Final de } \\
\text { Semana } \\
\text { Comum }\end{array}$ & $\begin{array}{c}\text { Festa do } \\
\text { Divino } \\
\text { Cavalhadas }\end{array}$ & $\begin{array}{c}\text { Férias de } \\
\text { Julho }\end{array}$ & $\begin{array}{c}\text { Média } \\
\text { Parcial }\end{array}$ & $\begin{array}{c}\text { Média } \\
\text { Total } \\
\%\end{array}$ \\
\hline Fundamental & $3,53 \%$ & 1,79 & 1,35 & 0,99 & $1,92 \%$ & $1,85 \%$ \\
\hline Médio & $29,97 \%$ & 21,42 & 23,65 & 21,71 & $24,19 \%$ & $23,29 \%$ \\
\hline Superior & $64,48 \%$ & 68,75 & 62,84 & 53,29 & $62,34 \%$ & $60,02 \%$ \\
\hline Pós-graduação & - & 8,04 & 7,43 & 18,75 & $11,41 \%$ & $10,99 \%$ \\
\hline Não respondeu & $2,02 \%$ & - & 4,73 & 5,26 & $4,00 \%$ & $3,85 \%$ \\
\hline Total & $100 \%$ & $100 \%$ & $100 \%$ & $100 \%$ & 103,86 & $100 \%$ \\
\hline
\end{tabular}

Análise da Tabela 12: os visitantes que freqüentam Pirenópolis possuem escolaridade superior $(60,02 \%)$, conseqüentemente possuem nível cultural maior e são mais exigentes.

Tabela 13 - Local de Trabalho

\begin{tabular}{l|c|c|c|c|c|c}
\hline \multicolumn{1}{c|}{ Variáveis } & $\begin{array}{c}\text { Semana } \\
\text { Santa }\end{array}$ & $\begin{array}{c}\text { Final de } \\
\text { Semana } \\
\text { Comum }\end{array}$ & $\begin{array}{c}\text { Festa do } \\
\text { Divino } \\
\text { Cavalhadas }\end{array}$ & $\begin{array}{c}\text { Férias de } \\
\text { Julho }\end{array}$ & $\begin{array}{c}\text { Média } \\
\text { Parcial }\end{array}$ & $\begin{array}{c}\text { Média } \\
\text { Total } \\
\%\end{array}$ \\
\hline Aposentado & $2,52 \%$ & $3,87 \%$ & $1,35 \%$ & $2,85 \%$ & $2,55 \%$ & $2,55 \%$ \\
\hline Do lar & $1,26 \%$ & $2,09 \%$ & - & $1,53 \%$ & $1,53 \%$ & $1,53 \%$ \\
\hline Emprego privado & $24,43 \%$ & $29,73 \%$ & $22,97 \%$ & $32,12 \%$ & $27,07 \%$ & $27,07 \%$ \\
\hline Emprego público & $22,67 \%$ & $21,73 \%$ & $31,77 \%$ & $28,18 \%$ & $26,00 \%$ & $26,00 \%$ \\
\hline Empresário & $6,30 \%$ & $7,45 \%$ & $2,70 \%$ & $5,17 \%$ & $5,31 \%$ & $5,31 \%$ \\
\hline Estudante & $19,65 \%$ & $11,91 \%$ & $16,89 \%$ & $9,10 \%$ & $14,29 \%$ & $14,29 \%$ \\
\hline $\begin{array}{l}\text { Profissional } \\
\text { liberal }\end{array}$ & $15,86 \%$ & $22,62 \%$ & $15,54 \%$ & $15,35 \%$ & $17,24 \%$ & $17,24 \%$ \\
\hline Outros & $2,52 \%$ & $0,30 \%$ & - & $3,51 \%$ & $2,01 \%$ & $2,01 \%$ \\
\hline Não respondeu & $4,79 \%$ & $0,30 \%$ & $8,78 \%$ & $2,19 \%$ & $4,00 \%$ & $4,00 \%$ \\
\hline Total & $100 \%$ & $100 \%$ & $100 \%$ & $100 \%$ & $100 \%$ & $100 \%$ \\
\hline
\end{tabular}

Análise da Tabela 13: a maioria dos entrevistados possui empregos privados $(27,07 \%)$ ou empregos públicos (26\%). 
Tabela 14 - Renda Pessoal

\begin{tabular}{|c|c|c|c|c|c|c|}
\hline Variáveis & $\begin{array}{c}\text { Semana } \\
\text { Santa }\end{array}$ & $\begin{array}{l}\text { Final de } \\
\text { Semana } \\
\text { Comum }\end{array}$ & $\begin{array}{c}\text { Festa do } \\
\text { Divino } \\
\text { Cavalhadas } \\
\end{array}$ & $\begin{array}{c}\text { Férias de } \\
\text { Julho }\end{array}$ & $\begin{array}{l}\text { Média } \\
\text { Parcial }\end{array}$ & $\begin{array}{c}\text { Média } \\
\text { Total } \\
\% \\
\end{array}$ \\
\hline Até R\$200,00 & $1,26 \%$ & $3,57 \%$ & $2,70 \%$ & $2,85 \%$ & $2,59 \%$ & $2,59 \%$ \\
\hline $\begin{array}{l}\text { Entre R\$201,00 e } \\
R \$ 400,00\end{array}$ & $4,28 \%$ & $4,46 \%$ & $6,76 \%$ & $1,53 \%$ & $4,26 \%$ & $4,26 \%$ \\
\hline $\begin{array}{l}\text { Entre R\$401,00 e } \\
\text { R } \$ 600,00\end{array}$ & $8,31 \%$ & $4,46 \%$ & $8,11 \%$ & $32,12 \%$ & $13,25 \%$ & $13,25 \%$ \\
\hline $\begin{array}{l}\text { Entre } \quad \mathrm{R} \$ 601,00 \\
\mathrm{R} \$ 1000,00\end{array}$ & $10,83 \%$ & $10,71 \%$ & $10,81 \%$ & $28,18 \%$ & $15,13 \%$ & $15,13 \%$ \\
\hline $\begin{array}{l}\text { Entre R\$1001,00 e } \\
\mathrm{R} \$ 2000,00\end{array}$ & $23,17 \%$ & $15,18 \%$ & $21,62 \%$ & $5,17 \%$ & $16,29 \%$ & $16,29 \%$ \\
\hline $\begin{array}{l}\text { Entre } \mathrm{R} \$ 2001,00 \text { e } \\
\mathrm{R} \$ 4000,00\end{array}$ & $21,91 \%$ & $23,21 \%$ & $14,86 \%$ & $9,10 \%$ & $17,27 \%$ & $17,27 \%$ \\
\hline Mais de $\mathrm{R} \$ \mathbf{4 0 0 0 , 0 0}$ & $15,37 \%$ & $25,00 \%$ & $18,24 \%$ & $15,35 \%$ & $18,49 \%$ & $18,49 \%$ \\
\hline $\begin{array}{l}\text { Não possui renda } \\
\text { própria }\end{array}$ & $11,84 \%$ & $7,14 \%$ & $8,78 \%$ & $3,51 \%$ & $7,82 \%$ & $7,82 \%$ \\
\hline Não respondeu & $3,02 \%$ & $6,27 \%$ & $8,11 \%$ & $2,19 \%$ & $4,90 \%$ & $4,90 \%$ \\
\hline Total & $100 \%$ & $100 \%$ & $100 \%$ & $100 \%$ & $100 \%$ & $100 \%$ \\
\hline
\end{tabular}

Análise da Tabela 14: A renda pessoal da maioria dos entrevistados é mais de $\mathrm{R} \$ 4000,00$ $(18,49 \%)$, seguido da estimativa entre $\mathrm{R} \$ 2001,00$ e $\mathrm{R} \$ 4000,00$, então, podemos classificar os visitantes entrevistados como classe média alta.

Tabela 15 - Atividades durante a visita

\begin{tabular}{l|c|c|c|c|c|c}
\hline \multicolumn{1}{c|}{ Variáveis } & $\begin{array}{c}\text { Semana } \\
\text { Santa }\end{array}$ & $\begin{array}{c}\text { Final de } \\
\text { Semana } \\
\text { Comum }\end{array}$ & $\begin{array}{c}\text { Festa do } \\
\text { Divino } \\
\text { Cavalhadas }\end{array}$ & $\begin{array}{c}\text { Férias de } \\
\text { Julho }\end{array}$ & $\begin{array}{c}\text { Média } \\
\text { Parcial }\end{array}$ & $\begin{array}{c}\text { Média } \\
\text { Total } \\
\%\end{array}$ \\
\hline Apreciar a natureza & $45,84 \%$ & $29,46 \%$ & $25,00 \%$ & $53,29 \%$ & $38,40 \%$ & $14,75 \%$ \\
\hline $\begin{array}{l}\text { Aprender sobre a } \\
\text { região }\end{array}$ & $19,14 \%$ & $15,18 \%$ & $22,30 \%$ & $24,01 \%$ & $20,16 \%$ & $7,74 \%$ \\
\hline Atividades náuticas & $1,76 \%$ & $0,89 \%$ & $1,35 \%$ & $1,97 \%$ & $1,49 \%$ & $0,57 \%$ \\
\hline Caminhar & $55,42 \%$ & $43,75 \%$ & $42,57 \%$ & $53,29 \%$ & $48,76 \%$ & $18,73 \%$ \\
\hline Esoterismo/misticismo & $3,78 \%$ & $0,89 \%$ & $2,70 \%$ & $3,29 \%$ & $2,67 \%$ & $1,03 \%$ \\
\hline Estudo/ensino/pesquisa & $0,76 \%$ & $10,71 \%$ & $2,03 \%$ & $0,99 \%$ & $3,62 \%$ & $1,39 \%$ \\
\hline Gastronomia & - & $17,86 \%$ & $8,11 \%$ & $16,78 \%$ & $14,25 \%$ & $5,47 \%$ \\
\hline Relaxar/descansar & $63,48 \%$ & $45,5 \% 4$ & $50,68 \%$ & $68,42 \%$ & $57,02 \%$ & $21,90 \%$ \\
\hline Religião & - & - & $6,76 \%$ & $1,32 \%$ & $4,04 \%$ & $1,55 \%$ \\
\hline Rios/cachoeiras/lagos & $* 71,28 \%$ & $43,75 \%$ & $55,41 \%$ & $57,89 \%$ & $57,08 \%$ & $21,92 \%$ \\
\hline Visitar cavernas & $5,29 \%$ & $3,57 \%$ & $1,35 \%$ & $1,64 \%$ & $2,96 \%$ & $1,14 \%$ \\
\hline Outras atividades & $7,30 \%$ & $8,04 \%$ & $8,78 \%$ & $2,30 \%$ & $6,61 \%$ & $2,54 \%$ \\
\hline Não respondeu & - & $0,89 \%$ & $7,43 \%$ & $1,64 \%$ & $3,32 \%$ & $1,27 \%$ \\
\hline Total & $274,05 \%$ & $220,49 \%$ & $234,47 \%$ & $286,83 \%$ & $260,38 \%$ & $100 \%$ \\
\hline Ob: Esta $\%$
\end{tabular}

Obs: Esta questão permitia ao entrevistado marcar mais de uma resposta.

*No questionário Semana Santa esta pergunta é: "Tomar banho em ambiente natural". 
Análise da Tabela 15: As atividades mais realizadas durante a visitação no município foram os rios/cachoeiras/lagos $(21,92 \%)$, seguidos pela opção relaxar/descansar $(21,90 \%)$ e fazer caminhadas $(18,73 \%)$. Esta interpretação confirma o potencial da região para o turismo em meio à natureza.

Tabela 16 - Já visitou a região?

\begin{tabular}{l|c|c|c|c|c|c}
\hline \multicolumn{1}{c}{ Variáveis } & $\begin{array}{c}\text { Semana } \\
\text { Santa }\end{array}$ & $\begin{array}{c}\text { Final de } \\
\text { Semana } \\
\text { Comum }\end{array}$ & $\begin{array}{c}\text { Festa do } \\
\text { Divino } \\
\text { Cavalhadas }\end{array}$ & $\begin{array}{c}\text { Férias de } \\
\text { Julho }\end{array}$ & $\begin{array}{c}\text { Média } \\
\text { Parcial }\end{array}$ & $\begin{array}{c}\text { Média } \\
\text { Total }\end{array}$ \\
\hline Já visitou antes & - & $60,71 \%$ & $75,00 \%$ & $57,89 \%$ & $64,53 \%$ & $63,82 \%$ \\
\hline Primeira visita & - & $39,29 \%$ & $20,95 \%$ & $39,47 \%$ & $33,24 \%$ & $32,88 \%$ \\
\hline Não respondeu & - & - & $4,05 \%$ & $2,63 \%$ & $3,34 \%$ & $3,30 \%$ \\
\hline Total & - & $100 \%$ & $100 \%$ & $100 \%$ & $101,11 \%$ & $100 \%$ \\
\hline
\end{tabular}

Análise da Tabela 16: a maioria dos visitantes entrevistados $(63,82 \%)$ já havia visitado a região. Podemos perceber também, que esta pergunta não foi feita nos questionário da Semana Santa.

Tabela 17 - Pretende voltar ao município?

\begin{tabular}{l|c|c|c|c|c|c}
\hline \multicolumn{1}{c|}{ Variáveis } & $\begin{array}{c}\text { Semana } \\
\text { Santa }\end{array}$ & $\begin{array}{c}\text { Final de } \\
\text { Semana } \\
\text { Comum }\end{array}$ & $\begin{array}{c}\text { Festa do } \\
\text { Divino } \\
\text { Cavalhadas }\end{array}$ & $\begin{array}{c}\text { Férias de } \\
\text { Julho }\end{array}$ & $\begin{array}{c}\text { Média } \\
\text { Parcial }\end{array}$ & $\begin{array}{c}\text { Média } \\
\text { Total }\end{array}$ \\
\hline Sim & - & $97,32 \%$ & $85,81 \%$ & $83,22 \%$ & $88,78 \%$ & $73,80 \%$ \\
\hline Não & - & $0,89 \%$ & $3,38 \%$ & - & $2,14 \%$ & $1,78 \%$ \\
\hline Não respondeu & - & $1,79 \%$ & $10,81 \%$ & $16,78 \%$ & $29,38 \%$ & $24,42 \%$ \\
\hline Total & - & $100 \%$ & $100 \%$ & $100 \%$ & $120,30 \%$ & $100 \%$ \\
\hline
\end{tabular}

Análise da Tabela 17: quando perguntados os visitantes responderam que pretendem voltar ao município $(73,80 \%)$. Esta pergunta não foi feita na Semana Santa.

Tabela 18 - Acesso aos guias

\begin{tabular}{l|c|c|c|c|c|c}
\hline \multicolumn{1}{c}{ Variáveis } & $\begin{array}{c}\text { Semana } \\
\text { Santa }\end{array}$ & $\begin{array}{c}\text { Final de } \\
\text { Semana } \\
\text { Comum }\end{array}$ & $\begin{array}{c}\text { Festa do } \\
\text { Divino } \\
\text { Cavalhadas }\end{array}$ & $\begin{array}{c}\text { Férias de } \\
\text { Julho }\end{array}$ & $\begin{array}{c}\text { Média } \\
\text { Parcial }\end{array}$ & $\begin{array}{c}\text { Média } \\
\text { Total }\end{array}$ \\
\hline Sim & $22,17 \%$ & 34,82 & 28,38 & $34,21 \%$ & $29,90 \%$ & $29,90 \%$ \\
\hline Não & $76,32 \%$ & 59,82 & 53,38 & $58,88 \%$ & $62,09 \%$ & $62,09 \%$ \\
\hline Não respondeu & $1,51 \%$ & 5,36 & 18,24 & $6,91 \%$ & $8,01 \%$ & $8,01 \%$ \\
\hline Total & $100 \%$ & $100 \%$ & $100 \%$ & $100 \%$ & $100 \%$ & $100 \%$ \\
\hline
\end{tabular}

Análise da Tabela 18: os visitantes em sua maioria (62,09\%) não tiveram acesso aos guias. 
Tabela 19 - Utilizou serviços dos guias?

\begin{tabular}{l|c|c|c|c|c|c}
\hline \multicolumn{1}{c|}{ Variáveis } & $\begin{array}{c}\text { Semana } \\
\text { Santa }\end{array}$ & $\begin{array}{c}\text { Final de } \\
\text { Semana } \\
\text { Comum }\end{array}$ & $\begin{array}{c}\text { Festa do } \\
\text { Divino } \\
\text { Cavalhadas }\end{array}$ & $\begin{array}{c}\text { Férias de } \\
\text { Julho }\end{array}$ & $\begin{array}{c}\text { Média } \\
\text { Parcial }\end{array}$ & $\begin{array}{c}\text { Média } \\
\text { Total }\end{array}$ \\
\hline Sim & $46,59 \%$ & $48,72 \%$ & $47,62 \%$ & $35,00 \%$ & $44,48 \%$ & $44,48 \%$ \\
\hline Não & $27,27 \%$ & $41,03 \%$ & $35,71 \%$ & $52,00 \%$ & $39,00 \%$ & $39,00 \%$ \\
\hline Não respondeu & $26,14 \%$ & $10,25 \%$ & $16,67 \%$ & $13,00 \%$ & $16,52 \%$ & $16,52 \%$ \\
\hline Total & $100 \%$ & $100 \%$ & $100 \%$ & $100 \%$ & $100 \%$ & $100 \%$ \\
\hline
\end{tabular}

Análise da Tabela 19: dos visitantes que tiveram acesso aos guias $(62,09 \%)$, a maioria de $(44,48 \%)$ utilizou os seus serviços.

Tabela 20 - Avaliação dos serviços dos guias

\begin{tabular}{l|c|c|c|c|c|c}
\hline \multicolumn{1}{c|}{ Variáveis } & $\begin{array}{c}\text { Semana } \\
\text { Santa }\end{array}$ & $\begin{array}{c}\text { Final de } \\
\text { Semana } \\
\text { Comum }\end{array}$ & $\begin{array}{c}\text { Festa do } \\
\text { Divino } \\
\text { Cavalhadas }\end{array}$ & $\begin{array}{c}\text { Férias de } \\
\text { Julho }\end{array}$ & $\begin{array}{c}\text { Média } \\
\text { Parcial }\end{array}$ & $\begin{array}{c}\text { Média } \\
\text { Total }\end{array}$ \\
\hline Ótimo & $34,15 \%$ & $68,42 \%$ & $40,00 \%$ & $42,86 \%$ & $46,36 \%$ & $46,36 \%$ \\
\hline Bom & $39,02 \%$ & $15,79 \%$ & $55,00 \%$ & $34,29 \%$ & $36,03 \%$ & $36,03 \%$ \\
\hline Regular & $7,32 \%$ & $10,53 \%$ & $0,00 \%$ & $8,57 \%$ & $6,61 \%$ & $6,61 \%$ \\
\hline Ruim & $2,44 \%$ & $0,00 \%$ & $0,00 \%$ & $0,00 \%$ & $0,61 \%$ & $0,61 \%$ \\
\hline Péssimo & $2,44 \%$ & $0,00 \%$ & $0,00 \%$ & $0,00 \%$ & $0,61 \%$ & $0,61 \%$ \\
\hline Total & $14,63 \%$ & $5,26 \%$ & $5,00 \%$ & $14,29 \%$ & $9,80 \%$ & $9,80 \%$ \\
\hline
\end{tabular}

Análise da Tabela 20: dos visitantes (62,09\%) que tiveram acesso aos guias e dos $(44,48 \%)$ que utilizaram os serviços dos guias, a maioria $(46,36 \%)$ classificaram os serviços em ótimo e $(36,03 \%)$ em bom. 


\section{Percepcão do Visitante}

\section{AVALIAÇÃO DA INFRA-ESTRUTURA}

Tabela 21 - Acesso ao município

\begin{tabular}{l|c|c|c|c|c|c}
\hline \multicolumn{1}{c}{ Variáveis } & $\begin{array}{c}\text { Semana } \\
\text { Santa }\end{array}$ & $\begin{array}{c}\text { Final de } \\
\text { Semana } \\
\text { Comum }\end{array}$ & $\begin{array}{c}\text { Festa do } \\
\text { Divino } \\
\text { Cavalhadas }\end{array}$ & $\begin{array}{c}\text { Férias de } \\
\text { Julho }\end{array}$ & $\begin{array}{c}\text { Média } \\
\text { Parcial }\end{array}$ & $\begin{array}{c}\text { Média } \\
\text { Total }\end{array}$ \\
\hline Ótimo & $24,75 \%$ & $24,11 \%$ & $26,35 \%$ & $25,00 \%$ & $25,05 \%$ & $25,05 \%$ \\
\hline Bom & $46,97 \%$ & $58,03 \%$ & $56,76 \%$ & $51,64 \%$ & $53,35 \%$ & $53,35 \%$ \\
\hline Regular & $10,35 \%$ & $8,93 \%$ & $6,76 \%$ & $7,57 \%$ & $8,40 \%$ & $8,40 \%$ \\
\hline Ruim & $2,52 \%$ & $0,89 \%$ & $0,00 \%$ & $1,32 \%$ & $1,18 \%$ & $1,18 \%$ \\
\hline Nássimo respondeu & $2,78 \%$ & $6,25 \%$ & $2,03 \%$ & $1,32 \%$ & $3,10 \%$ & $3,10 \%$ \\
\hline Total & $12,63 \%$ & $1,79 \%$ & $8,10 \%$ & $13,15 \%$ & $8,92 \%$ & $8,92 \%$ \\
\hline
\end{tabular}

Análise da Tabela 21: a maioria dos entrevistados (53,35\%) respondeu que o acesso ao município é bom e $(25,05 \%)$ disseram que é ótimo.

Tabela 22 - Sinalização nas rodovias

\begin{tabular}{l|c|c|c|c|c|c}
\hline \multicolumn{1}{c|}{ Variáveis } & $\begin{array}{c}\text { Semana } \\
\text { Santa }\end{array}$ & $\begin{array}{c}\text { Final de } \\
\text { Semana } \\
\text { Comum }\end{array}$ & $\begin{array}{c}\text { Festa do } \\
\text { Divino } \\
\text { Cavalhadas }\end{array}$ & $\begin{array}{c}\text { Férias de } \\
\text { Julho }\end{array}$ & $\begin{array}{c}\text { Média } \\
\text { Parcial }\end{array}$ & $\begin{array}{c}\text { Média } \\
\text { Total }\end{array}$ \\
\hline Ótimo & $6,06 \%$ & $5,36 \%$ & $8,11 \%$ & $7,57 \%$ & $6,78 \%$ & $6,78 \%$ \\
\hline Bom & $36,11 \%$ & $32,14 \%$ & $31,08 \%$ & $34,54 \%$ & $33,47 \%$ & $33,47 \%$ \\
\hline Regular & $23,74 \%$ & $26,79 \%$ & $29,73 \%$ & $24,34 \%$ & $26,15 \%$ & $26,15 \%$ \\
\hline Ruim & $9,85 \%$ & $13,39 \%$ & $7,43 \%$ & $7,89 \%$ & $9,64 \%$ & $9,64 \%$ \\
\hline Não resimo & $8,59 \%$ & $12,50 \%$ & $6,08 \%$ & $8,55 \%$ & $8,93 \%$ & $8,93 \%$ \\
\hline Total & $15,65 \%$ & $9,82 \%$ & $17,57 \%$ & $17,11 \%$ & $15,04 \%$ & $15,04 \%$ \\
\hline
\end{tabular}

Analise da Tabela 22: a sinalização das rodovias foi considerada pelos entrevistados como boa $(33,47 \%)$, seguida da opção regular $(26,15 \%)$.

Tabela 23 - Sinalização dentro do município

\begin{tabular}{l|c|c|c|c|c|c}
\hline \multicolumn{1}{c}{ Variáveis } & $\begin{array}{c}\text { Semana } \\
\text { Santa }\end{array}$ & $\begin{array}{c}\text { Final de } \\
\text { Semana } \\
\text { Comum }\end{array}$ & $\begin{array}{c}\text { Festa do } \\
\text { Divino } \\
\text { Cavalhadas }\end{array}$ & $\begin{array}{c}\text { Férias de } \\
\text { Julho }\end{array}$ & $\begin{array}{c}\text { Média } \\
\text { Parcial }\end{array}$ & $\begin{array}{c}\text { Média } \\
\text { Total }\end{array}$ \\
\hline Ótimo & - & $5,36 \%$ & $5,41 \%$ & $4,93 \%$ & $5,23 \%$ & $5,23 \%$ \\
\hline Bom & - & $34,82 \%$ & $34,46 \%$ & $34,54 \%$ & $34,61 \%$ & $34,61 \%$ \\
\hline Regular & - & $26,79 \%$ & $18,92 \%$ & $27,63 \%$ & $24,45 \%$ & $24,45 \%$ \\
\hline Ruim & - & $15,18 \%$ & $8,11 \%$ & $9,87 \%$ & $11,05 \%$ & $11,05 \%$ \\
\hline Nássimo respondeu & - & $4,46 \%$ & $10,14 \%$ & $3,95 \%$ & $6,18 \%$ & $6,18 \%$ \\
\hline Total & - & $13,39 \%$ & $22,97 \%$ & $19,08 \%$ & $18,48 \%$ & $18,48 \%$ \\
\hline
\end{tabular}

(-) Sem resposta - não foi perguntado na Semana Santa 
Análise da Tabela 23: a sinalização dentro do município nas três ocasiões pesquisadas foi considerada boa $(34,61 \%)$.

Tabela 24 - Aparência da Cidade

\begin{tabular}{l|c|c|c|c|c|c}
\hline \multicolumn{1}{c}{ Variáveis } & $\begin{array}{c}\text { Semana } \\
\text { Santa }\end{array}$ & $\begin{array}{c}\text { Final de } \\
\text { Semana } \\
\text { Comum }\end{array}$ & $\begin{array}{c}\text { Festa do } \\
\text { Divino } \\
\text { Cavalhadas }\end{array}$ & $\begin{array}{c}\text { Férias de } \\
\text { Julho }\end{array}$ & $\begin{array}{c}\text { Média } \\
\text { Parcial }\end{array}$ & $\begin{array}{c}\text { Média } \\
\text { Total }\end{array}$ \\
\hline Ótimo & $36,87 \%$ & $41,96 \%$ & $40,54 \%$ & $41,78 \%$ & $40,29 \%$ & $40,29 \%$ \\
\hline Bom & $42,42 \%$ & $44,65 \%$ & $40,54 \%$ & $40,46 \%$ & $42,02 \%$ & $42,02 \%$ \\
\hline Regular & $4,80 \%$ & $5,36 \%$ & $6,76 \%$ & $3,95 \%$ & $5,22 \%$ & $5,22 \%$ \\
\hline Puim & $0,25 \%$ & $0,89 \%$ & $0,68 \%$ & $0,33 \%$ & $0,54 \%$ & $0,54 \%$ \\
\hline Não respondeu & $0,25 \%$ & $0,00 \%$ & $0,68 \%$ & $0,00 \%$ & $0,23 \%$ & $0,23 \%$ \\
\hline Total & $15,41 \%$ & $7,14 \%$ & $10,80 \%$ & $13,48 \%$ & $11,70 \%$ & $11,70 \%$ \\
\hline
\end{tabular}

Análise da Tabela 24: a aparência da cidade foi considerada boa por $(42,02 \%)$ e ótima por (40,29\%) dos entrevistados, portanto podemos caracterizar Pirenópolis como sendo uma cidade muito aprazível para o turismo.

Tabela 25 - Limpeza urbana

\begin{tabular}{l|c|c|c|c|c|c}
\hline \multicolumn{1}{c}{ Variáveis } & $\begin{array}{c}\text { Semana } \\
\text { Santa }\end{array}$ & $\begin{array}{c}\text { Final de } \\
\text { Semana } \\
\text { Comum }\end{array}$ & $\begin{array}{c}\text { Festa do } \\
\text { Divino } \\
\text { Cavalhadas }\end{array}$ & $\begin{array}{c}\text { Férias de } \\
\text { Julho }\end{array}$ & $\begin{array}{c}\text { Média } \\
\text { Parcial }\end{array}$ & $\begin{array}{c}\text { Média } \\
\text { Total }\end{array}$ \\
\hline Ótimo & $14,90 \%$ & $19,65 \%$ & $16,22 \%$ & $31,25 \%$ & $20,51 \%$ & $20,51 \%$ \\
\hline Bom & $51,01 \%$ & $53,57 \%$ & $50,68 \%$ & $43,09 \%$ & $49,59 \%$ & $49,59 \%$ \\
\hline Regular & $12,88 \%$ & $13,39 \%$ & $15,54 \%$ & $8,88 \%$ & $12,67 \%$ & $12,67 \%$ \\
\hline Ruim & $5,05 \%$ & $3,57 \%$ & $5,41 \%$ & $0,99 \%$ & $3,76 \%$ & $3,76 \%$ \\
\hline Nássimo respondeu & $1,77 \%$ & $4,46 \%$ & $2,70 \%$ & $1,32 \%$ & $2,56 \%$ & $2,56 \%$ \\
\hline Total & $14,39 \%$ & $5,36 \%$ & $9,45 \%$ & $14,47 \%$ & $10,91 \%$ & $10,91 \%$ \\
\hline
\end{tabular}

Análise da Tabela 25: a limpeza da cidade foi considerada boa por 49,59\% dos entrevistados. 
Tabela 26 - Latões de Lixo

\begin{tabular}{l|c|c|c|c|c|c}
\hline \multicolumn{1}{c|}{ Variáveis } & $\begin{array}{c}\text { Semana } \\
\text { Santa }\end{array}$ & $\begin{array}{c}\text { Final de } \\
\text { Semana } \\
\text { Comum }\end{array}$ & $\begin{array}{c}\text { Festa do } \\
\text { Divino } \\
\text { Cavalhadas }\end{array}$ & $\begin{array}{c}\text { Férias de } \\
\text { Julho }\end{array}$ & $\begin{array}{c}\text { Média } \\
\text { Parcial }\end{array}$ & $\begin{array}{c}\text { Média } \\
\text { Total }\end{array}$ \\
\hline Ótimo & $2,53 \%$ & $5,36 \%$ & $8,78 \%$ & $8,22 \%$ & $6,22 \%$ & $6,22 \%$ \\
\hline Bom & $15,66 \%$ & $13,39 \%$ & $22,30 \%$ & $28,95 \%$ & $20,08 \%$ & $20,08 \%$ \\
\hline Regular & $29,29 \%$ & $19,64 \%$ & $25,00 \%$ & $17,11 \%$ & $22,76 \%$ & $22,76 \%$ \\
\hline Ruim & $18,18 \%$ & $10,71 \%$ & $9,46 \%$ & $5,92 \%$ & $11,07 \%$ & $11,07 \%$ \\
\hline Péssimo & $12,88 \%$ & $17,86 \%$ & $0,01 \%$ & $0,00 \%$ & $7,69 \%$ & $7,69 \%$ \\
\hline Tão respondeu & $21,46 \%$ & $33,04 \%$ & $34,45 \%$ & $39,80 \%$ & $32,18 \%$ & $32,18 \%$ \\
\hline
\end{tabular}

Análise da Tabela 26: a maioria dos entrevistados (32,18\%) não respondeu, más 22,76\% dos que responderam consideraram regular a quantidade de latões de lixo pela cidade.

Tabela 27 - Iluminação pública

\begin{tabular}{l|c|c|c|c|c|c}
\hline \multicolumn{1}{c}{ Variáveis } & $\begin{array}{c}\text { Semana } \\
\text { Santa }\end{array}$ & $\begin{array}{c}\text { Final de } \\
\text { Semana } \\
\text { Comum }\end{array}$ & $\begin{array}{c}\text { Festa do } \\
\text { Divino } \\
\text { Cavalhadas }\end{array}$ & $\begin{array}{c}\text { Férias de } \\
\text { Julho }\end{array}$ & $\begin{array}{c}\text { Média } \\
\text { Parcial }\end{array}$ & $\begin{array}{c}\text { Média } \\
\text { Total }\end{array}$ \\
\hline Ótimo & $29,80 \%$ & $31,25 \%$ & $31,08 \%$ & $29,61 \%$ & $30,43 \%$ & $30,43 \%$ \\
\hline Bom & $38,38 \%$ & $35,71 \%$ & $37,16 \%$ & $36,51 \%$ & $36,94 \%$ & $36,94 \%$ \\
\hline Regular & $10,61 \%$ & $1,79 \%$ & $9,46 \%$ & $3,62 \%$ & $6,37 \%$ & $6,37 \%$ \\
\hline Ruim & $1,52 \%$ & $2,68 \%$ & $1,35 \%$ & $0,99 \%$ & $1,64 \%$ & $1,64 \%$ \\
\hline Péssimo & $0,25 \%$ & $0,89 \%$ & $0,00 \%$ & $0,00 \%$ & $0,29 \%$ & $0,29 \%$ \\
\hline Total respondeu & $19,44 \%$ & $27,68 \%$ & $20,95 \%$ & $29,27 \%$ & $24,33 \%$ & $24,33 \%$ \\
\hline
\end{tabular}

Análise da Tabela 27: A iluminação pública foi considerada boa por 36,94\% e ótima por $30,43 \%$ dos entrevistados que responderam esta pergunta.

TABELA 28 - Serviço de telefonia

\begin{tabular}{l|c|c|c|c|c|c}
\hline \multicolumn{1}{c}{ Variáveis } & $\begin{array}{c}\text { Semana } \\
\text { Santa }\end{array}$ & $\begin{array}{c}\text { Final de } \\
\text { Semana } \\
\text { Comum }\end{array}$ & $\begin{array}{c}\text { Festa do } \\
\text { Divino } \\
\text { Cavalhadas }\end{array}$ & $\begin{array}{c}\text { Férias de } \\
\text { Julho }\end{array}$ & $\begin{array}{c}\text { Média } \\
\text { Parcial }\end{array}$ & $\begin{array}{c}\text { Média } \\
\text { Total }\end{array}$ \\
\hline Ótimo & - & $14,74 \%$ & $15,20 \%$ & $16,12 \%$ & $15,35 \%$ & $15,35 \%$ \\
\hline Bom & - & $26,78 \%$ & $25,67 \%$ & $29,61 \%$ & $27,35 \%$ & $27,35 \%$ \\
\hline Regular & - & $7,14 \%$ & $10,47 \%$ & $5,26 \%$ & $7,62 \%$ & $7,62 \%$ \\
\hline Ruim & - & $1,78 \%$ & $1,69 \%$ & $0,99 \%$ & $1,49 \%$ & $1,49 \%$ \\
\hline Néssimo rãospondeu & - & $1,34 \%$ & $1,02 \%$ & $1,32 \%$ & $1,23 \%$ & $1,23 \%$ \\
\hline Total & - & $48,22 \%$ & $45,95 \%$ & $46,71 \%$ & $46,96 \%$ & $46,96 \%$ \\
\hline
\end{tabular}

Análise da Tabela 28: esta pergunta não foi feita na Semana Santa e no Final de Semana Comum e Festa do Divino foi fraguimentada em duas perguntas (Serviço de telefone público e 
telefone celular). Más, para efeito de resposta sobre o serviço de telefonia 46,96\% não respondeu e $27,35 \%$ responderam que considera bom o serviço.

Tabela 29 - Serviço de transporte de uso público

\begin{tabular}{l|c|c|c|c|c|c}
\hline \multicolumn{1}{c}{ Variáveis } & $\begin{array}{c}\text { Semana } \\
\text { Santa }\end{array}$ & $\begin{array}{c}\text { Final de } \\
\text { Semana } \\
\text { Comum }\end{array}$ & $\begin{array}{c}\text { Festa do } \\
\text { Divino } \\
\text { Cavalhadas }\end{array}$ & $\begin{array}{c}\text { Férias de } \\
\text { Julho }\end{array}$ & $\begin{array}{c}\text { Média } \\
\text { Parcial }\end{array}$ & $\begin{array}{c}\text { Média } \\
\text { Total }\end{array}$ \\
\hline Ótimo & - & $1,79 \%$ & $0,00 \%$ & $0,66 \%$ & $0,82 \%$ & $0,82 \%$ \\
\hline Bom & - & $4,46 \%$ & $6,08 \%$ & $3,29 \%$ & $4,61 \%$ & $4,61 \%$ \\
\hline Regular & - & $1,79 \%$ & $4,05 \%$ & $2,63 \%$ & $2,82 \%$ & $2,82 \%$ \\
\hline Ruim & - & $1,79 \%$ & $0,00 \%$ & $0,66 \%$ & $0,82 \%$ & $0,82 \%$ \\
\hline Néssimo & - & $1,79 \%$ & $0,68 \%$ & $1,32 \%$ & $1,26 \%$ & $1,26 \%$ \\
\hline Total & - & $88,38 \%$ & $89,19 \%$ & $91,45 \%$ & $89,67 \%$ & $89,67 \%$ \\
\hline
\end{tabular}

Análise da Tabela 29: esta pergunta não consta no questionário da Semana Santa. E, 89,97\% dos entrevistados não responderam tal pergunta nas outras três ocasiões.

Tabela 30 - Segurança

\begin{tabular}{l|c|c|c|c|c|c}
\hline \multicolumn{1}{c}{ Variáveis } & $\begin{array}{c}\text { Semana } \\
\text { Santa }\end{array}$ & $\begin{array}{c}\text { Final de } \\
\text { Semana } \\
\text { Comum }\end{array}$ & $\begin{array}{c}\text { Festa do } \\
\text { Divino } \\
\text { Cavalhadas }\end{array}$ & $\begin{array}{c}\text { Férias de } \\
\text { Julho }\end{array}$ & $\begin{array}{c}\text { Média } \\
\text { Parcial }\end{array}$ & $\begin{array}{c}\text { Média } \\
\text { Total }\end{array}$ \\
\hline Ótimo & $21,21 \%$ & $16,07 \%$ & $21,62 \%$ & $16,84 \%$ & $18,94 \%$ & $18,94 \%$ \\
\hline Bom & $48,74 \%$ & $43,75 \%$ & $49,32 \%$ & $31,32 \%$ & $43,28 \%$ & $43,28 \%$ \\
\hline Regular & $10,10 \%$ & $6,25 \%$ & $15,54 \%$ & $11,91 \%$ & $10,95 \%$ & $10,95 \%$ \\
\hline Ruim & $2,02 \%$ & $5,36 \%$ & $0,68 \%$ & $7,30 \%$ & $3,84 \%$ & $3,84 \%$ \\
\hline Néssimo & $1,26 \%$ & $1,79 \%$ & $2,03 \%$ & $5,66 \%$ & $2,69 \%$ & $2,69 \%$ \\
\hline Total & $16,67 \%$ & $26,78 \%$ & $10,81 \%$ & $26,97 \%$ & $20,30 \%$ & $20,30 \%$ \\
\hline
\end{tabular}

Análise da Tabela 30: a segurança em Pirenópolis foi considerada boa por 43,28\% dos entrevistados e ótimos por $18,94 \%$, más $20,30 \%$ não responderam esta questão. 
Tabela 31 - Serviços médicos / hospitalares

\begin{tabular}{l|c|c|c|c|c|c}
\hline \multicolumn{1}{c}{ Variáveis } & $\begin{array}{c}\text { Semana } \\
\text { Santa }\end{array}$ & $\begin{array}{c}\text { Final de } \\
\text { Semana } \\
\text { Comum }\end{array}$ & $\begin{array}{c}\text { Festa do } \\
\text { Divino } \\
\text { Cavalhadas }\end{array}$ & $\begin{array}{c}\text { Férias de } \\
\text { Julho }\end{array}$ & $\begin{array}{c}\text { Média } \\
\text { Parcial }\end{array}$ & $\begin{array}{c}\text { Média } \\
\text { Total }\end{array}$ \\
\hline Ótimo & $2,02 \%$ & $1,79 \%$ & $1,35 \%$ & $0,00 \%$ & $1,29 \%$ & $1,29 \%$ \\
\hline Bom & $10,35 \%$ & $2,68 \%$ & $6,08 \%$ & $5,59 \%$ & $6,18 \%$ & $6,18 \%$ \\
\hline Regular & $9,85 \%$ & $11,61 \%$ & $6,08 \%$ & $1,97 \%$ & $7,38 \%$ & $7,38 \%$ \\
\hline Ruim & $3,79 \%$ & $2,68 \%$ & $0,00 \%$ & $0,33 \%$ & $1,70 \%$ & $1,70 \%$ \\
\hline Néssimo & $1,52 \%$ & $4,46 \%$ & $2,70 \%$ & $0,66 \%$ & $2,33 \%$ & $2,33 \%$ \\
\hline Total & $72,47 \%$ & $76,78 \%$ & $83,79 \%$ & $91,45 \%$ & $81,12 \%$ & $81,12 \%$ \\
\hline
\end{tabular}

Análise da Tabela 31: a maioria de $81,12 \%$ dos entrevistados não respondeu esta questão e dos $18,88 \%$ que responderam, $7,38 \%$ consideraram regular.

\section{$\underline{\text { AVALIACCÃO DOS ATRATIVOS }}$}

Tabela 32 - Acesso aos atrativos

\begin{tabular}{l|c|c|c|c|c|c}
\hline \multicolumn{1}{c}{ Variáveis } & $\begin{array}{c}\text { Semana } \\
\text { Santa }\end{array}$ & $\begin{array}{c}\text { Final de } \\
\text { Semana } \\
\text { Comum }\end{array}$ & $\begin{array}{c}\text { Festa do } \\
\text { Divino } \\
\text { Cavalhadas }\end{array}$ & $\begin{array}{c}\text { Férias de } \\
\text { Julho }\end{array}$ & $\begin{array}{c}\text { Média } \\
\text { Parcial }\end{array}$ & $\begin{array}{c}\text { Média } \\
\text { Total }\end{array}$ \\
\hline Ótimo & $9,09 \%$ & $11,61 \%$ & $12,84 \%$ & $10,20 \%$ & $10,94 \%$ & $10,94 \%$ \\
\hline Bom & $39,14 \%$ & $40,18 \%$ & $37,84 \%$ & $27,96 \%$ & $36,28 \%$ & $36,28 \%$ \\
\hline Regular & $21,97 \%$ & $14,29 \%$ & $9,46 \%$ & $17,43 \%$ & $15,79 \%$ & $15,79 \%$ \\
\hline Ruim & $7,58 \%$ & $6,25 \%$ & $5,41 \%$ & $4,61 \%$ & $5,96 \%$ & $5,96 \%$ \\
\hline Péssimo & $3,54 \%$ & $2,67 \%$ & $5,41 \%$ & $1,97 \%$ & $3,39 \%$ & $3,39 \%$ \\
\hline Total respondeu & $18,68 \%$ & $25,00 \%$ & $29,04 \%$ & $37,83 \%$ & $27,64 \%$ & $27,64 \%$ \\
\hline & $100 \%$ & $100 \%$ & $100 \%$ & $100 \%$ & $100 \%$ & $100 \%$ \\
\hline
\end{tabular}

Análise da Tabela 32: o acesso aos atrativos foi considerado bom por 36,28\% dos entrevistados e regular por $15,79 \%$, más $27,64 \%$ não responderam esta questão.

Tabela 33 - Sinalização até os atrativos

\begin{tabular}{l|c|c|c|c|c|c}
\hline \multicolumn{1}{c|}{ Variáveis } & $\begin{array}{c}\text { Semana } \\
\text { Santa }\end{array}$ & $\begin{array}{c}\text { Final de } \\
\text { Semana } \\
\text { Comum }\end{array}$ & $\begin{array}{c}\text { Festa do } \\
\text { Divino } \\
\text { Cavalhadas }\end{array}$ & $\begin{array}{c}\text { Férias de } \\
\text { Julho }\end{array}$ & $\begin{array}{c}\text { Média } \\
\text { Parcial }\end{array}$ & $\begin{array}{c}\text { Média } \\
\text { Total }\end{array}$ \\
\hline Ótimo & - & $4,46 \%$ & $4,73 \%$ & $3,29 \%$ & $4,17 \%$ & $4,17 \%$ \\
\hline Bom & - & $23,21 \%$ & $14,86 \%$ & $20,07 \%$ & $19,38 \%$ & $19,38 \%$ \\
\hline Regular & - & $18,75 \%$ & $17,57 \%$ & $20,39 \%$ & $18,90 \%$ & $18,90 \%$ \\
\hline Ruim & - & $10,72 \%$ & $9,46 \%$ & $11,84 \%$ & $10,67 \%$ & $10,67 \%$ \\
\hline Péssimo & - & $7,14 \%$ & $7,43 \%$ & $5,26 \%$ & $6,61 \%$ & $6,61 \%$ \\
\hline Total respondeu & - & $35,72 \%$ & $45,95 \%$ & $39,14 \%$ & $40,27 \%$ & $40,27 \%$ \\
\hline
\end{tabular}


Análise da Tabela 33: esta pergunta não consta no questionário da Semana Santa. 40,27\% dos entrevistados nas outras três ocasiões não responderam e 19,38\% consideraram a sinalização até os atrativos boa e $18,90 \%$ consideraram regular.

Tabela 34 - Sinalização dentro dos atrativos

\begin{tabular}{l|c|c|c|c|c|c}
\hline \multicolumn{1}{c}{ Variáveis } & $\begin{array}{c}\text { Semana } \\
\text { Santa }\end{array}$ & $\begin{array}{c}\text { Final de } \\
\text { Semana } \\
\text { Comum }\end{array}$ & $\begin{array}{c}\text { Festa do } \\
\text { Divino } \\
\text { Cavalhadas }\end{array}$ & $\begin{array}{c}\text { Férias de } \\
\text { Julho }\end{array}$ & $\begin{array}{c}\text { Média } \\
\text { Parcial }\end{array}$ & $\begin{array}{c}\text { Média } \\
\text { Total }\end{array}$ \\
\hline Ótimo & $6,31 \%$ & $6,25 \%$ & $6,08 \%$ & $4,48 \%$ & $5,78 \%$ & $5,78 \%$ \\
\hline Bom & $29,04 \%$ & $22,32 \%$ & $16,22 \%$ & $21,47 \%$ & $22,26 \%$ & $22,26 \%$ \\
\hline Regular & $26,26 \%$ & $18,75 \%$ & $13,51 \%$ & $16,21 \%$ & $18,68 \%$ & $18,68 \%$ \\
\hline Ruim & $11,87 \%$ & $6,25 \%$ & $6,08 \%$ & $5,68 \%$ & $7,47 \%$ & $7,47 \%$ \\
\hline Nássimo respondeu & $6,06 \%$ & $5,36 \%$ & $8,11 \%$ & $5,02 \%$ & $6,14 \%$ & $6,14 \%$ \\
\hline Total & $20,46 \%$ & $41,07 \%$ & $50,00 \%$ & $47,13 \%$ & $39,67 \%$ & $39,67 \%$ \\
\hline
\end{tabular}

Análise da Tabela 34: a sinalização dentro dos atrativos foi considerada por $22,26 \%$ dos entrevistados que responderam boa e regular por 18,68\%. Más, 39,67\% não responderam.

Tabela 35 - Limpeza dos atrativos

\begin{tabular}{l|c|c|c|c|c|c}
\hline \multicolumn{1}{c}{ Variáveis } & $\begin{array}{c}\text { Semana } \\
\text { Santa }\end{array}$ & $\begin{array}{c}\text { Final de } \\
\text { Semana } \\
\text { Comum }\end{array}$ & $\begin{array}{c}\text { Festa do } \\
\text { Divino } \\
\text { Cavalhadas }\end{array}$ & $\begin{array}{c}\text { Férias de } \\
\text { Julho }\end{array}$ & $\begin{array}{c}\text { Média } \\
\text { Parcial }\end{array}$ & $\begin{array}{c}\text { Média } \\
\text { Total }\end{array}$ \\
\hline Ótimo & $14,65 \%$ & $14,29 \%$ & $11,49 \%$ & $10,20 \%$ & $12,66 \%$ & $12,66 \%$ \\
\hline Bom & $45,45 \%$ & $37,50 \%$ & $27,03 \%$ & $30,59 \%$ & $35,14 \%$ & $35,14 \%$ \\
\hline Regular & $13,38 \%$ & $11,61 \%$ & $10,81 \%$ & $12,17 \%$ & $11,99 \%$ & $11,99 \%$ \\
\hline Puim & $3,79 \%$ & $0,89 \%$ & $3,38 \%$ & $2,30 \%$ & $2,59 \%$ & $2,59 \%$ \\
\hline Não respondeu & $1,52 \%$ & $1,79 \%$ & $6,08 \%$ & $1,32 \%$ & $2,68 \%$ & $2,68 \%$ \\
\hline Total & $21,21 \%$ & $33,92 \%$ & $41,21 \%$ & $43,42 \%$ & $34,94 \%$ & $34,94 \%$ \\
\hline Amalim & $100 \%$ & $100 \%$ & $100 \%$ & $100 \%$ & $100 \%$ & $100 \%$ \\
\hline
\end{tabular}

Análise da Tabela 35: a limpeza dos atrativos foi considerada boa por $35,14 \%$ dos entrevistados que responderam, pois $34,94 \%$ não responderam.

Tabela 36 - Patrimônio histórico

\begin{tabular}{l|c|c|c|c|c|c}
\hline \multicolumn{1}{c|}{ Variáveis } & $\begin{array}{c}\text { Semana } \\
\text { Santa }\end{array}$ & $\begin{array}{c}\text { Final de } \\
\text { Semana } \\
\text { Comum }\end{array}$ & $\begin{array}{c}\text { Festa do } \\
\text { Divino } \\
\text { Cavalhadas }\end{array}$ & $\begin{array}{c}\text { Férias de } \\
\text { Julho }\end{array}$ & $\begin{array}{c}\text { Média } \\
\text { Parcial }\end{array}$ & $\begin{array}{c}\text { Média } \\
\text { Total }\end{array}$ \\
\hline Ótimo & $26,52 \%$ & $20,54 \%$ & $23,65 \%$ & $27,30 \%$ & $24,49 \%$ & $24,49 \%$ \\
\hline Bom & $46,21 \%$ & $39,29 \%$ & $32,43 \%$ & $35,20 \%$ & $38,27 \%$ & $38,27 \%$ \\
\hline Regular & $6,31 \%$ & $10,71 \%$ & $6,76 \%$ & $4,28 \%$ & $7,05 \%$ & $7,05 \%$ \\
\hline Ruim & $1,26 \%$ & $1,79 \%$ & $2,70 \%$ & $1,64 \%$ & $1,84 \%$ & $1,84 \%$ \\
\hline Péssimo & $0,51 \%$ & $1,79 \%$ & $0,00 \%$ & $0,00 \%$ & $0,58 \%$ & $0,58 \%$ \\
\hline Não respondeu & $19,19 \%$ & $25,88 \%$ & $34,46 \%$ & $31,58 \%$ & $27,77 \%$ & $27,77 \%$ \\
\hline Total & $100 \%$ & $100 \%$ & $100 \%$ & $100 \%$ & $100 \%$ & $100 \%$ \\
\hline
\end{tabular}


Análise da Tabela 36: o patrimônio histórico do município de Pirenópolis foi considerado bom por $38,27 \%$ e ótimo por $24,49 \%$ dos entrevistados que responderam esta questão.Visto que, $27,77 \%$ dos entrevistados não responderam esta questão.

Tabela 37 - Matas

\begin{tabular}{l|c|c|c|c|c|c}
\hline \multicolumn{1}{c|}{ Variáveis } & $\begin{array}{c}\text { Semana } \\
\text { Santa }\end{array}$ & $\begin{array}{c}\text { Final de } \\
\text { Semana } \\
\text { Comum }\end{array}$ & $\begin{array}{c}\text { Festa do } \\
\text { Divino } \\
\text { Cavalhadas }\end{array}$ & $\begin{array}{c}\text { Férias de } \\
\text { Julho }\end{array}$ & $\begin{array}{c}\text { Média } \\
\text { Parcial }\end{array}$ & $\begin{array}{c}\text { Média } \\
\text { Total }\end{array}$ \\
\hline Ótimo & - & $15,18 \%$ & $18,24 \%$ & $16,78 \%$ & $16,73 \%$ & $16,73 \%$ \\
\hline Bom & - & $31,25 \%$ & $20,95 \%$ & $22,37 \%$ & $24,86 \%$ & $24,86 \%$ \\
\hline Regular & - & $6,25 \%$ & $8,11 \%$ & $5,92 \%$ & $6,76 \%$ & $6,76 \%$ \\
\hline Ruim & - & $0,00 \%$ & $1,35 \%$ & $0,99 \%$ & $0,78 \%$ & $0,78 \%$ \\
\hline Néssimo & - & $0,00 \%$ & $0,00 \%$ & $0,66 \%$ & $0,22 \%$ & $0,22 \%$ \\
\hline Toto respondeu & - & $47,32 \%$ & $51,35 \%$ & $53,29 \%$ & $50,65 \%$ & $50,65 \%$ \\
\hline
\end{tabular}

Análise da Tabela 37: 50,65\% dos entrevistados não responderam esta questão, más dos que responderam $24,86 \%$ consideraram as matas em boas condições.

Tabela 38 - Rios/cachoeiras/lagos

\begin{tabular}{l|c|c|c|c|c|c}
\hline \multicolumn{1}{c}{ Variáveis } & $\begin{array}{c}\text { Semana } \\
\text { Santa }\end{array}$ & $\begin{array}{c}\text { Final de } \\
\text { Semana } \\
\text { Comum }\end{array}$ & $\begin{array}{c}\text { Festa do } \\
\text { Divino } \\
\text { Cavalhadas }\end{array}$ & $\begin{array}{c}\text { Férias de } \\
\text { Julho }\end{array}$ & $\begin{array}{c}\text { Média } \\
\text { Parcial }\end{array}$ & $\begin{array}{c}\text { Média } \\
\text { Total }\end{array}$ \\
\hline Ótimo & - & $27,68 \%$ & $27,03 \%$ & $31,25 \%$ & $28,64 \%$ & $28,64 \%$ \\
\hline Bom & - & $25,89 \%$ & $22,97 \%$ & $18,42 \%$ & $22,46 \%$ & $22,46 \%$ \\
\hline Regular & - & $3,58 \%$ & $3,38 \%$ & $2,30 \%$ & $3,08 \%$ & $3,08 \%$ \\
\hline Ruim & - & $0,89 \%$ & $0,00 \%$ & $0,33 \%$ & $0,40 \%$ & $0,40 \%$ \\
\hline Néssimo rão respondeu & - & $0,00 \%$ & $0,00 \%$ & $0,00 \%$ & $0,00 \%$ & $0,00 \%$ \\
\hline Total & - & $41,96 \%$ & $46,62 \%$ & $47,70 \%$ & $45,42 \%$ & $45,42 \%$ \\
\hline
\end{tabular}

Análise da Tabela 38: 45,42\% dos entrevistados não responderam esta questão, más 28,64\% dos que responderam consideraram os rios, cachoeiras e lagos ótimos e 22,46\% bom. 
Tabela 39 - Monumentos

\begin{tabular}{l|c|c|c|c|c|c}
\hline \multicolumn{1}{c|}{ Variáveis } & $\begin{array}{c}\text { Semana } \\
\text { Santa }\end{array}$ & $\begin{array}{c}\text { Final de } \\
\text { Semana } \\
\text { Comum }\end{array}$ & $\begin{array}{c}\text { Festa do } \\
\text { Divino } \\
\text { Cavalhadas }\end{array}$ & $\begin{array}{c}\text { Férias de } \\
\text { Julho }\end{array}$ & $\begin{array}{c}\text { Média } \\
\text { Parcial }\end{array}$ & $\begin{array}{c}\text { Média } \\
\text { Total }\end{array}$ \\
\hline Ótimo & - & $11,61 \%$ & $14,19 \%$ & $8,55 \%$ & $11,45 \%$ & $11,45 \%$ \\
\hline Bom & - & $21,43 \%$ & $25,68 \%$ & $16,12 \%$ & $21,07 \%$ & $21,07 \%$ \\
\hline Regular & - & $8,92 \%$ & $4,73 \%$ & $2,96 \%$ & $5,54 \%$ & $5,54 \%$ \\
\hline Ruim & - & $5,36 \%$ & $1,35 \%$ & $0,66 \%$ & $2,46 \%$ & $2,46 \%$ \\
\hline Péssimo & - & $0,89 \%$ & $0,68 \%$ & $0,33 \%$ & $0,63 \%$ & $0,63 \%$ \\
\hline Tão respondeu & - & $51,79 \%$ & $53,38 \%$ & $71,38 \%$ & $58,85 \%$ & $58,85 \%$ \\
\hline
\end{tabular}

Análise da Tabela 39: na Semana Santa esta questão não foi perguntada, más nos outros três momentos $21,07 \%$ dos turistas que responderam consideraram os monumentos bons.

Tabela 40 - Cavernas/grutas/serras/morros

\begin{tabular}{l|c|c|c|c|c|c}
\hline \multicolumn{1}{c}{ Variáveis } & $\begin{array}{c}\text { Semana } \\
\text { Santa }\end{array}$ & $\begin{array}{c}\text { Final de } \\
\text { Semana } \\
\text { Comum }\end{array}$ & $\begin{array}{c}\text { Festa do } \\
\text { Divino } \\
\text { Cavalhadas }\end{array}$ & $\begin{array}{c}\text { Férias de } \\
\text { Julho }\end{array}$ & $\begin{array}{c}\text { Média } \\
\text { Parcial }\end{array}$ & $\begin{array}{c}\text { Média } \\
\text { Total }\end{array}$ \\
\hline Ótimo & - & $7,14 \%$ & $14,19 \%$ & $4,93 \%$ & $8,75 \%$ & $8,75 \%$ \\
\hline Bom & - & $4,46 \%$ & $10,81 \%$ & $10,20 \%$ & $8,49 \%$ & $8,49 \%$ \\
\hline Regular & - & $1,79 \%$ & $2,70 \%$ & $1,32 \%$ & $1,94 \%$ & $1,94 \%$ \\
\hline Ruim & - & $0,89 \%$ & $0,00 \%$ & $0,00 \%$ & $0,30 \%$ & $0,30 \%$ \\
\hline Nássimo respondeu & - & $0,00 \%$ & $0,00 \%$ & $0,66 \%$ & $0,22 \%$ & $0,22 \%$ \\
\hline Total & - & $85,72 \%$ & $72,30 \%$ & $82,89 \%$ & $80,30 \%$ & $80,30 \%$ \\
\hline
\end{tabular}

Análise da Tabela 40: na Semana Santa esta questão não foi perguntada. $80,30 \%$ dos entrevistados não responderam e 8,75\% consideraram as cavernas, grutas, serras e morros como ótimos e $8,49 \%$ bom.

Tabela 41 - Segurança dos Atrativos

\begin{tabular}{l|c|c|c|c|c|c}
\hline \multicolumn{1}{c}{ Variáveis } & $\begin{array}{c}\text { Semana } \\
\text { Santa }\end{array}$ & $\begin{array}{c}\text { Final de } \\
\text { Semana } \\
\text { Comum }\end{array}$ & $\begin{array}{c}\text { Festa do } \\
\text { Divino } \\
\text { Cavalhadas }\end{array}$ & $\begin{array}{c}\text { Férias de } \\
\text { Julho }\end{array}$ & $\begin{array}{c}\text { Média } \\
\text { Parcial }\end{array}$ & $\begin{array}{c}\text { Média } \\
\text { Total }\end{array}$ \\
\hline Ótimo & - & - & - & $4,28 \%$ & $4,28 \%$ & $4,28 \%$ \\
\hline Bom & - & - & - & $20,72 \%$ & $20,72 \%$ & $20,72 \%$ \\
\hline Regular & - & - & - & $13,82 \%$ & $13,82 \%$ & $13,82 \%$ \\
\hline Ruim & - & - & - & $4,61 \%$ & $4,61 \%$ & $4,61 \%$ \\
\hline Péssimo & - & - & - & $2,30 \%$ & $2,30 \%$ & $2,30 \%$ \\
\hline Não respondeu & - & - & - & $54,28 \%$ & $54,28 \%$ & $54,28 \%$ \\
\hline Total & - & - & - & $100 \%$ & $100 \%$ & $100 \%$ \\
\hline
\end{tabular}


Análise da Tabela 41: esta pergunta só foi utilizada no questionário das Férias de Julho e a maioria de 54,28\% dos entrevistados não responderam tal questão e $20,72 \%$ consideraram a segurança dos atrativos boa.

\section{AVALIAÇÃO DOS EQUIPAMENTOS E SERVIÇOS TURÍSTICOS}

Tabela 42 - Hospedagem

\begin{tabular}{l|c|c|c|c|c|c}
\hline \multicolumn{1}{c|}{ Variáveis } & $\begin{array}{c}\text { Semana } \\
\text { Santa }\end{array}$ & $\begin{array}{c}\text { Final de } \\
\text { Semana } \\
\text { Comum }\end{array}$ & $\begin{array}{c}\text { Festa do } \\
\text { Divino } \\
\text { Cavalhadas }\end{array}$ & $\begin{array}{c}\text { Férias de } \\
\text { Julho }\end{array}$ & $\begin{array}{c}\text { Média } \\
\text { Parcial }\end{array}$ & $\begin{array}{c}\text { Média } \\
\text { Total }\end{array}$ \\
\hline Ótimo & $21,72 \%$ & $31,25 \%$ & $23,65 \%$ & $27,30 \%$ & $25,98 \%$ & $25,98 \%$ \\
\hline Bom & $40,40 \%$ & $39,29 \%$ & $26,35 \%$ & $38,16 \%$ & $36,05 \%$ & $36,05 \%$ \\
\hline Regular & $12,63 \%$ & $4,46 \%$ & $5,41 \%$ & $4,28 \%$ & $6,70 \%$ & $6,70 \%$ \\
\hline Ruim & $2,78 \%$ & $0,89 \%$ & $0,00 \%$ & $0,66 \%$ & $1,08 \%$ & $1,08 \%$ \\
\hline Péssimo & $1,52 \%$ & $0,89 \%$ & $0,00 \%$ & $0,33 \%$ & $0,68 \%$ & $0,68 \%$ \\
\hline Não respondeu & $20,95 \%$ & $23,22 \%$ & $44,59 \%$ & $29,27 \%$ & $29,51 \%$ & $29,51 \%$ \\
\hline Total & $100 \%$ & $100 \%$ & $100 \%$ & $100 \%$ & $100 \%$ & $100 \%$ \\
\hline
\end{tabular}

Análise da Tabela 42: a maioria de 36,05\% dos entrevistados que responderam sobre a hospedagem consideraram-na de boa qualidade e $25,98 \%$ ótima.

Tabela 43 - Alimentação

\begin{tabular}{l|c|c|c|c|c|c}
\hline \multicolumn{1}{c|}{ Variáveis } & $\begin{array}{c}\text { Semana } \\
\text { Santa }\end{array}$ & $\begin{array}{c}\text { Final de } \\
\text { Semana } \\
\text { Comum }\end{array}$ & $\begin{array}{c}\text { Festa do } \\
\text { Divino } \\
\text { Cavalhadas }\end{array}$ & $\begin{array}{c}\text { Férias de } \\
\text { Julho }\end{array}$ & $\begin{array}{c}\text { Média } \\
\text { Parcial }\end{array}$ & $\begin{array}{c}\text { Média } \\
\text { Total }\end{array}$ \\
\hline Ótimo & $27,02 \%$ & $31,25 \%$ & $33,78 \%$ & $30,92 \%$ & $30,74 \%$ & $30,74 \%$ \\
\hline Bom & $47,47 \%$ & $39,29 \%$ & $44,59 \%$ & $42,11 \%$ & $43,37 \%$ & $43,37 \%$ \\
\hline Regular & $8,08 \%$ & $4,47 \%$ & $6,76 \%$ & $5,26 \%$ & $6,14 \%$ & $6,14 \%$ \\
\hline Ruim & $0,76 \%$ & $0,89 \%$ & $0,68 \%$ & $0,33 \%$ & $0,67 \%$ & $0,67 \%$ \\
\hline Péssimo & $1,01 \%$ & $0,89 \%$ & $1,35 \%$ & $1,64 \%$ & $1,22 \%$ & $1,22 \%$ \\
\hline Total respondeu & $15,66 \%$ & $23,21 \%$ & $12,84 \%$ & $19,74 \%$ & $17,86 \%$ & $17,86 \%$ \\
\hline
\end{tabular}

Análise da Tabela 43: a alimentação foi considerada pela maioria de 43,37\% dos entrevistados como bom e 30,74\% como ótima. 
Tabela 44 - Informações

\begin{tabular}{l|c|c|c|c|c|c}
\hline \multicolumn{1}{c|}{ Variáveis } & $\begin{array}{c}\text { Semana } \\
\text { Santa }\end{array}$ & $\begin{array}{c}\text { Final de } \\
\text { Semana } \\
\text { Comum }\end{array}$ & $\begin{array}{c}\text { Festa do } \\
\text { Divino } \\
\text { Cavalhadas }\end{array}$ & $\begin{array}{c}\text { Férias de } \\
\text { Julho }\end{array}$ & $\begin{array}{c}\text { Média } \\
\text { Parcial }\end{array}$ & $\begin{array}{c}\text { Média } \\
\text { Total }\end{array}$ \\
\hline Ótimo & $18,94 \%$ & $21,43 \%$ & $26,35 \%$ & $22,04 \%$ & $22,19 \%$ & $22,19 \%$ \\
\hline Bom & $42,17 \%$ & $39,29 \%$ & $46,62 \%$ & $42,43 \%$ & $42,63 \%$ & $42,63 \%$ \\
\hline Regular & $15,40 \%$ & $8,93 \%$ & $8,78 \%$ & $10,53 \%$ & $10,91 \%$ & $10,91 \%$ \\
\hline Ruim & $4,29 \%$ & $6,25 \%$ & $2,03 \%$ & $0,99 \%$ & $3,39 \%$ & $3,39 \%$ \\
\hline Péssimo & $2,02 \%$ & $2,68 \%$ & $0,00 \%$ & $1,97 \%$ & $1,67 \%$ & $1,67 \%$ \\
\hline Não respondeu & $17,18 \%$ & $21,42 \%$ & $16,22 \%$ & $22,04 \%$ & $19,21 \%$ & $19,21 \%$ \\
\hline
\end{tabular}

Análise da Tabela 44: a obtenção de informações por parte dos visitantes foi considerada por $42,63 \%$ dos entrevistados como bom e $22,19 \%$ sendo ótima.

Tabela 45 - Hospitalidade

\begin{tabular}{l|c|c|c|c|c|c}
\hline \multicolumn{1}{c|}{ Variáveis } & $\begin{array}{c}\text { Semana } \\
\text { Santa }\end{array}$ & $\begin{array}{c}\text { Final de } \\
\text { Semana } \\
\text { Comum }\end{array}$ & $\begin{array}{c}\text { Festa do } \\
\text { Divino } \\
\text { Cavalhadas }\end{array}$ & $\begin{array}{c}\text { Férias de } \\
\text { Julho }\end{array}$ & $\begin{array}{c}\text { Média } \\
\text { Parcial }\end{array}$ & $\begin{array}{c}\text { Média } \\
\text { Total }\end{array}$ \\
\hline Ótimo & $38,13 \%$ & $55,36 \%$ & $42,57 \%$ & $41,12 \%$ & $44,29 \%$ & $44,29 \%$ \\
\hline Bom & $40,91 \%$ & $35,71 \%$ & $40,54 \%$ & $38,16 \%$ & $38,83 \%$ & $38,83 \%$ \\
\hline Regular & $4,04 \%$ & $1,79 \%$ & $3,38 \%$ & $1,97 \%$ & $2,80 \%$ & $2,80 \%$ \\
\hline Ruim & $0,51 \%$ & $0,89 \%$ & $0,68 \%$ & $0,33 \%$ & $0,60 \%$ & $0,60 \%$ \\
\hline Péssimo & $1,01 \%$ & $1,79 \%$ & $0,00 \%$ & $0,99 \%$ & $0,95 \%$ & $0,95 \%$ \\
\hline Não respondeu & $15,40 \%$ & $4,46 \%$ & $12,83 \%$ & $17,43 \%$ & $12,53 \%$ & $12,53 \%$ \\
\hline
\end{tabular}

Análise da Tabela 45: a hospitalidade de Pirenópolis foi considerada ótima por 44,29\% dos visitantes que responderam esta questão e boa por $38,83 \%$.

Tabela 46 - Atendimento

\begin{tabular}{l|c|c|c|c|c|c}
\hline \multicolumn{1}{c|}{ Variáveis } & $\begin{array}{c}\text { Semana } \\
\text { Santa }\end{array}$ & $\begin{array}{c}\text { Final de } \\
\text { Semana } \\
\text { Comum }\end{array}$ & $\begin{array}{c}\text { Festa do } \\
\text { Divino } \\
\text { Cavalhadas }\end{array}$ & $\begin{array}{c}\text { Férias de } \\
\text { Julho }\end{array}$ & $\begin{array}{c}\text { Média } \\
\text { Parcial }\end{array}$ & $\begin{array}{c}\text { Média } \\
\text { Total }\end{array}$ \\
\hline Ótimo & $23,23 \%$ & $27,68 \%$ & $32,43 \%$ & $31,25 \%$ & $28,65 \%$ & $28,65 \%$ \\
\hline Bom & $46,46 \%$ & $55,36 \%$ & $42,57 \%$ & $44,08 \%$ & $47,12 \%$ & $47,12 \%$ \\
\hline Regular & $11,87 \%$ & $10,71 \%$ & $12,16 \%$ & $6,91 \%$ & $10,41 \%$ & $10,41 \%$ \\
\hline Ruim & $2,02 \%$ & $0,89 \%$ & $0,68 \%$ & $0,66 \%$ & $1,06 \%$ & $1,06 \%$ \\
\hline Péssimo & $2,27 \%$ & $0,89 \%$ & $2,03 \%$ & $0,66 \%$ & $1,46 \%$ & $1,46 \%$ \\
\hline Tatal respondeu & $14,15 \%$ & $4,47 \%$ & $10,13 \%$ & $16,44 \%$ & $11,30 \%$ & $11,30 \%$ \\
\hline
\end{tabular}


Análise da Tabela 46: 47,12\% dos visitantes que responderam esta questão consideraram o atendimento dos serviços turísticos como sendo ótimo e $28,65 \%$ bom.

Tabela 47 - Entretenimentos

\begin{tabular}{l|c|c|c|c|c|c}
\hline \multicolumn{1}{c|}{ Variáveis } & $\begin{array}{c}\text { Semana } \\
\text { Santa }\end{array}$ & $\begin{array}{c}\text { Final de } \\
\text { Semana } \\
\text { Comum }\end{array}$ & $\begin{array}{c}\text { Festa do } \\
\text { Divino } \\
\text { Cavalhadas }\end{array}$ & $\begin{array}{c}\text { Férias de } \\
\text { Julho }\end{array}$ & $\begin{array}{c}\text { Média } \\
\text { Parcial }\end{array}$ & $\begin{array}{c}\text { Média } \\
\text { Total }\end{array}$ \\
\hline Ótimo & $15,15 \%$ & $17,86 \%$ & $23,65 \%$ & $19,41 \%$ & $19,02 \%$ & $19,02 \%$ \\
\hline Bom & $36,87 \%$ & $43,75 \%$ & $40,54 \%$ & $34,54 \%$ & $38,92 \%$ & $38,92 \%$ \\
\hline Regular & $21,46 \%$ & $8,93 \%$ & $12,16 \%$ & $13,49 \%$ & $14,01 \%$ & $14,01 \%$ \\
\hline Ruim & $3,79 \%$ & $6,25 \%$ & $0,68 \%$ & $2,30 \%$ & $3,25 \%$ & $3,25 \%$ \\
\hline Pássimo & $1,26 \%$ & $2,68 \%$ & $2,03 \%$ & $0,33 \%$ & $1,58 \%$ & $1,58 \%$ \\
\hline Total & $21,47 \%$ & $20,53 \%$ & $20,94 \%$ & $29,93 \%$ & $23,22 \%$ & $23,22 \%$ \\
\hline
\end{tabular}

Análise da Tabela 47: os entretenimentos foram considerados por 38,92\% dos entrevistados como bom e 19,02\% consideraram ótimos, más 23,22\% não responderam esta questão.

Tabela 48 - Preços

\begin{tabular}{l|c|c|c|c|c|c}
\hline \multicolumn{1}{c|}{ Variáveis } & $\begin{array}{c}\text { Semana } \\
\text { Santa }\end{array}$ & $\begin{array}{c}\text { Final de } \\
\text { Semana } \\
\text { Comum }\end{array}$ & $\begin{array}{c}\text { Festa do } \\
\text { Divino } \\
\text { Cavalhadas }\end{array}$ & $\begin{array}{c}\text { Férias de } \\
\text { Julho }\end{array}$ & $\begin{array}{c}\text { Média } \\
\text { Parcial }\end{array}$ & $\begin{array}{c}\text { Média } \\
\text { Total }\end{array}$ \\
\hline Ótimo & $1,26 \%$ & $4,46 \%$ & $3,38 \%$ & $3,29 \%$ & $3,10 \%$ & $3,10 \%$ \\
\hline Bom & $23,74 \%$ & $30,36 \%$ & $25,00 \%$ & $28,62 \%$ & $26,93 \%$ & $26,93 \%$ \\
\hline Regular & $29,80 \%$ & $33,93 \%$ & $38,51 \%$ & $28,29 \%$ & $32,63 \%$ & $32,63 \%$ \\
\hline Ruim & $18,69 \%$ & $12,50 \%$ & $11,49 \%$ & $10,86 \%$ & $13,39 \%$ & $13,39 \%$ \\
\hline Pássimo & $11,36 \%$ & $10,71 \%$ & $8,78 \%$ & $8,88 \%$ & $9,93 \%$ & $9,93 \%$ \\
\hline Total & $15,15 \%$ & $8,04 \%$ & $12,84 \%$ & $20,06 \%$ & $14,02 \%$ & $14,02 \%$ \\
\hline
\end{tabular}

Análise da Tabela 48: em relação aos preços 32,63\% dos entrevistados consideraram regular, enquanto que $26,93 \%$ consideraram bom e $13,39 \%$ ruim. Podemos concluir, portanto, que os preços não estão agradando muito os visitantes. 


\section{9 - INTERPRETAÇÃO DOS RESULTADOS}

\section{1 - Tendências}

As pesquisas realizadas em anos anteriores (2001 e 2002) buscavam conhecer o perfil, a motivação e a percepção dos visitantes de Pirenópolis em algumas ocasiões também, pré-determinadas. Porém, o questionário utilizado em 2003 apresentou algumas modificações em relação ao de 2002 para atender melhor as necessidades da pesquisa. As variáveis abordadas que sofreram alterações foram as seguintes: idade, agrupamento, grau de instrução e renda pessoal. As variáveis excluídas: estado civil, quais as épocas de visitação, e se atendeu às expectativas.

De acordo com as amostragens, percebe-se que a maioria dos visitantes entrevistados foi do sexo feminino, proveniente do Distrito Federal. No ano de 2002, a faixa etária era entre 22 e 40 anos, com destaque para servidores públicos. Em 2003, a faixa etária foi entre 20 e 29 anos e o destaque foi para funcionários de empresas privadas. Quanto à formação, percebe-se que grande parte dos visitantes possuía curso superior. Em 2002, a maior parte dos entrevistados era pessoas solteiras e já haviam visitado a região.

No que diz respeito às tendências econômicas, os entrevistados no ano de 2003 possuíam uma renda pessoal mais elevada que os do ano anterior, sendo que os visitantes provenientes do Distrito Federal tiveram um gasto mais elevado.

Quanto às características de viagem, a maior parcela dos visitantes hospedou em hotéis/pousadas, com a família, permanecendo de 2 a 4 dias. O meio de transporte mais utilizado foi o carro. No ano de 2002 predominou o deslocamento em grupos de amigos.

Sobre as características motivacionais, a maioria deslocou-se a turismo. Quanto às atividades desenvolvidas na região prevaleceu tomar banho em ambiente natural (rios/cachoeiras/lagos), relaxar e descansar, e fazer caminhadas e o principal fator de indução da viagem foi à indicação de amigos e parentes. 
Referente às características perceptórias, estas foram agrupadas em atrativos, infra-estrutura, equipamentos e serviços turísticos. De acordo com as informações dos visitantes, estas foram consideradas como ótimas, boas, regulares, ruins e péssimas. Nos respectivos feriados, os atrativos foram avaliados como bons. Em relação à infra-estrutura, percebe-se a mesma incidência nos feriados, ressaltando apenas latões de lixo que foram considerados como péssimo, no ano de 2002, e regular no ano de 2003. Já os itens de equipamentos e serviços turísticos, foram avaliados como bons, exceto preços, que foram avaliados como regular e a hospitalidade como ótima.

A maioria dos visitantes entrevistados não tiveram acesso aos guias da região. Em 2003, foi questionada a utilização dos serviços de guias e sua avaliação foi que, a grande parte dos entrevistados que encontrou guia utilizou seus serviços, e destes, boa parcela os avaliou como ótima.

Ps: A pesquisa de 2002 foi publicada pela AGETUR, intitulada: Turismo em Dados Caminho do Ouro. Goiânia, 2002.

Através da análise dos resultados da pesquisa de campo com os visitantes no município de Pirenópolis em quatro ocasiões, as hipóteses levantadas foram confirmadas, pois as respostas aos questionamentos forma consideradas satisfatórias, ou seja, em todos os pontos pesquisados, com a segunda parte do questionário (infra-estrutura, avaliação dos atrativos e avaliação dos equipamentos e serviços turísticos), a soma do percentual de ótimo e bom foi maior.

Más através destas analise observamos que o desempenho da atividade turística, ainda deixa a desejar no tocante a alguns aspectos relevantes a infra-estrutura, atrativos, equipamentos e serviços. Pois, é necessário avaliar o percentual que considerou de regular para péssimo estes serviços turísticos. 


\section{CONSIDERAÇÕES FINAIS}

O objetivo deste projeto é caracterizar e dimensionar o mercado turístico, através de levantamento dos dados relativos ao Visitante (perfil, motivação e percepção) do Município turístico de Pirenópolis no estados de Goiás, utilizando métodos de pesquisa em lócus, para diagnosticar a qualidade da atividade turística desenvolvida neste município.

Foram pesquisados os turistas que visitaram o município na Semana Santa (16 a 21 de abril), em um final de semana comum (16 a 18 de maio), na festa do Divino Cavalhadas (08 a 09 de junho) e nas férias de julho (11 a 17 de julho). As pesquisas foram realizadas em épocas distintas, pois para uma análise mais detalhada é imprescindível captar informações na alta e na baixa temporada, tornando o estudo mais abrangente e rico de informações relevantes.

Identificamos o perfil, a motivação e a percepção dos visitantes do município e constatamos que são variados perfis, inúmeras motivações e singulares percepções do espaço e dos serviços. Foram utilizados métodos de pesquisa para o levantamento dos dados, e servirão para alavancar e estimular o mercado turístico, auxiliando em seu desenvolvimento.

Após análise dos dados, constatamos que o município de Pirenópolis tem conseguido prestar serviços turísticos de qualidade aos seus visitantes, as respostas que avaliam as variáveis (Informações; Hospitalidade; Atendimento e Preços) foram positivas, visto que, o percentual de respostas que consideraram os serviços regulares é inferior as alternativas: bom e ótimo. E, também, possui equipamentos para o desempenho da atividade turística, devido as variáveis (Hospedagem, Alimentação e Entretenimento) serem classificadas como boas.

Os atrativos turísticos são aprazíveis, pois a análise das perguntas que contemplam tal questão (Acesso aos atrativos; Sinalização até os atrativos; Sinalização dentro dos atrativos; 
Limpeza; Patrimônio histórico; Matas; Rios/cachoeiras/lagos; Monumentos; Cavernas/grutas/serras/morros; Segurança nos atrativos) os avaliaram como bom.

A infra-estrutura é adequada para o desenvolvimento do turismo, pois segundo as variáveis perguntadas (Acesso ao município; Sinalização nas rodovias; Sinalização dentro do município; Aparência da cidade; Limpeza urbana; latões de lixo; Iluminação pública; serviço de telefonia; serviço de transporte de uso público; Segurança e Serviços médicos/hospitalares), tais serviços foram considerados adequados.

Em relação ao perfil e a motivação do visitante, constatamos que a origem da maioria dos visitantes é do Distrito Federal, seguido de visitantes da cidade de Goiânia, isso devido à proximidade das duas localidades com o município. Os visitantes eram em sua maioria, do sexo feminino, mas esta incidência foi de apenas $2,14 \%$ sobre o sexo masculino. Possui cursos superiores e empregos privados, com uma renda pessoal superior a mil reais mensais. A idade aproximada destes visitantes variou entre 20 a 29 anos, caracterizamos, portanto, como público jovem. O gasto médio por dia é de aproximadamente $\mathrm{R} \$ 68,22$ e o tempo de permanência varia entre dois a quatro dias.

Estes visitantes viajam com a família e com os amigos, o meio de transporte mais utilizado é o carro, isso porque, o carro ainda é o meio de locomoção mais barato e o município ainda não possui aeroporto, sendo o mais próximo na cidade de Brasília ou Goiânia. Hospedam-se em hotéis e pousadas, haja vista, que o município possui uma quantidade boa de leitos e muitos possuem qualidade, más existem hospedagens para todos os níveis econômicos.

O motivo que leva os visitantes a procurarem o município é o turismo, isso porque, é classificado como turístico e conseqüentemente, possui atrativos de varias espécies. As atividades mais praticadas são de relaxamento e descanso; visitação as cachoeiras e rios; caminhada e a contemplação da natureza, que na região é bem convidativa. A divulgação do lugar é realizada através de parentes e amigos, o famoso "boca a boca". A maioria já havia visitado a região em outras ocasiões e pretendem voltar. 
Constatamos ainda, o quanto o Município de Pirenópolis tem potencial e presta serviço de qualidade para o turista. Pois, confirmamos através da motivação destes em escolher a localidade para seu laser, e da percepção com relação à infra-estrutura, equipamentos e serviços turísticos, visto que, as respostas variam, em sua maioria, entre bom e ótimo.

Após, a confirmação das hipóteses, podemos afirmar que a pesquisa turística é fundamental para os municípios classificados como turísticos e também, para aqueles com potencial e que ainda não são, pois poderá ajudar no desenvolvimento ordenado da atividade. É através da pesquisa que se pode constatar suposições e realizar estudos de viabilidade. Quando realizada com seriedade e comprometimento, os dados coletados são fontes de informações valiosíssimas, que conseqüentemente, auxiliarão no crescimento turístico da localidade em questão.

Este trabalho, portanto, vem confirmar a importância da pesquisa para o Município de Pirenópolis, através da analise quantitativa (gráficos e tabelas) e qualitativa dos dados coletados, podemos perceber o quão enriquecedor é a prática da pesquisa para o município e para o pesquisador.

Este projeto, também, tem a intenção de demonstrar a importância da pesquisa turística e como os dados coletados podem contribuir, tanto para a localidade, como para o pesquisador, que no caso específico, foram estudantes dos cursos superiores de turismo da cidade de Goiânia. A troca é rica e os estudantes tiveram a oportunidade de colocar em prática os ensinamentos aprendidos em sala de aula.

Em principio, este projeto nos pareceu inviável devido a sua amplitude no recolhimento de variadas informações, más ao longo dos encontros com o grupo de trabalho (GT) e as pesquisas sobre o assunto, percebemos a sua magnitude e assim, abraçamos esta idéia. Foram dias de estudo e pesquisa, por caminhos, muitas vezes, desconhecidos, más quando percorridos, nos revelaram crescimento e aprendizado sobre o turismo e suas variadas dimensões. 
Esperamos, no entanto, que este projeto de pesquisa possa motivar futuros pesquisadores na busca do conhecimento e na realização de novos estudos, pois a área pesquisada é carente de informações e necessita de crescimento científico. 
ANEXOS

Anexos A:

Gráficos - $\underline{\text { Semana Santa }}$

Gráficos - Final de Semana Comum

Gráficos - Festa do Divino (Cavalhadas)

Gráficos - Férias de Julho

Obs. Os gráficos foram cedidos pela AGETUR 


\section{Semana Santa - Perfil do Visitante}

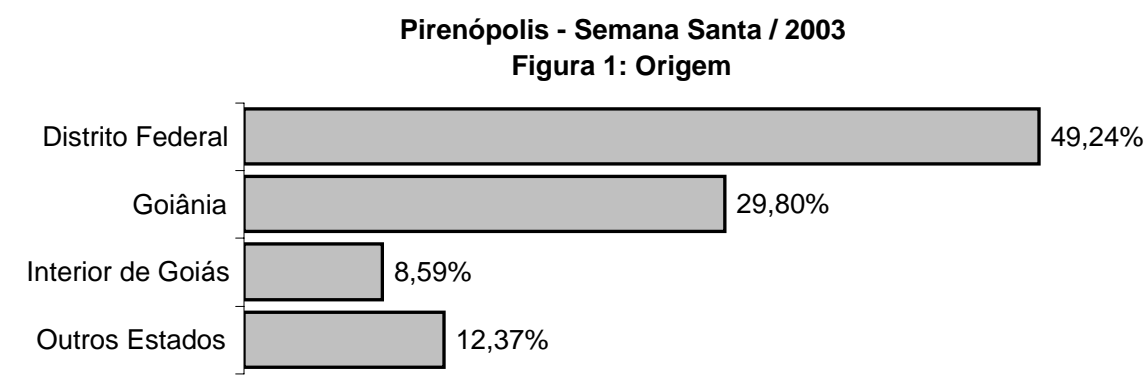

(quesionários respondidos $=397$ )

Pirenópolis - Semana Santa / 2003

Figura 2: Sexo

Feminino

$47,86 \%$

Masculino

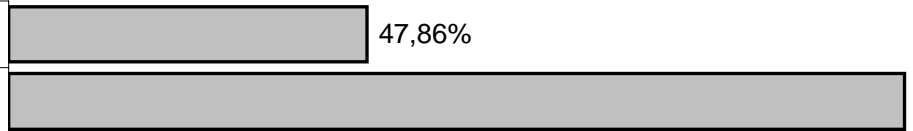

$52,14 \%$

(quesionários respondidos $=397$ )

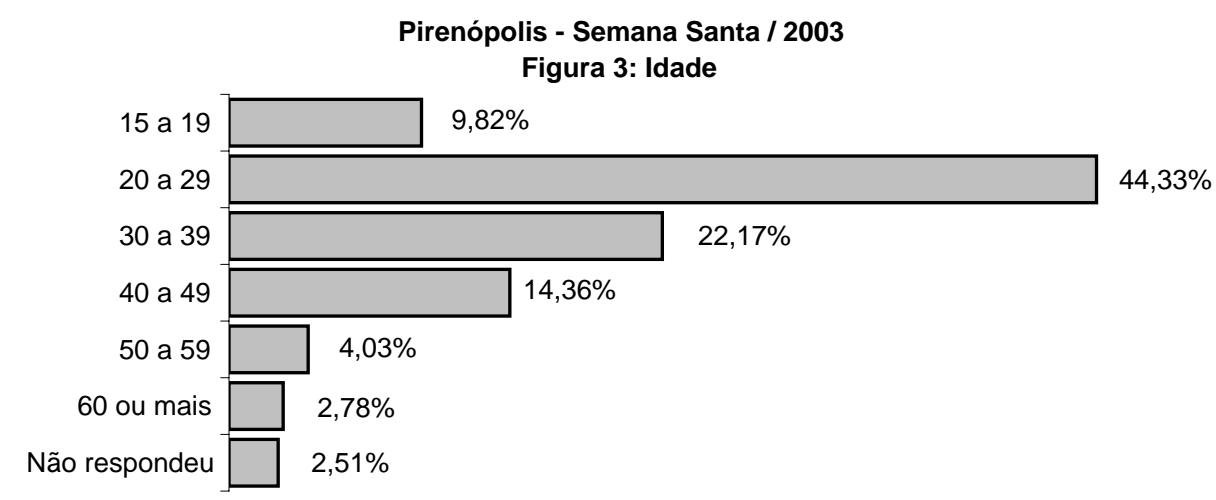

(quesionários respondidos $=\mathbf{3 8 7}$ )

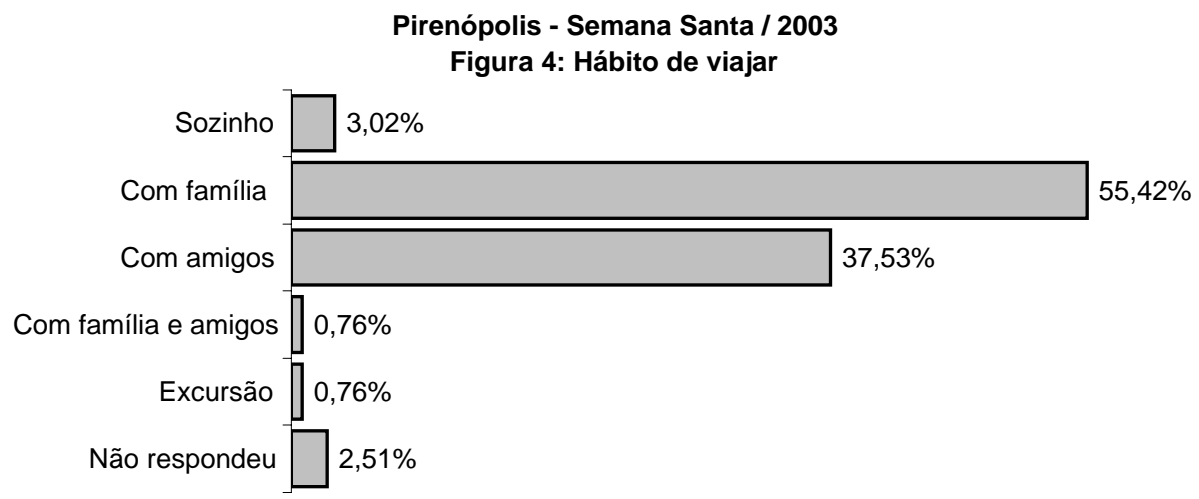

(quesionários respondidos $=387$ ) 


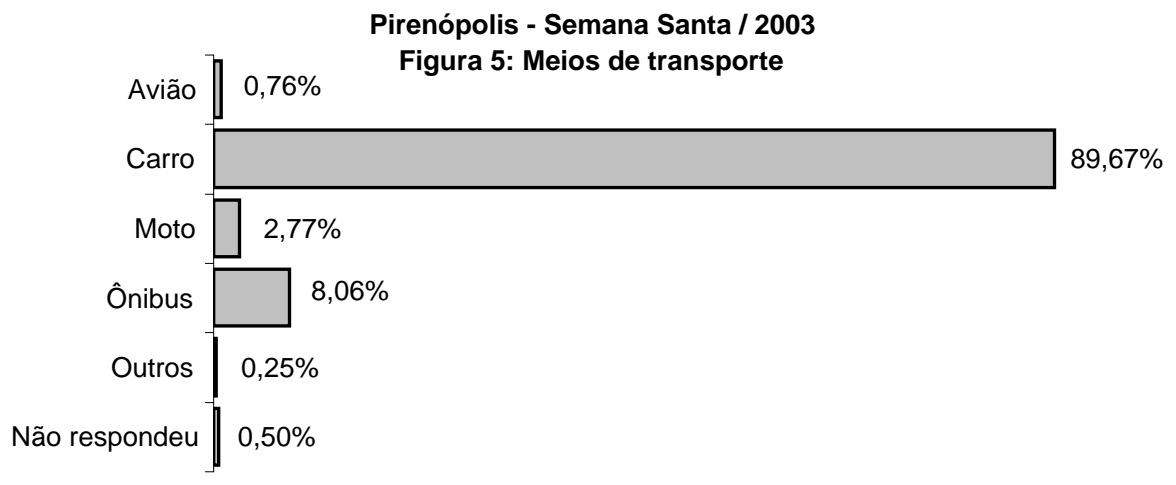

(quesionários respondidos $=395$ )

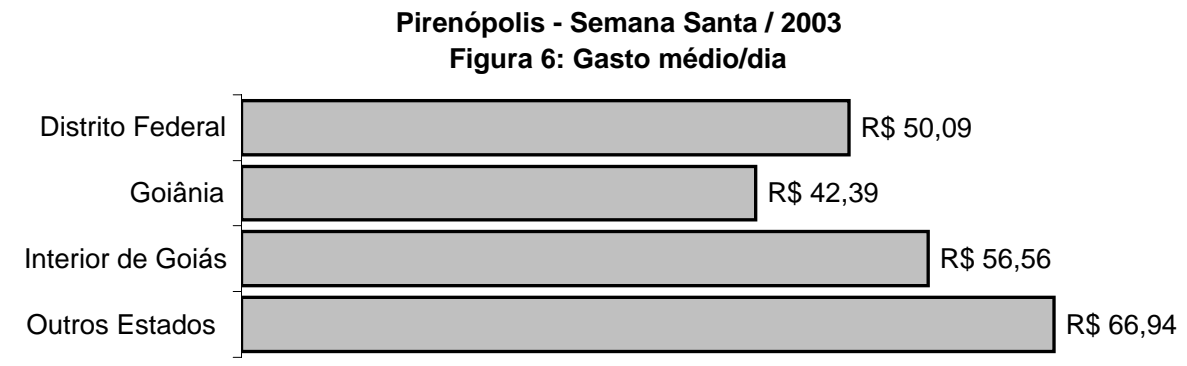

(quesionários respondidos $\mathbf{3} \mathbf{3 7 5}$ )

Pirenópolis - Semana santa / 2003

Figura 7: Local de hospedagem

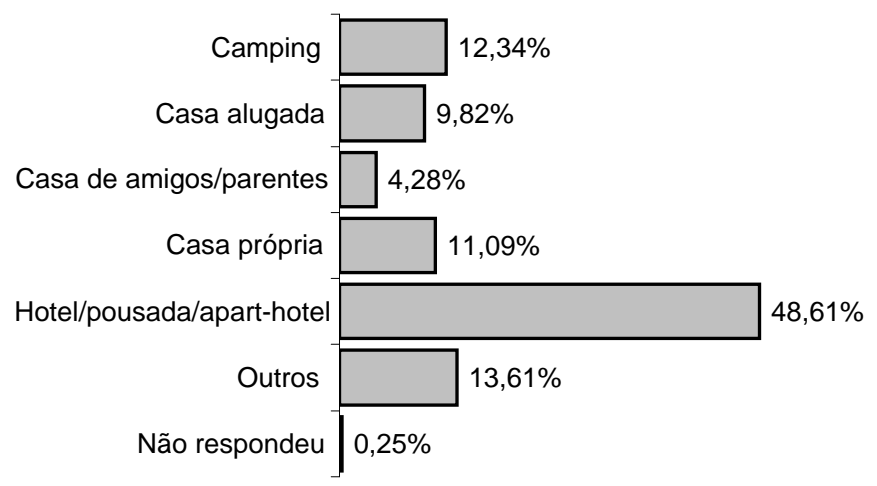

(quesionários respondidos $=396$ )

Pirenópolis - Semana Santa / 2003

Figura 8: Motivo da viagem

\begin{tabular}{|c|c|c|}
\hline Negócios & $2,02 \%$ & \\
\hline Turismo & & $94,71 \%$ \\
\hline Visitar familiares/amigos & $1,76 \%$ & \\
\hline Outros & $1,01 \%$ & \\
\hline Não respondeu & $1,51 \%$ & \\
\hline
\end{tabular}

Obs.: Esta questão permitia ao entrevistado marcar mais de uma resposta. 


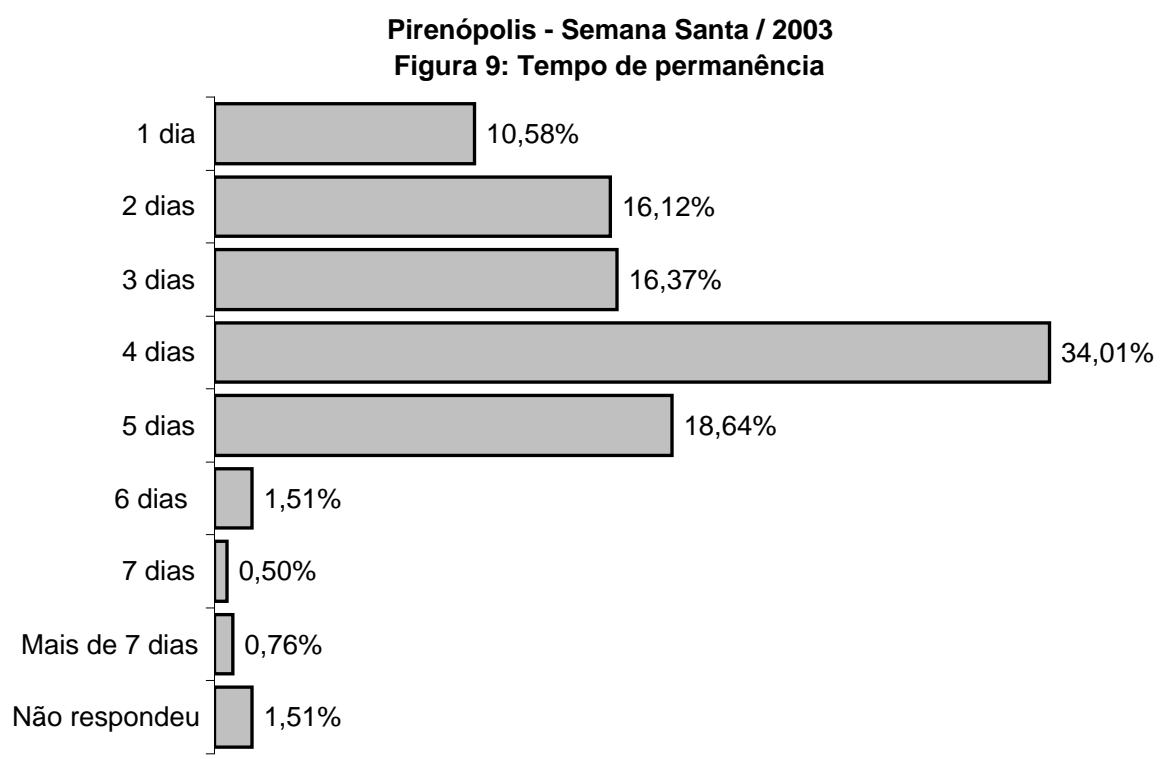

(quesionários respondidos $\mathbf{=}$ 388)

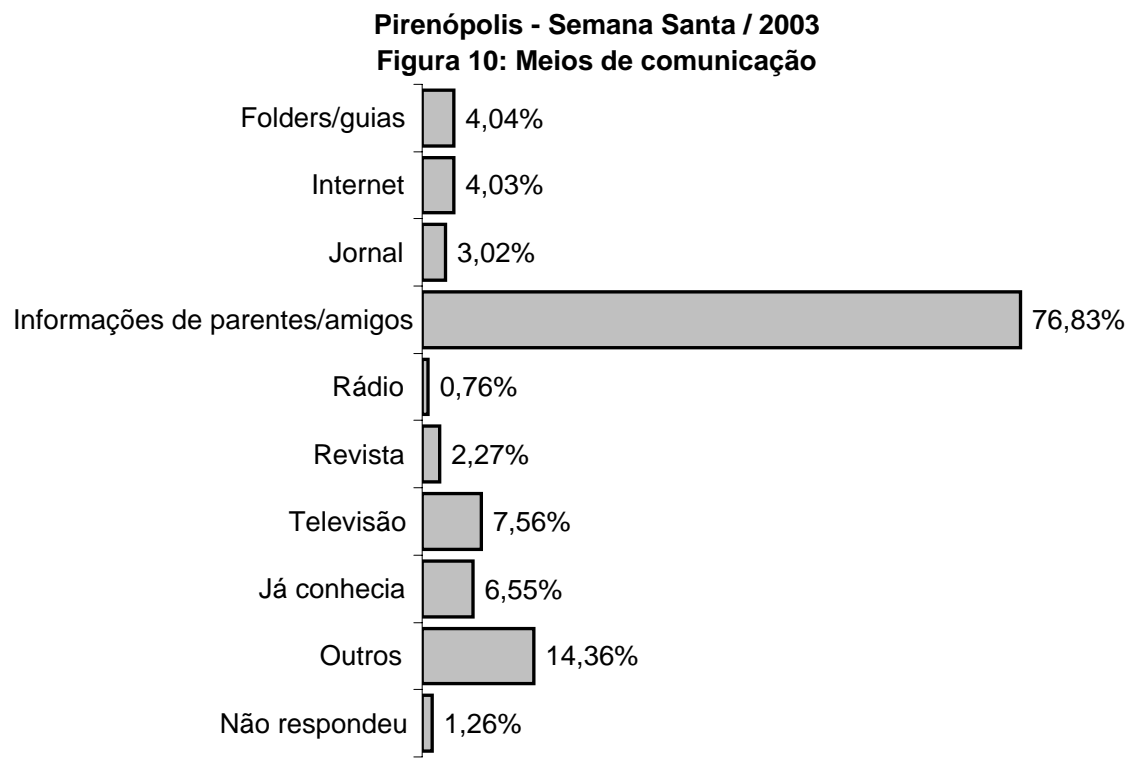

(quesionários respondidos $\mathbf{3}$ 389)

Obs.: Esta questão permitia ao entrevistado marcar mais de uma resposta.

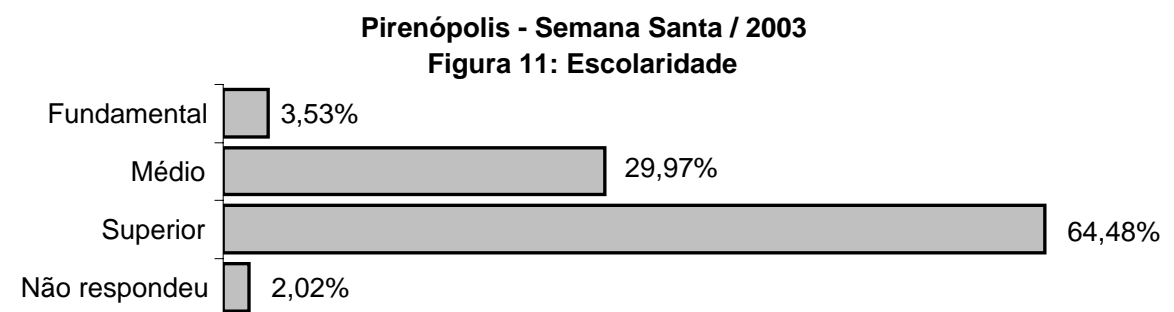

(quesionários respondidos = 389) 


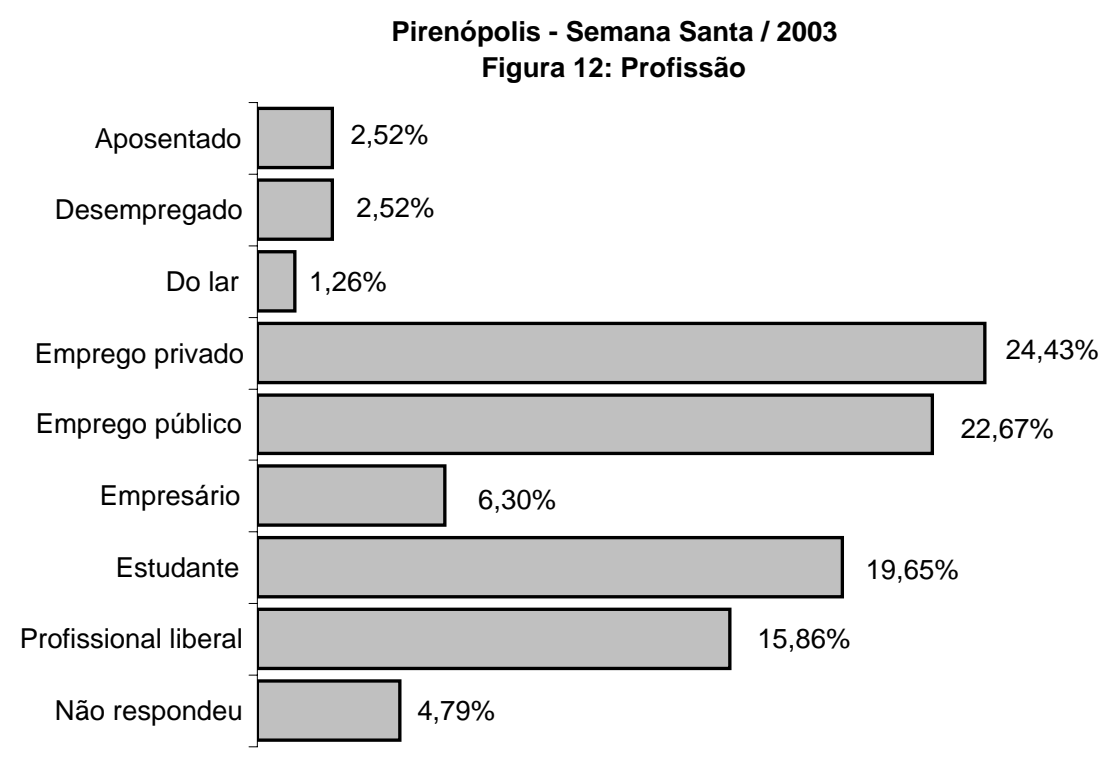

(quesionários respondidos $=\mathbf{3 7 8}$ )

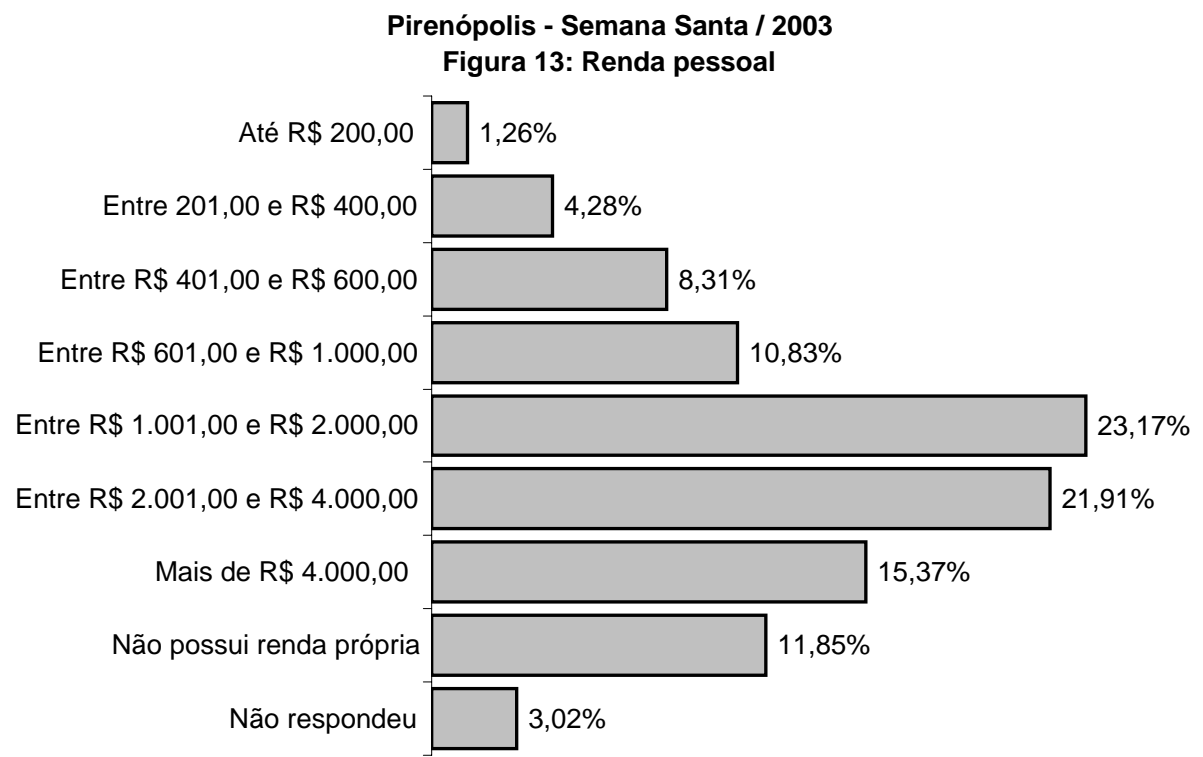

(quesionários respondidos $\mathbf{=} 385$ ) 


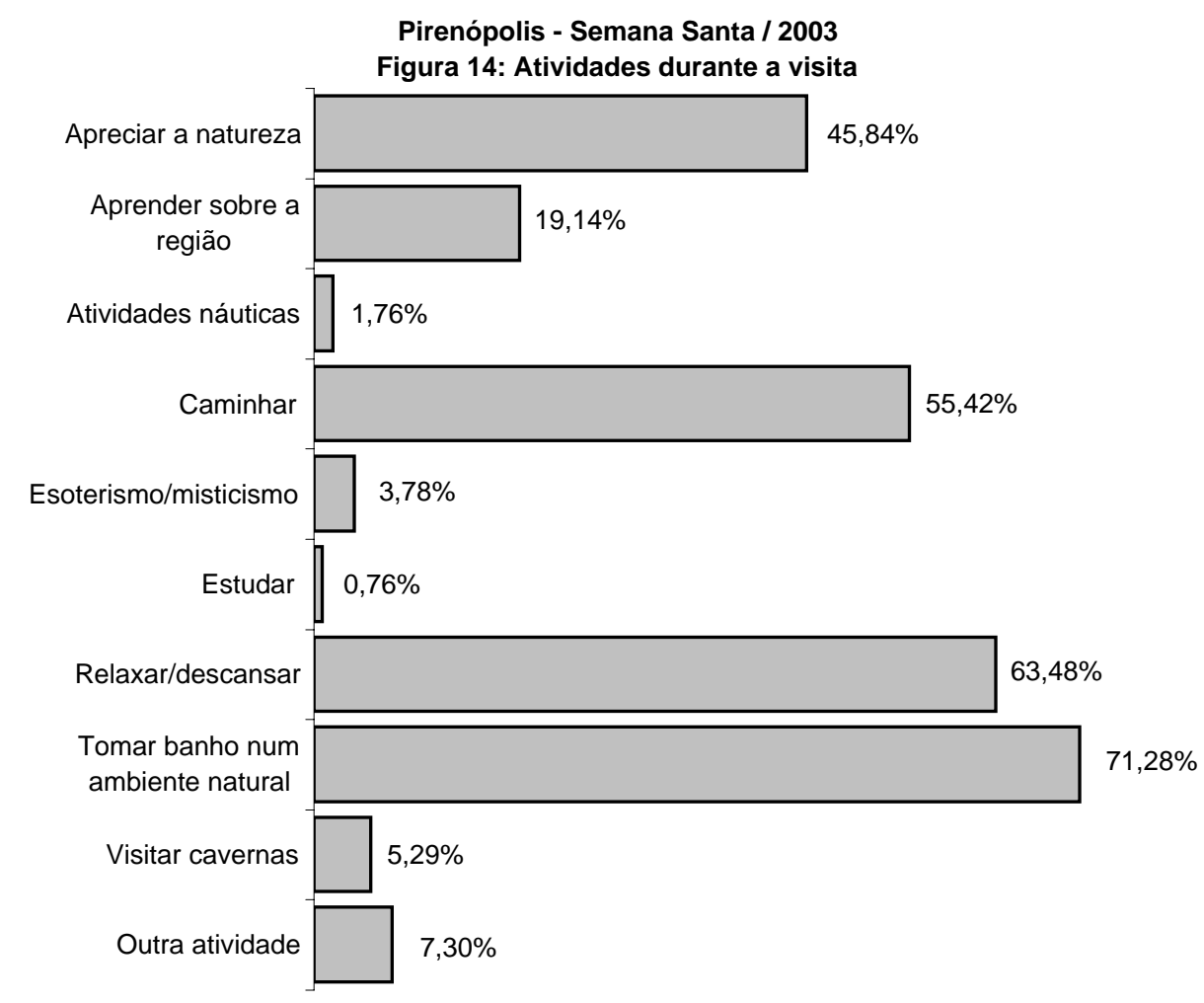

(quesionários respondidos $\mathbf{=} 391$ )

Obs.: Esta questão permitia ao entrevistado marcar mais de uma resposta.

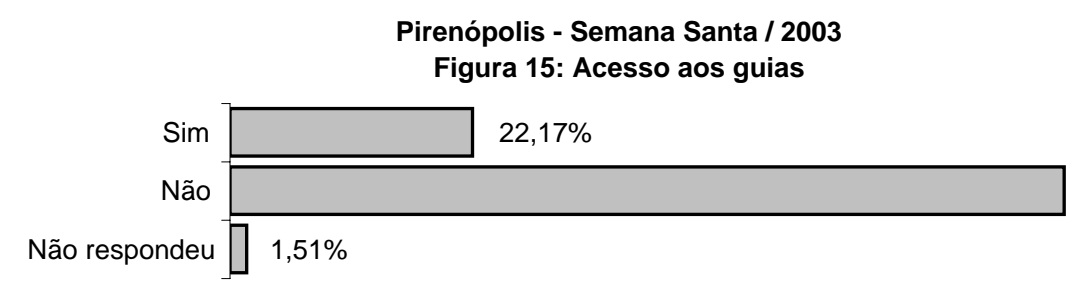

$76,32 \%$

(quesionários respondidos $=\mathbf{3 9 1}$ )

Pirenópolis - Semana Santa / 2003

Figura 16: Utilizou serviços dos guia

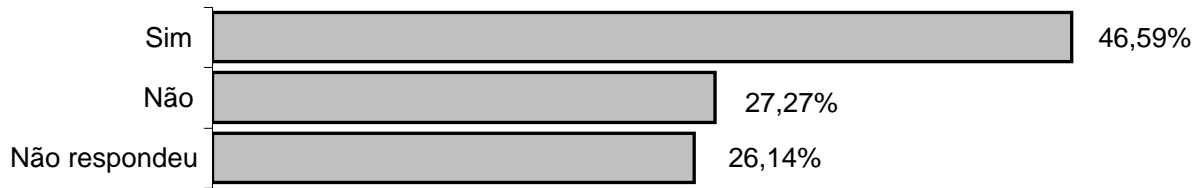

(quesionários respondidos $\mathbf{2}$ 293)

Obs. : Este gráfico refere-se às respostas afirmativas do gráfico anterior. 


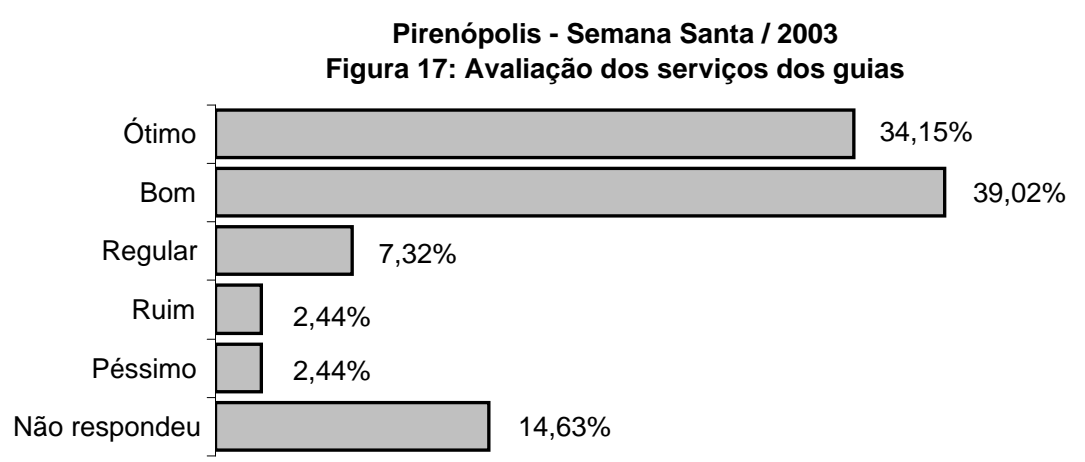

(quesionários respondidos $\mathbf{3 4 0}$ )

Obs. : Esse gráfico refere-se às respostas afirmativas do gráfico anterior.

\section{PERCEPÇÃO DO VISITANTE}

\section{AVALIAÇÃO DA INFRA-ESTRUTURA}

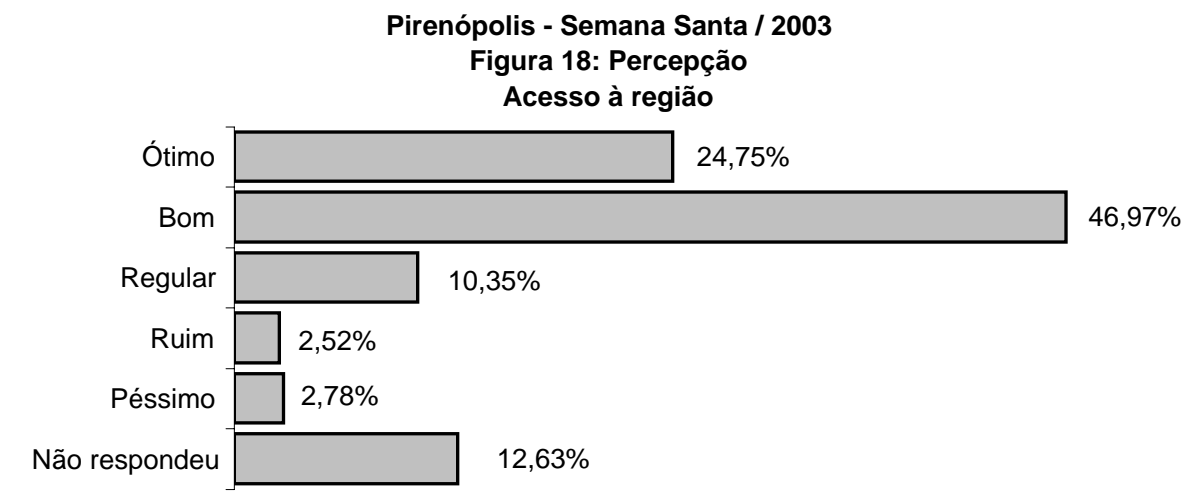

(quesionários respondidos $=347$ )

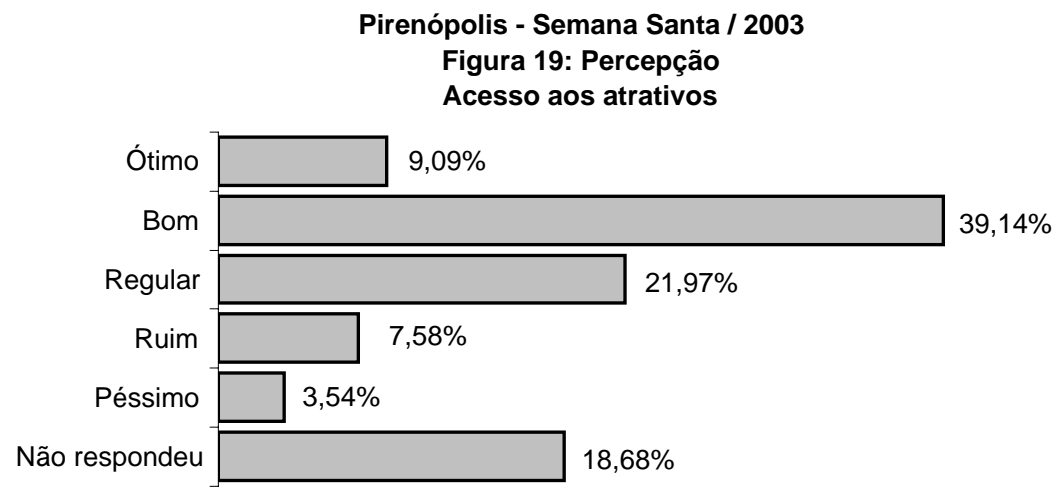

(quesionários respondidos $=323$ ) 


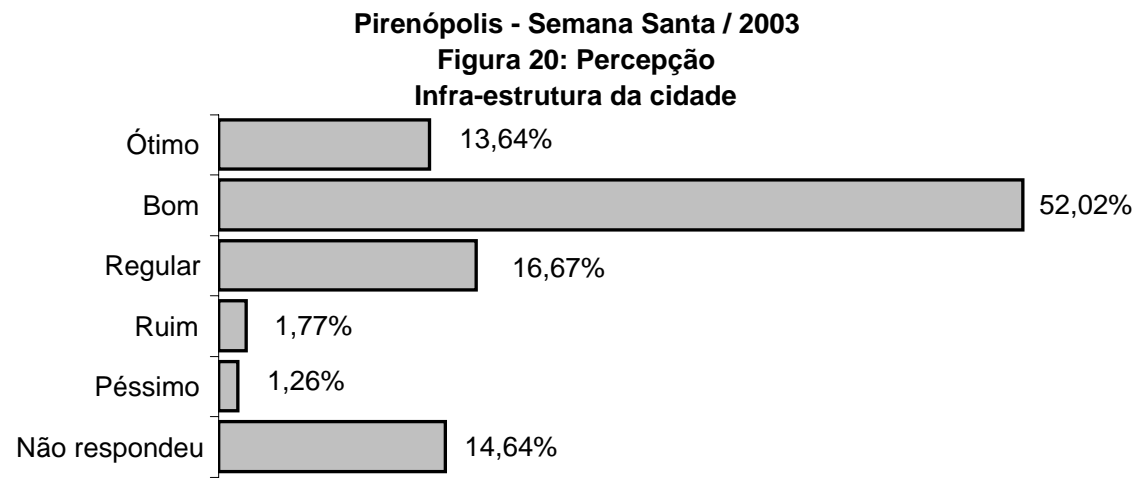

(quesionários respondidos = 339)

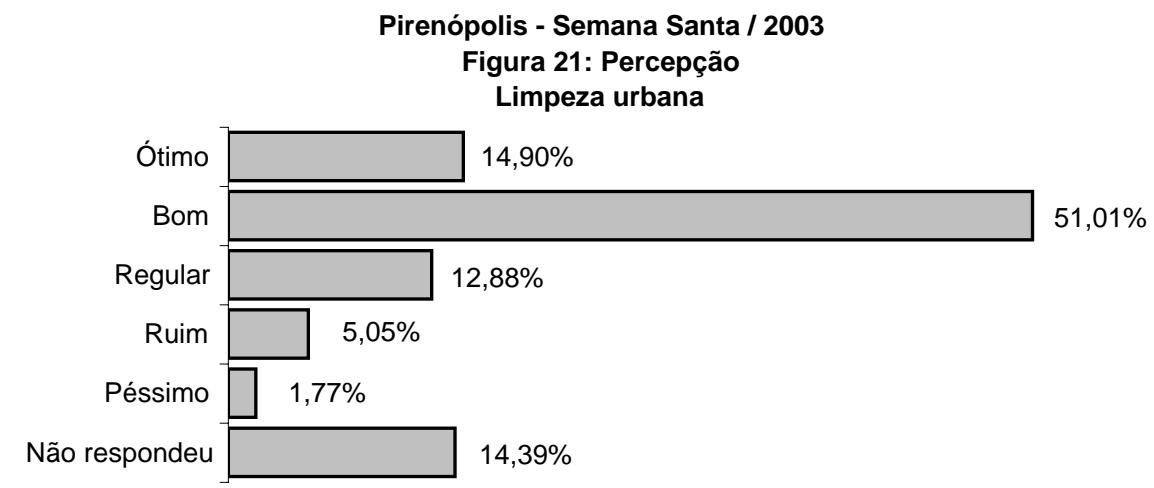

(quesionários respondidos $=\mathbf{3 4 0}$ )

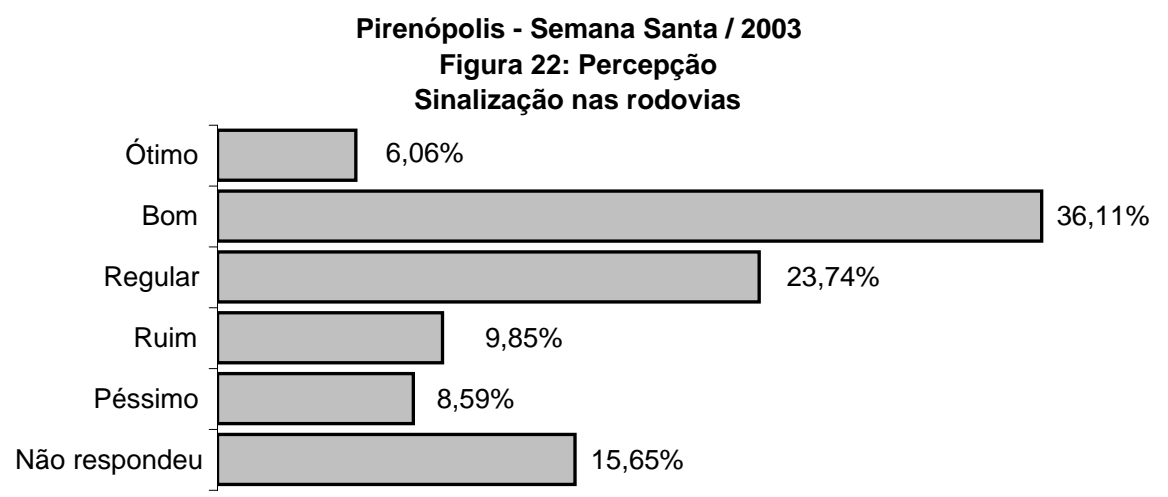

(quesionários respondidos = 335) 


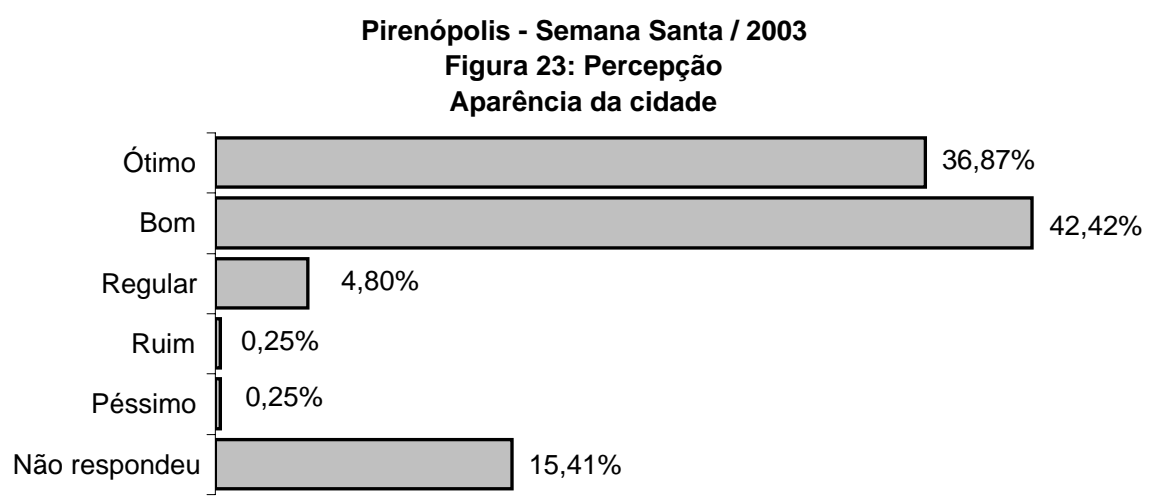

(quesionários respondidos = 336)

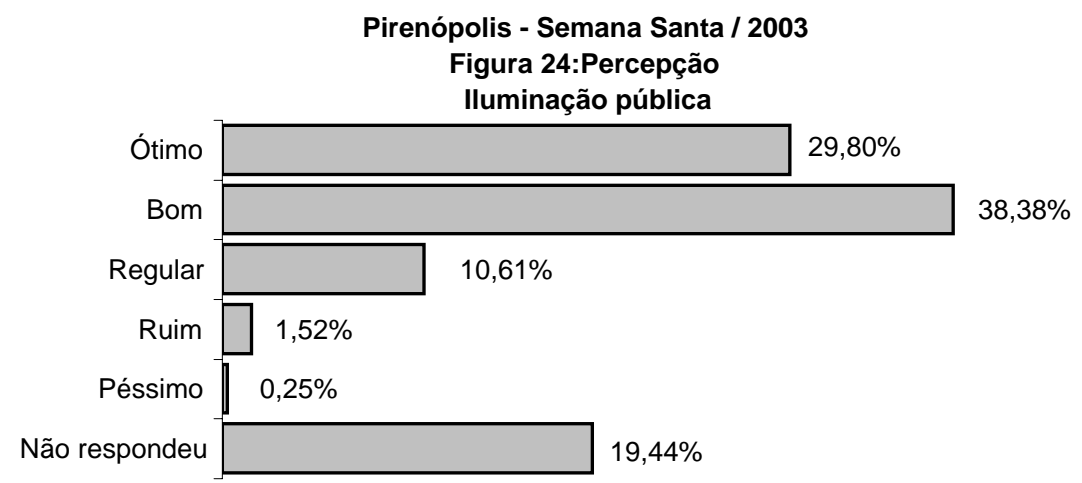

(quesionários respondidos $=\mathbf{3 2 0}$ )

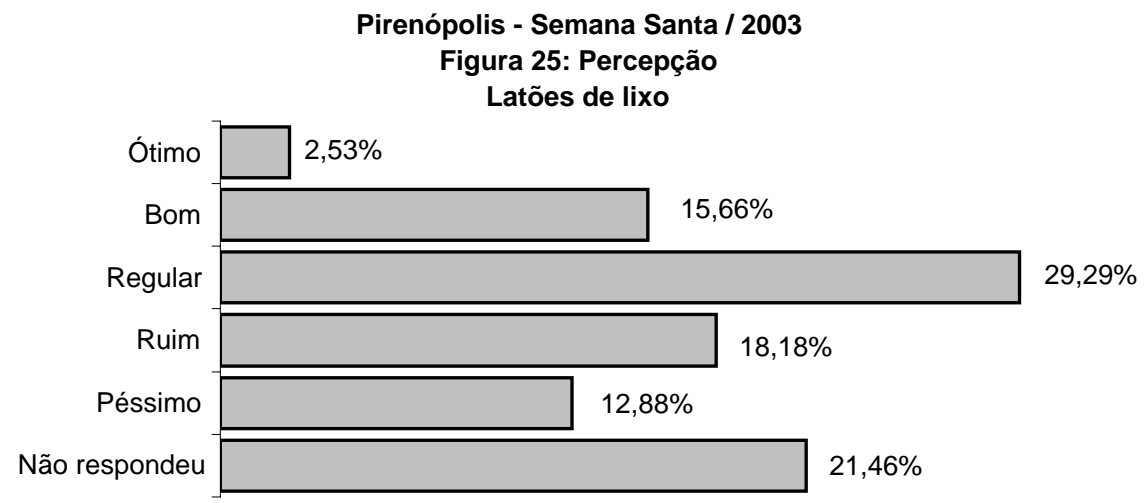

(quesionários respondidos = 312) 


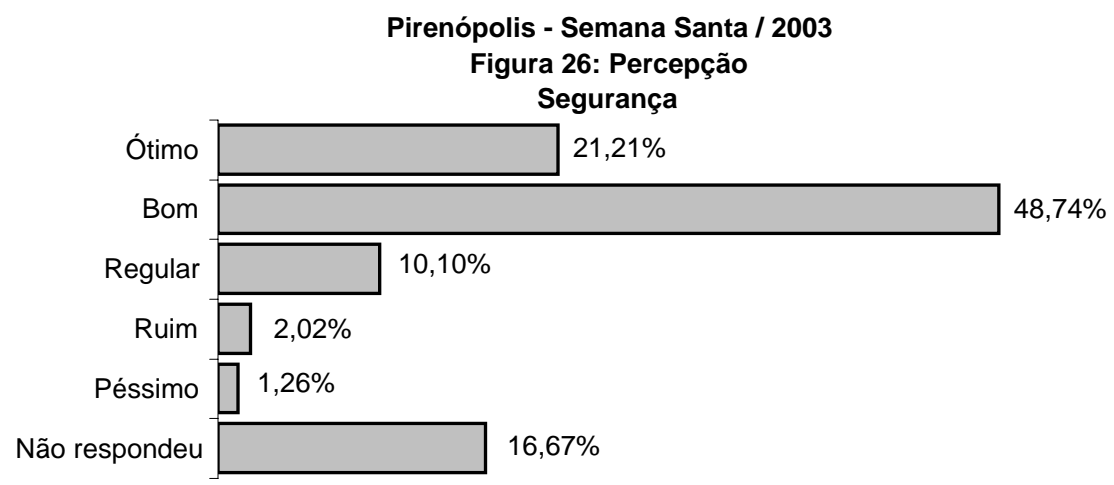

(quesionários respondidos = 331)

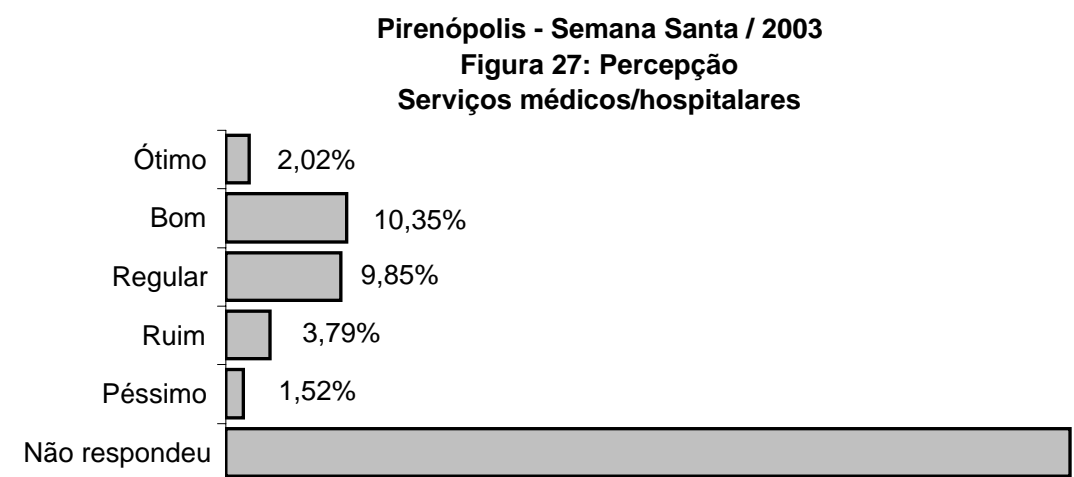

$72,47 \%$

(quesionários respondidos $=109$ )

\section{AVALIACÃO DOS ATRATIVOS}

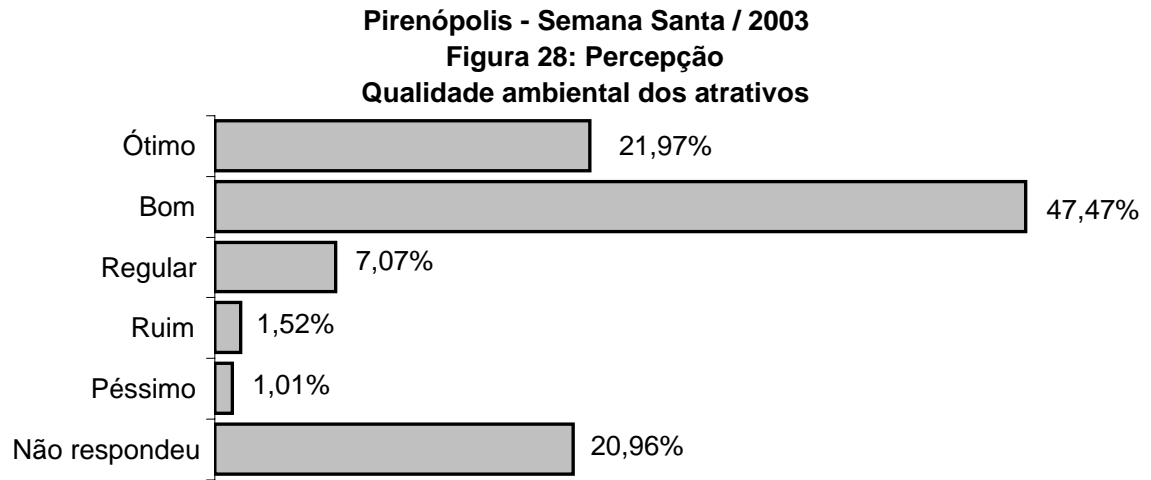

(quesionários respondidos $=314$ ) 


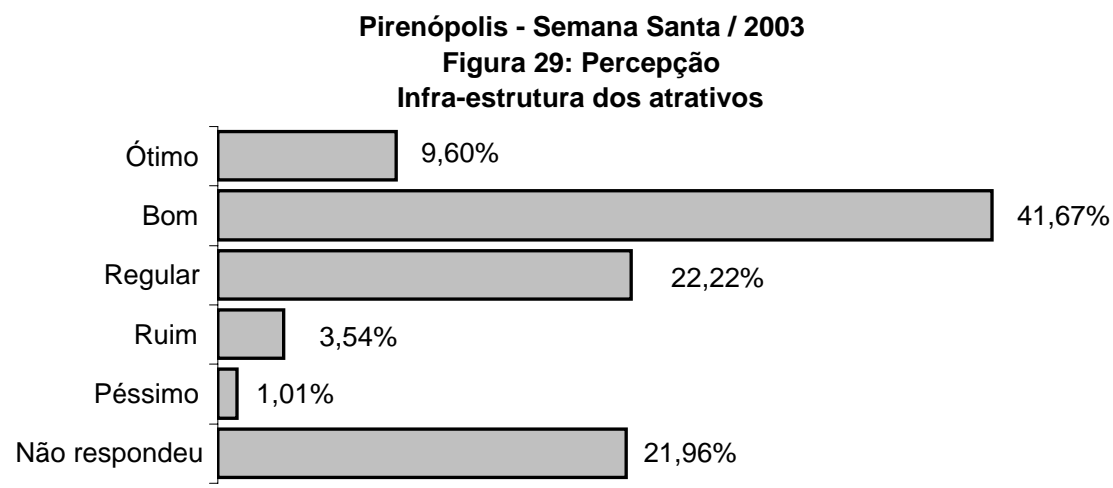

(quesionários respondidos $=313$ )

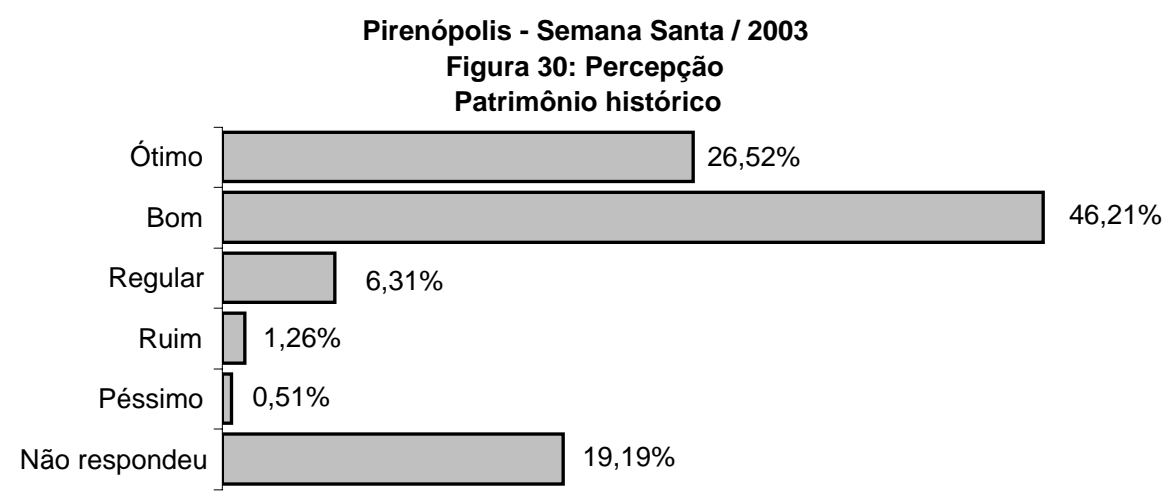

(quesionários respondidos $=321$ )

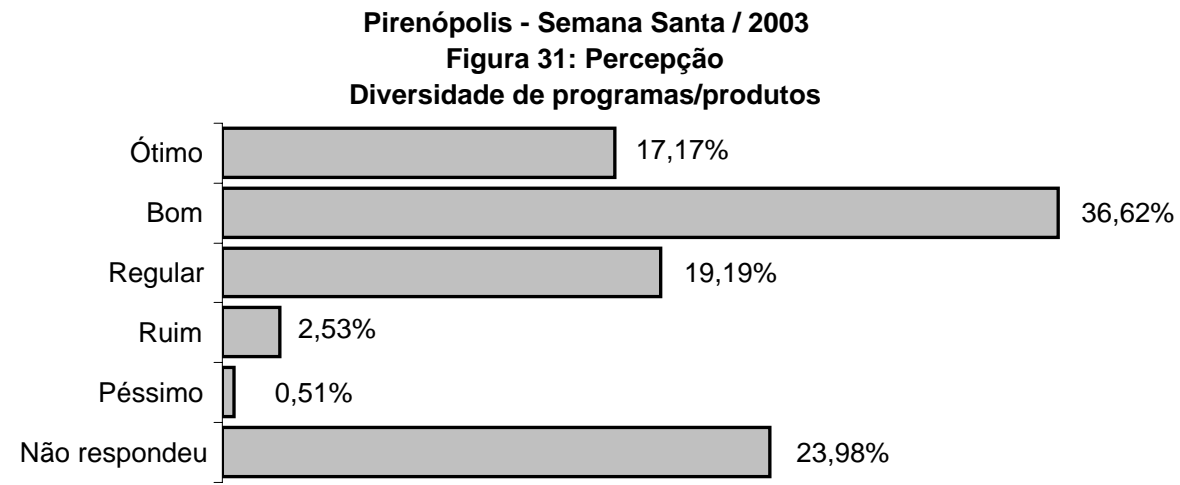

(quesionários respondidos $=\mathbf{3 0 2}$ ) 


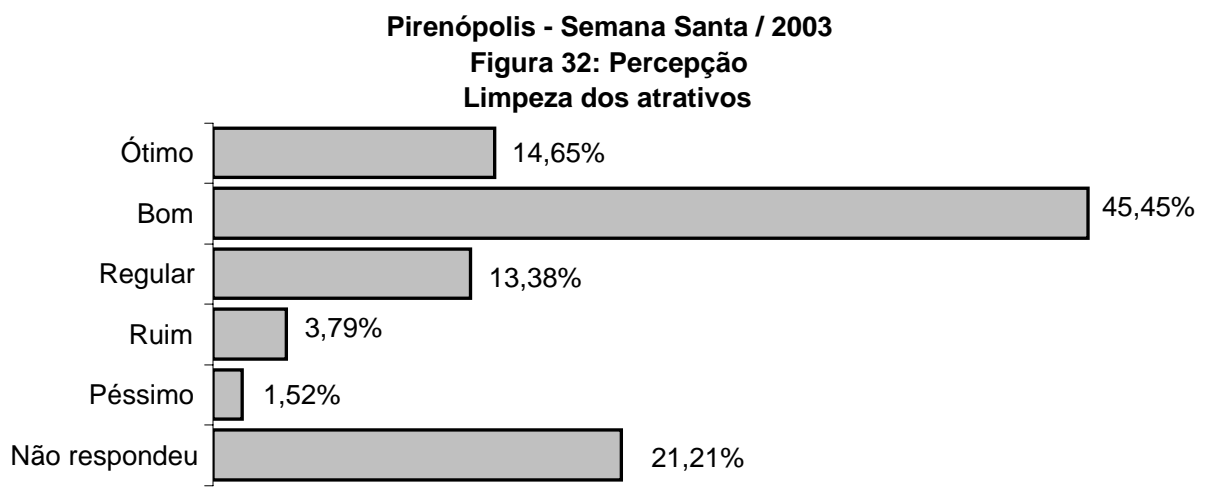

(quesionários respondidos $=313$ )

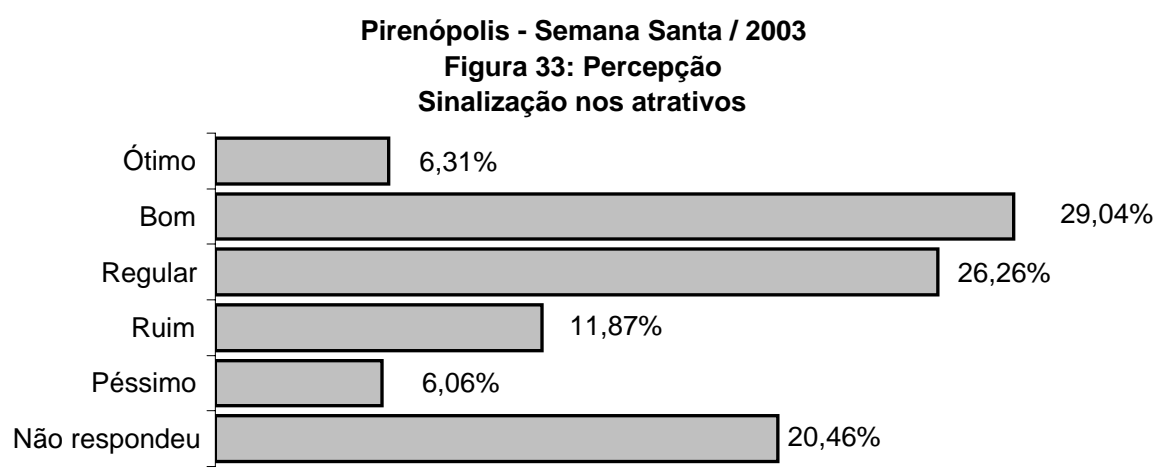

(quesionários respondidos $=316$ )

\section{AVALIAÇÃO DOS EQUIPAMENTOS E SERVIÇOS TURÍSTICOS}

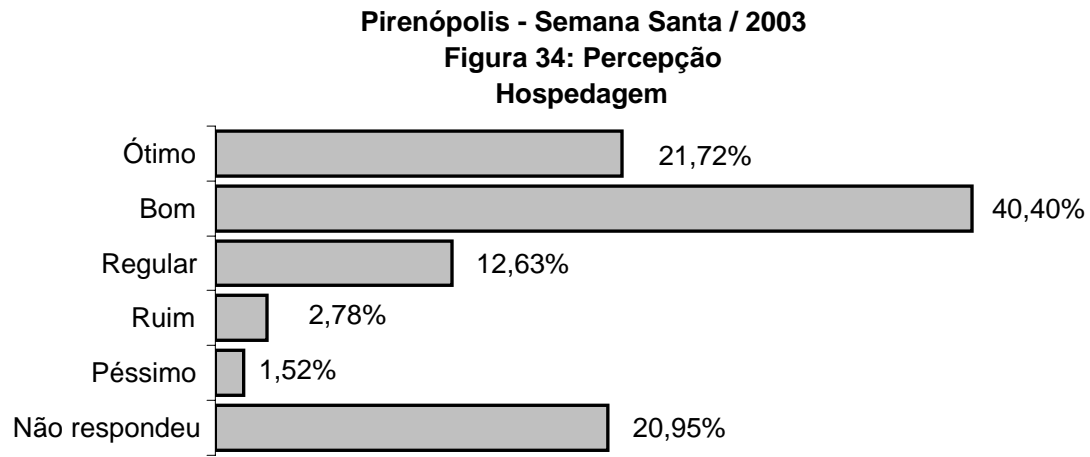

(quesionários respondidos $=314$ ) 


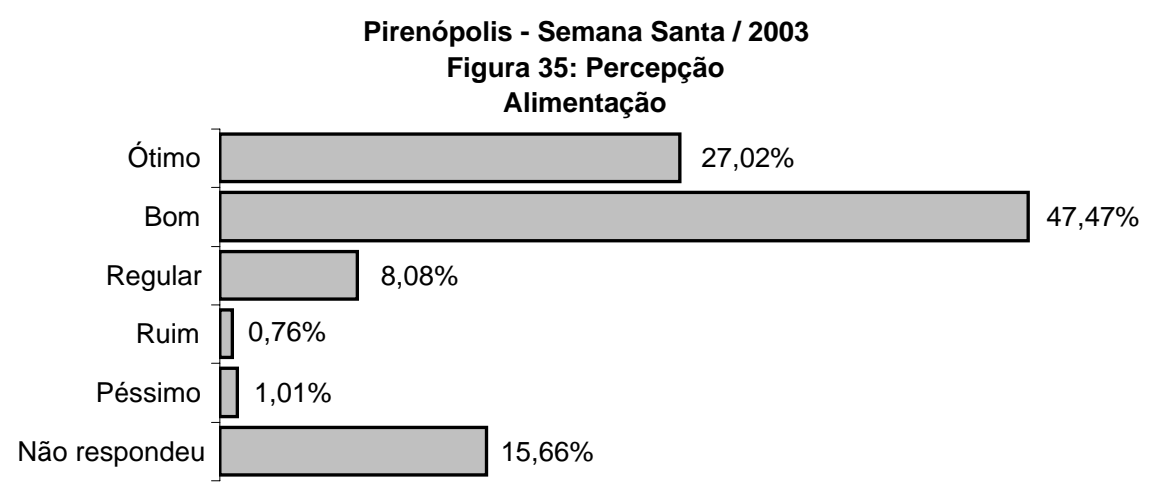

(quesionários respondidos $=335$ )

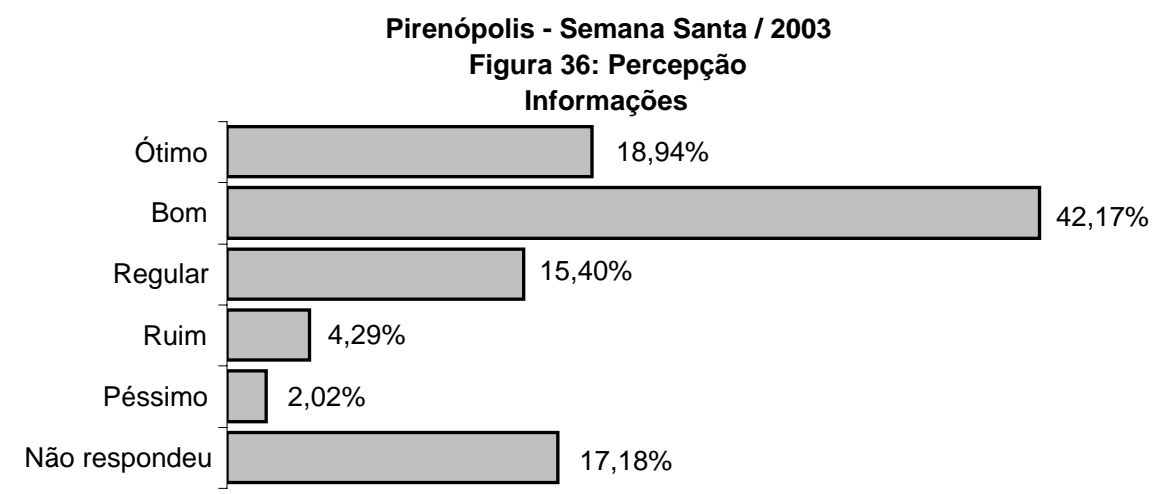

(quesionários respondidos = 329)

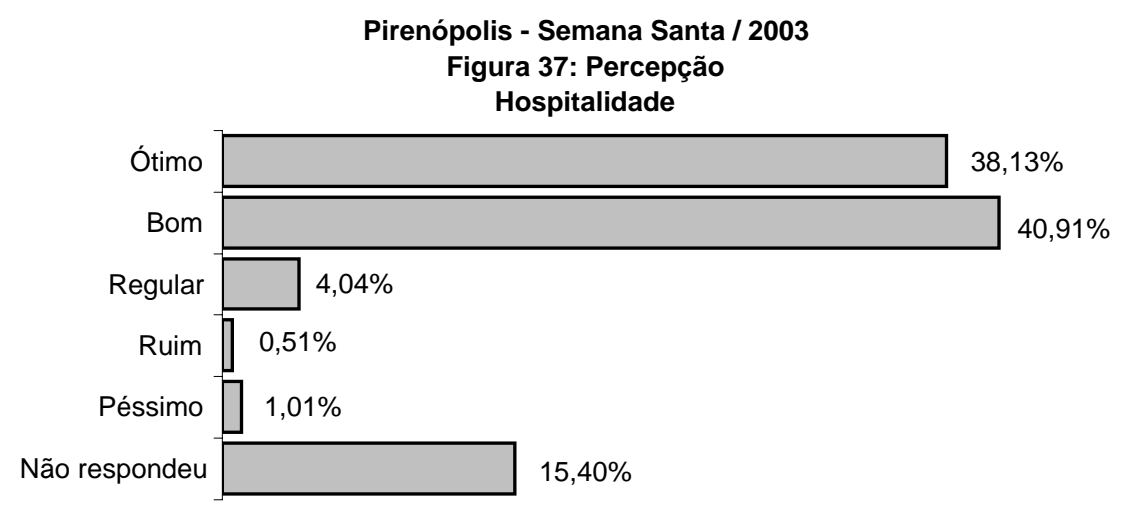

(quesionários respondidos $=336$ ) 


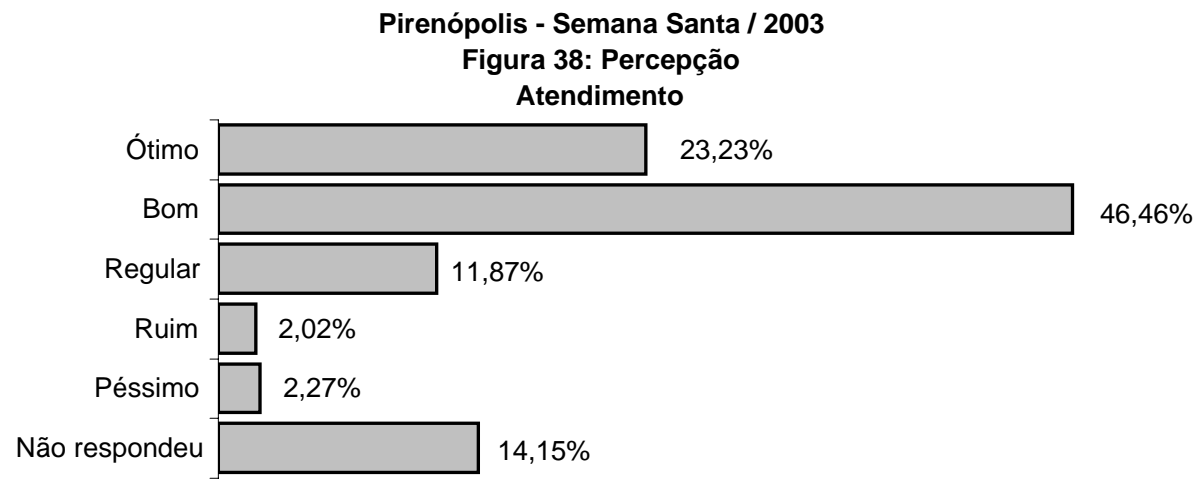

(quesionários respondidos = 341)

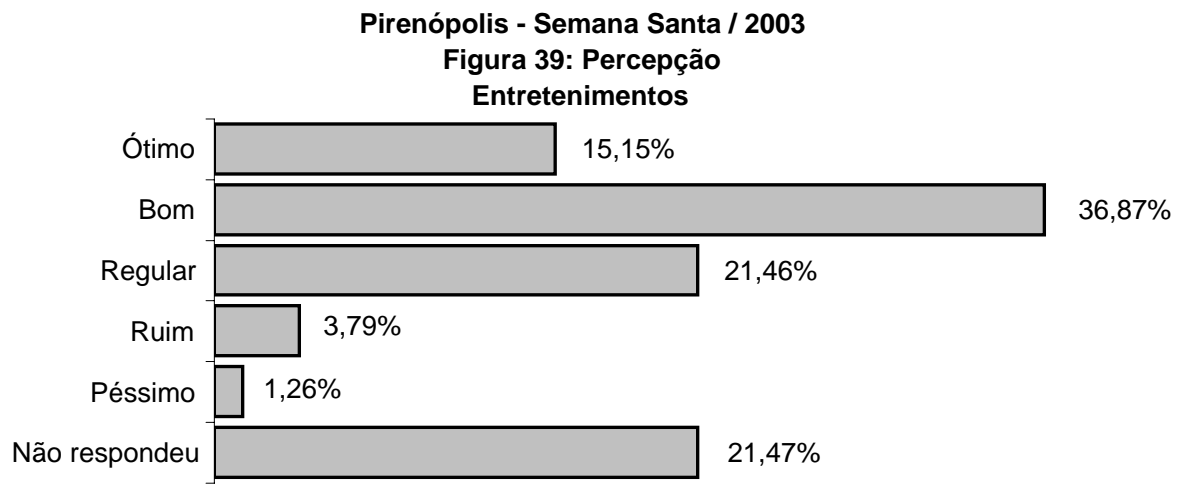

(quesionários respondidos $=312$ )

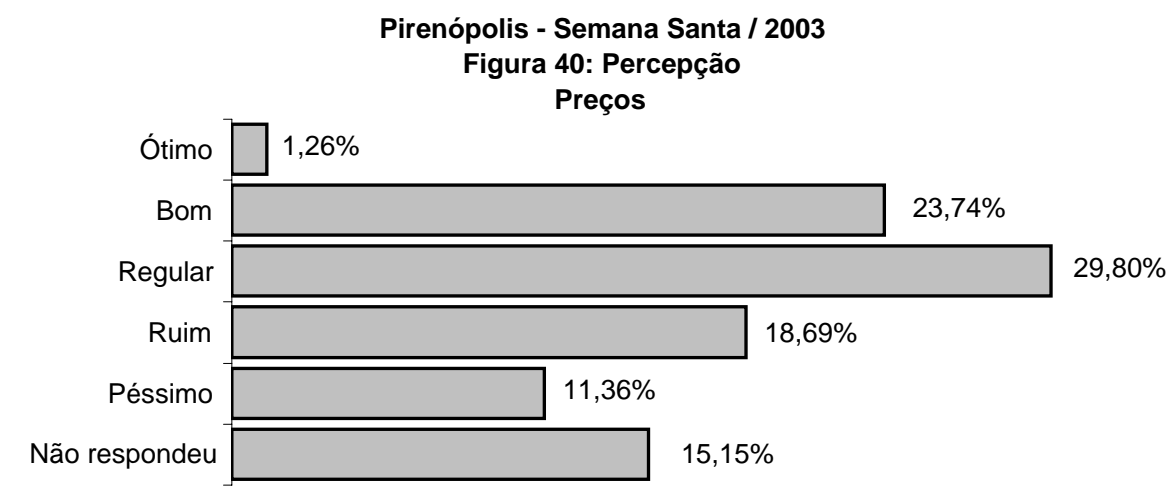

(quesionários respondidos $=337$ ) 


\section{Festa do Divino (Cavalhadas) - Perfil do Visitante}

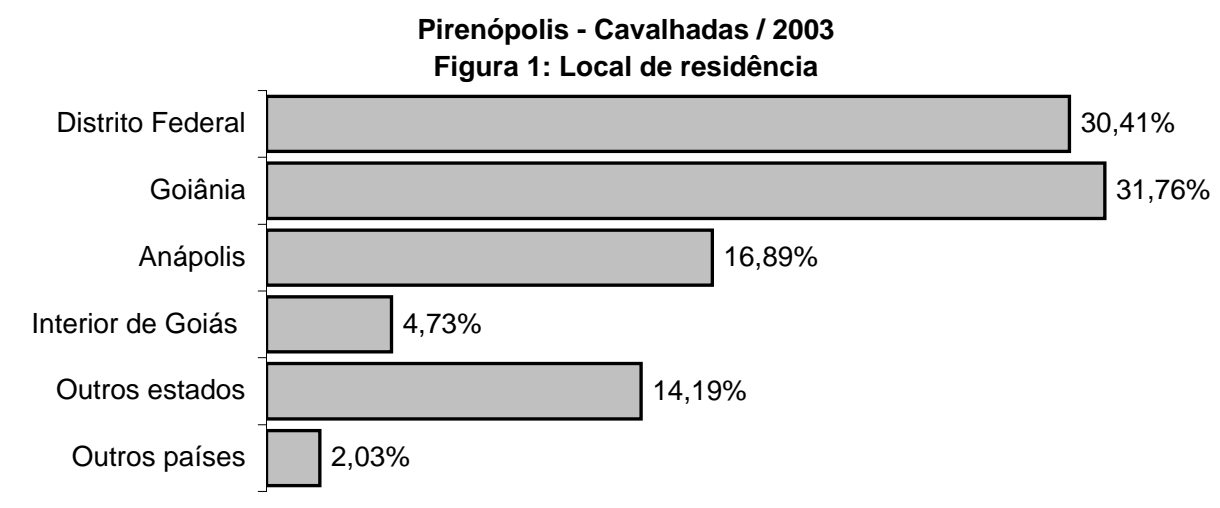

(questionários respondidos $=148$ )

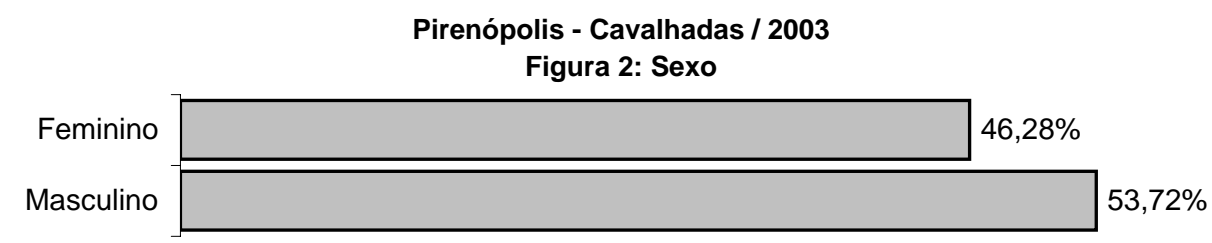

(questionários respondidos $=148$ )

Pirenópolis - Cavalhadas / 2003

Figura 3: Idade

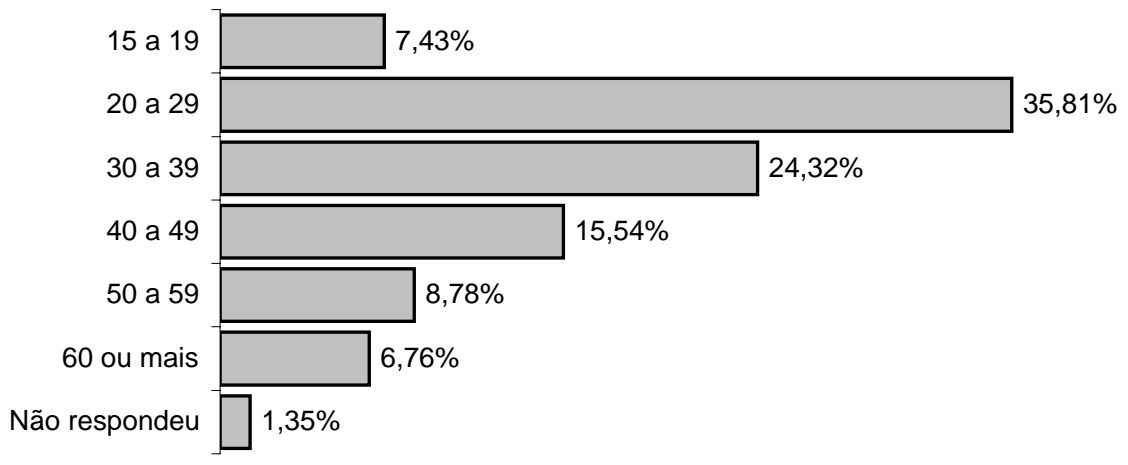

(questionários respondidos = 146)

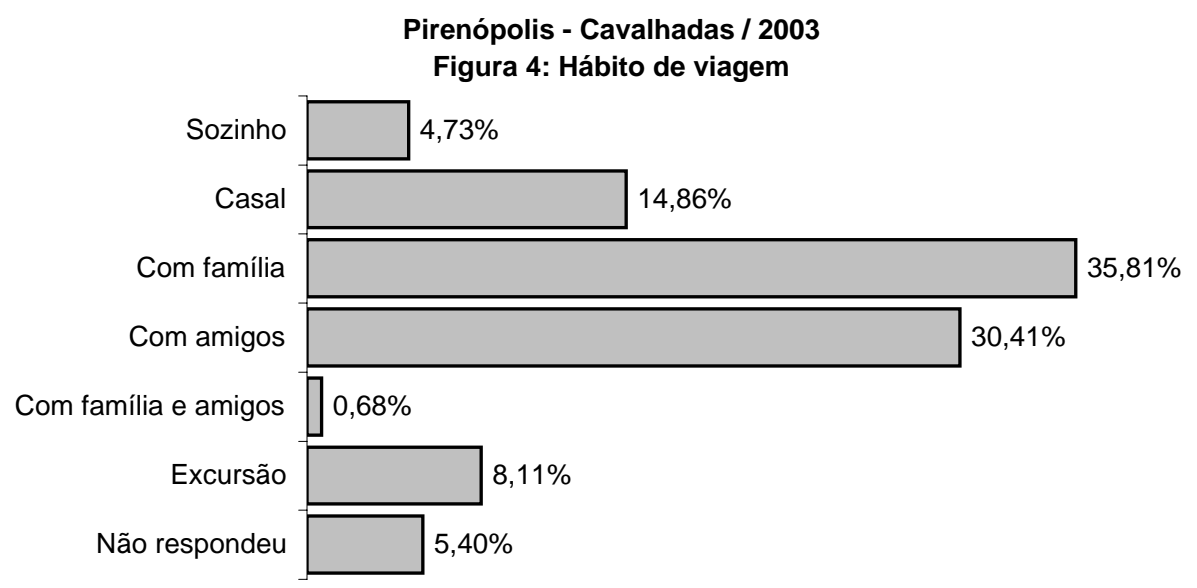

(questionários respondidos $=140$ ) 


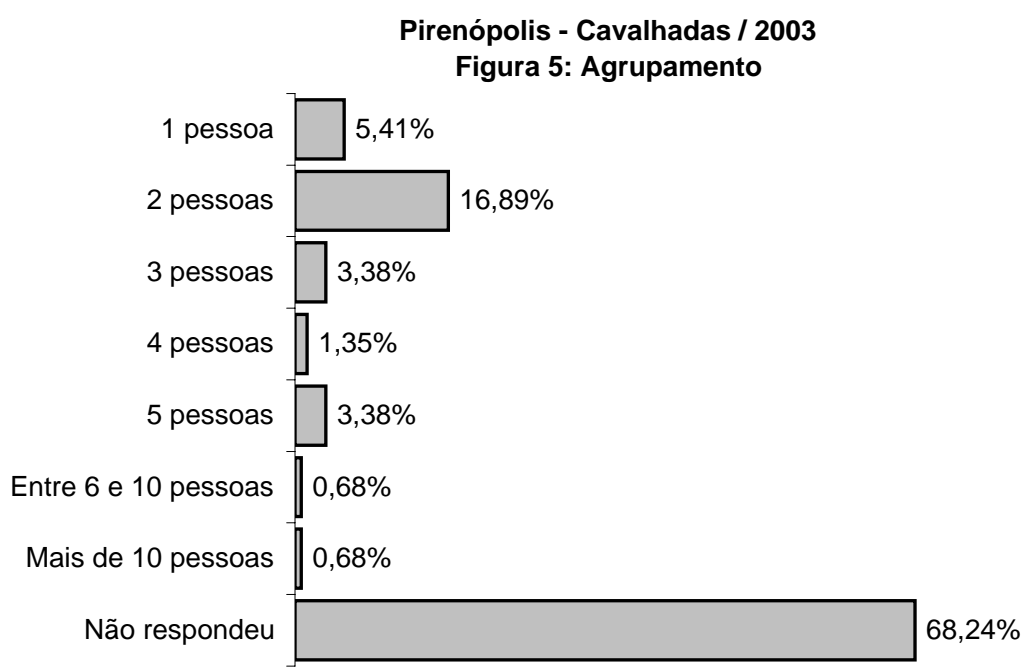

(questionários respondidos $=47$ )

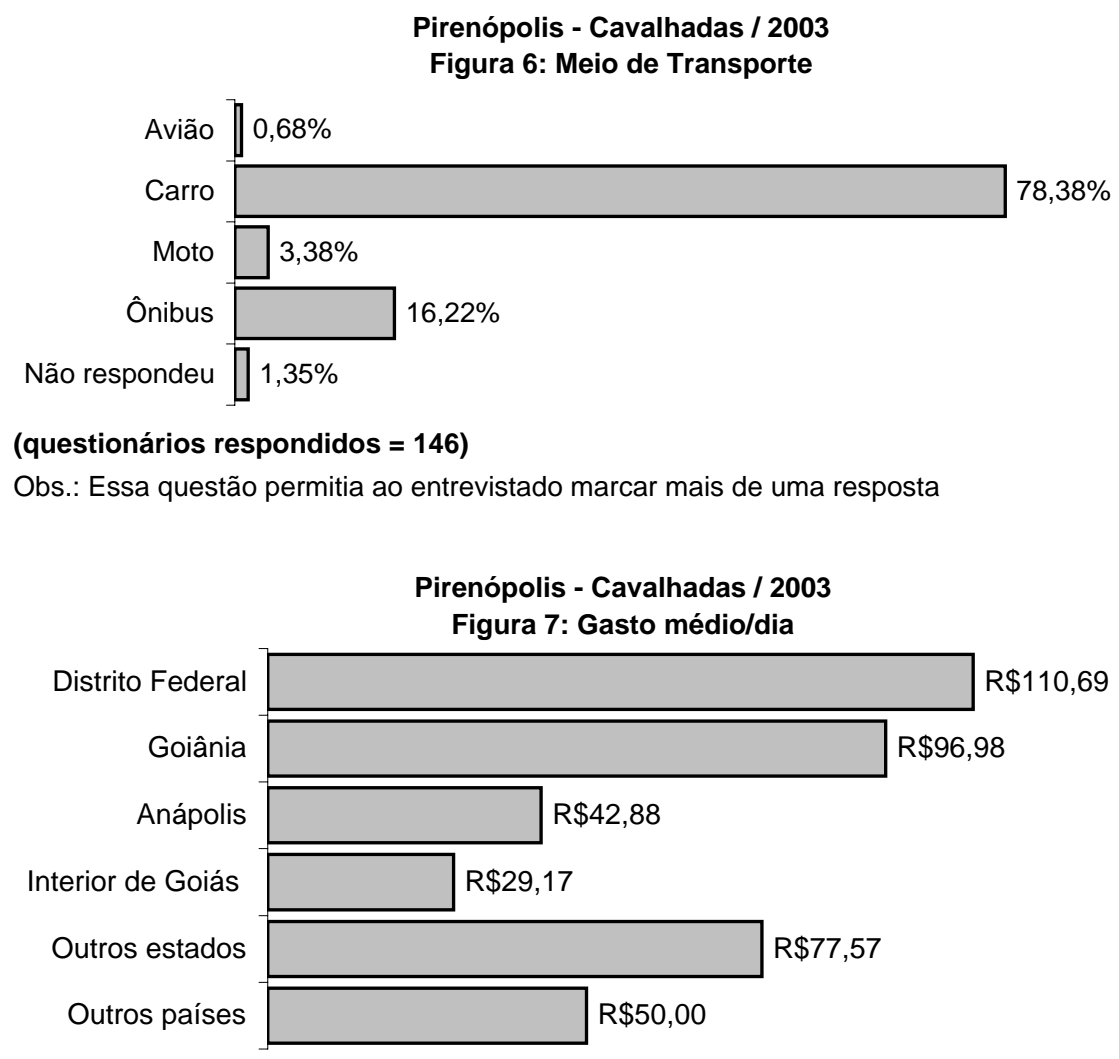

(questionários respondidos $=117$ ) 
Pirenópolis - Cavalhadas / 2003

Figura 8: Local de hospedagem

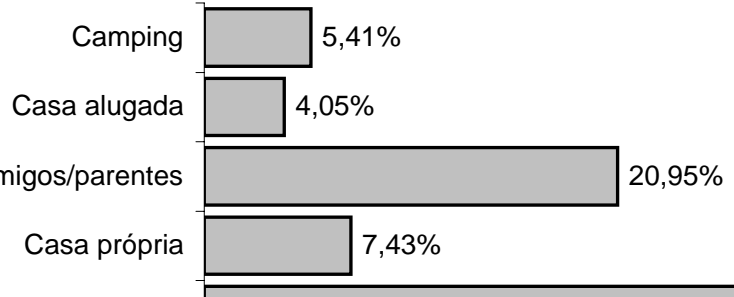

Hotel/pousada/apart-hotel

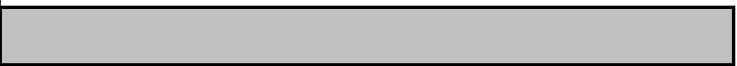

$37,16 \%$

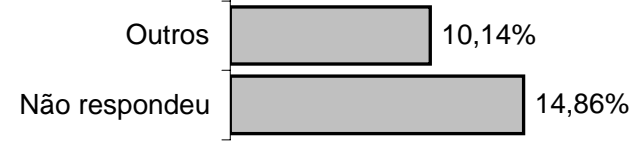

(questionários respondidos = 126)

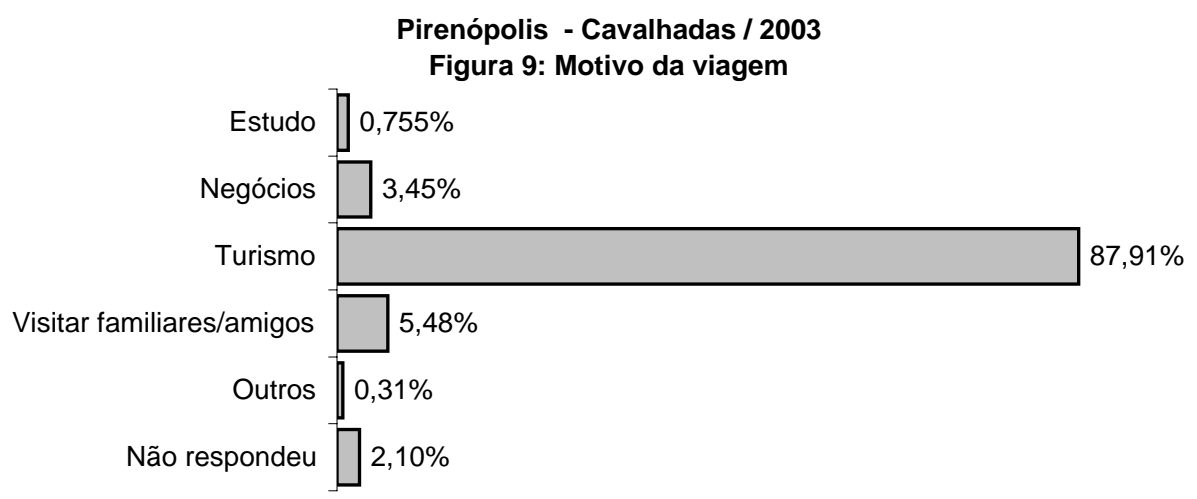

(questionários respondidos = 144)

Obs.: Essa questão permitia ao entrevistado marcar mais de uma resposta

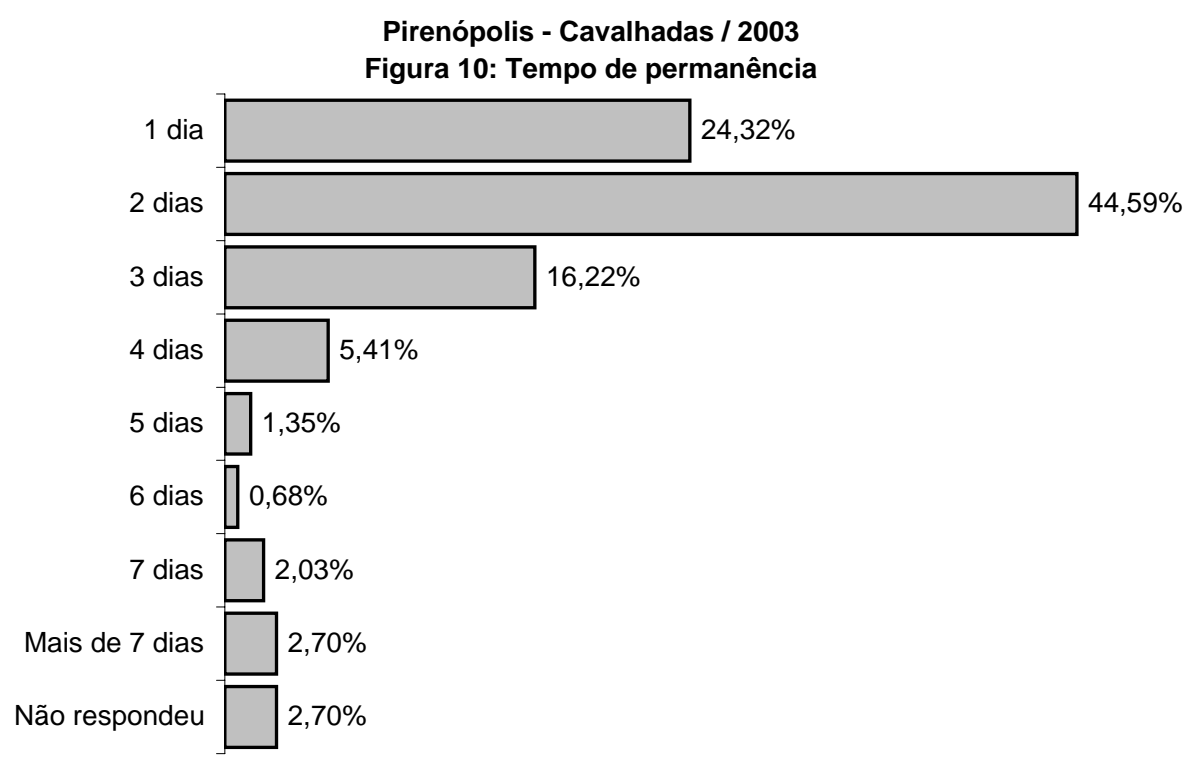

(questionários respondidos = 144) 
Pirenópolis - Cavalhadas / 2003

Figura 11: Meios de comunicação

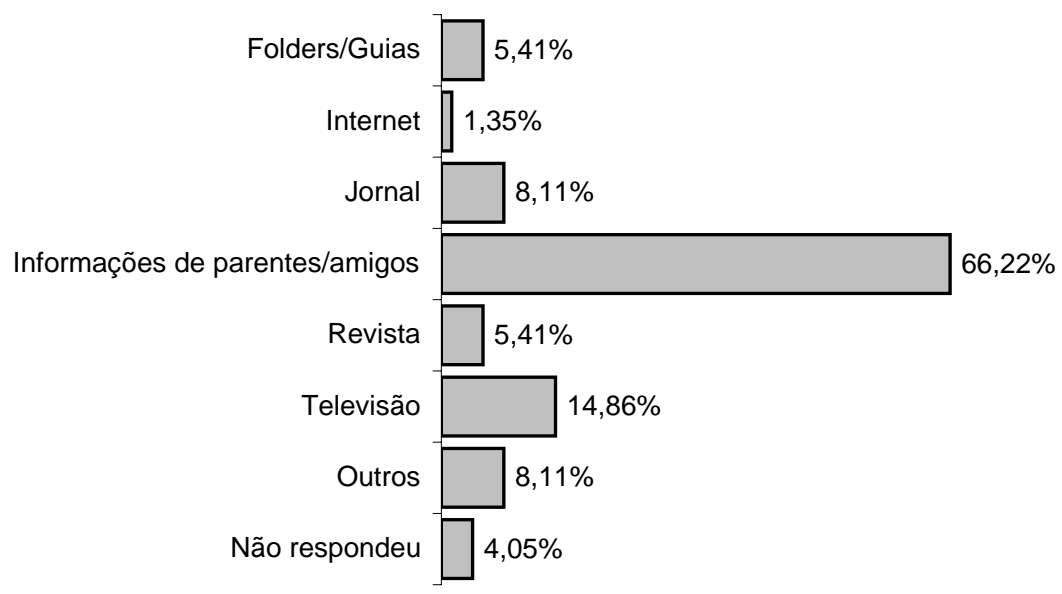

(questionários respondidos $\mathbf{= 1 4 2}$ )

Obs.: Essa questão permitia ao entrevistado marcar mais de uma resposta

Pirenópolis - Cavalhadas / 2003

Figura 12: Escolaridade

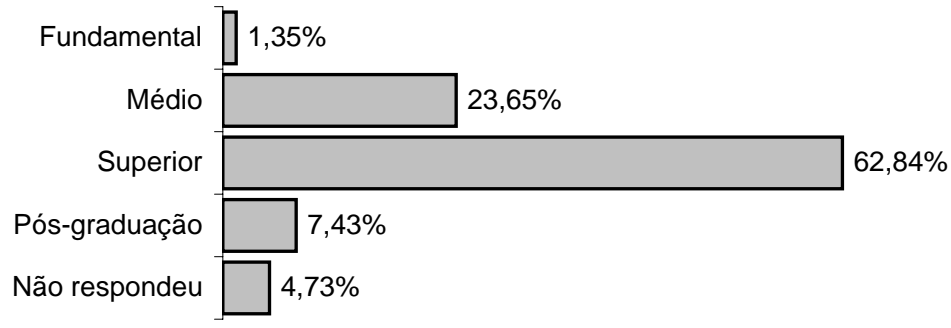

(questionários respondidos $\mathbf{= 1 4 1}$ )

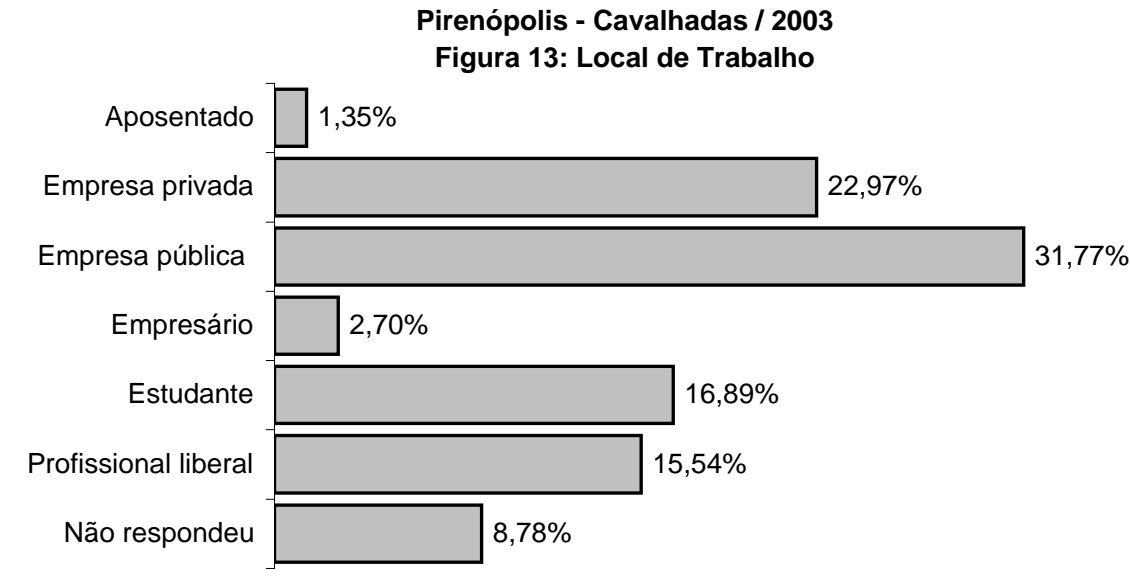

(questionários respondidos $\mathbf{= 1 3 5}$ )

Obs.: Essa questão permitia ao entrevistado marcar mais de uma resposta 
Pirenópolis - Cavalhadas / 2003

Figura 14: Renda pessoal

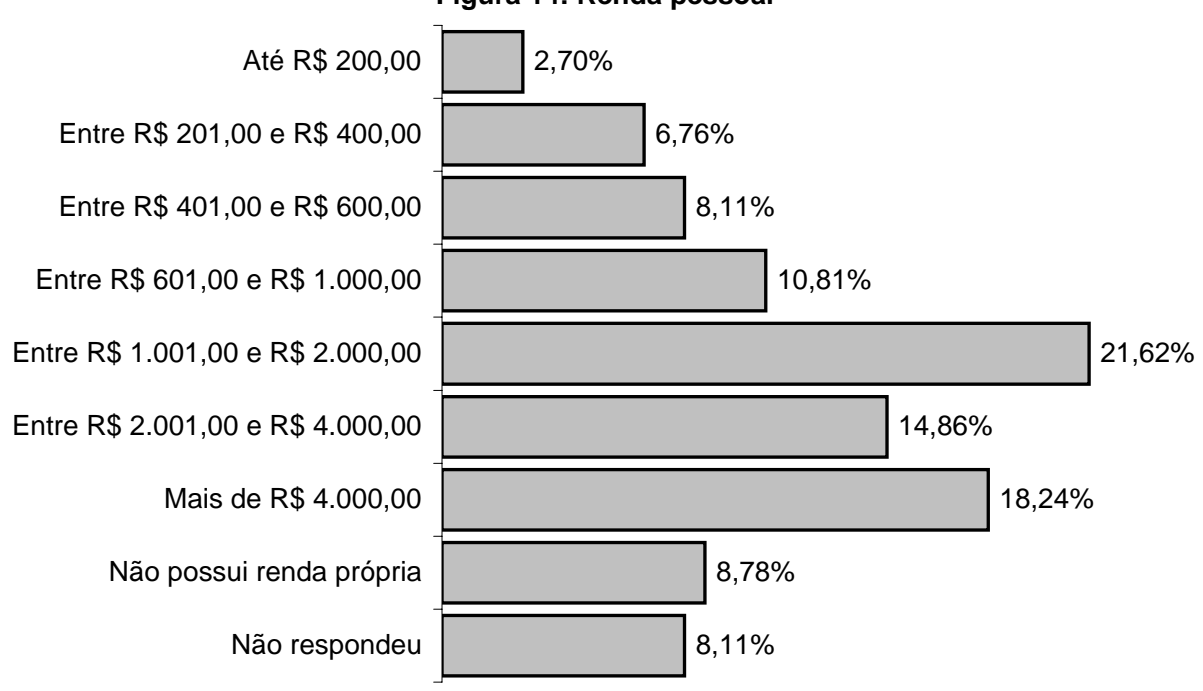

(questionários respondidos $=136$ )

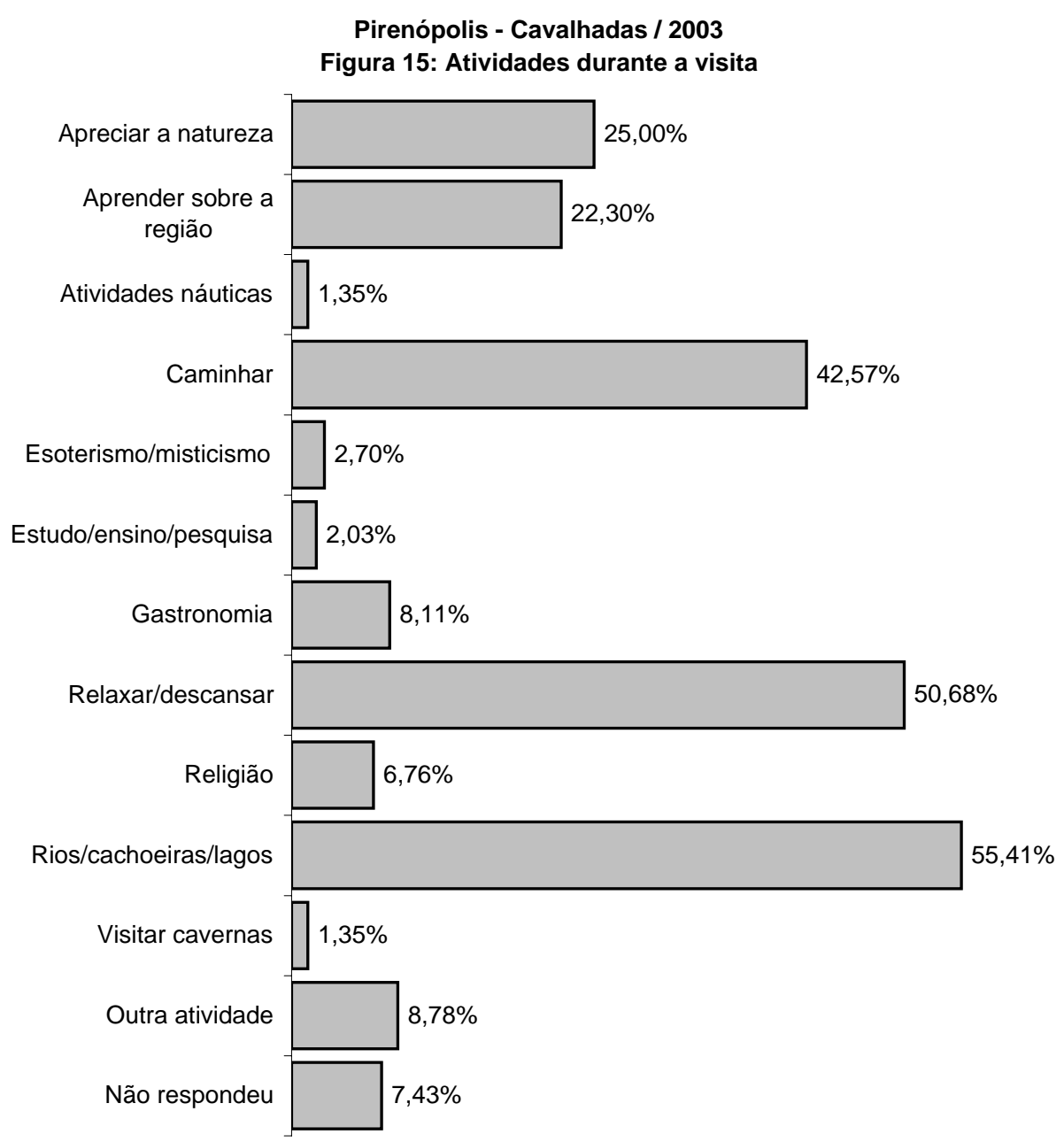

(questionários respondidos $=137$ )

Obs.: Essa questão permitia ao entrevistado marcar mais de uma resposta 
Pirenópolis - Cavalhadas / 2003

Figura 16: Já visitou o município

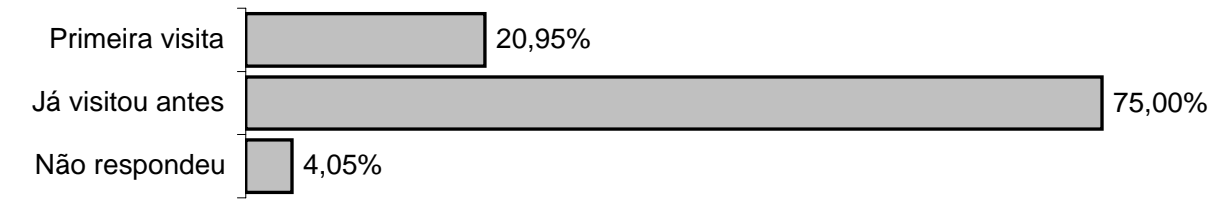

(questionários respondidos $=142$ )

Pirenópolis - Cavalhadas / 2003

Figura 17: Pretende voltar ao município

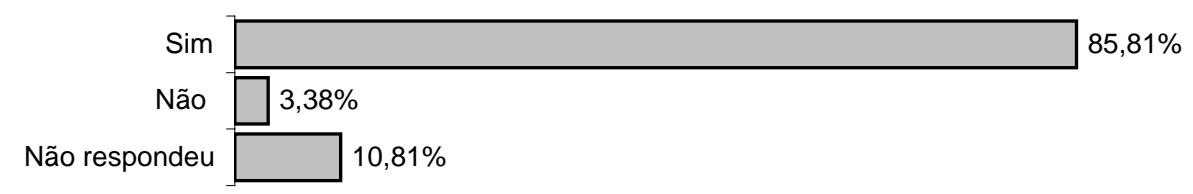

(questionários respondidos $=132$ )

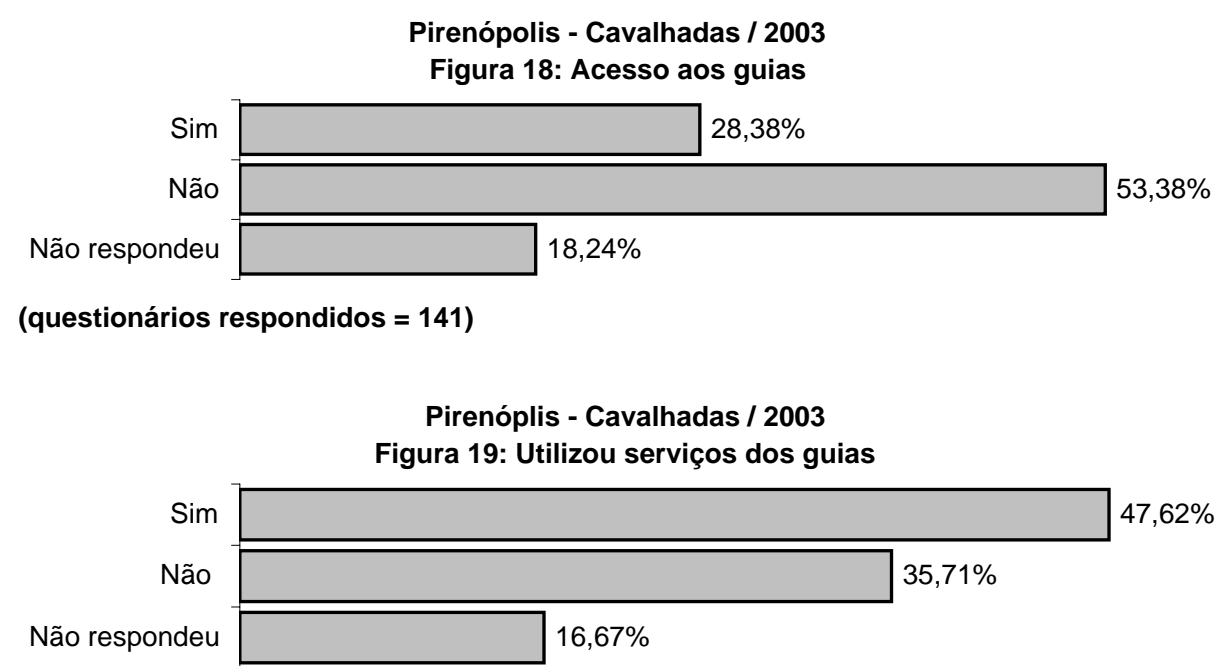

(questionários respondidos = 123)

Pirenópolis - Cavalhadas / 2003

Figura 20: Avaliação dos serviços dos guias

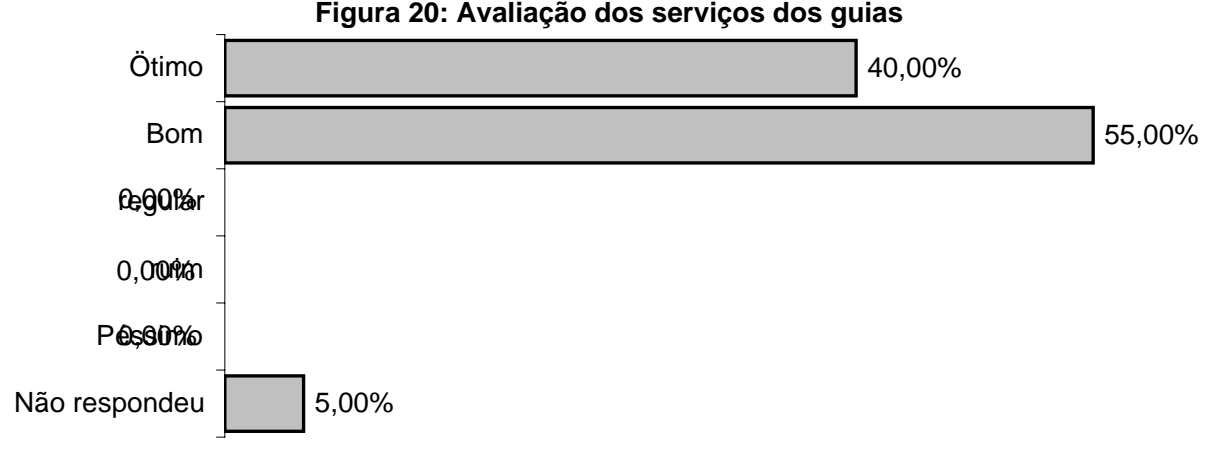

(questionários respondidos $=141$ ) 


\section{Festa do Divino (Cavalhadas) - Percepção do Visitante}

AVALIAÇÃO DA INFRA-ESTRUTURA

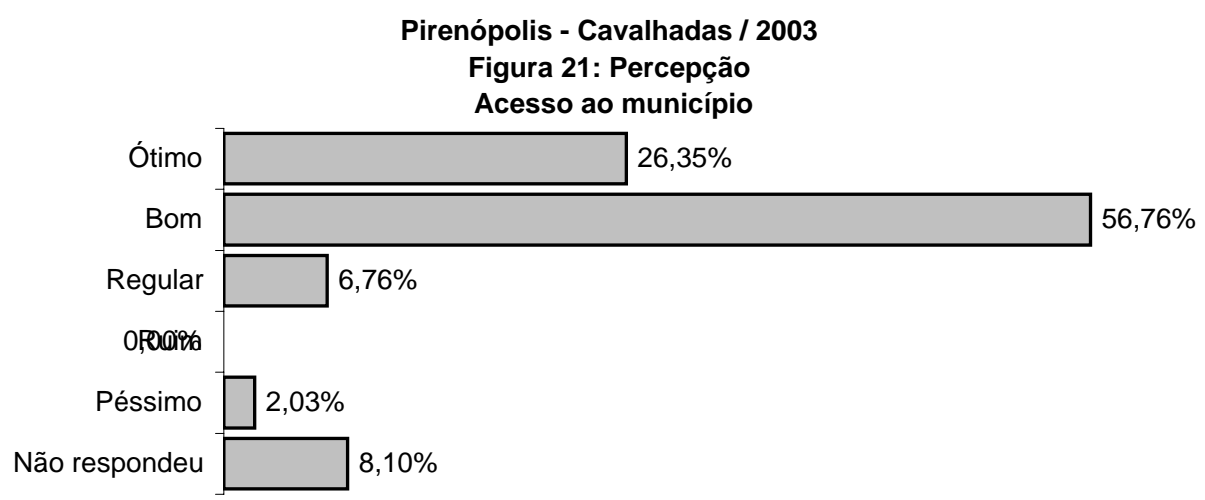

(questionários respondidos = 136)

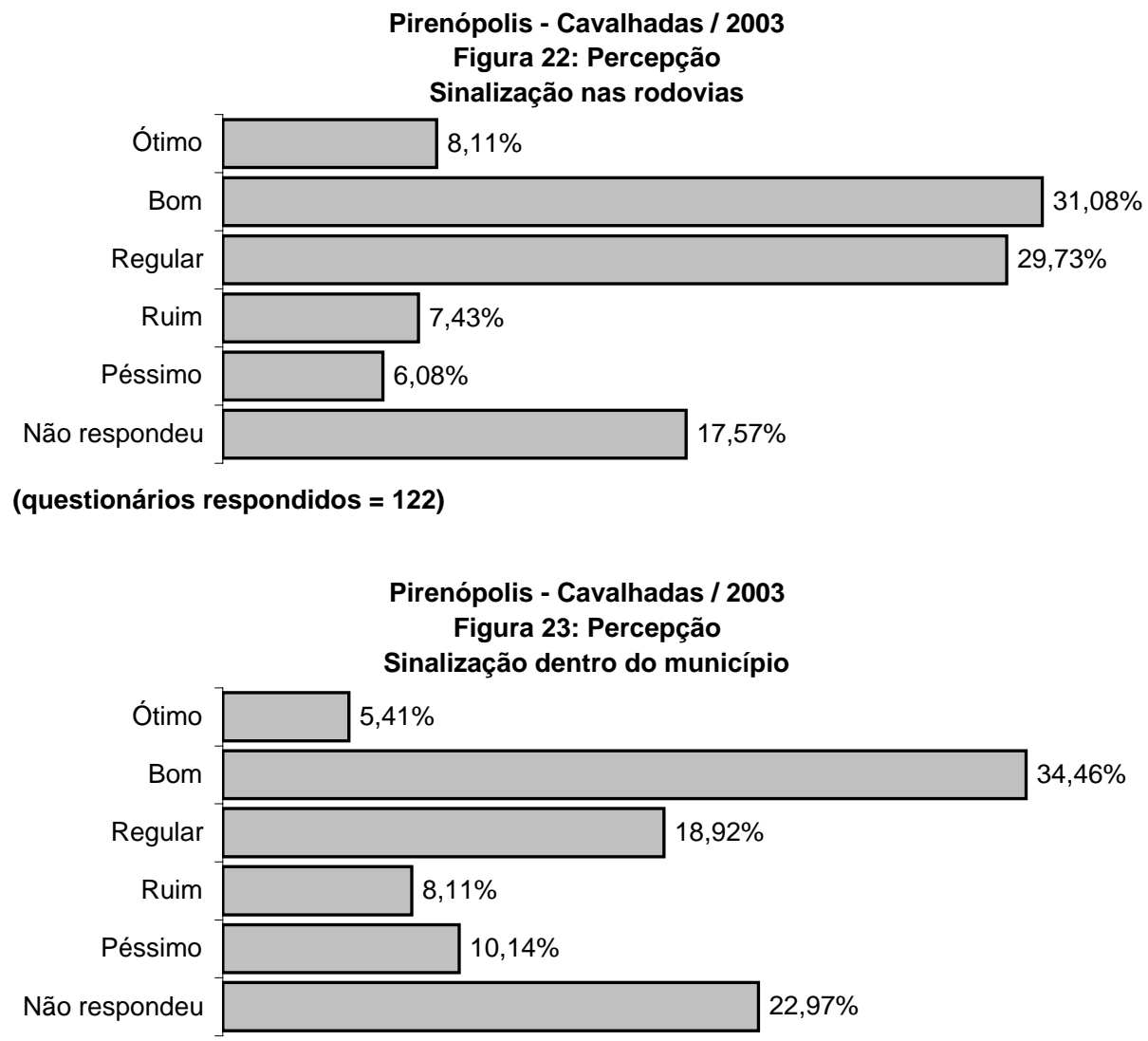

(questionários respondidos $=114$ ) 


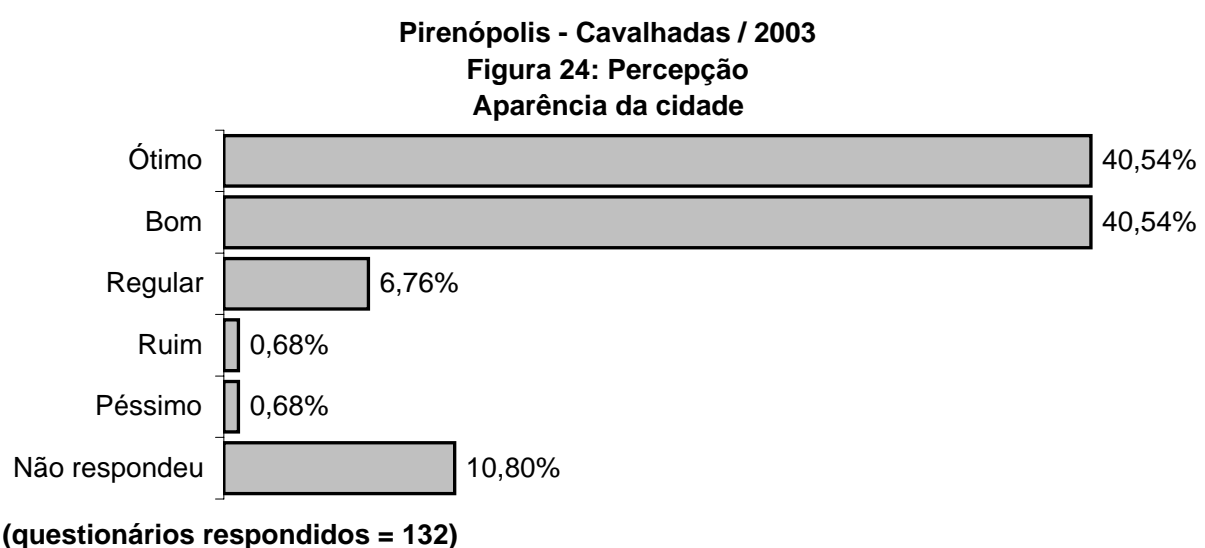

(questionários respondidos $=132$ )

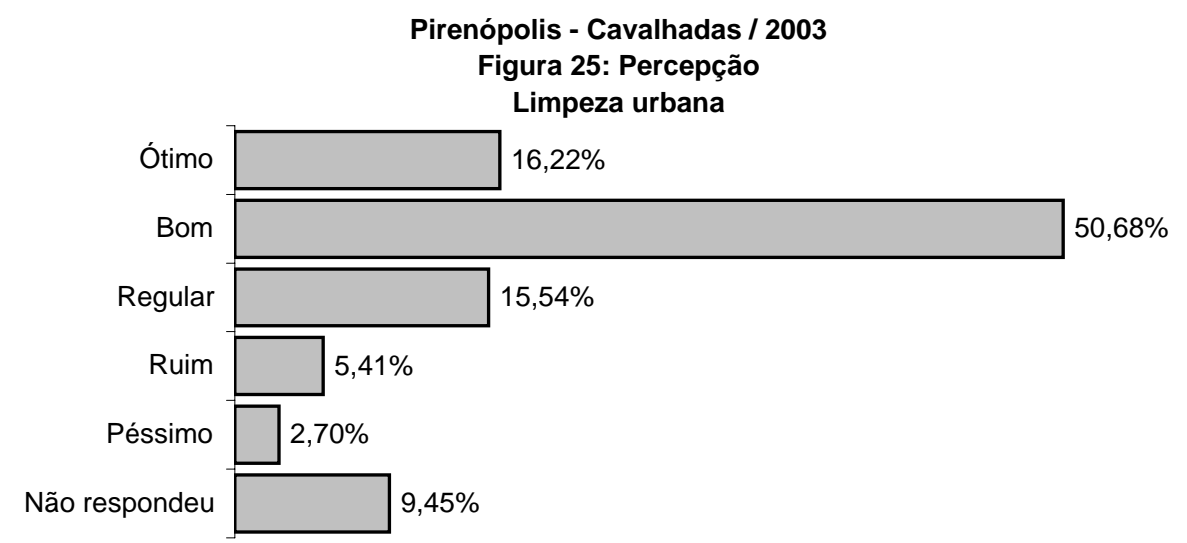

(questionários respondidos $=134$ )

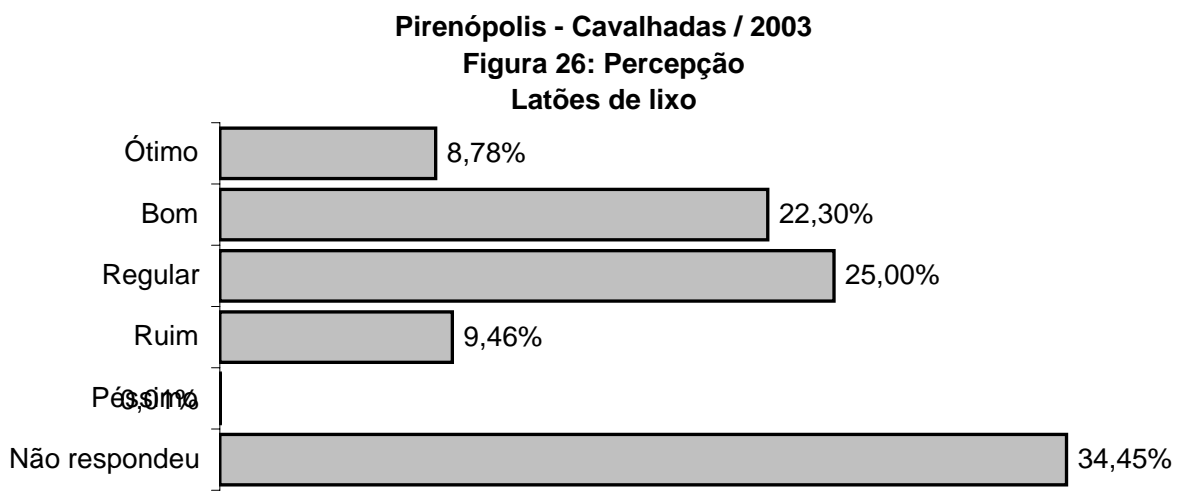

(questionários respondidos $=97$ ) 


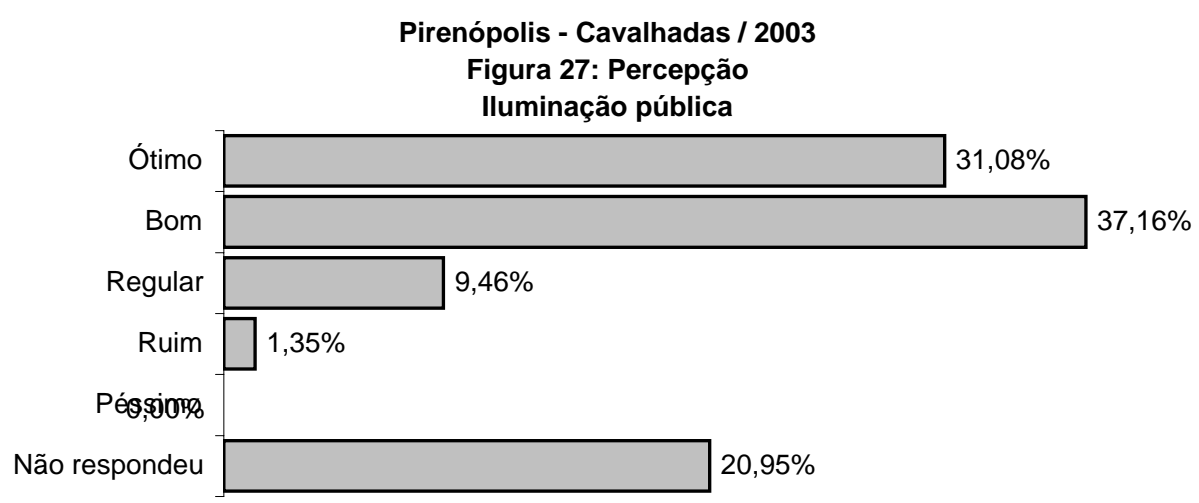

(questionários respondidos $=117$ )

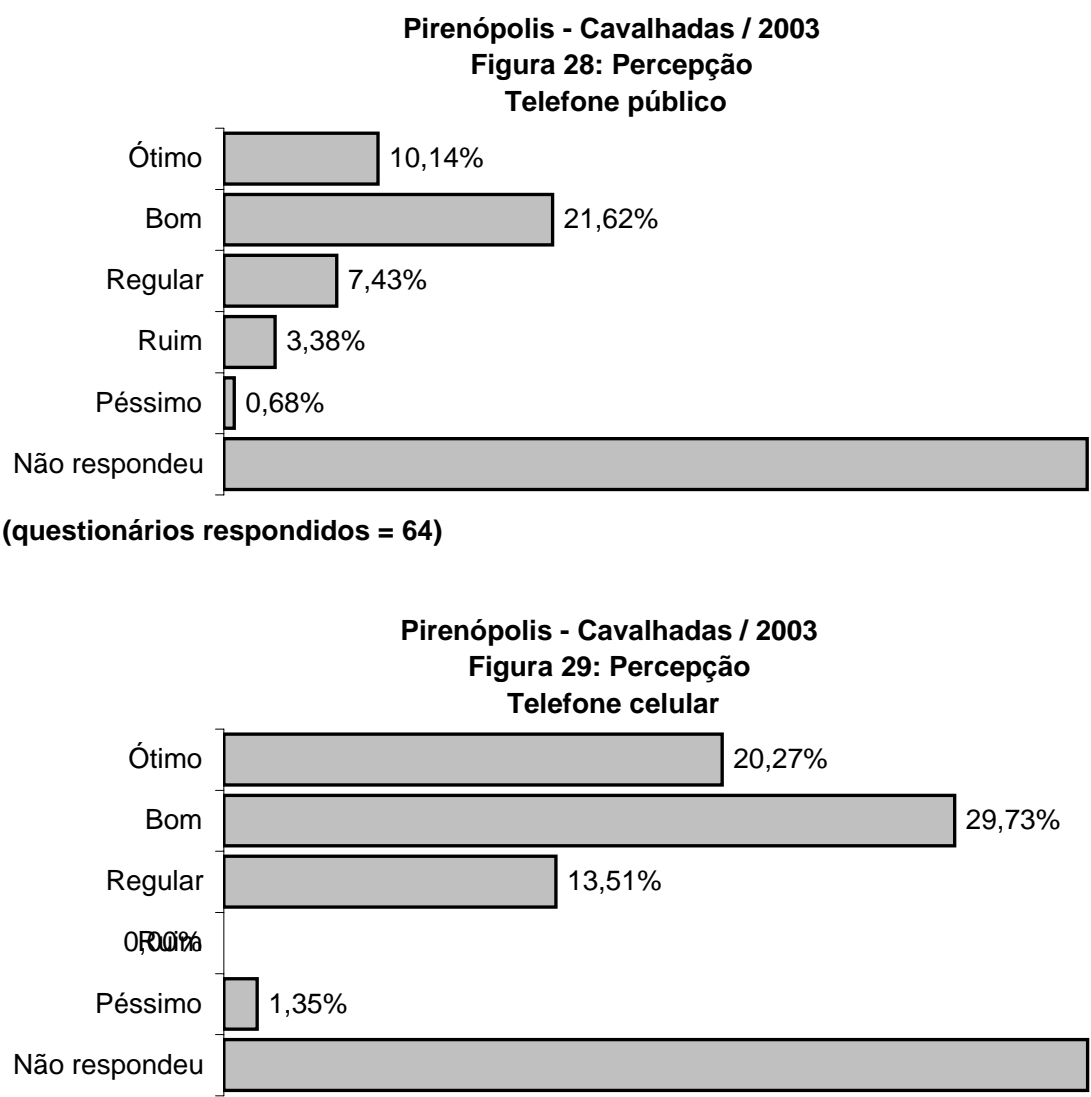

(questionários respondidos $=96$ ) 


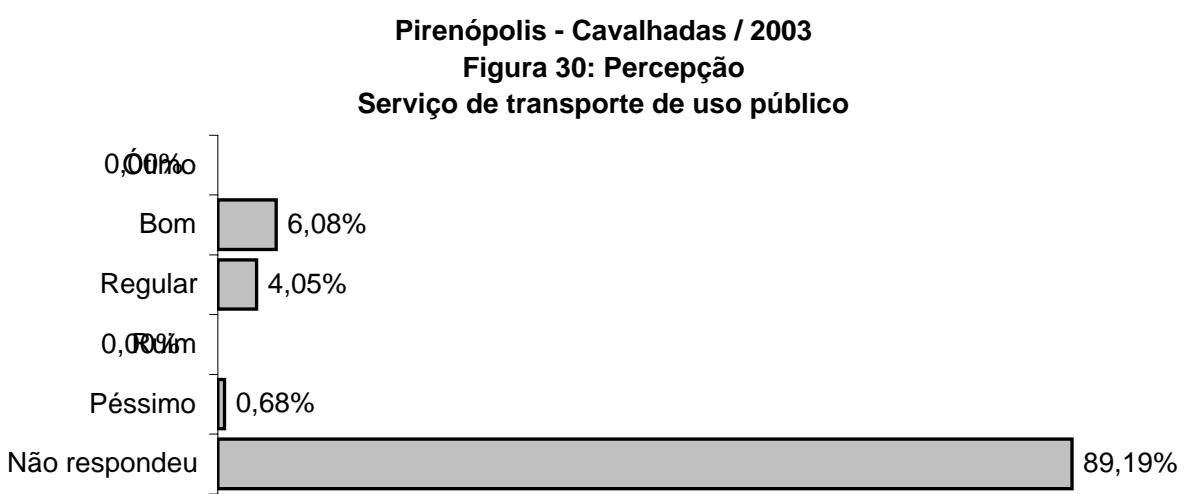

(questionários respondidos $=16$ )
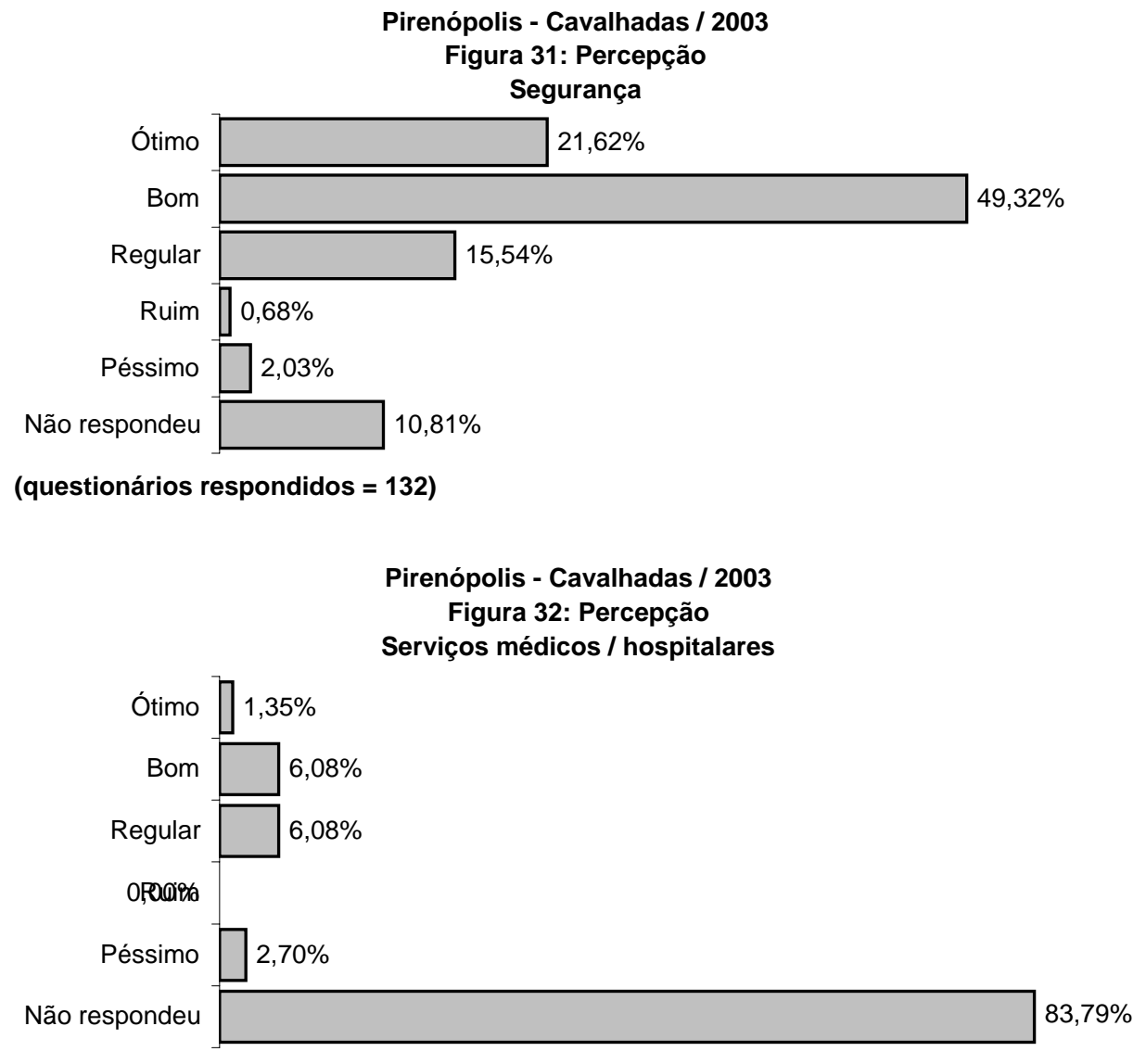

(questionários respondidos $=24$ ) 


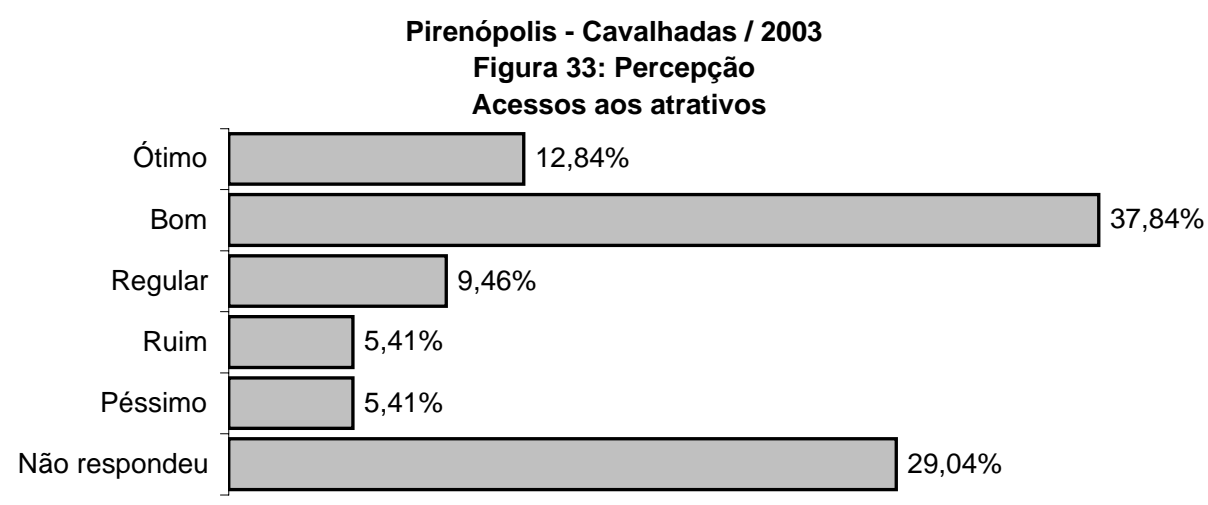

(questionários respondidos $=105$ )

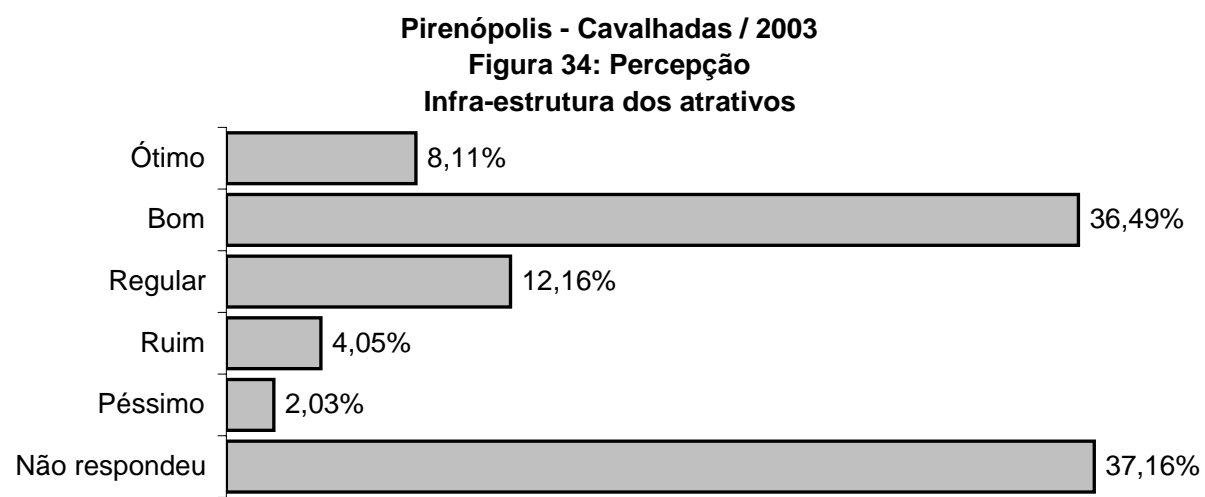

(questionários respondidos $=93$ )

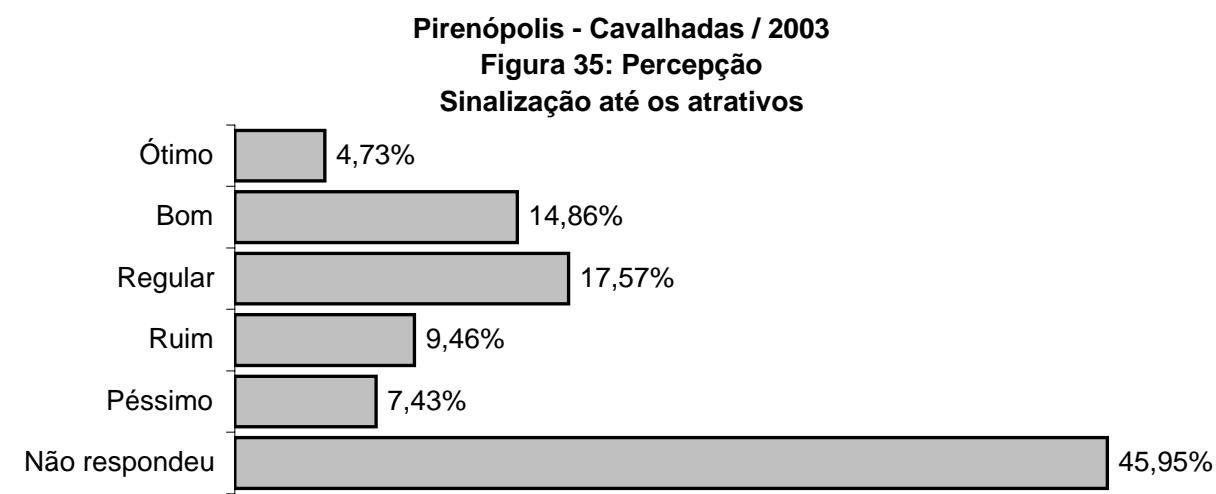

(questionários respondidos $=80$ ) 
Pirenópolis - Cavalhadas / 2003

Figura 36: Percepção

Sinalização dentro dos atrativos

\begin{tabular}{|c|c|}
\hline Ótimo & $6,08 \%$ \\
\hline Bom & $16,22 \%$ \\
\hline Regular & $13,51 \%$ \\
\hline Ruim & $6,08 \%$ \\
\hline Péssimo & $8,11 \%$ \\
\hline ão respondeu & \\
\hline
\end{tabular}

$50,00 \%$

(questionários respondidos $=74$ )

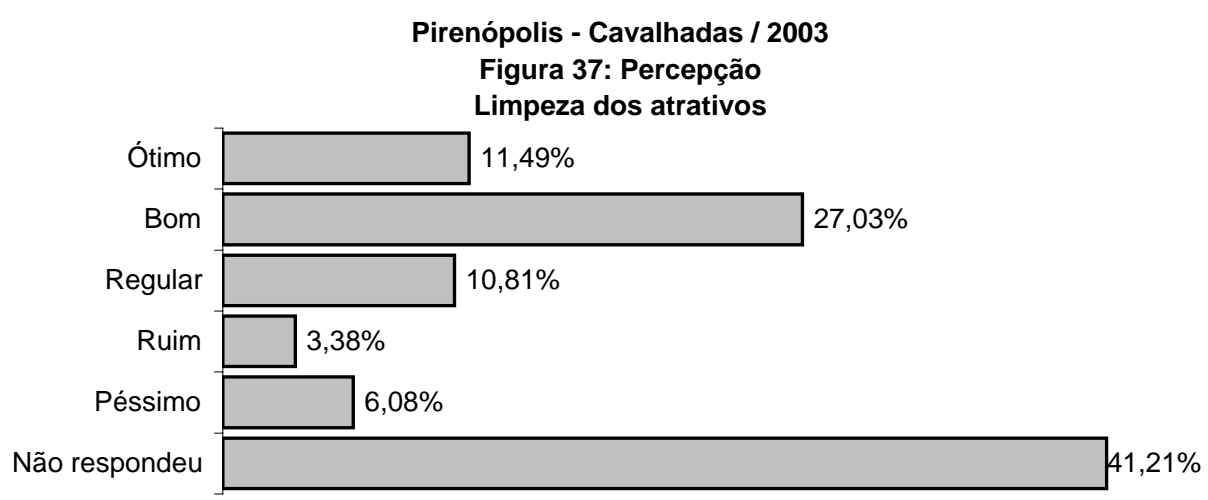

(questionários respondidos $=87$ )

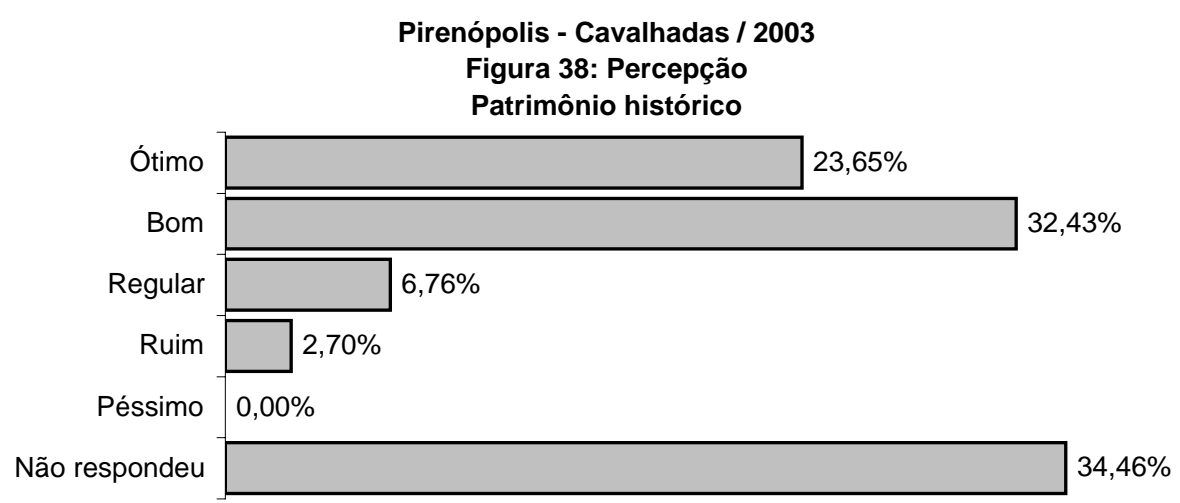

(questionários respondidos $=97$ ) 


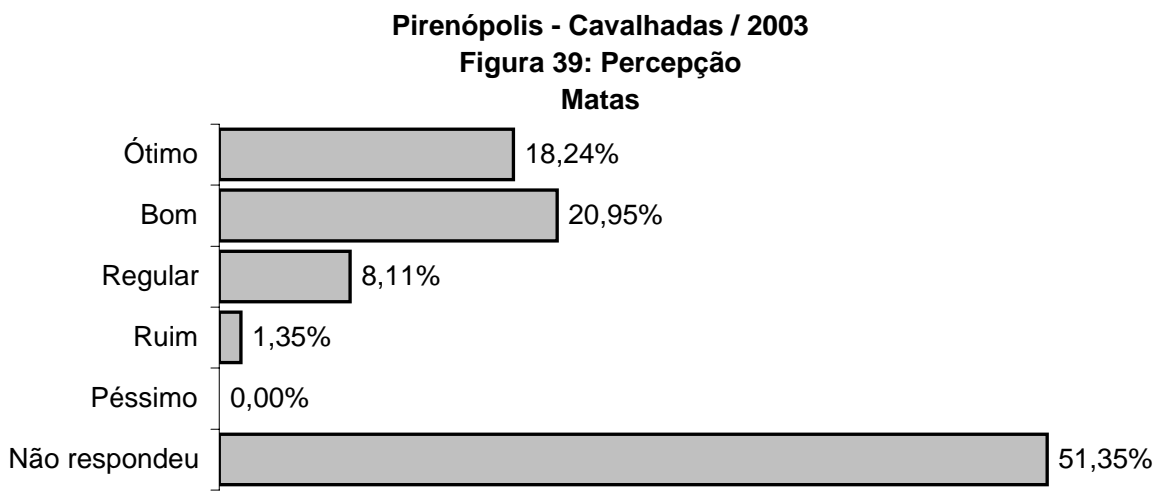

(questionários respondidos $=72$ )

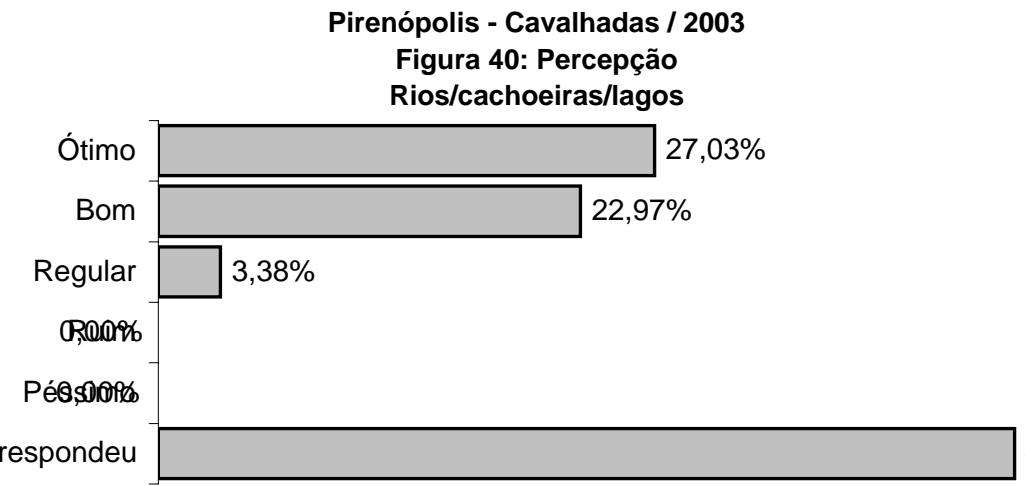

$46,62 \%$

(questionários respondidos $=79$ )

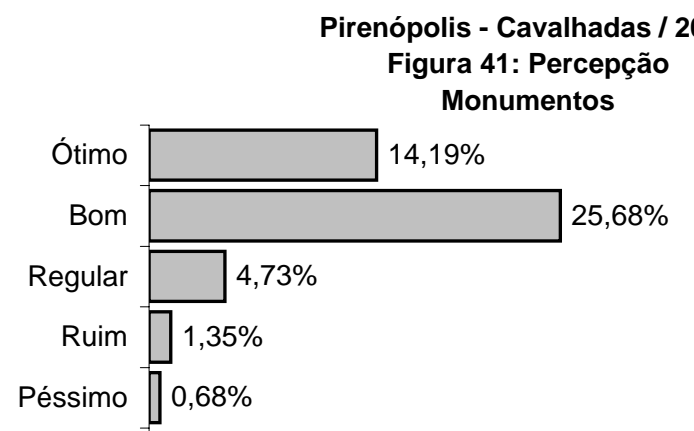

Não respondeu

$53,38 \%$

(questionários respondidos $=69$ ) 


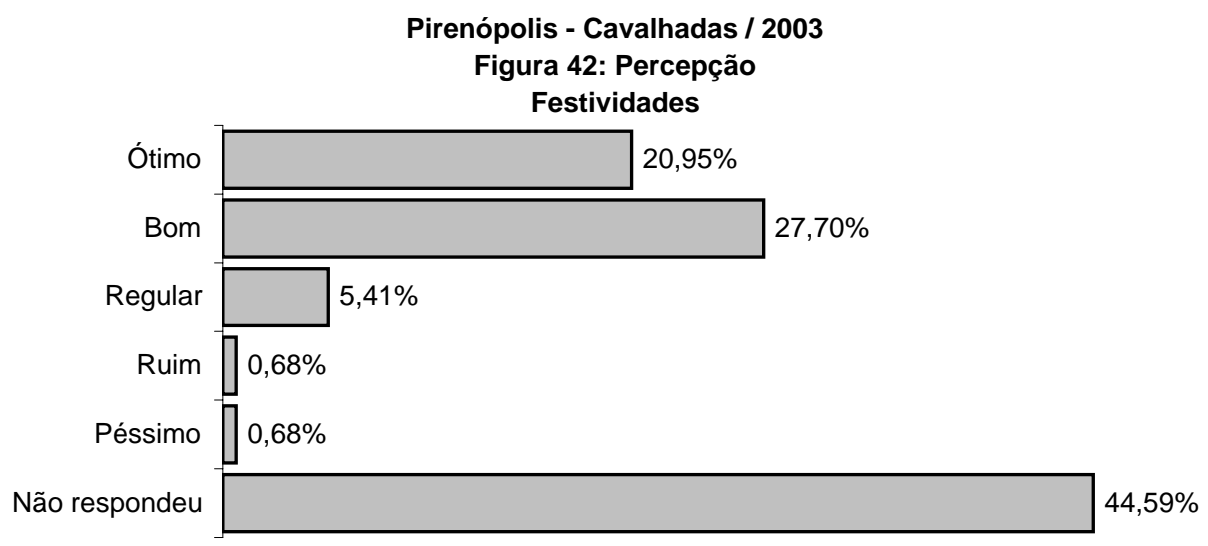

(questionários respondidos $=82$ )

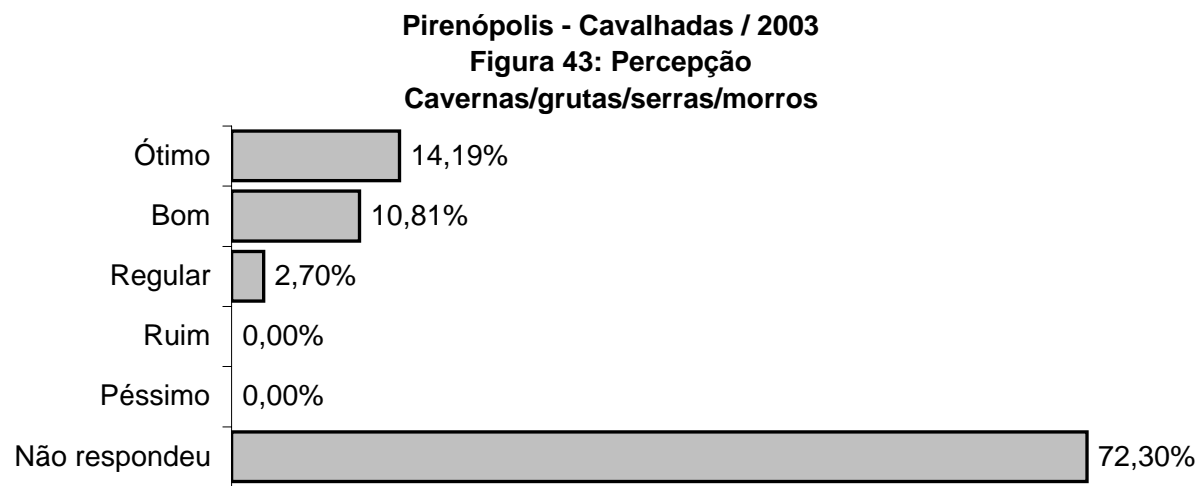

(questionários respondidos $=41$ )

\section{AVALIAÇÃO DOS EQUIPAMENTOS E SERVIÇOS TURÍSTICOS}

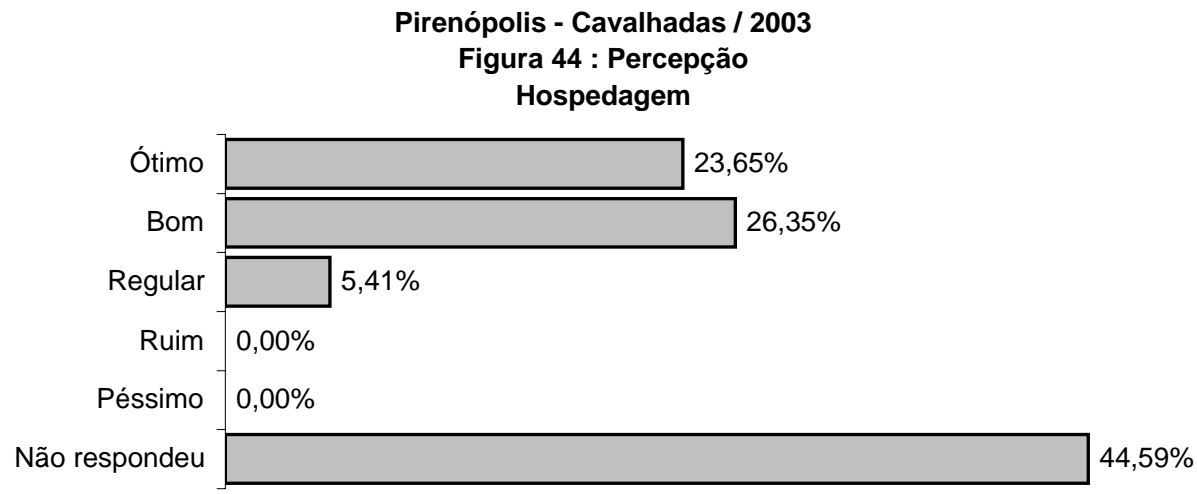

(questionários respondidos = 82) 


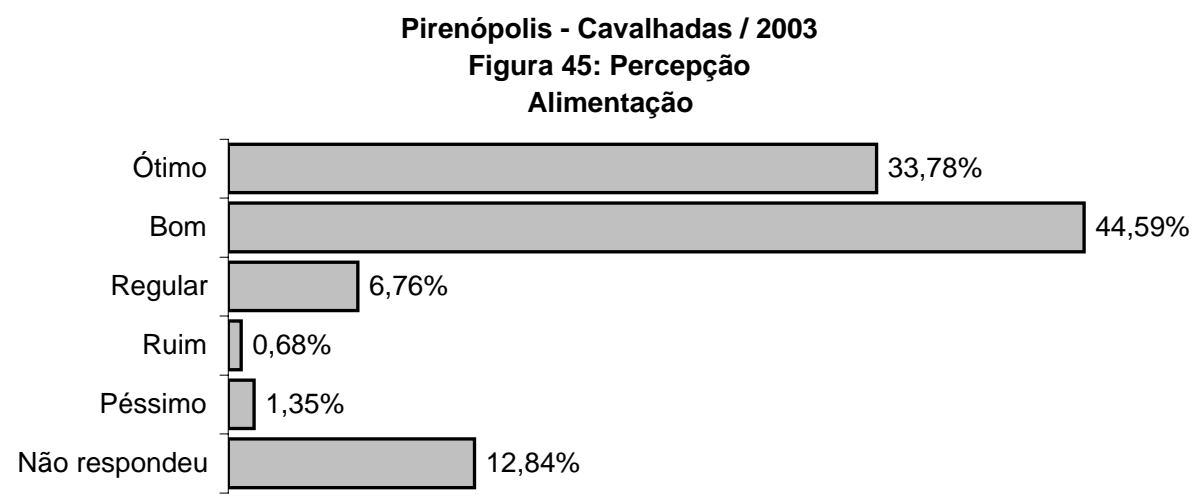

(questionários respondidos = 129)

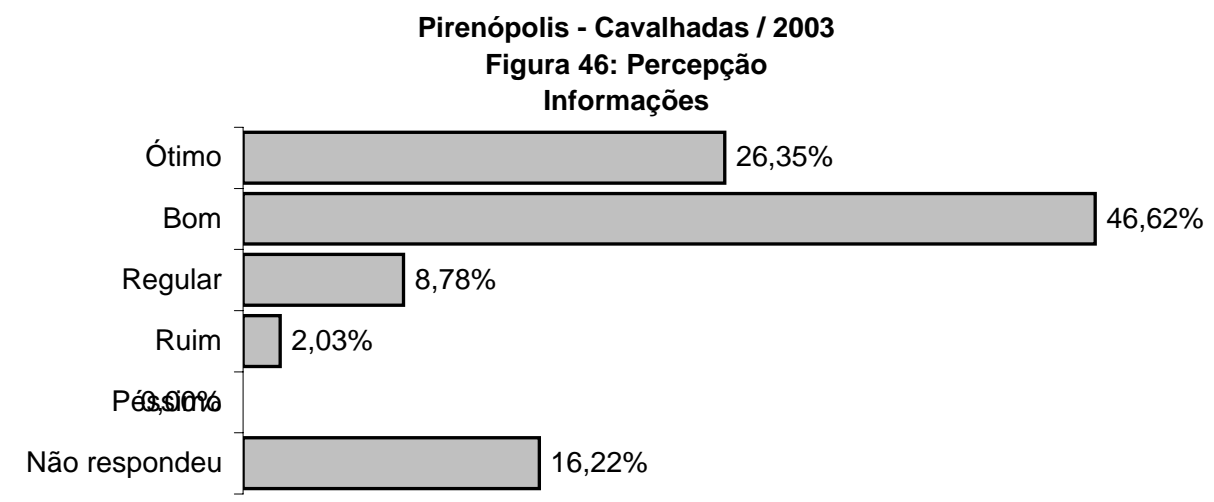

(questionários respondidos $=124$ )

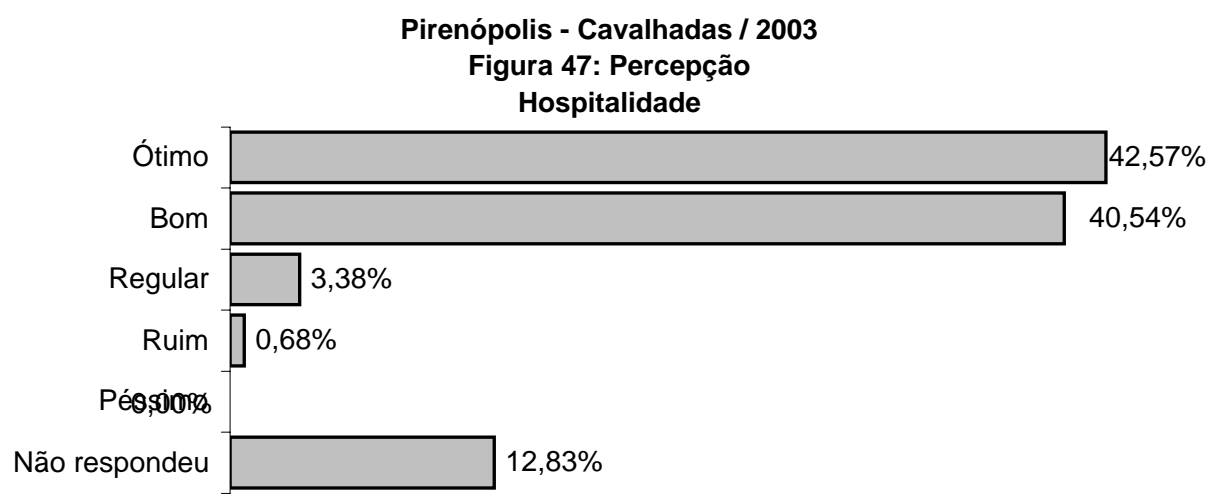

(questionários respondidos $=129$ ) 


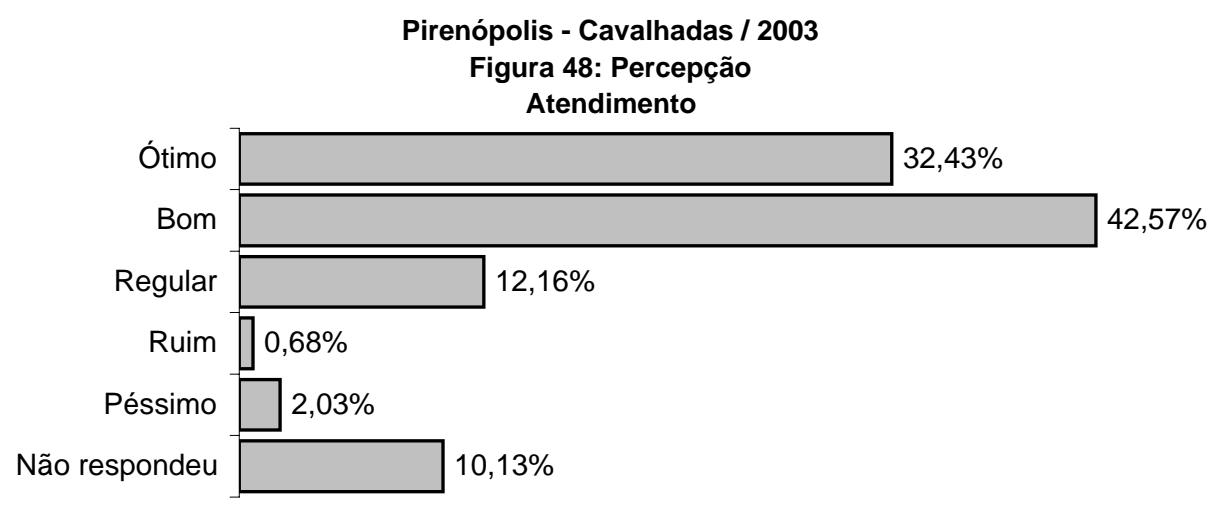

(questionários respondidos $=133$ )

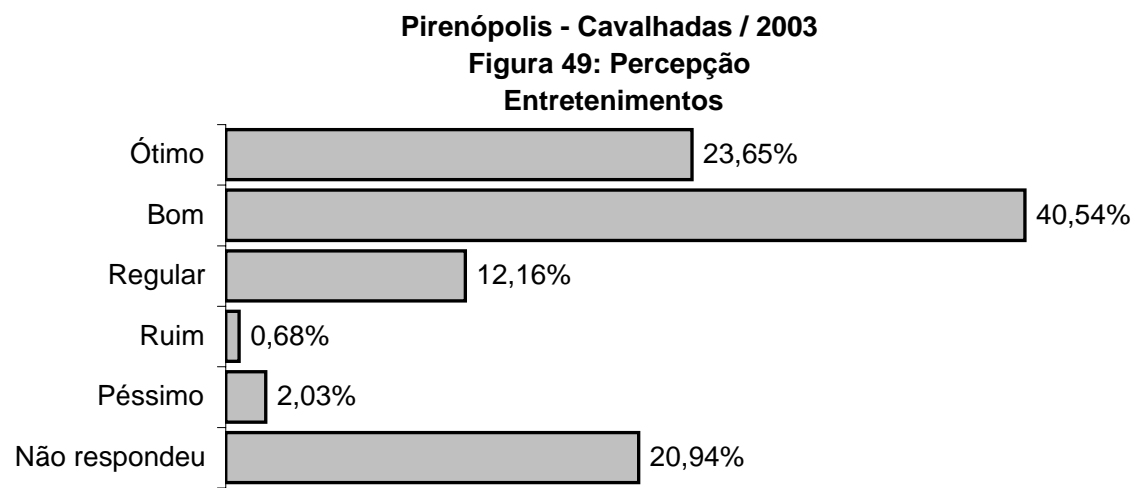

(questionários respondidos = 117)

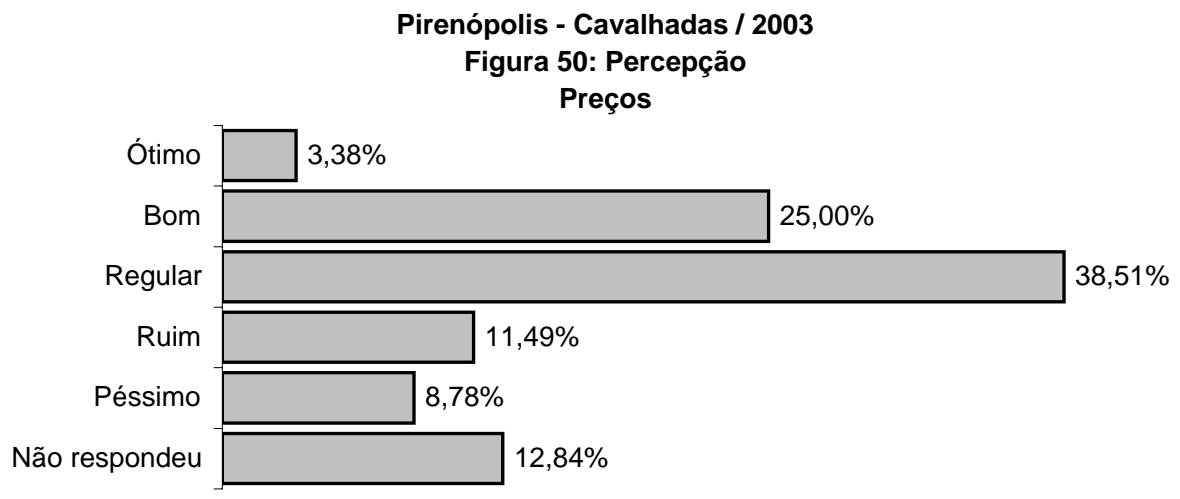




\section{Final de Semana Comum - Perfil do Visistante}

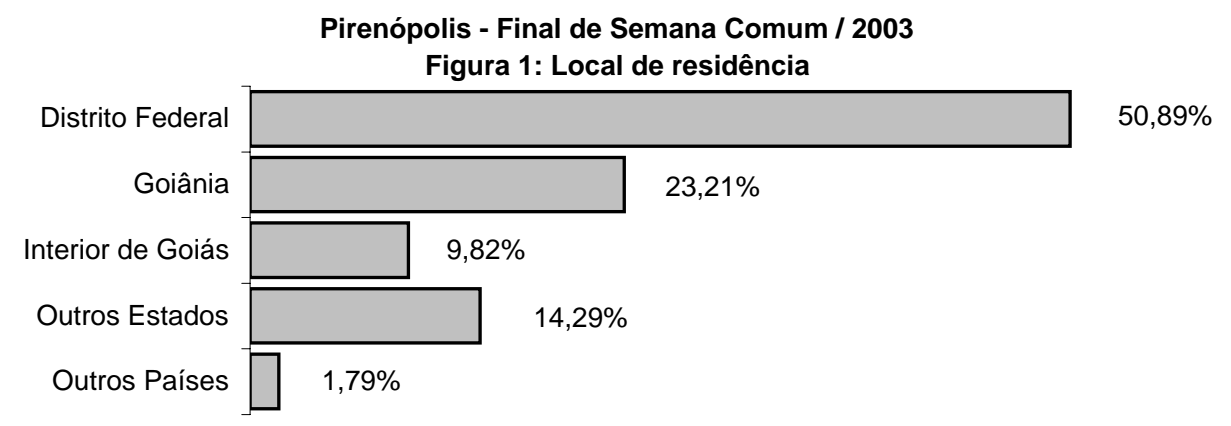

(questionários respondidos = 112)

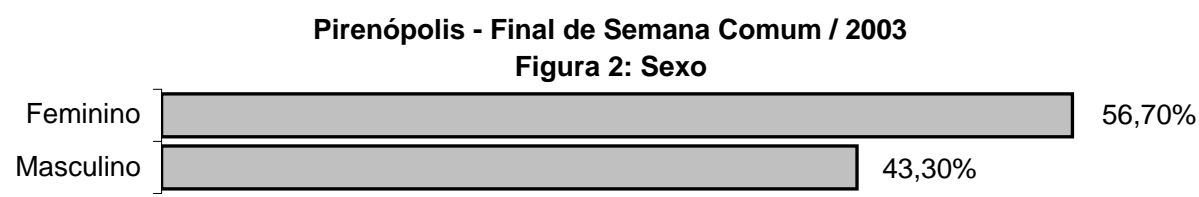

(questionários respondidos = 112)
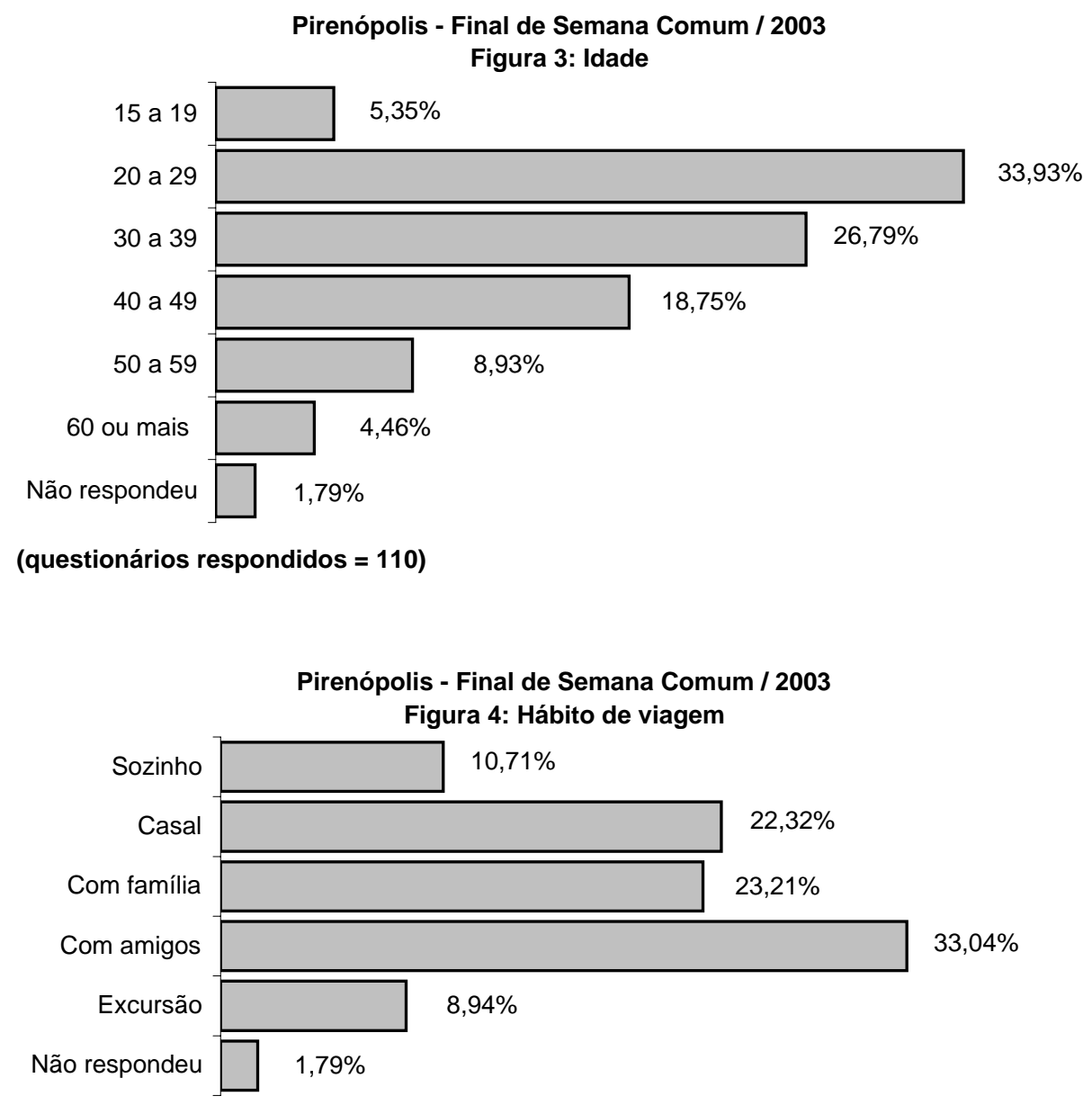

(questionários respondidos = 110) 
Pirenópolis - Final de Semana Comum / 2003

Figura 5: Meios de transporte

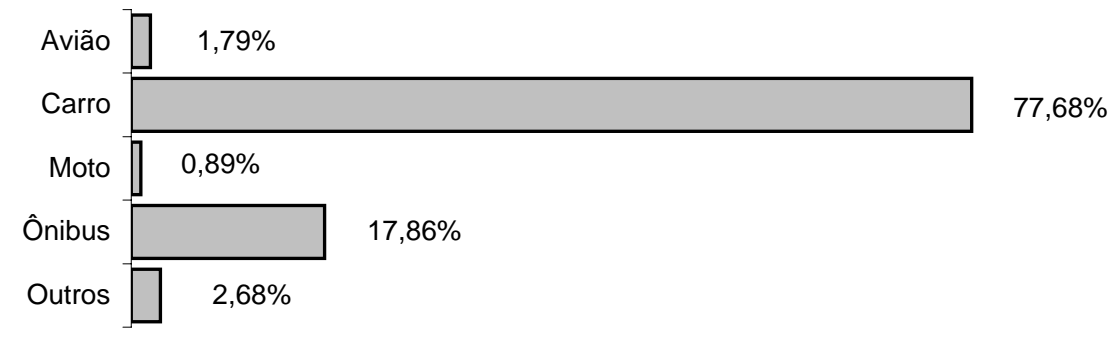

(questionários respondidos $\mathbf{= 1 1 2}$ )

Obs.: Esta questão permitia ao entrevistado marcar mais de uma resposta

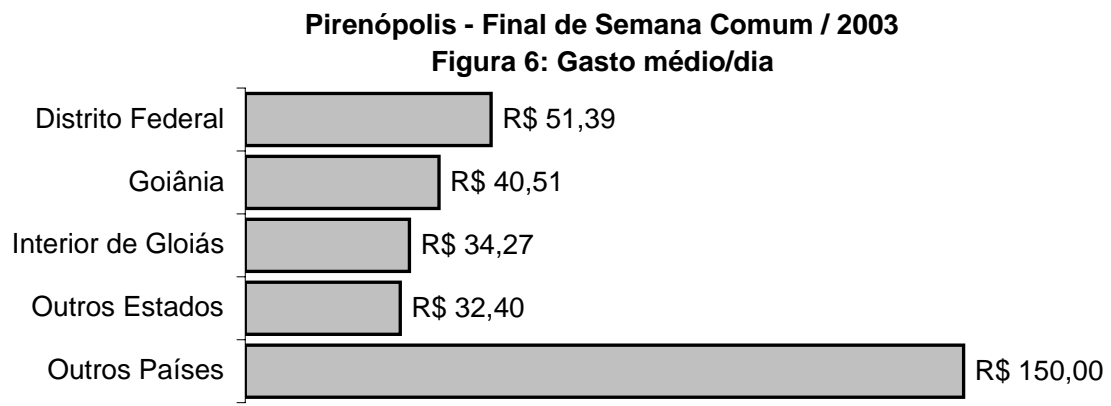

(questionários respondidos $=91$ )

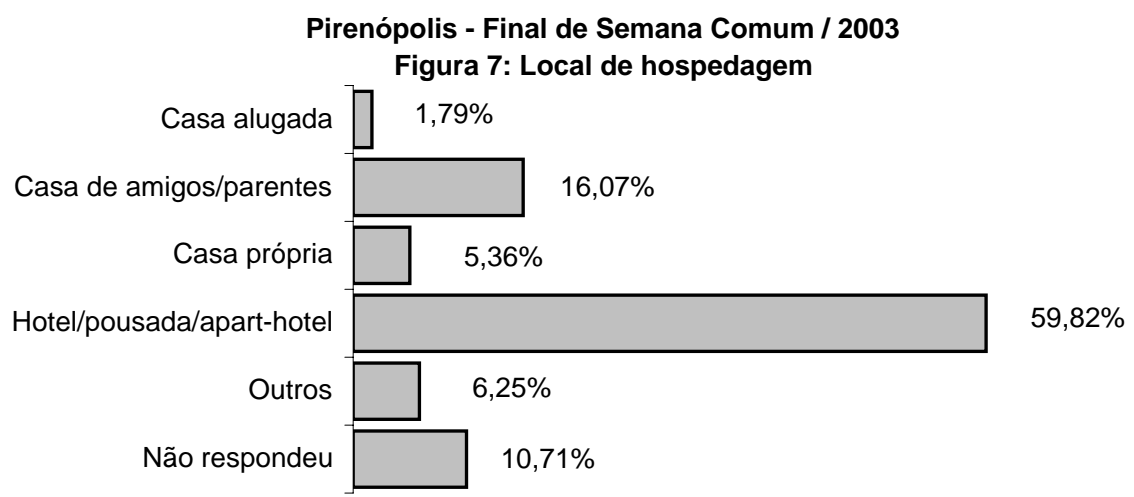

(questionários respondidos $=100$ )

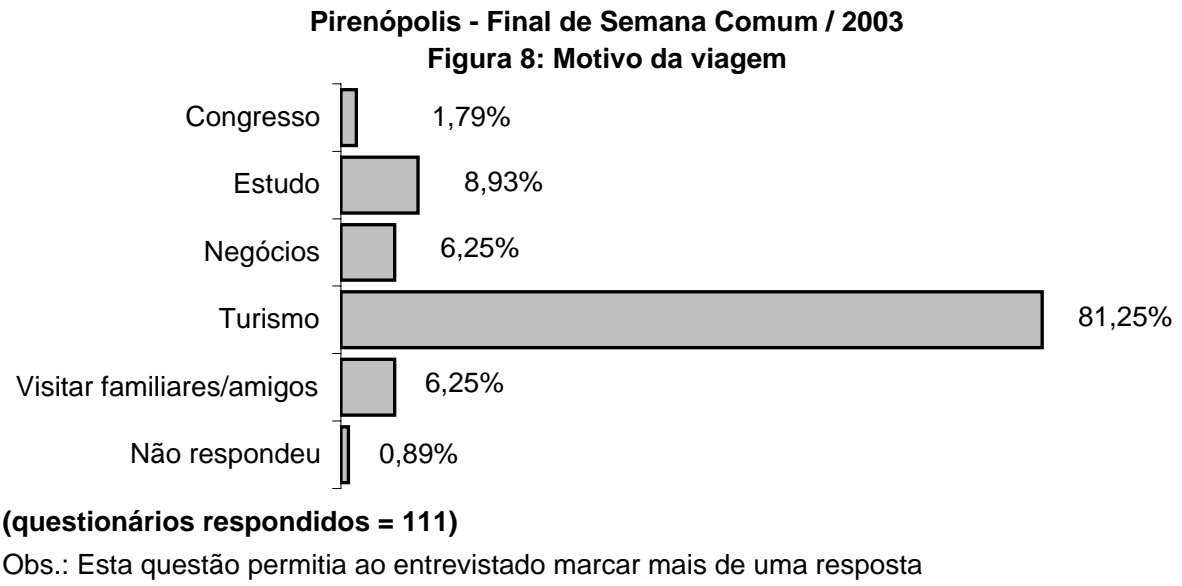




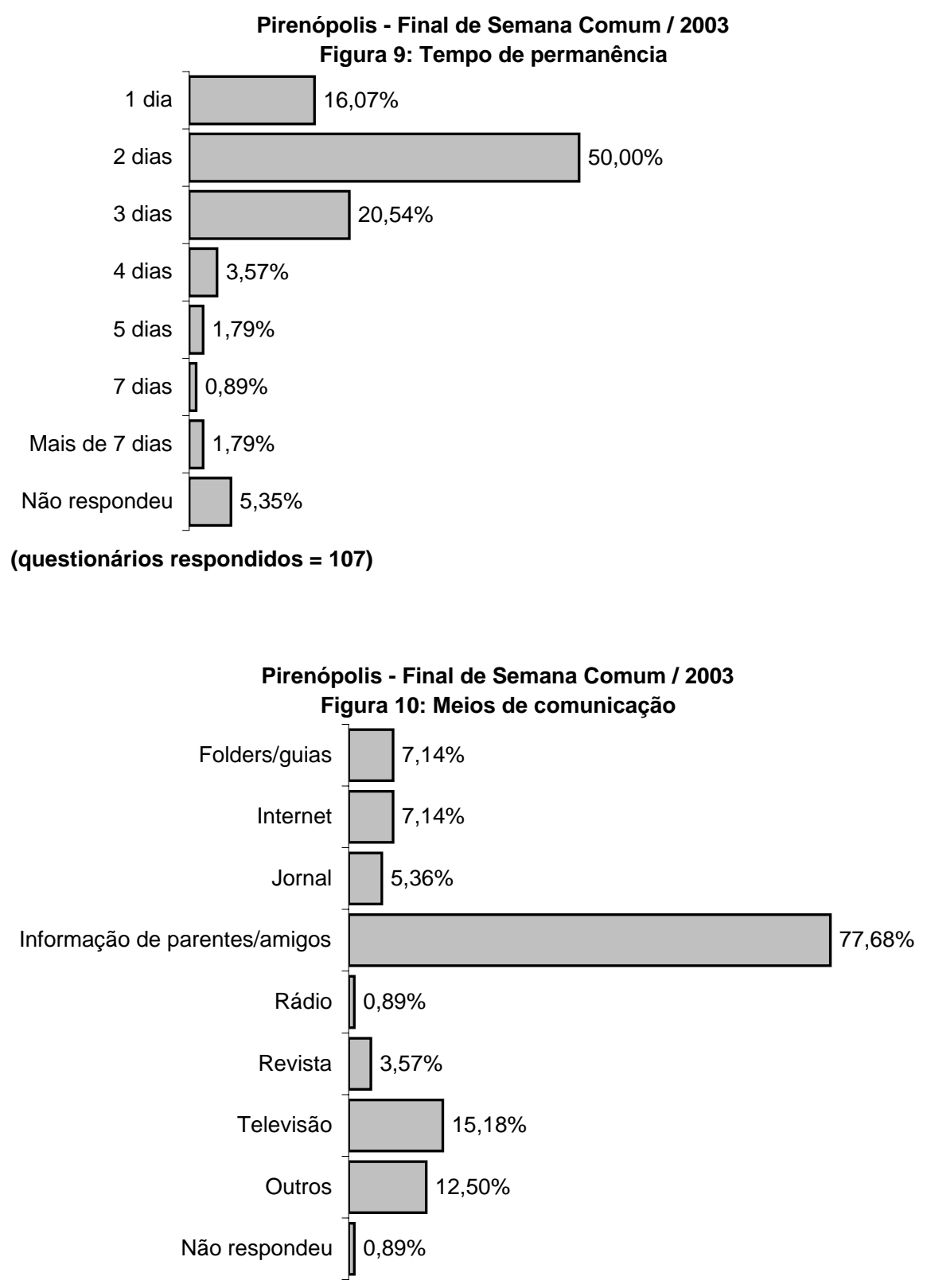

Fonte: AGETUR (questionários respondidos = 111)

Obs.: Esta questão permitia ao entrevistado marcar mais de uma resposta

Pirenópolis - Final de Semana Comum / 2003

Figura 11: Escolaridade

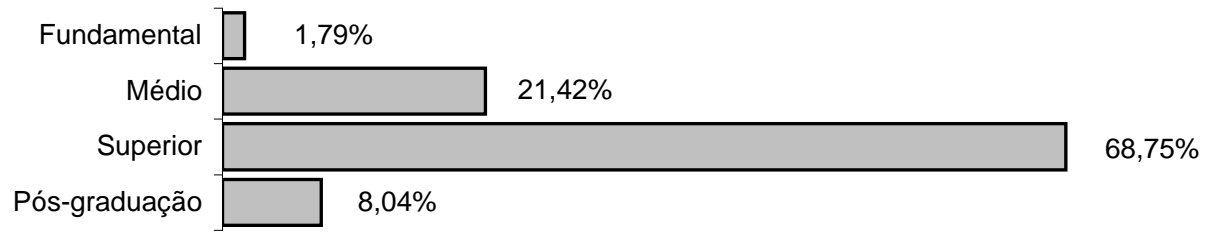

(questionários respondidos $=103$ ) 


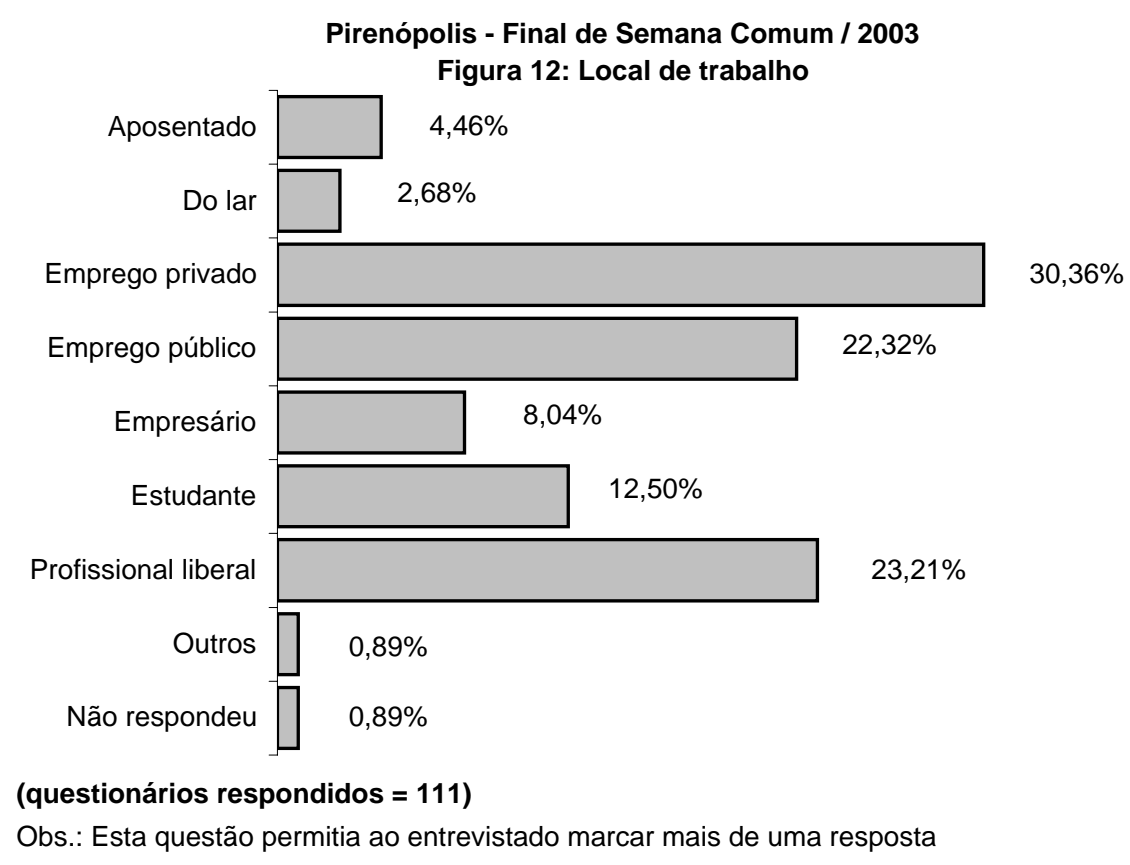

Pirenópolis - Final de Semana Comum / 2003 Figura 13: Renda pessoal

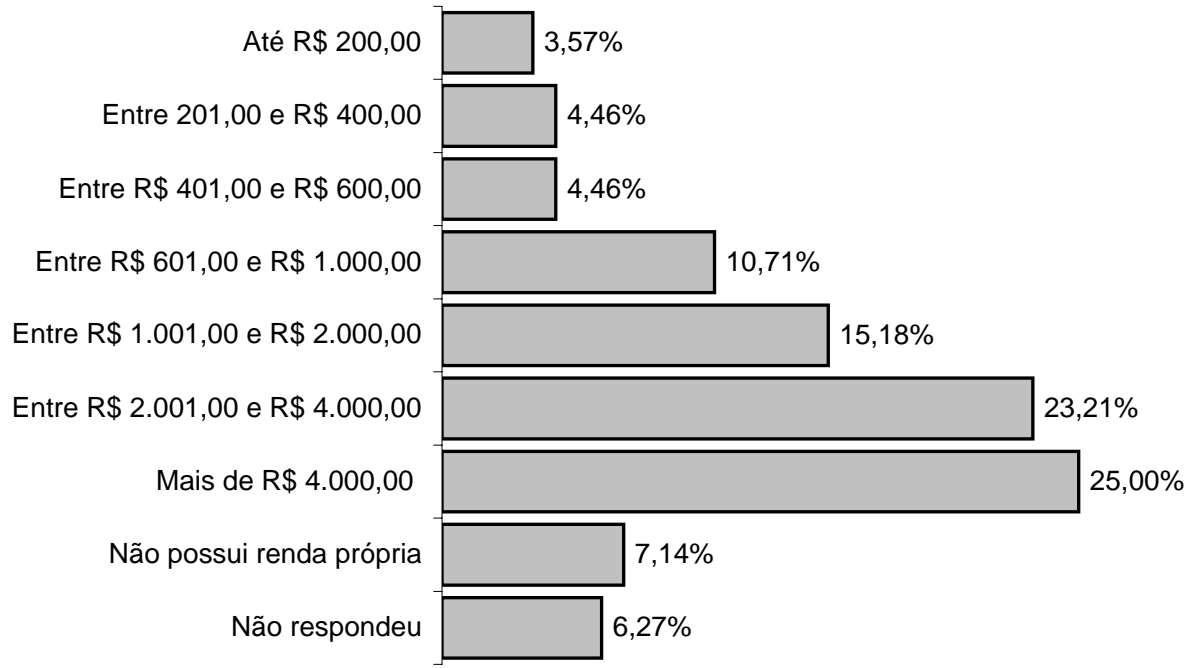

(questionários respondidos $=105$ ) 
Pirenópolis - Final de Semana Comum / 2003

Figura 14: Atividades durante a visita

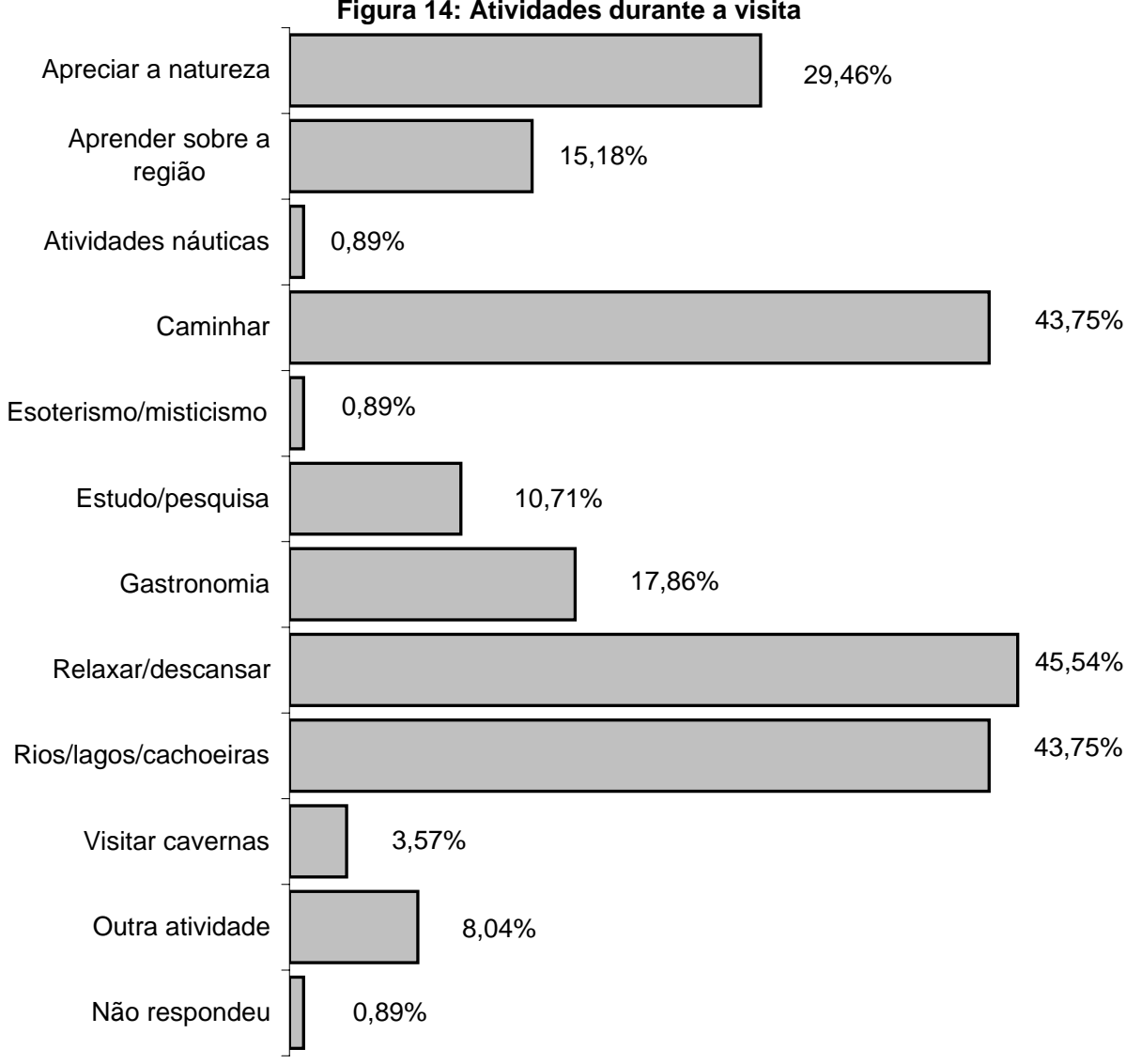

(questionários respondidos $=111$ )

Obs.: Esta questão permitia ao entrevistado marcar mais de uma resposta

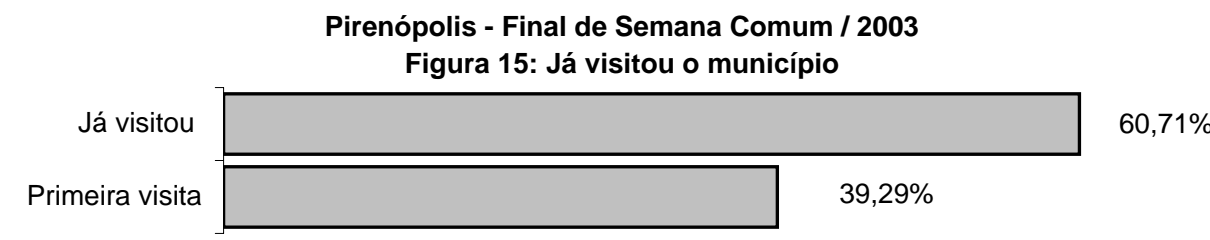

(questionários respondidos $=112$ )

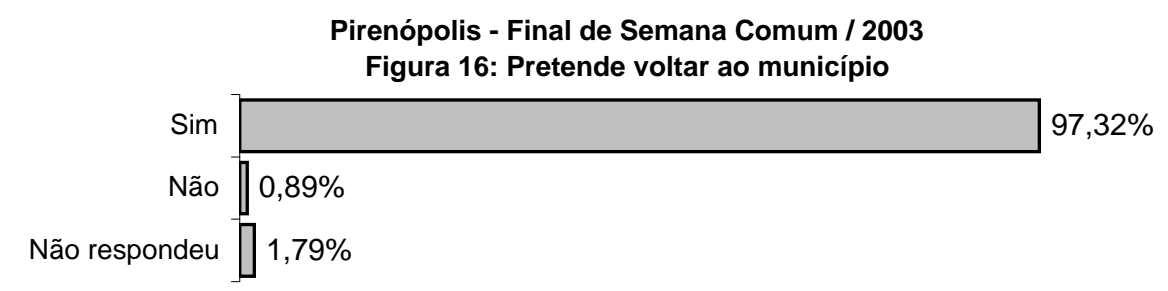

(questionários respondidos $=110$ ) 


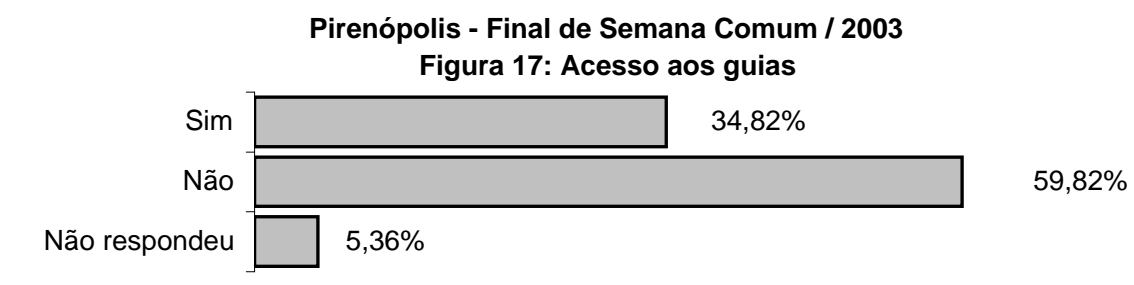

(questionários respondidos $=106$ )

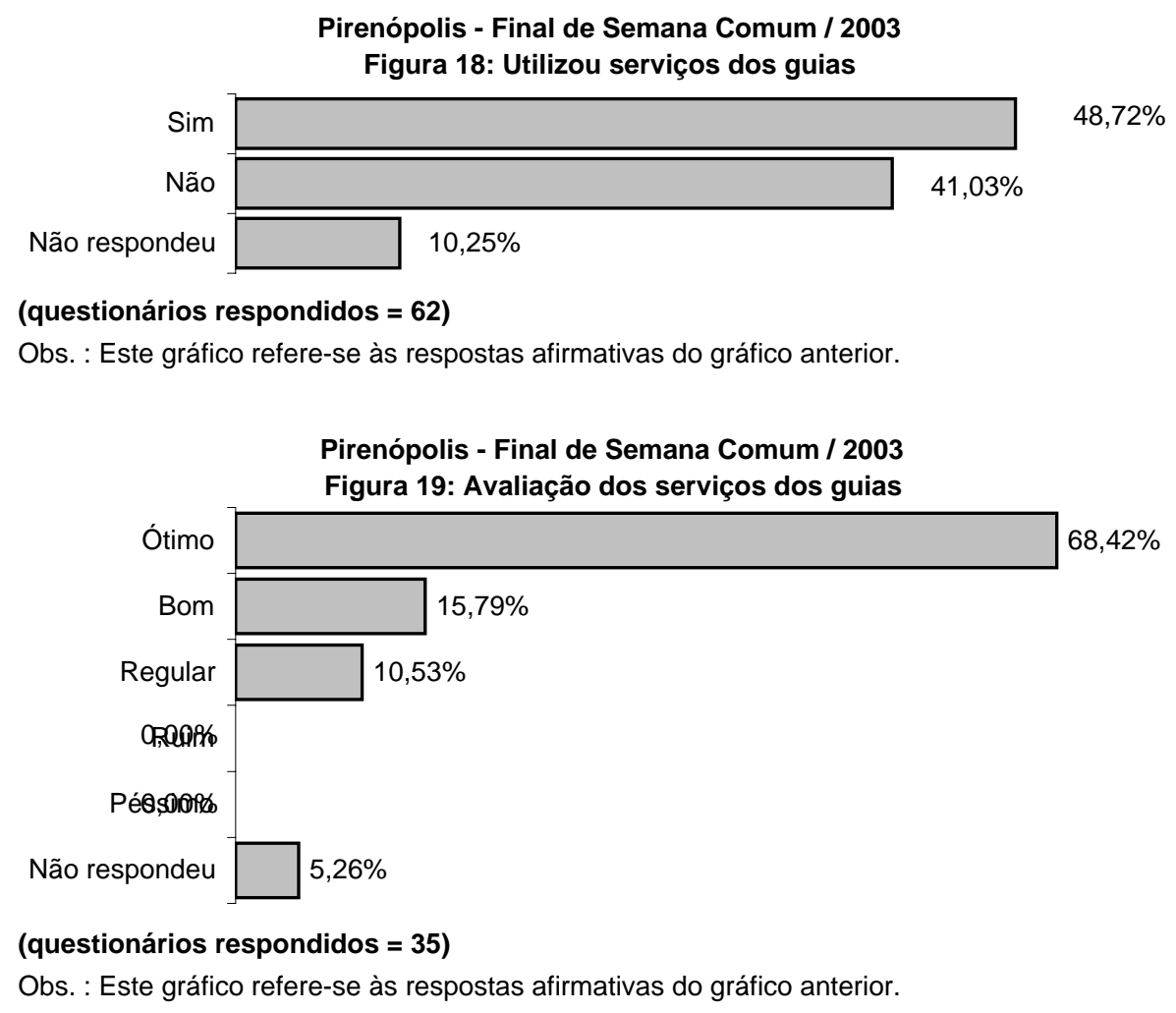

Percepção do Visitante

\section{AVALIACCÃO DA INFRA-ESTRUTURA}

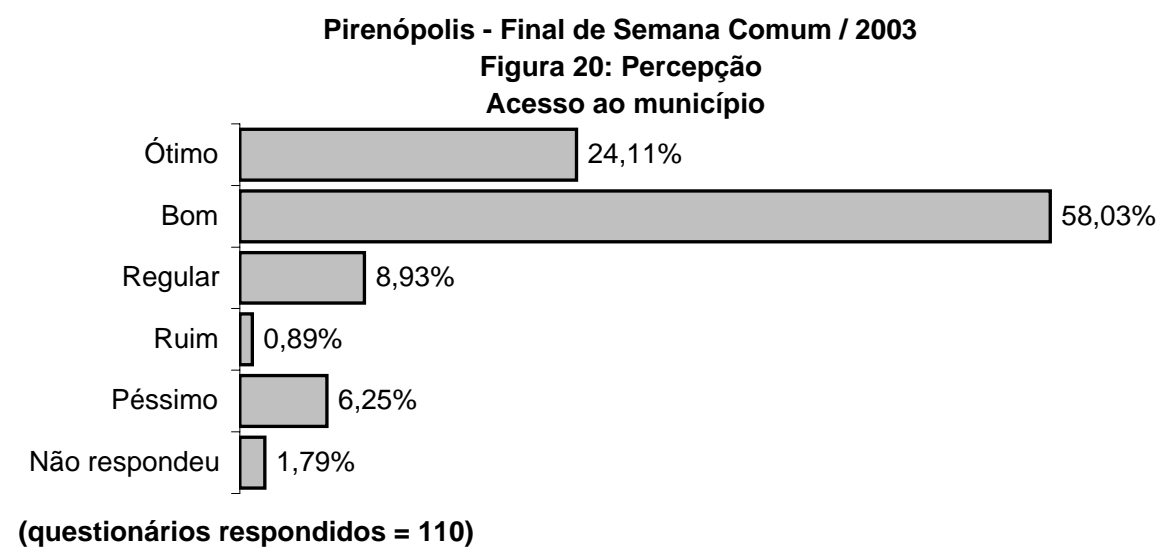




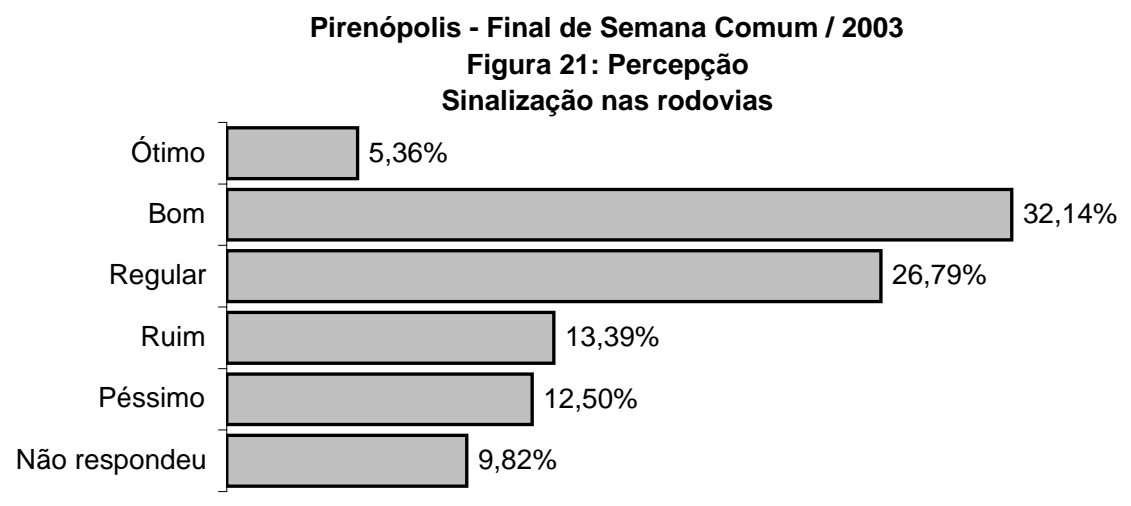

(questionários respondidos $=101$ )

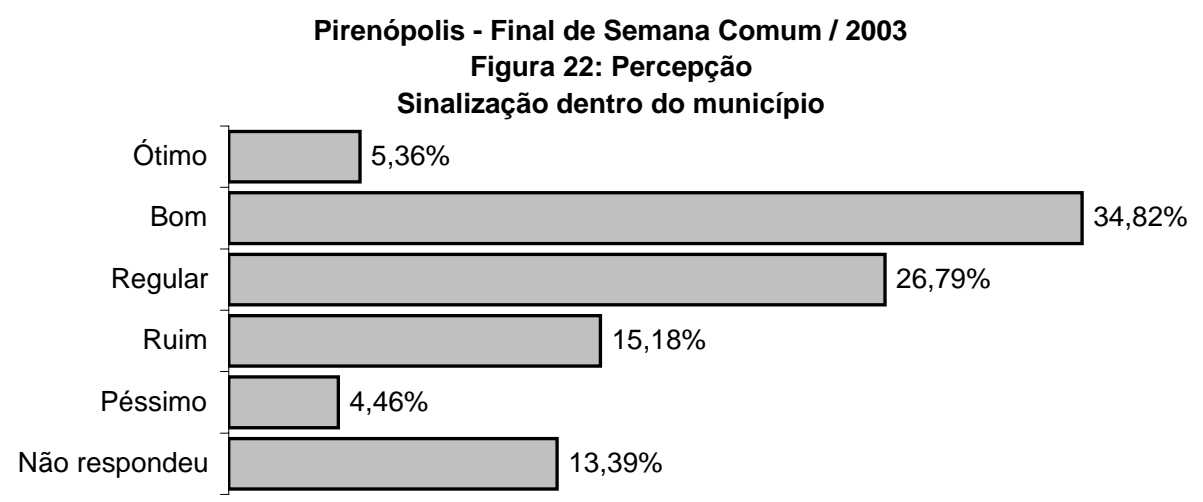

(questionários respondidos = 97)

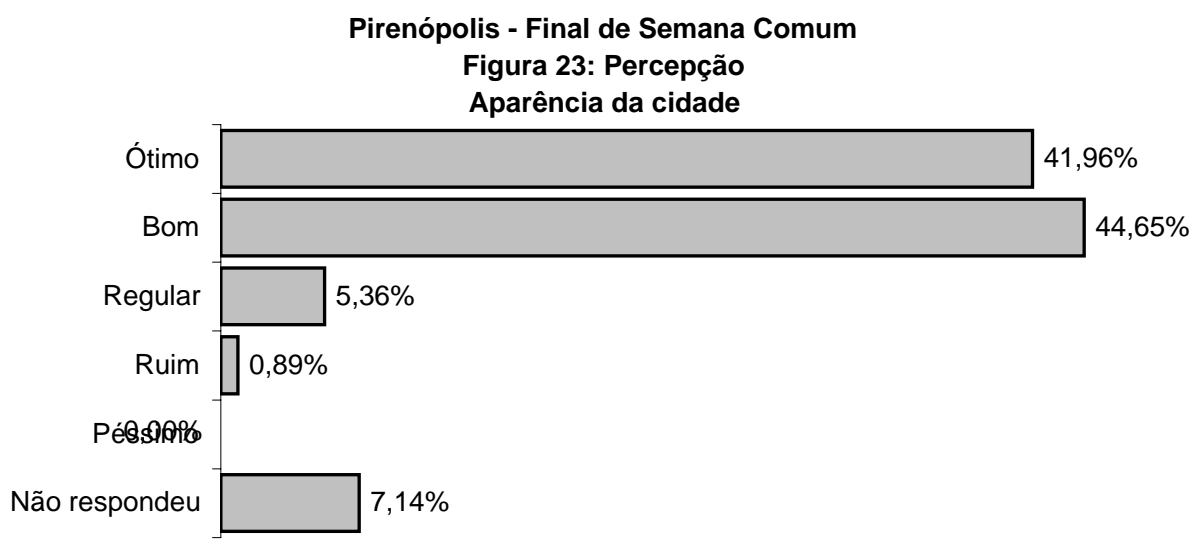

(questionários respondidos $=104$ ) 


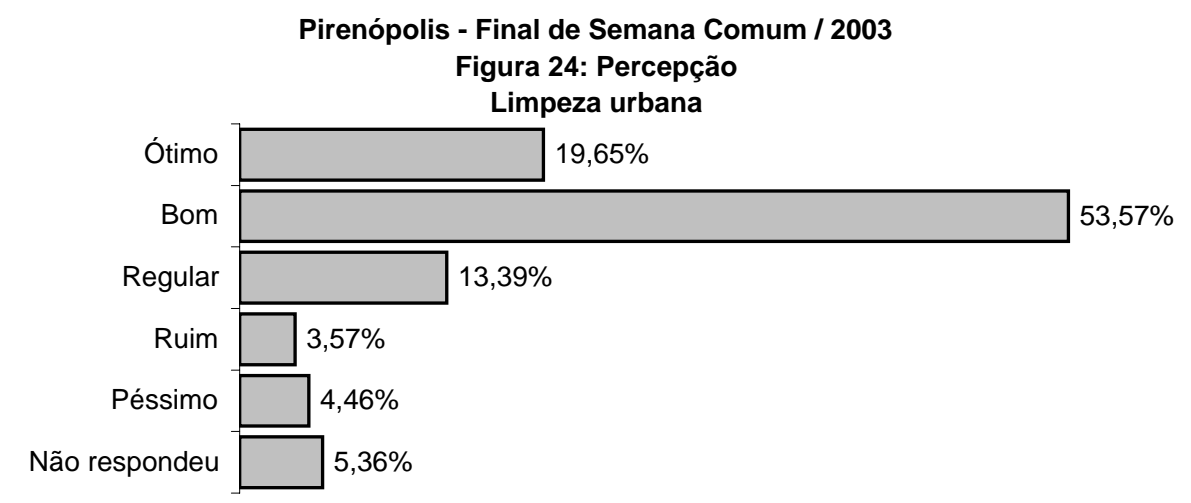

(questionários respondidos $=106$ )

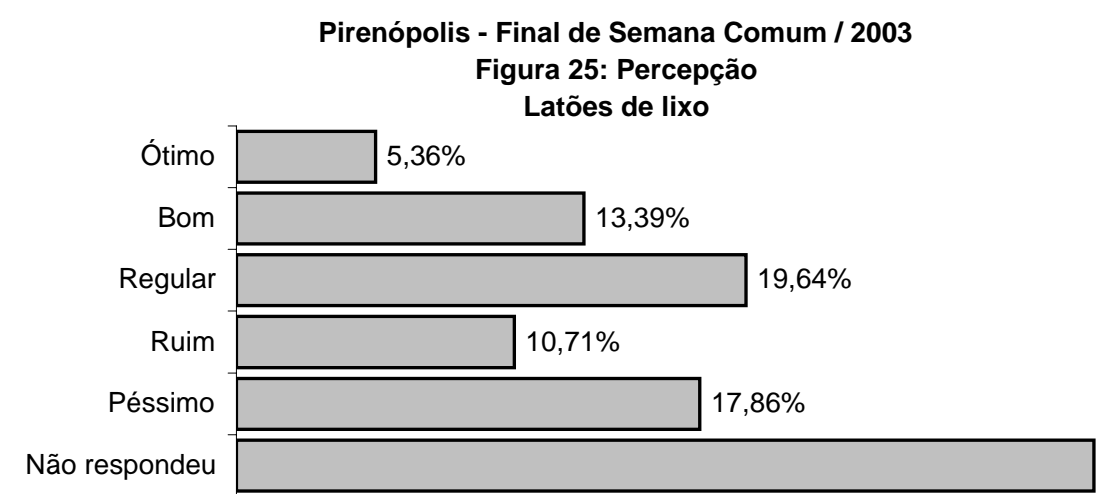

$33,04 \%$

(questionários respondidos $=75$ )

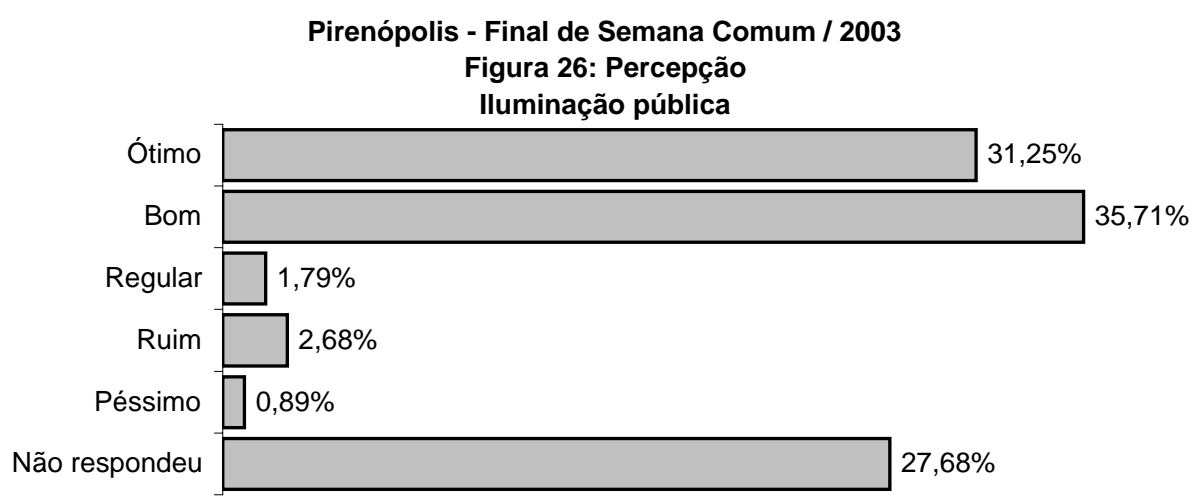

(questionários respondidos $=81$ ) 


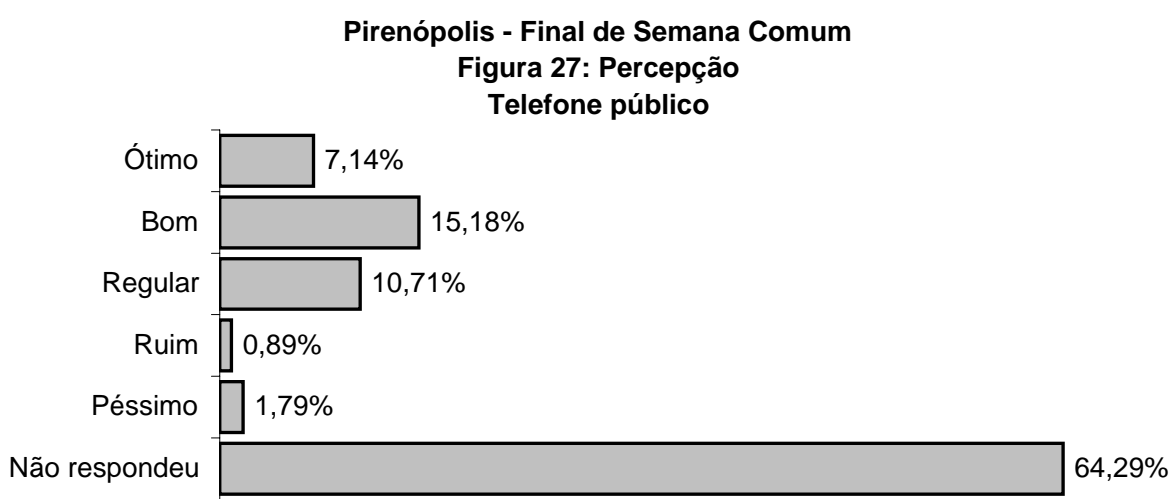

(questionários respondidos $=40$ )

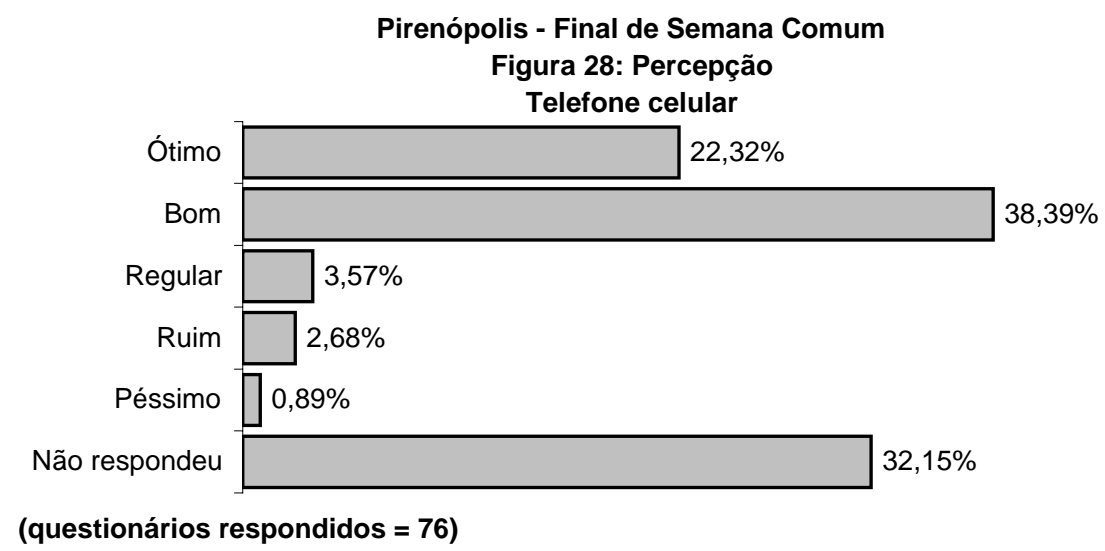

Pirenópolis - Final de Semana Comum / 2003

Figura 29: Percepção

Serviços de transporte de uso público

Ótimo $] 1,79 \%$
Bom $\square 4,46 \%$
Regular $\left.\begin{array}{r}1,79 \% \\ \text { Ruim } \\ \text { Péssimo }\end{array}\right] 1,79 \%$
$1,79 \%$

Não respondeu

$88,38 \%$

(questionários respondidos $=13$ ) 


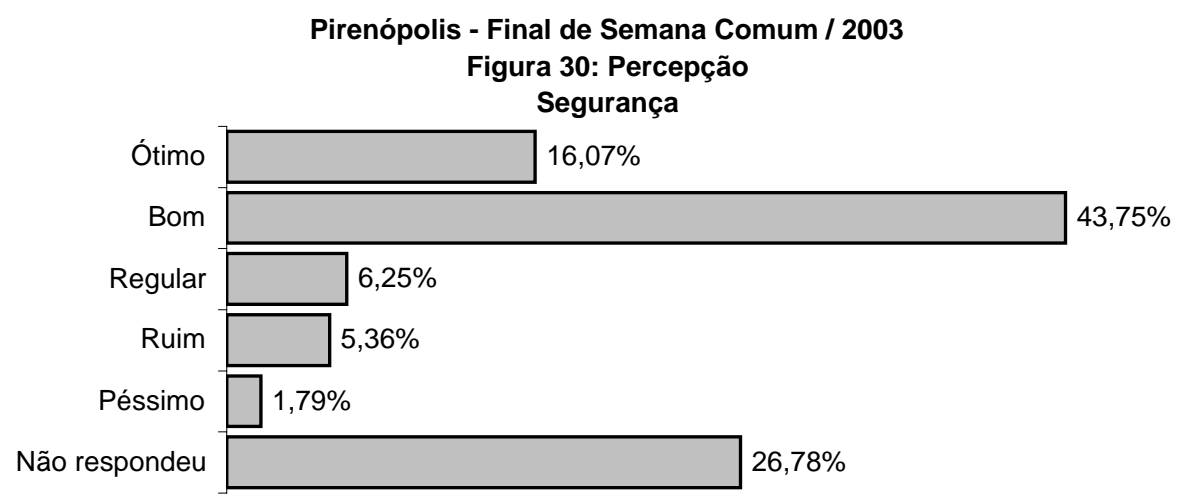

(questionários respondidos $=\mathbf{2 6}$ )

Pirenópolis - Final de Semana Comum / 2003

Figura 31: Percepção

Serviços médicos / hospitalares

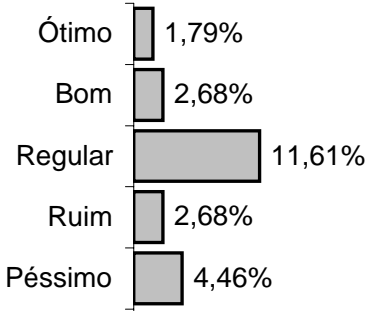

Não respondeu

$76,78 \%$

(questionários respondidos $=26$ )

\section{AVALIAÇÃO DOS ATRATIVOS}

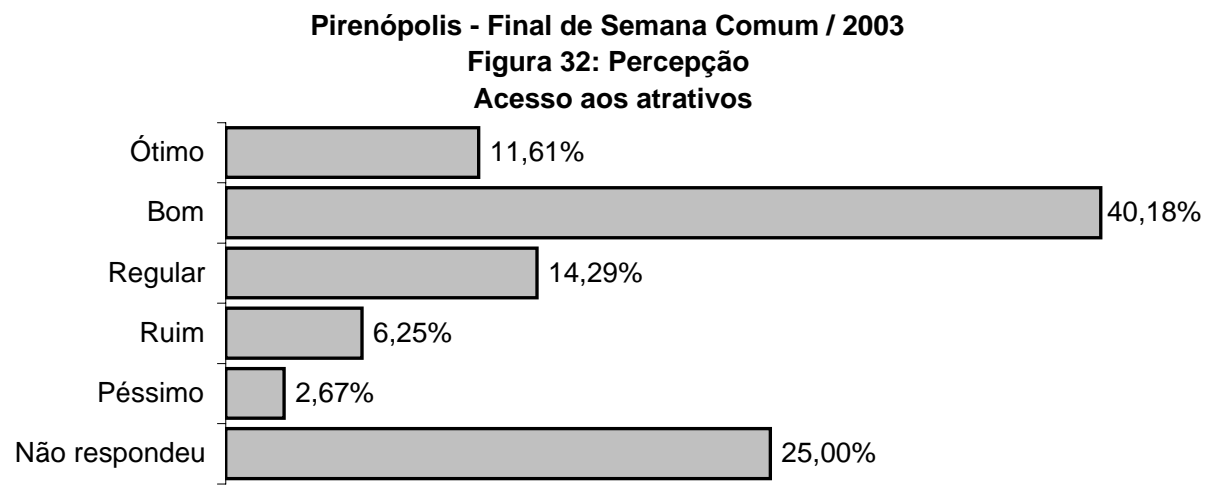

(questionários respondidos $=84$ ) 


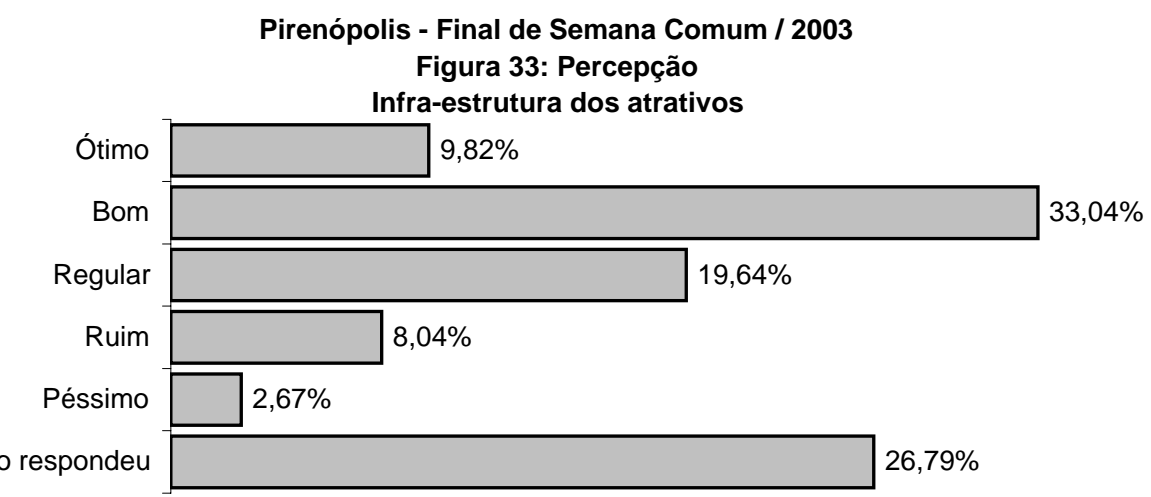

(questionários respondidos $=\mathbf{8 2}$ )

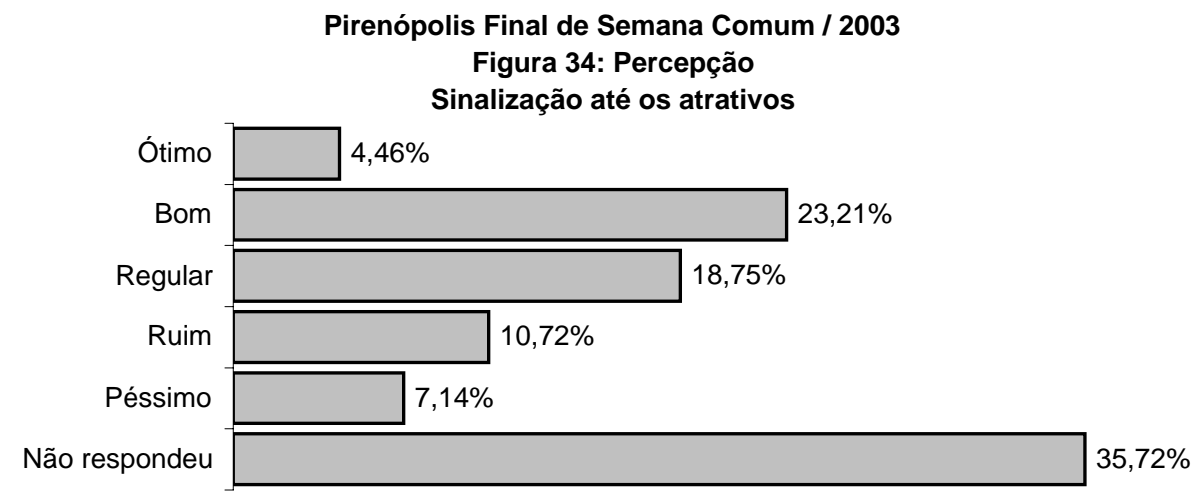

(questionários respondidos $=72$ )

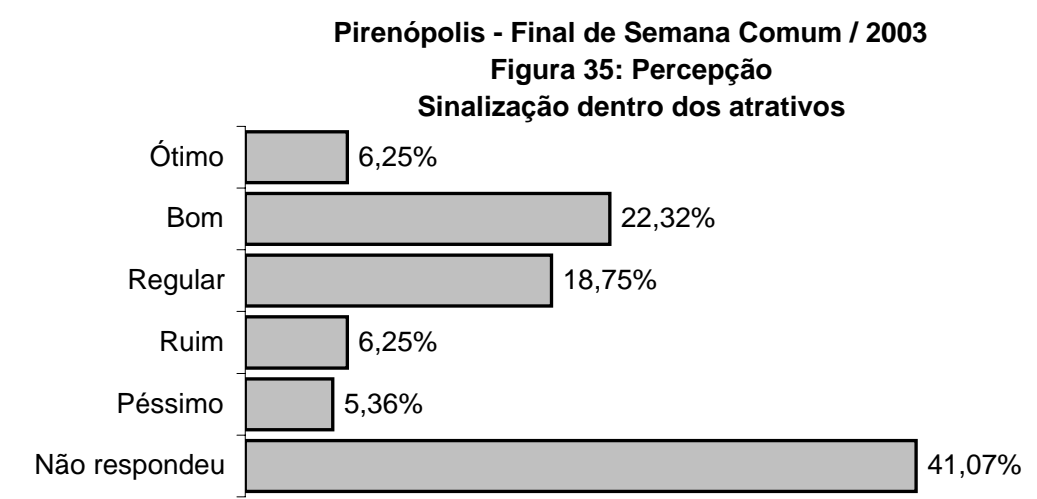

(questionários respondidos $=66$ ) 


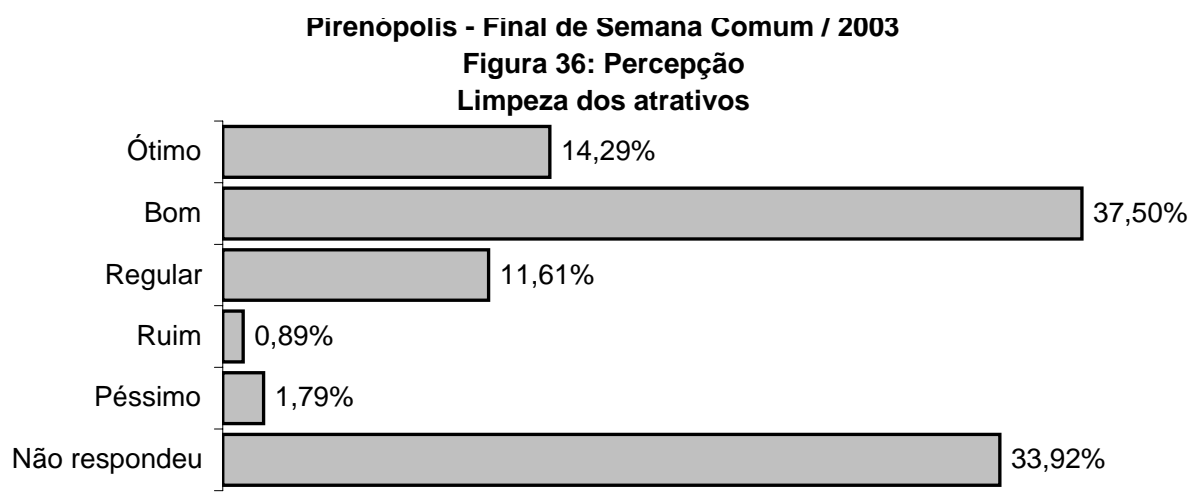

(questionários respondidos $=74$ )

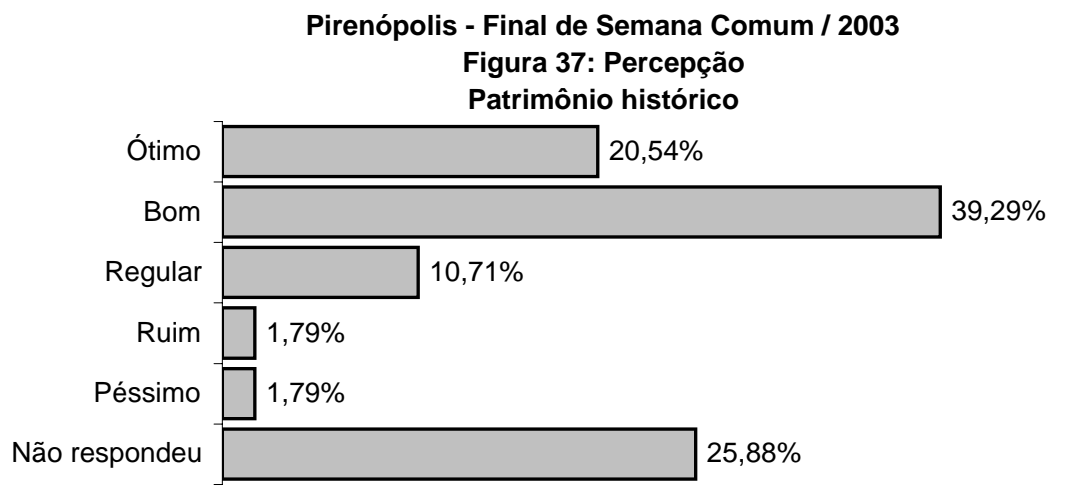

(questionários respondidos $=83$ )

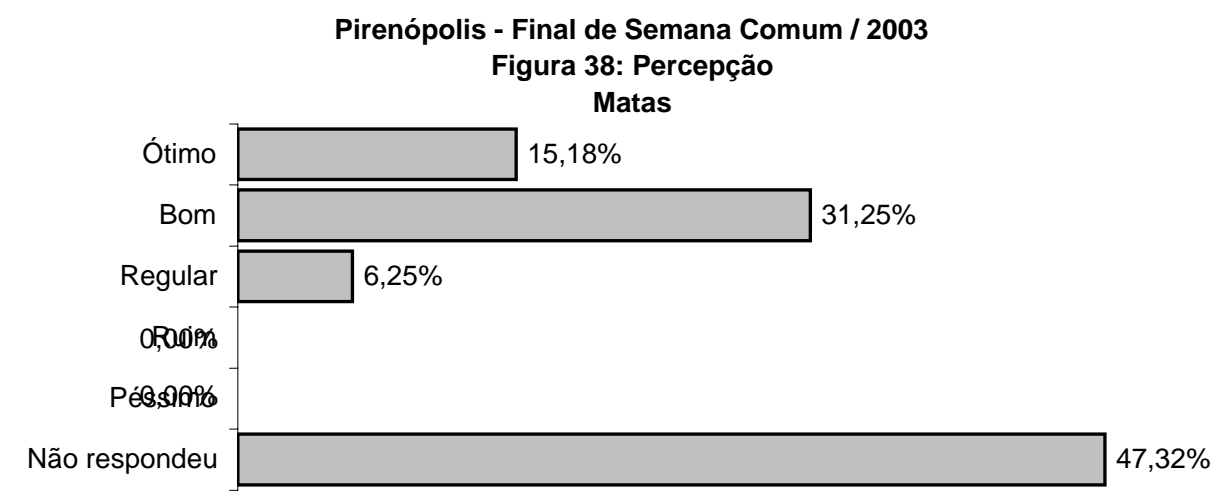

(questionários respondidos $=59$ ) 


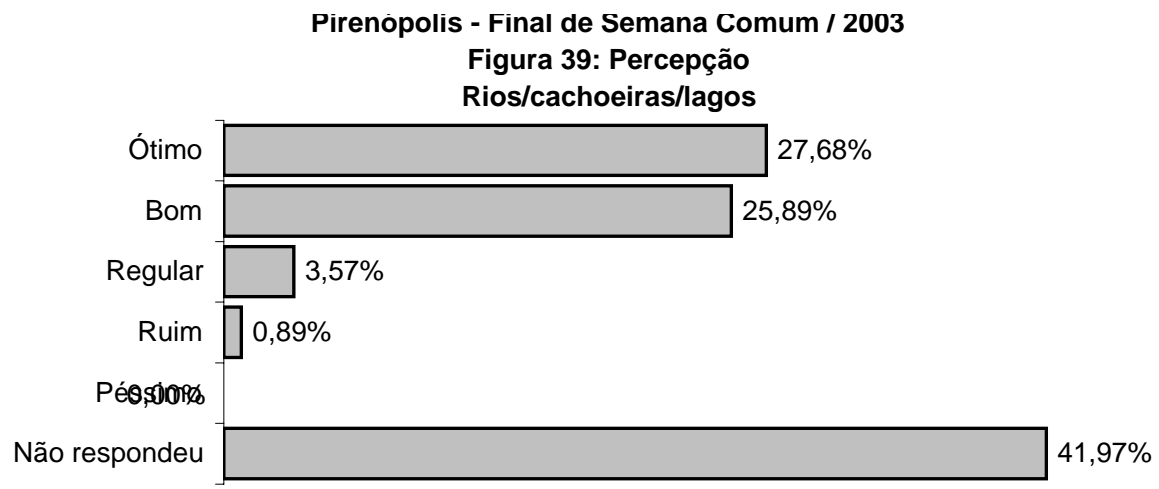

(questionários respondidos $=65$ )

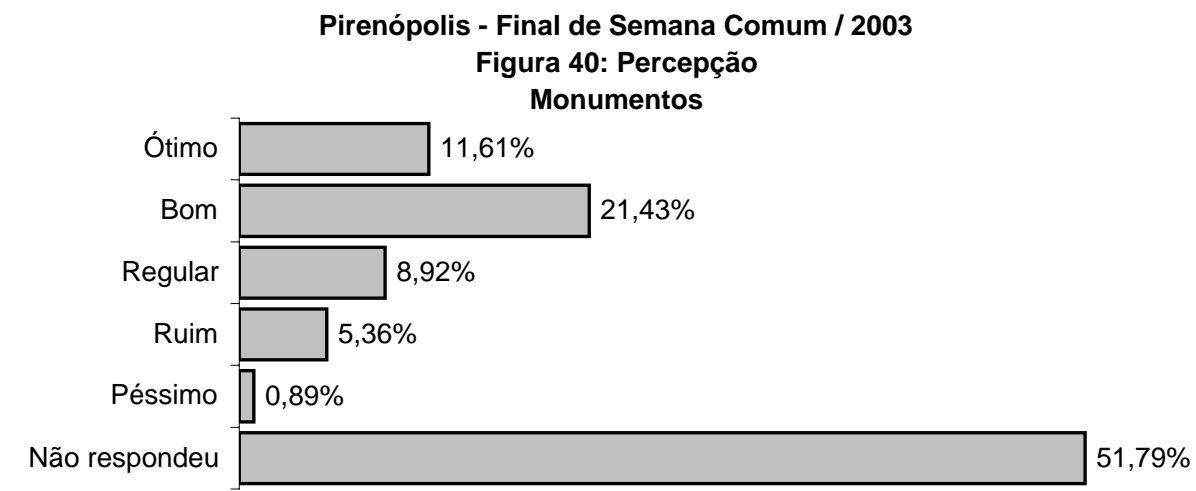

(questionários respondidos $=54$ )

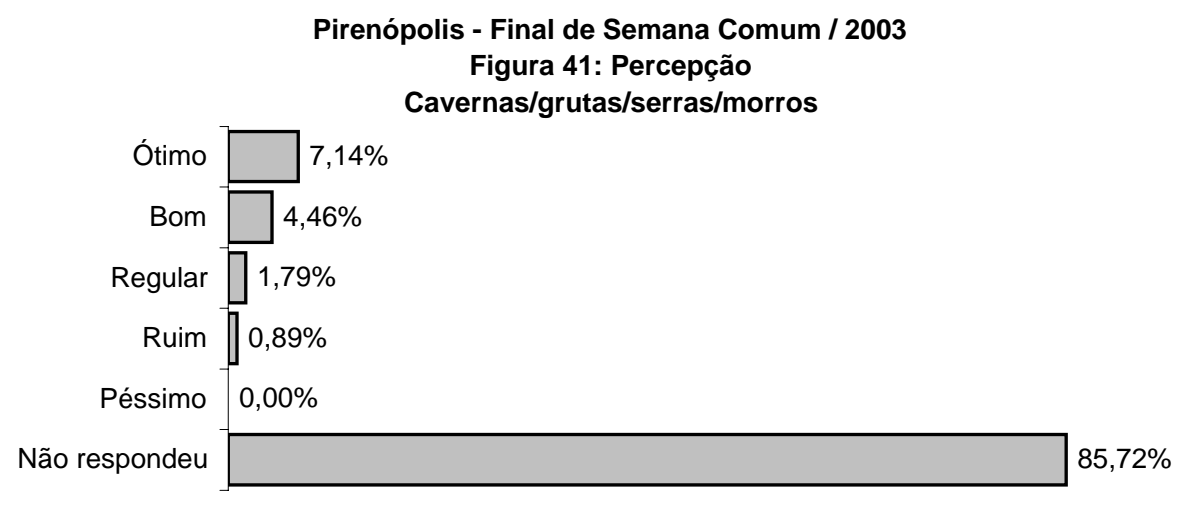

(questionários respondidos $=16$ ) 


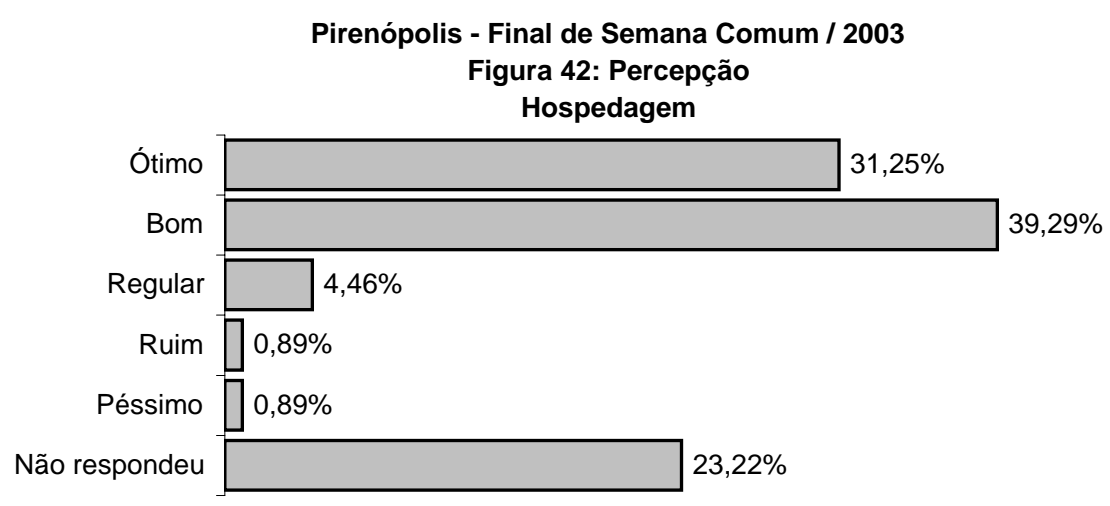

(questionários respondidos $=86$ )

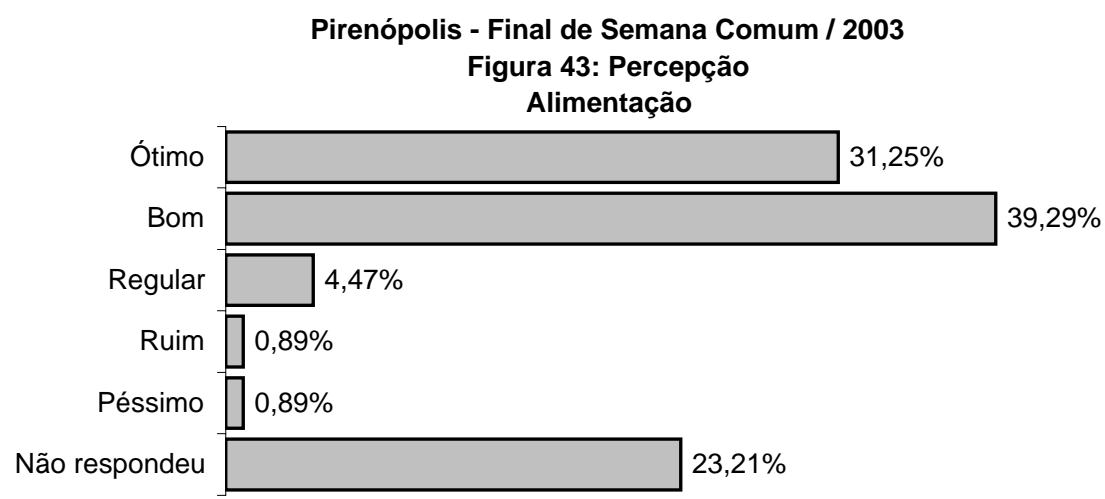

(questionários respondidos = 86)

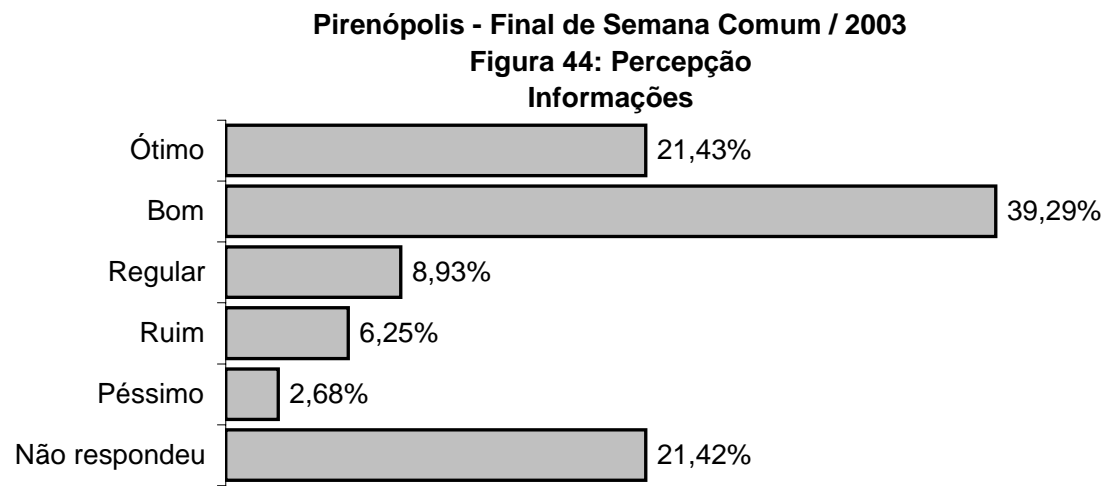

(questionários respondidos $=88$ ) 


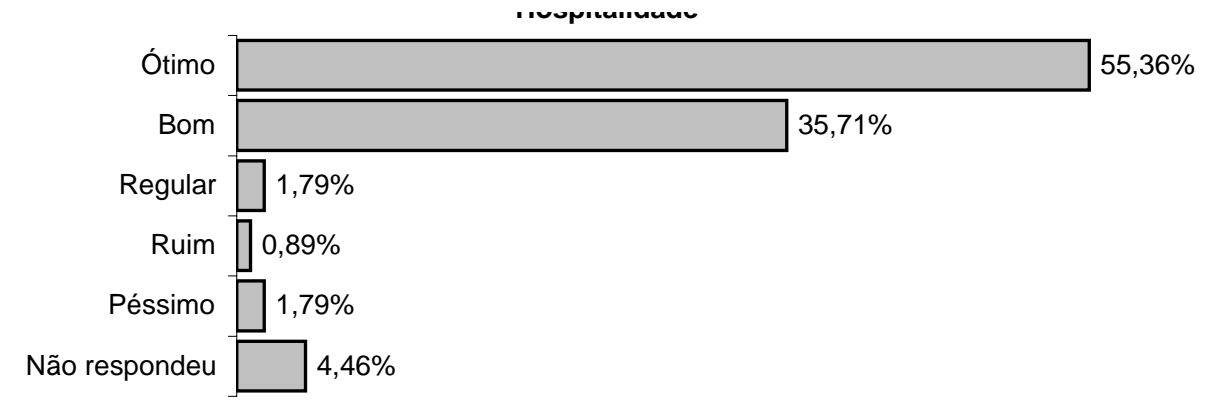

(questionários respondidos = 107)

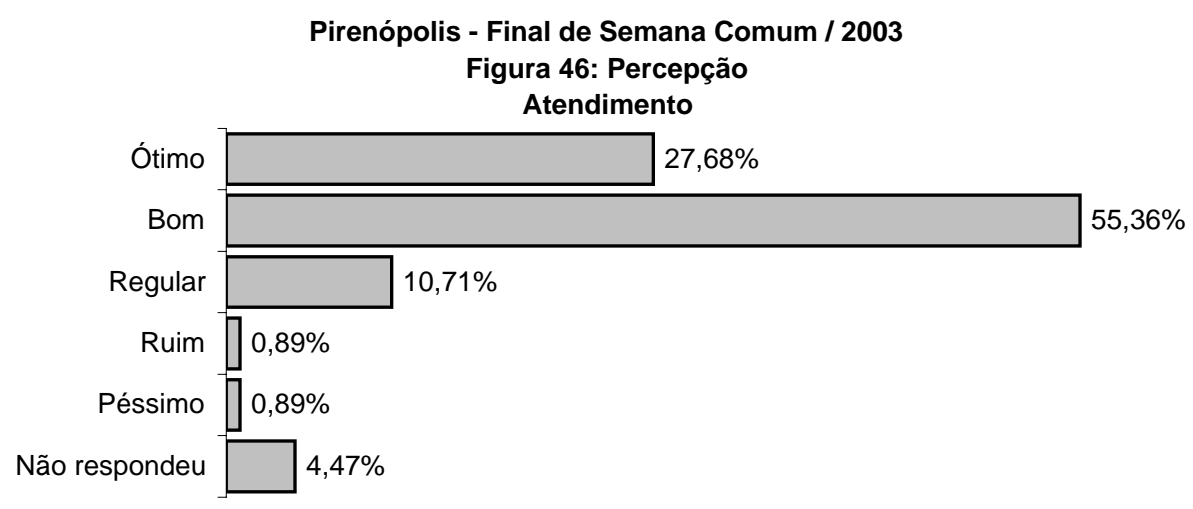

(questionários respondidos = 107)

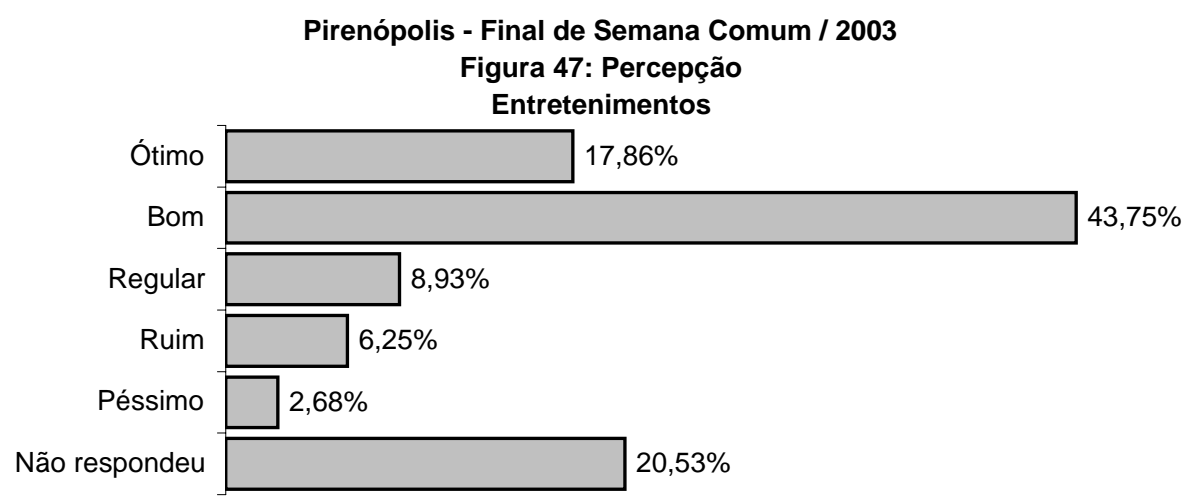

(questionários respondidos $=89$ )

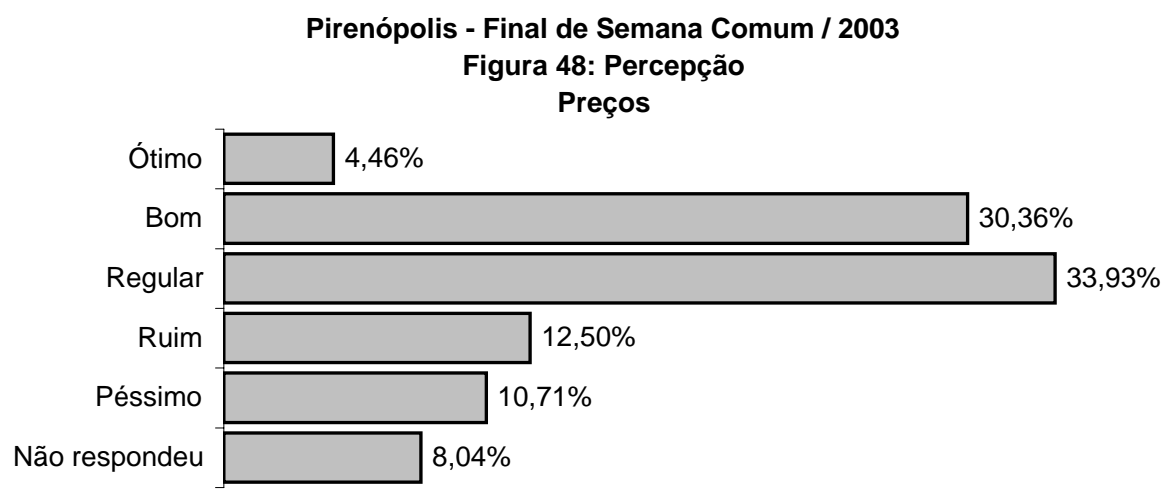

(questionários respondidos = 103) 


\section{Férias de Julho - Perfil do Visitante}

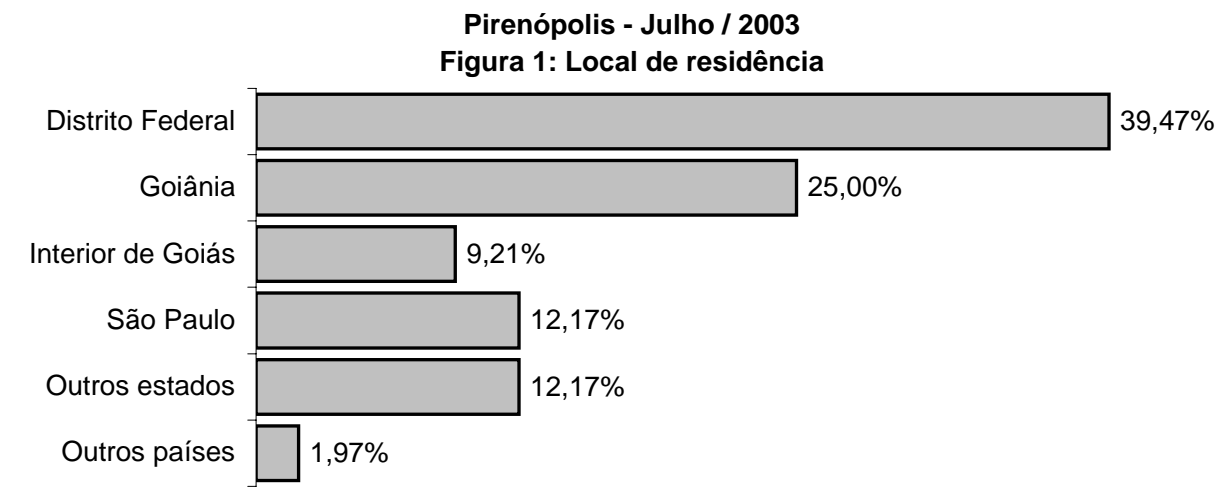

(quesionários respondidos $=304$ )

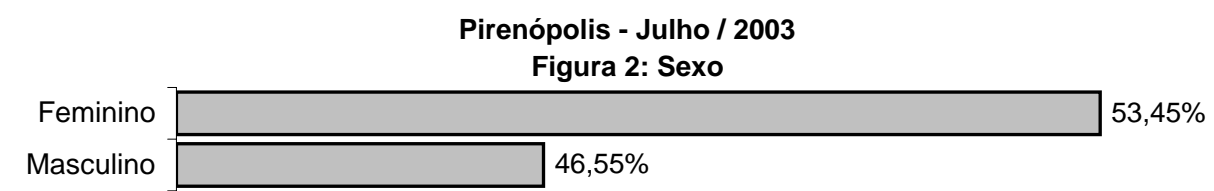

(quesionários respondidos $=304$ )

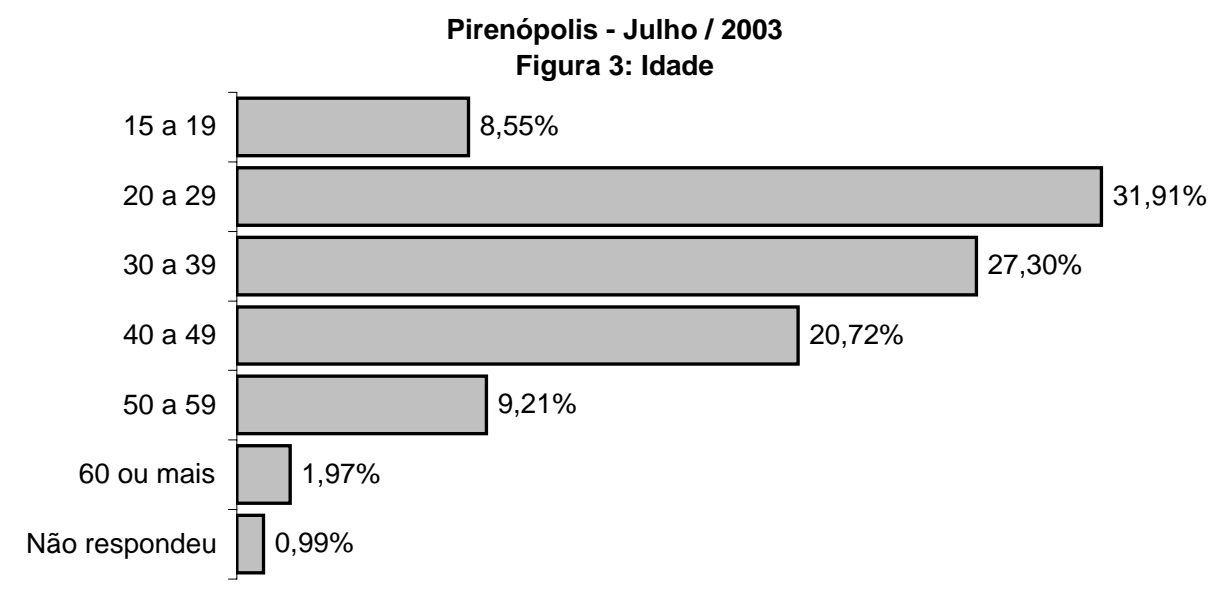

(quesionários respondidos $\mathbf{3 0 1}$ )

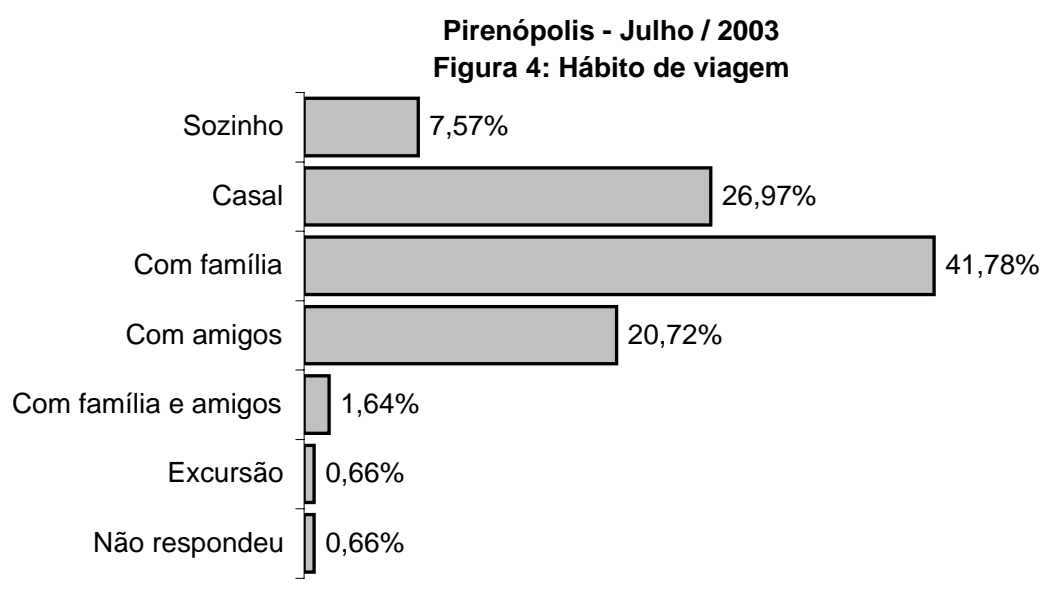

(quesionários respondidos $=302$ ) 


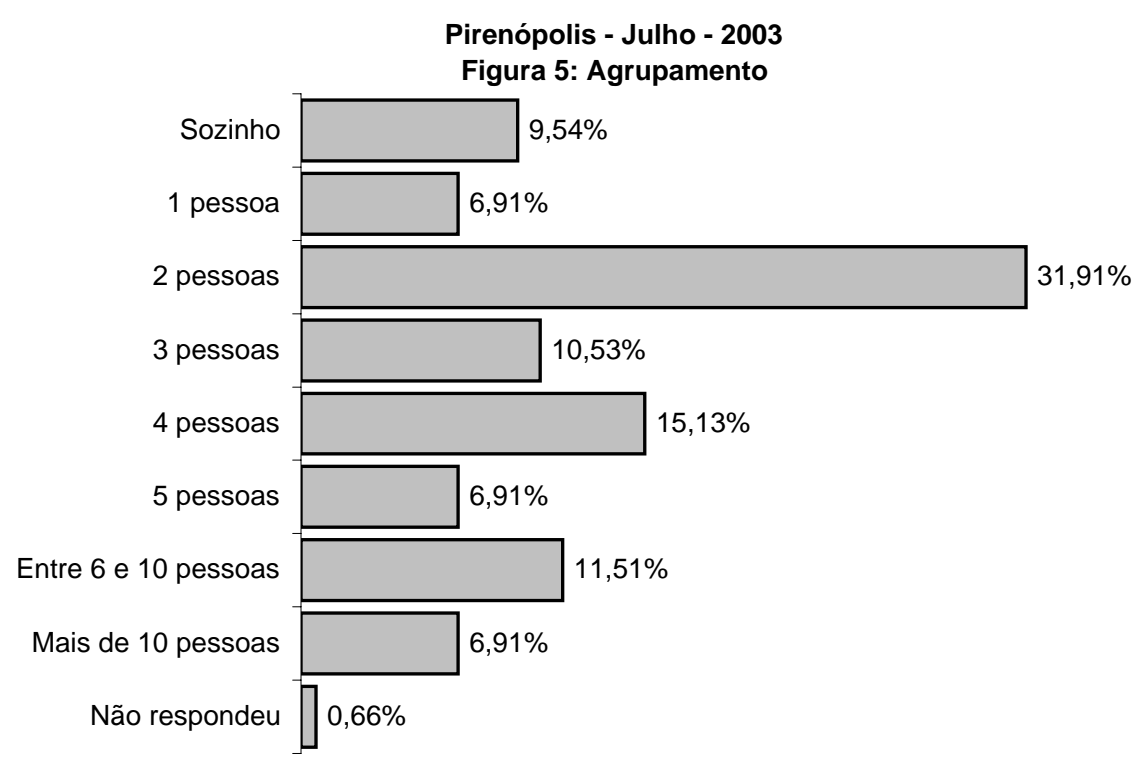

(quesionários respondidos $=302$ )

Pirenópolis - Julho / 2003

Figura 6: Meio de transporte

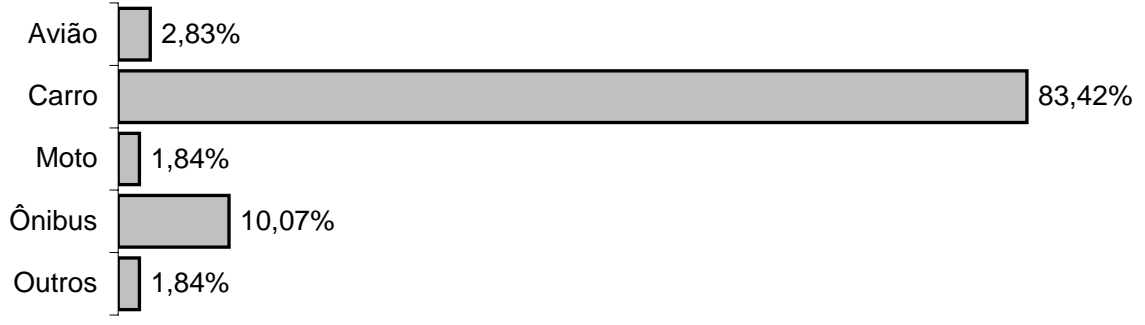

(quesionários respondidos $\mathbf{=}$ 304)

Obs: Essa questão permitia ao entrevistado marcar mais de uma resposta

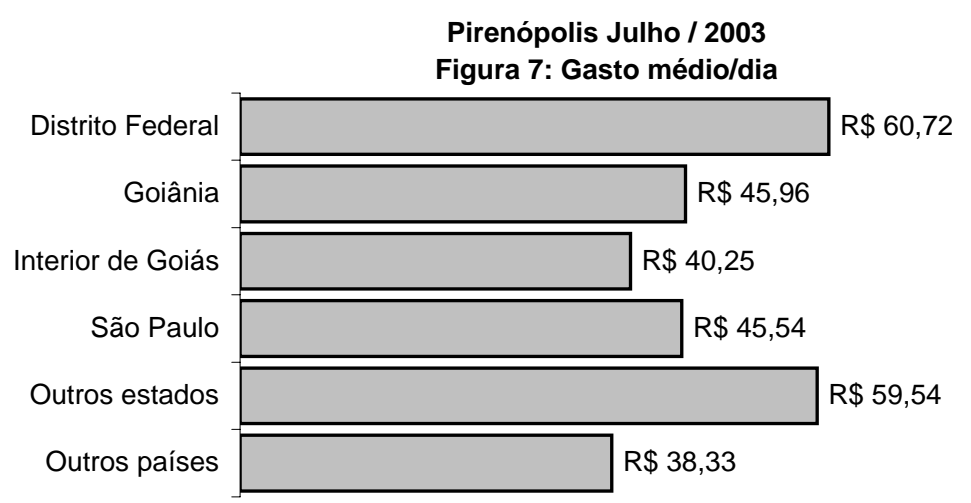

(quesionários respondidos $\mathbf{2} \mathbf{2 4 0}$ ) 
Pirenópolis - Julho / 2003

Figura 8: Local de hospedagem

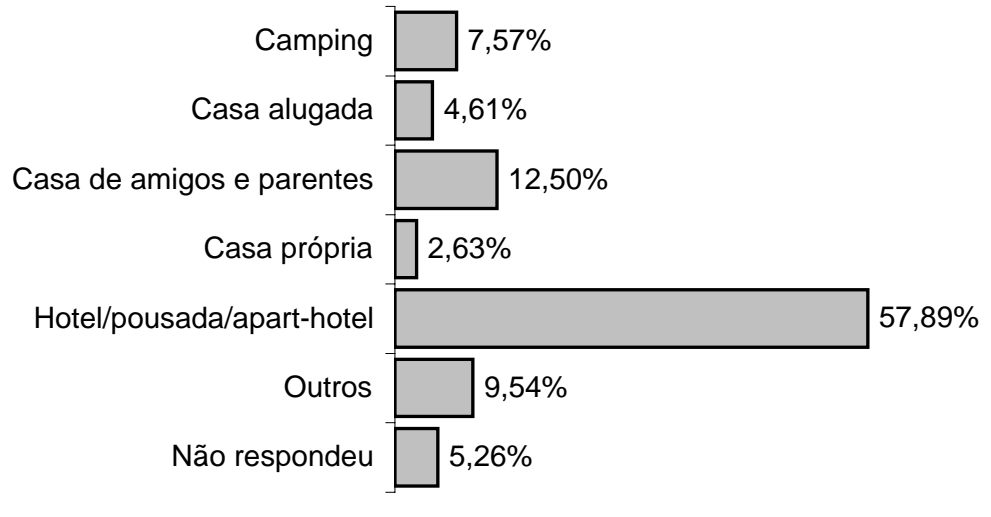

(quesionários respondidos $\mathbf{2} \mathbf{2 8 8}$ )

Pirenópolis - Julho / 2003

Figura 9: Motivo da viagem

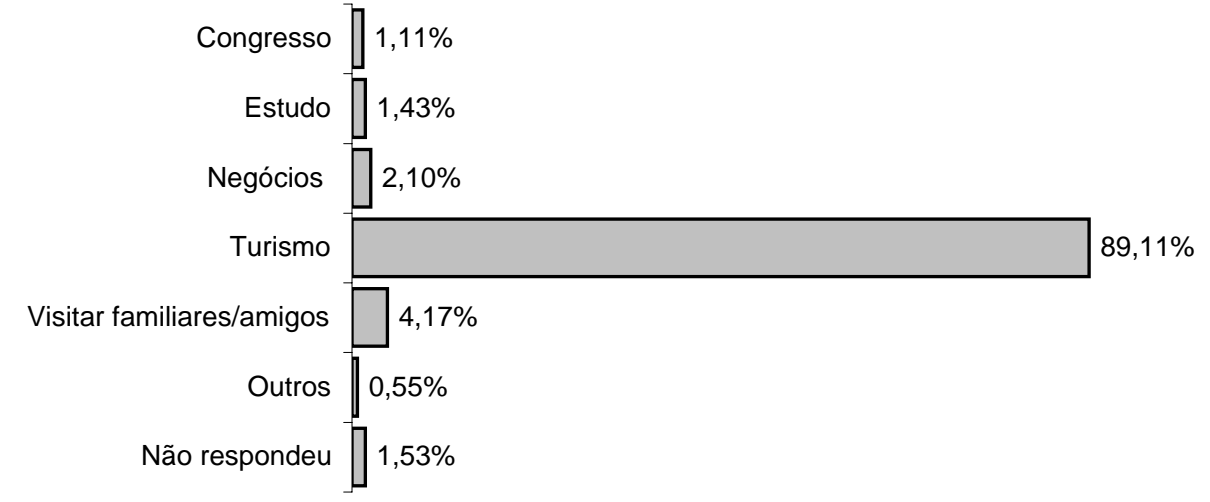

(quesionários respondidos $\mathbf{2 9 9}$ )

Obs: Essa questão permitia ao entrevistado marcar mais de uma resposta

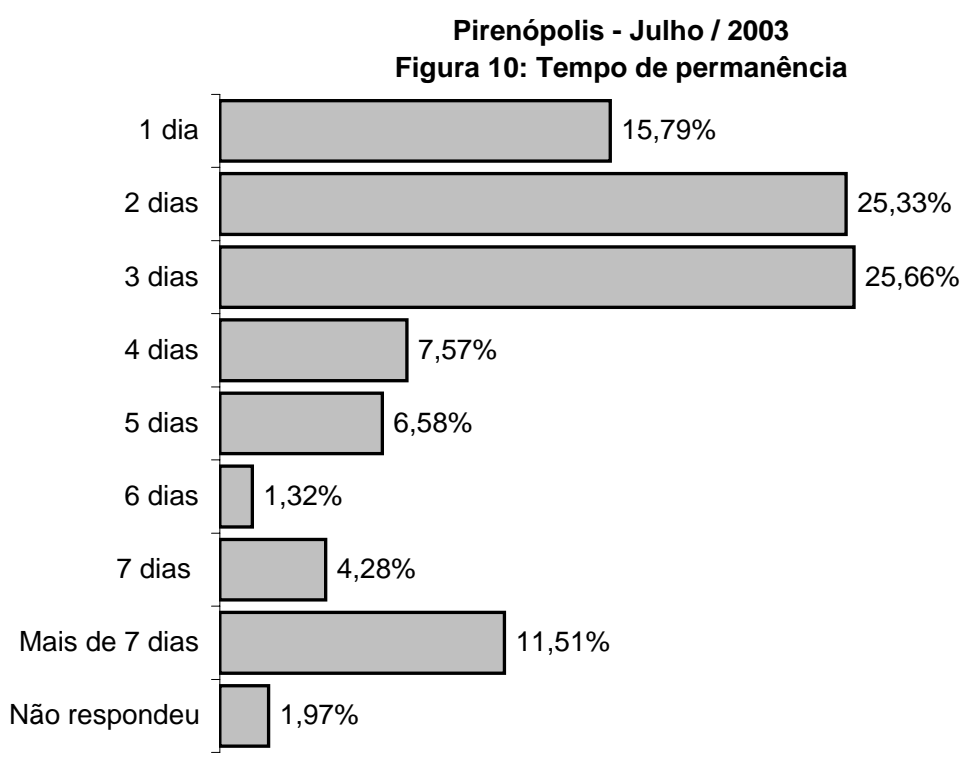

(quesionários respondidos $=298$ ) 
Pirenópolis - Julho / 2003

Figura 11: Meios de comunicação

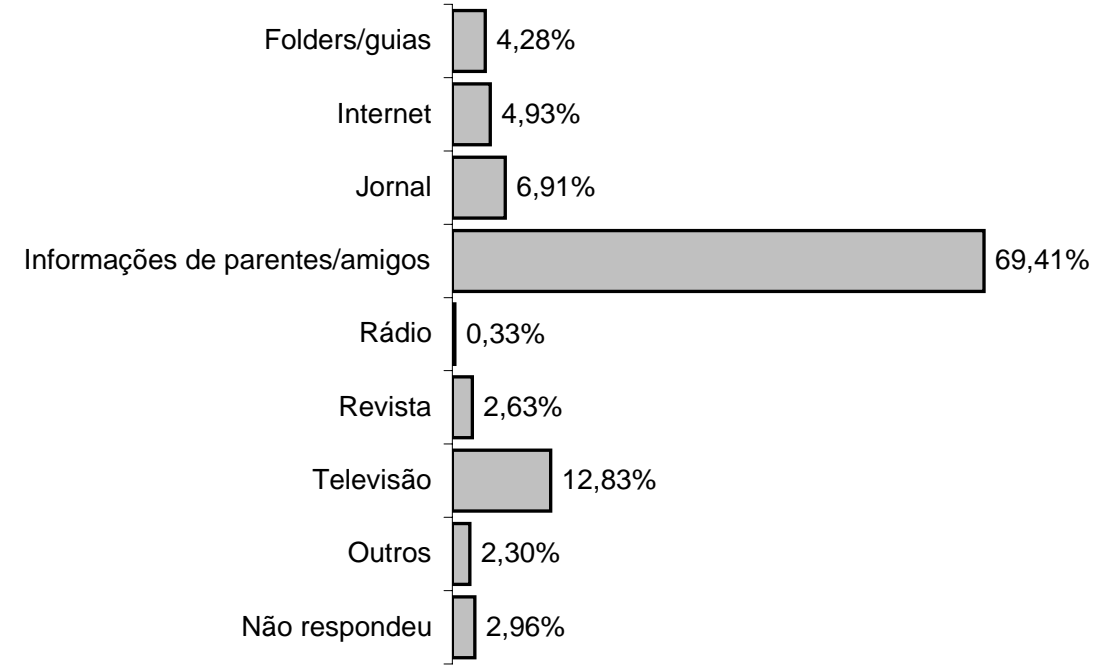

(quesionários respondidos $\mathbf{2}$ 295)

Obs: Essa questão permitia ao entrevistado marcar mais de uma resposta

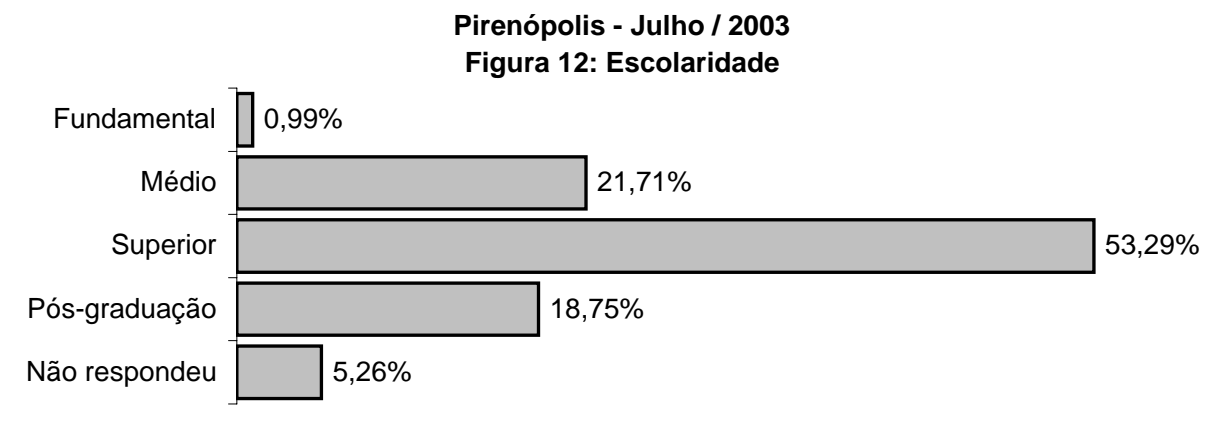

(quesionários respondidos $\mathbf{2}$ 288)

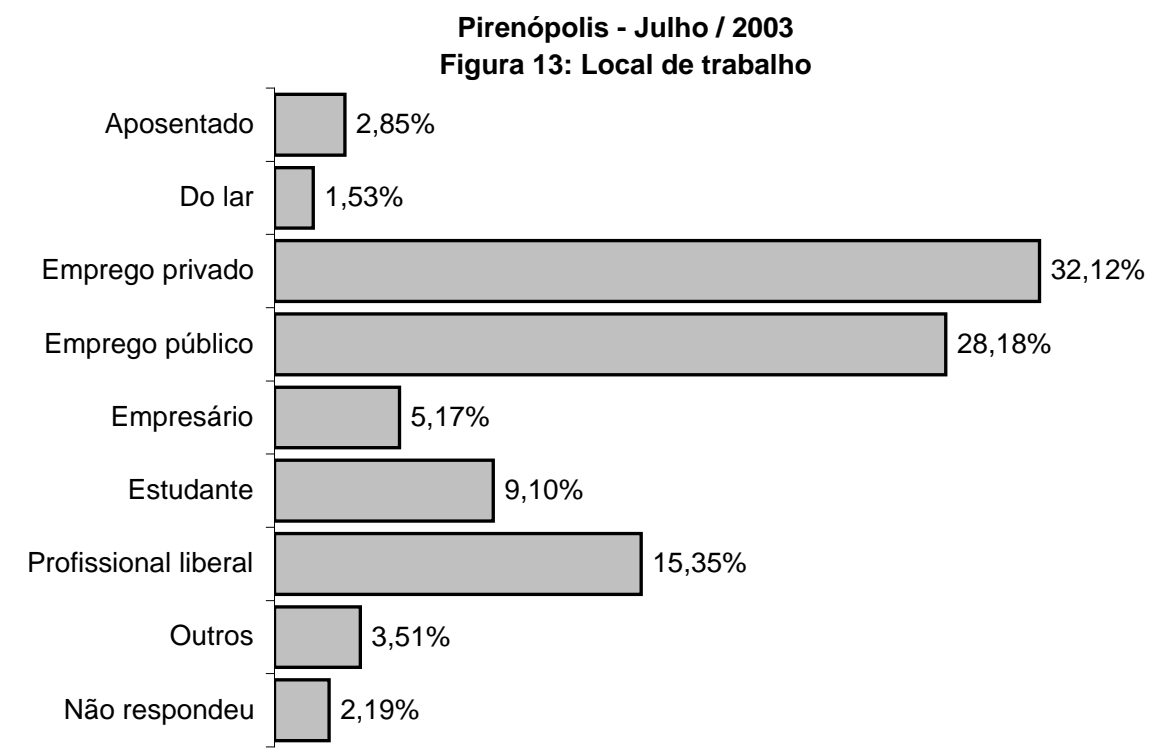

(quesionários respondidos $\mathbf{2 9 7}$ ) 
Pirenópolis - Julho / 2003

Figura 14: Renda pessoal

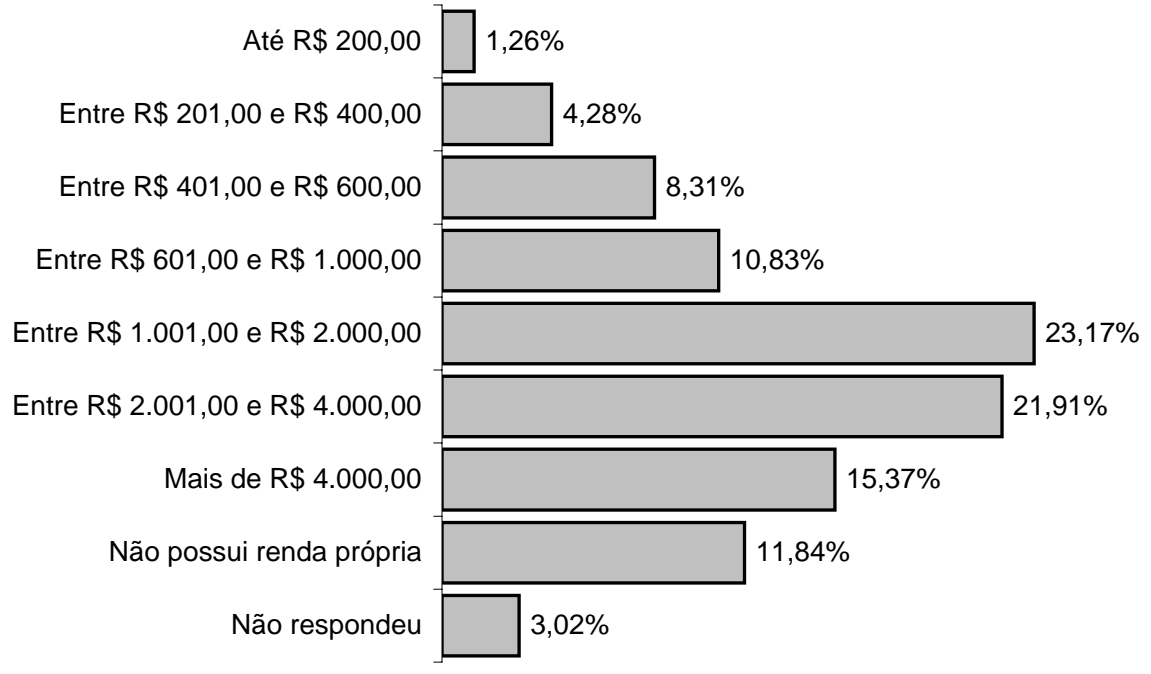

(quesionários respondidos $=\mathbf{2 8 3}$ )

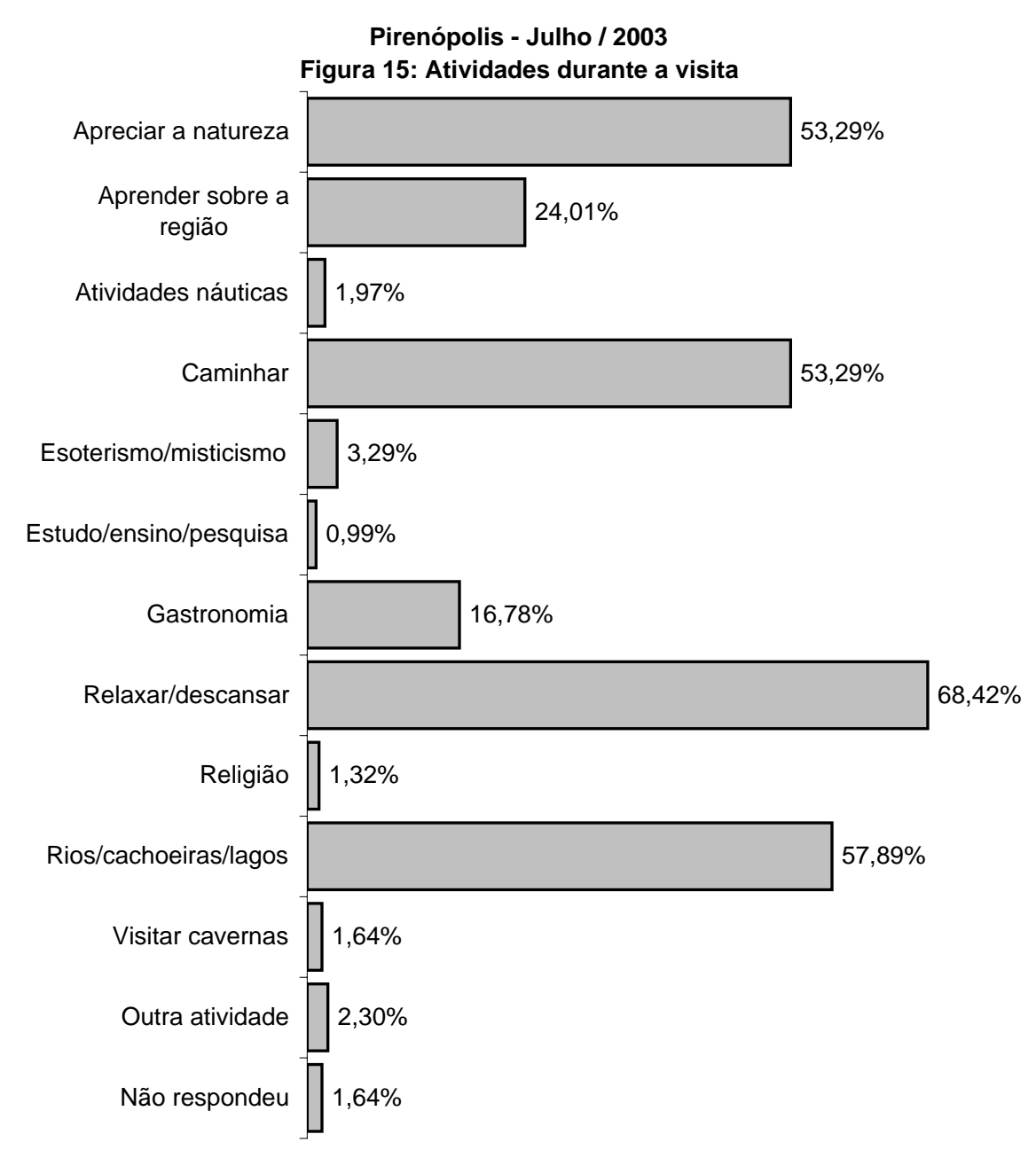

(quesionários respondidos $=$ 299)

Obs: Essa questão permitia ao entrevistado marcar mais de uma resposta 
Pirenópolis - Julho / 2003

Figura 16: Já visitou o município

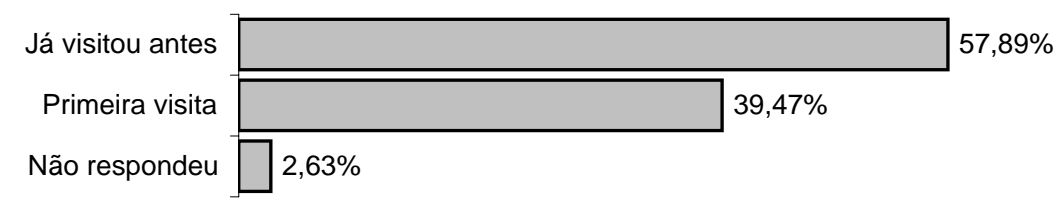

(quesionários respondidos = 296)

Pirenópolis - Julho / 2003

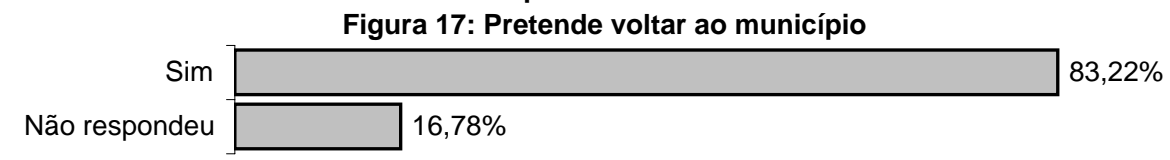

(quesionários respondidos $=253$ )

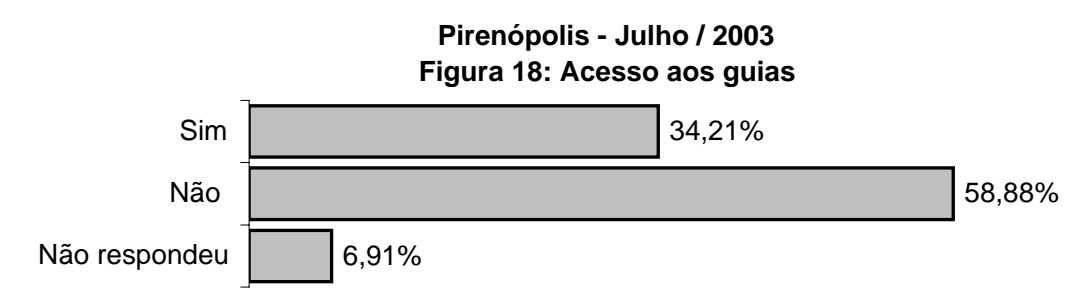

(quesionários respondidos $=\mathbf{2 8 3}$ )

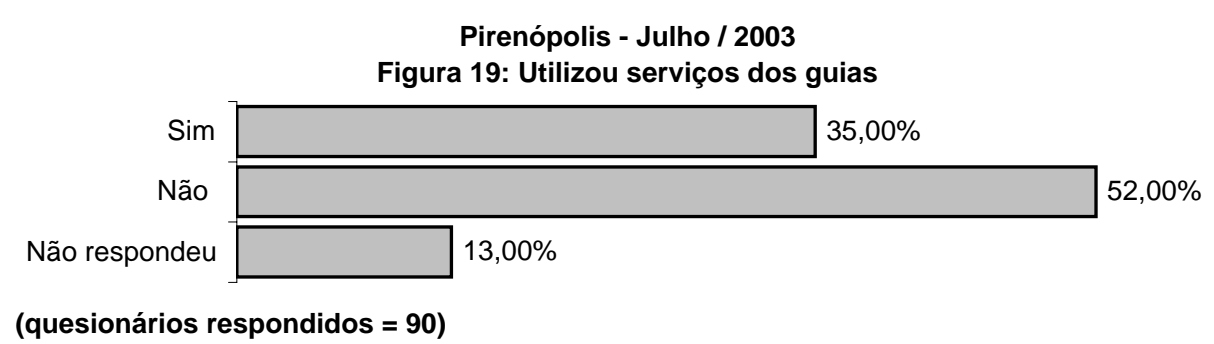

(quesionários respondidos $=90$ )

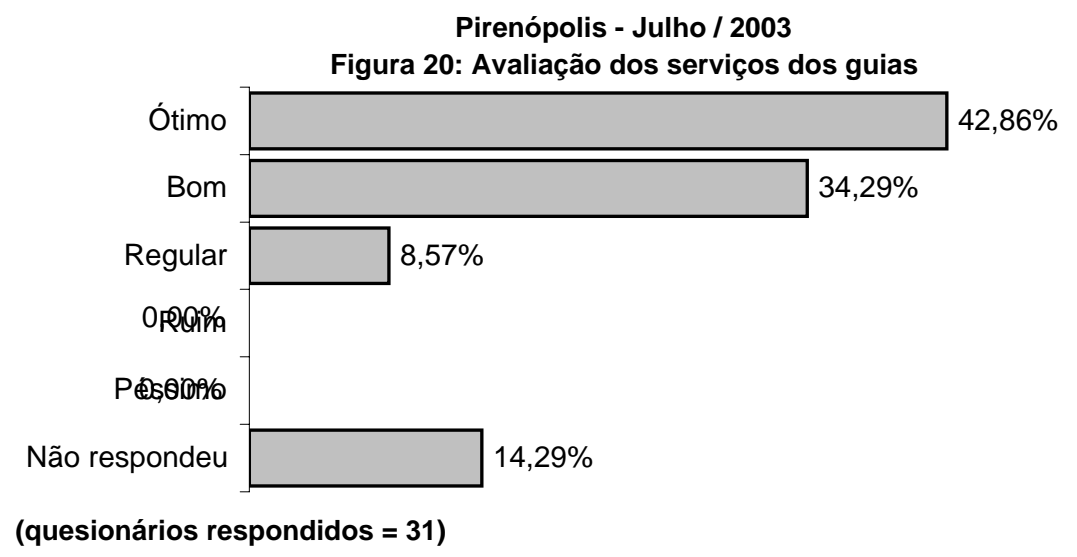

Férias de Julho - Percepção do Visitante 

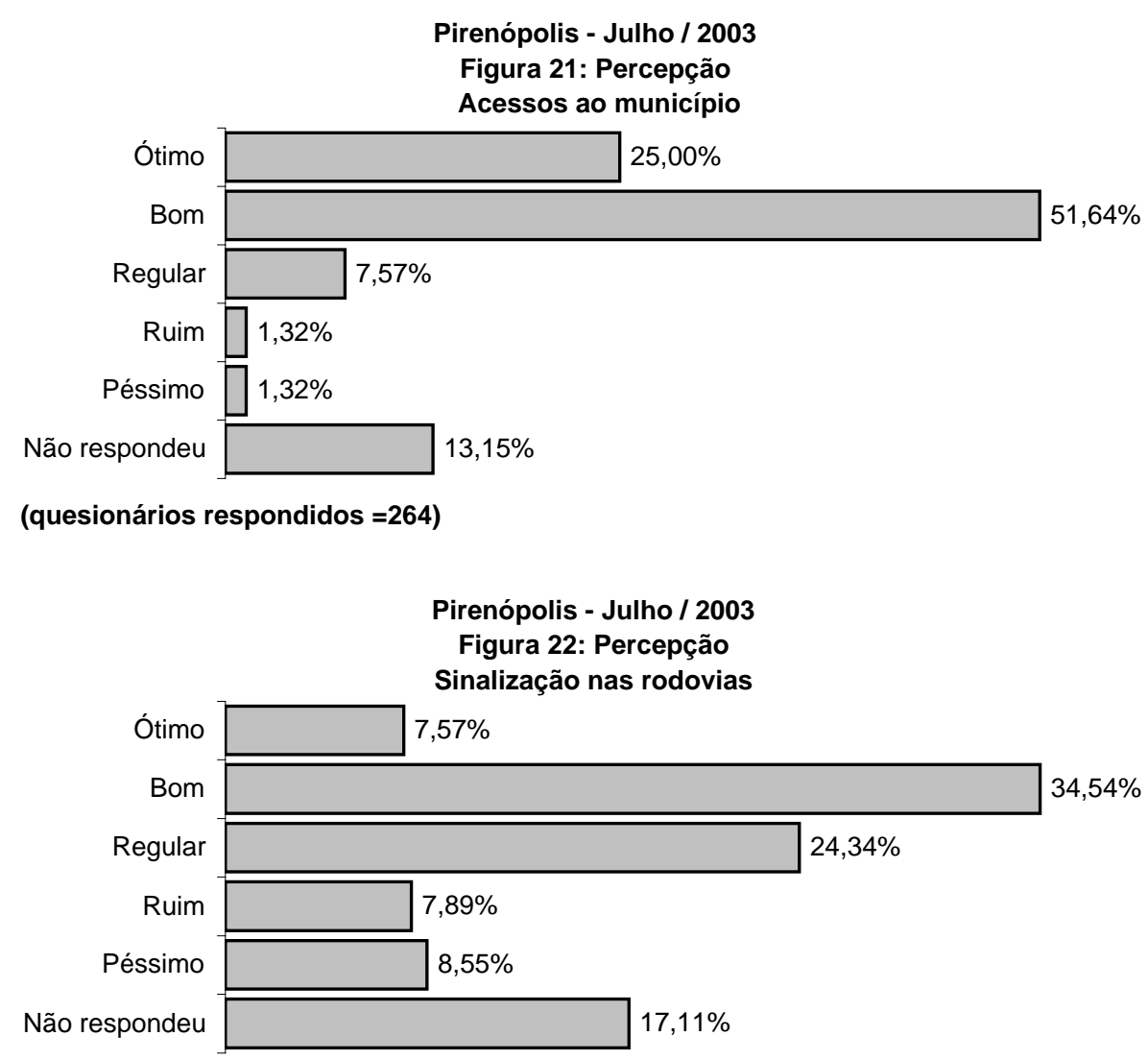

(quesionários respondidos =252)

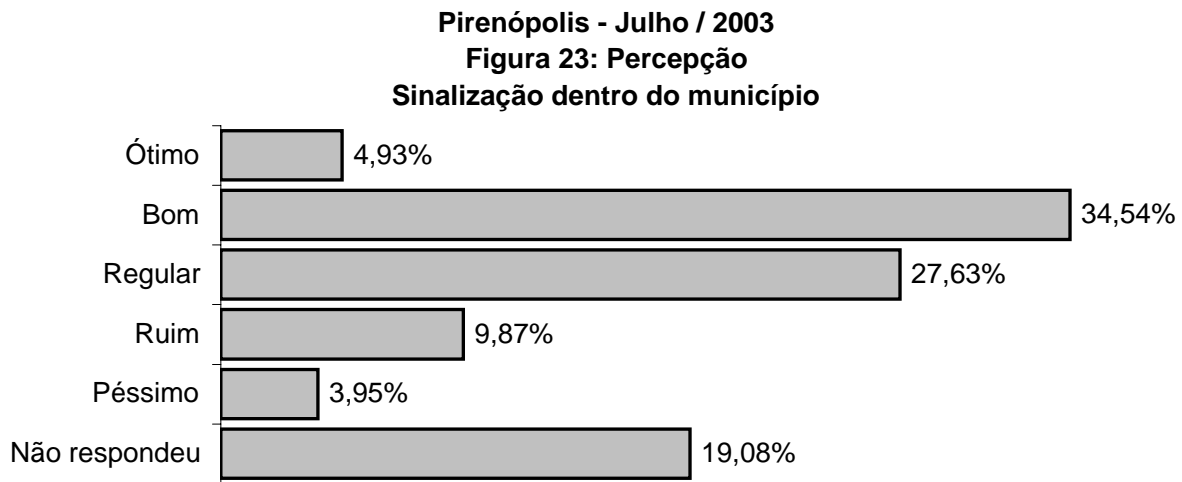

(quesionários respondidos =246) 


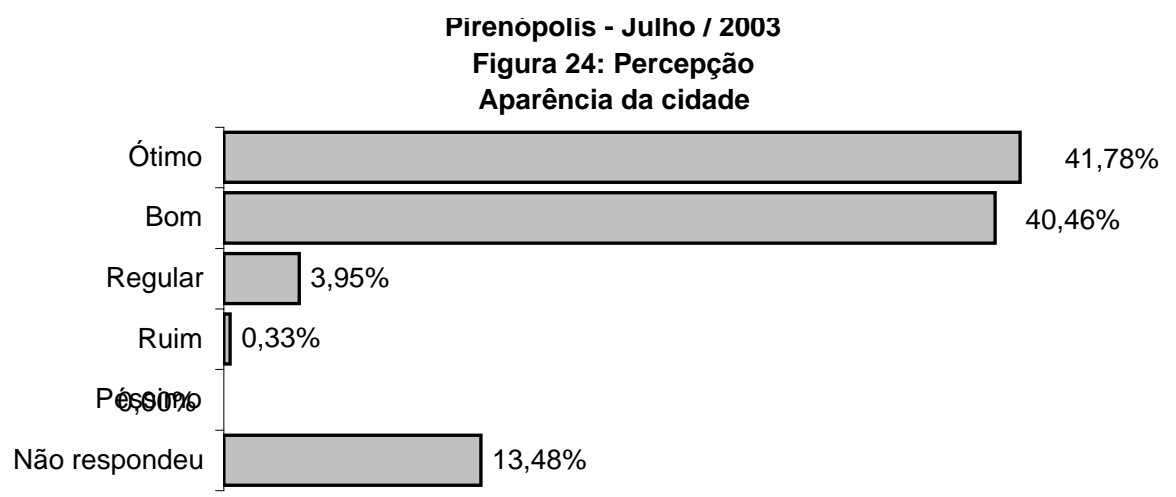

(quesionários respondidos =263)

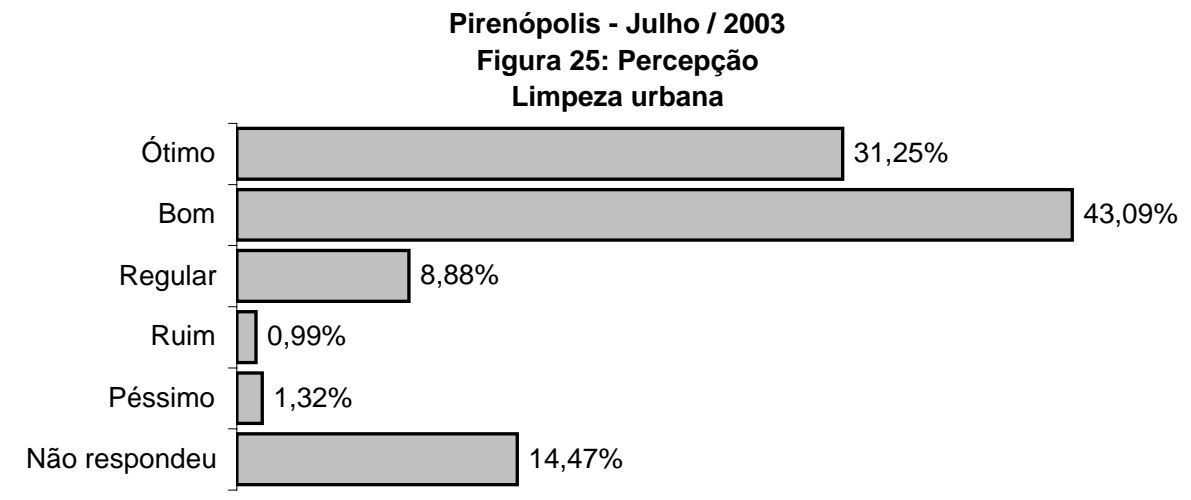

(quesionários respondidos $=\mathbf{2 6 0}$ )

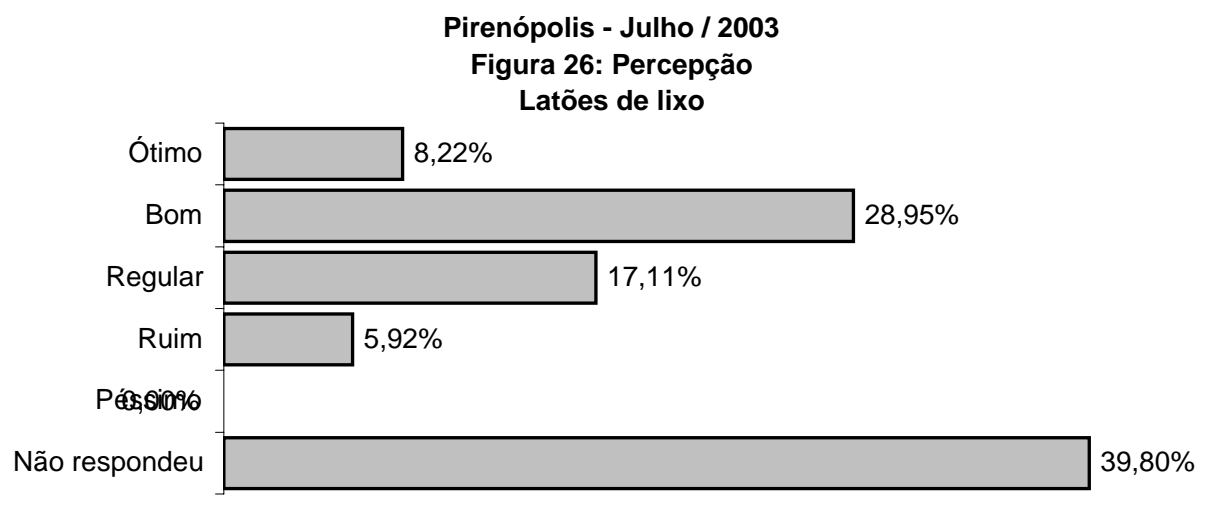

(quesionários respondidos =183) 


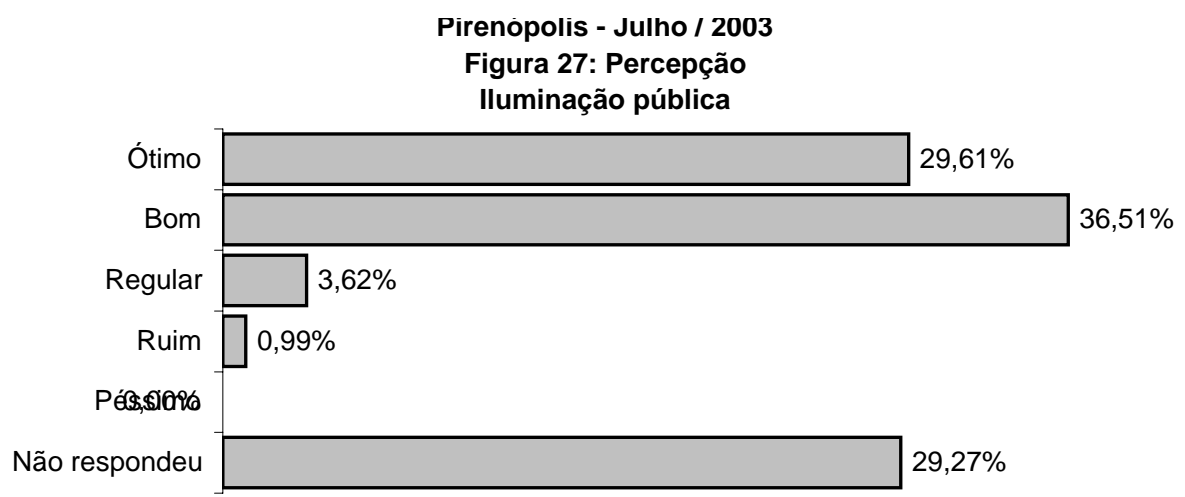

(quesionários respondidos =215)

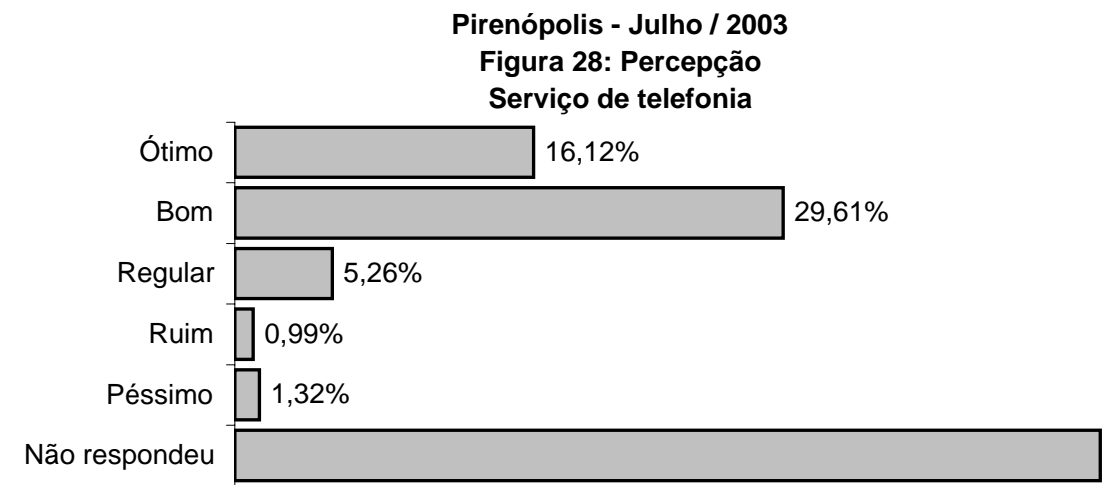

(quesionários respondidos =163)

\begin{tabular}{|c|c|}
\hline & $\begin{array}{l}\text { Pirenópolis - Julho / } 2003 \\
\text { Figura 29: Percepção } \\
\text { Serviço de transporte de uso público }\end{array}$ \\
\hline Ótimo & $0,66 \%$ \\
\hline Bom & $3,29 \%$ \\
\hline Regular & $2,63 \%$ \\
\hline Ruim & $0,66 \%$ \\
\hline Péssimo & $1,32 \%$ \\
\hline espondeu & \\
\hline
\end{tabular}

(quesionários respondidos =27) 


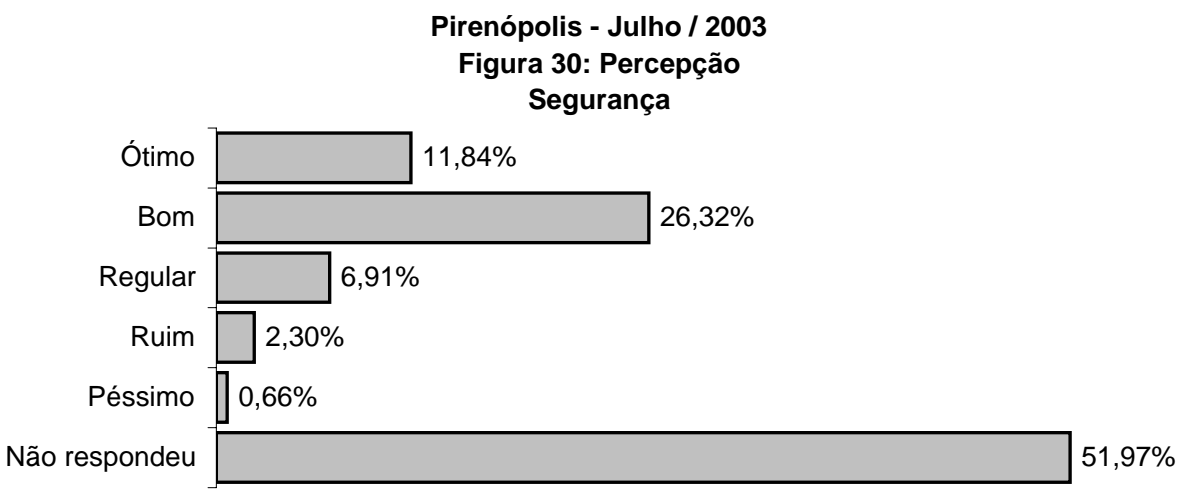

(quesionários respondidos =147)

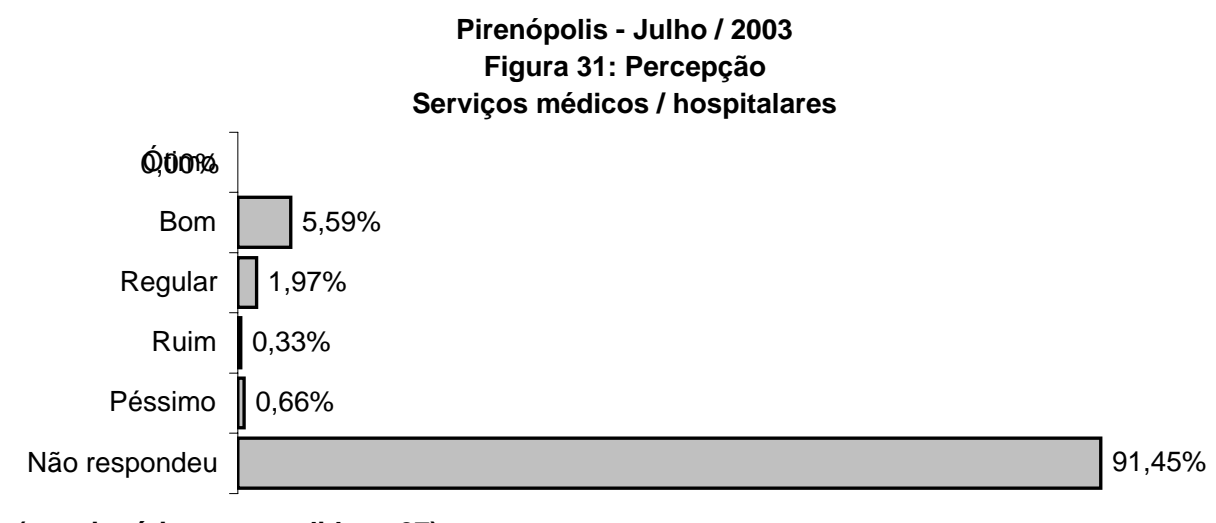

(quesionários respondidos =27)

\section{AVALIAÇÃO DOS ATRATIVOS}

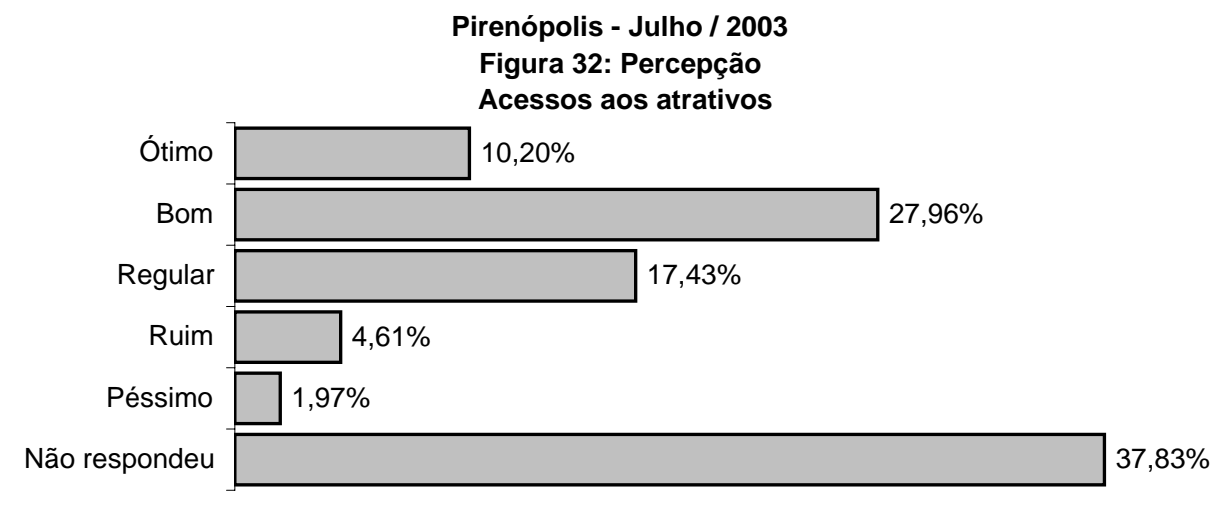

(quesionários respondidos =189) 


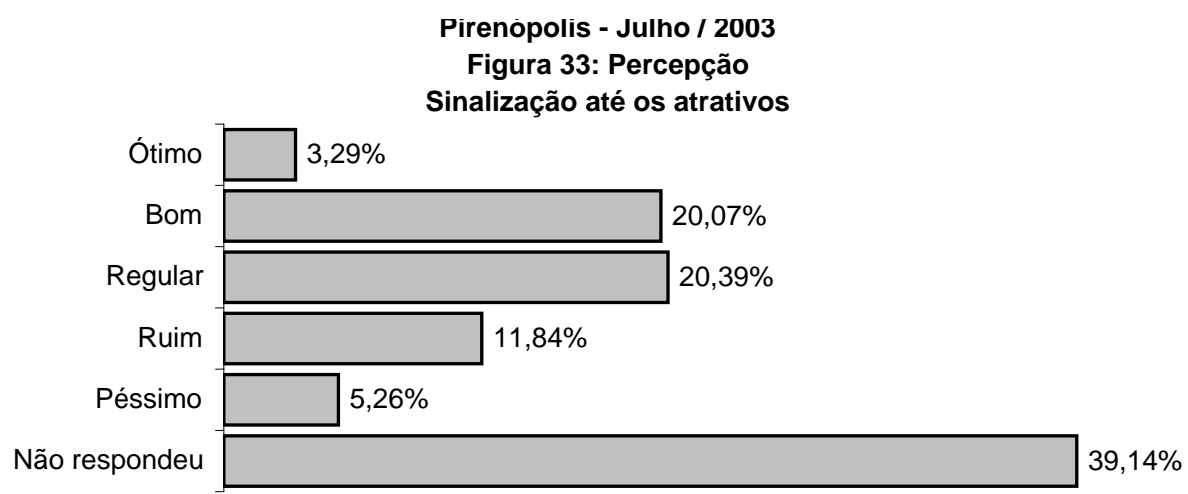

(quesionários respondidos =185)

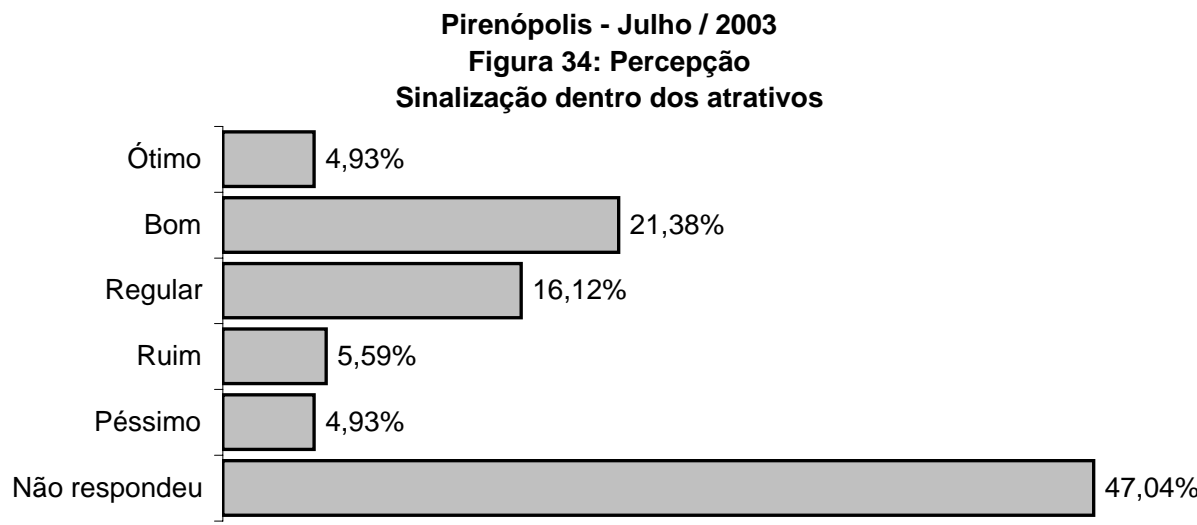

(quesionários respondidos =162)

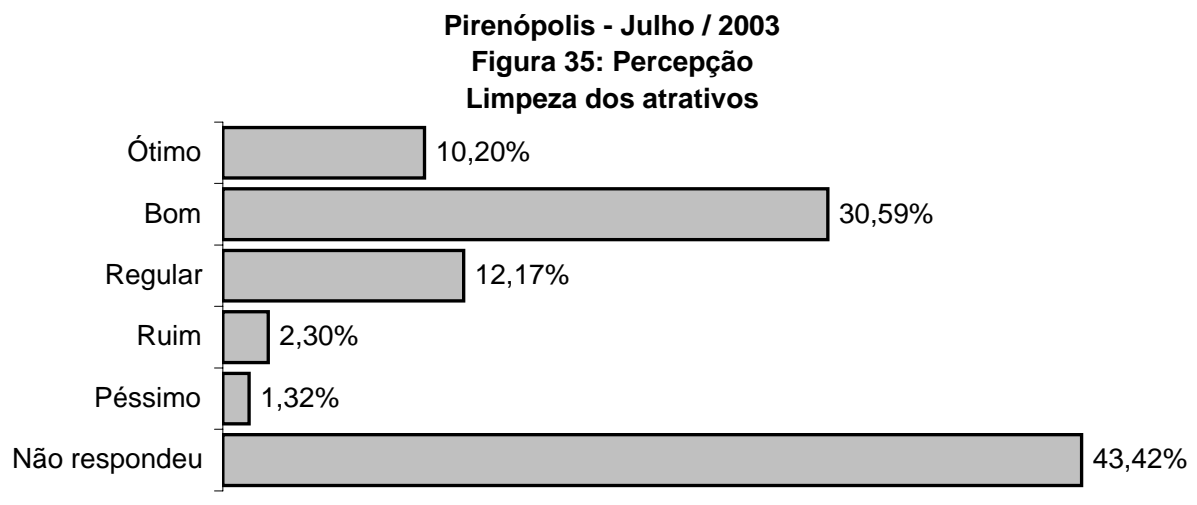

(quesionários respondidos =173) 


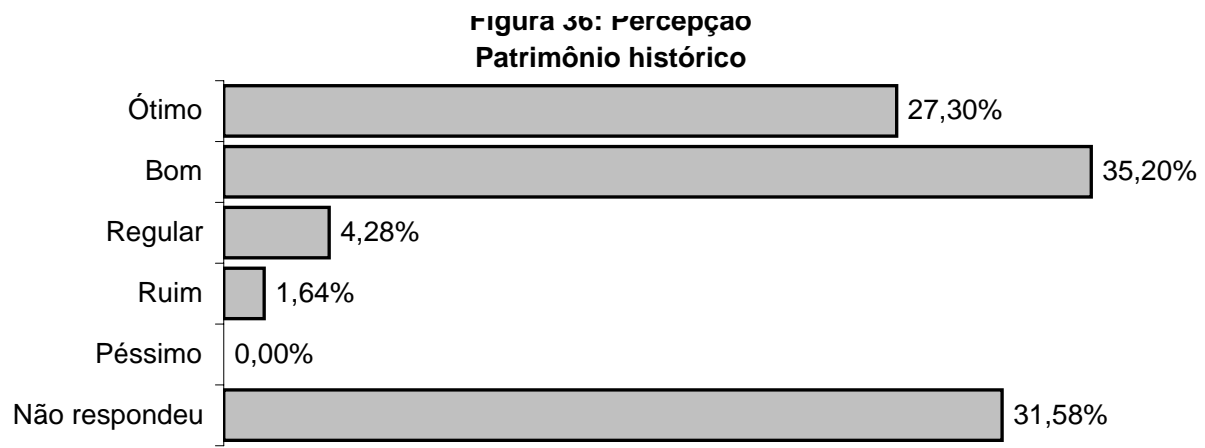

(quesionários respondidos =173)

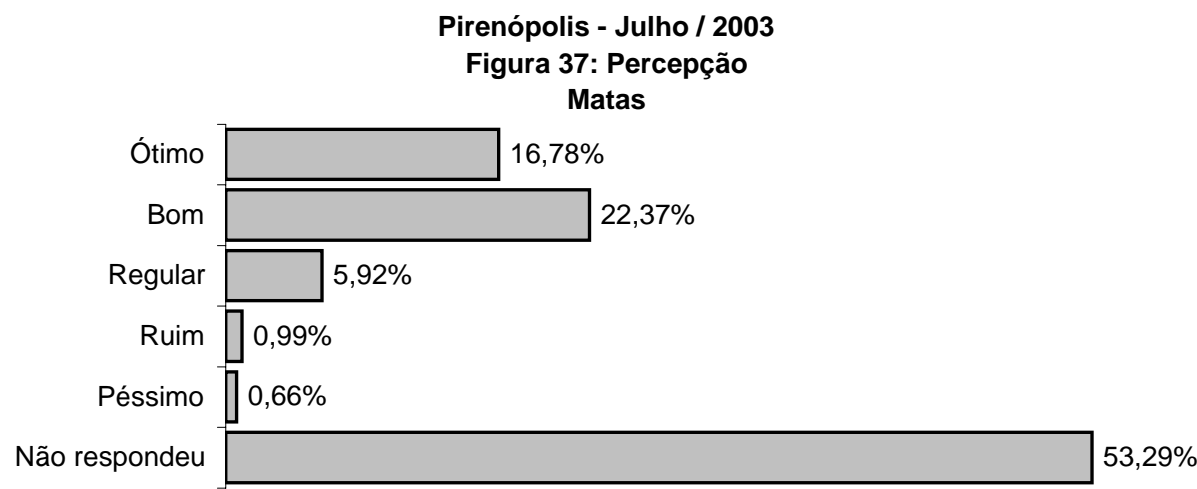

(quesionários respondidos =143)

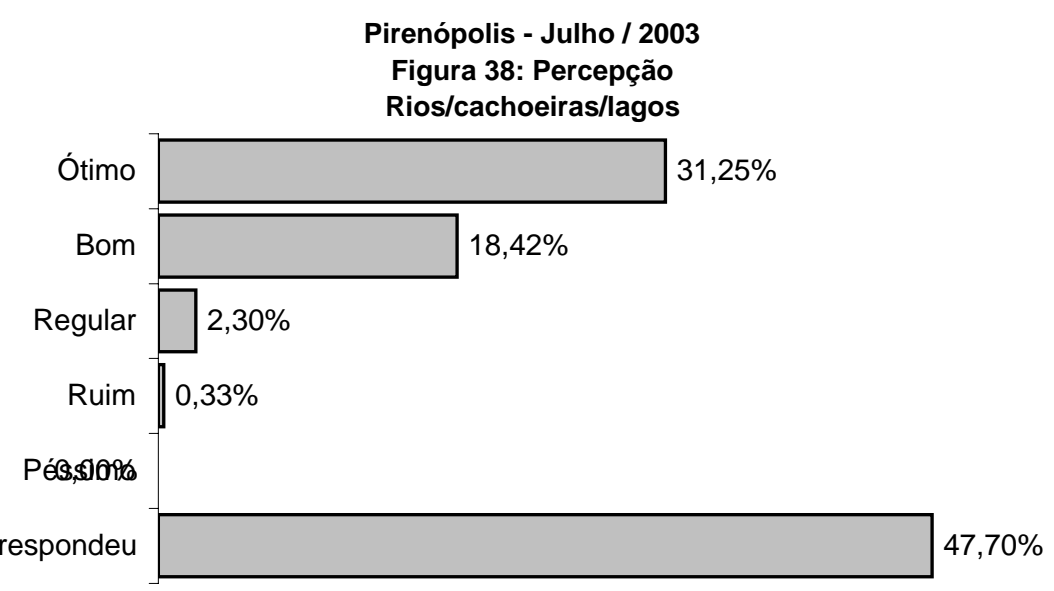

(quesionários respondidos =160) 


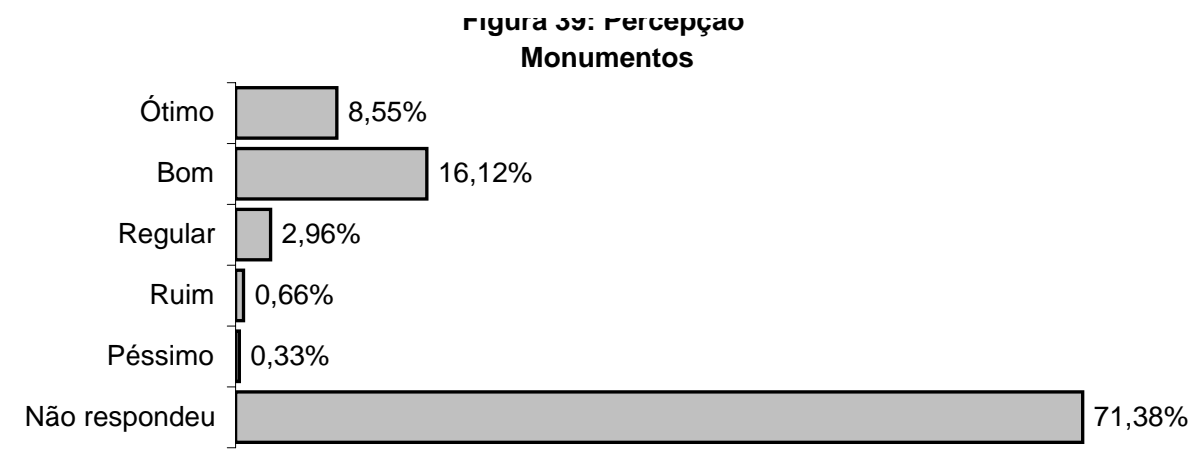

(quesionários respondidos = 88)

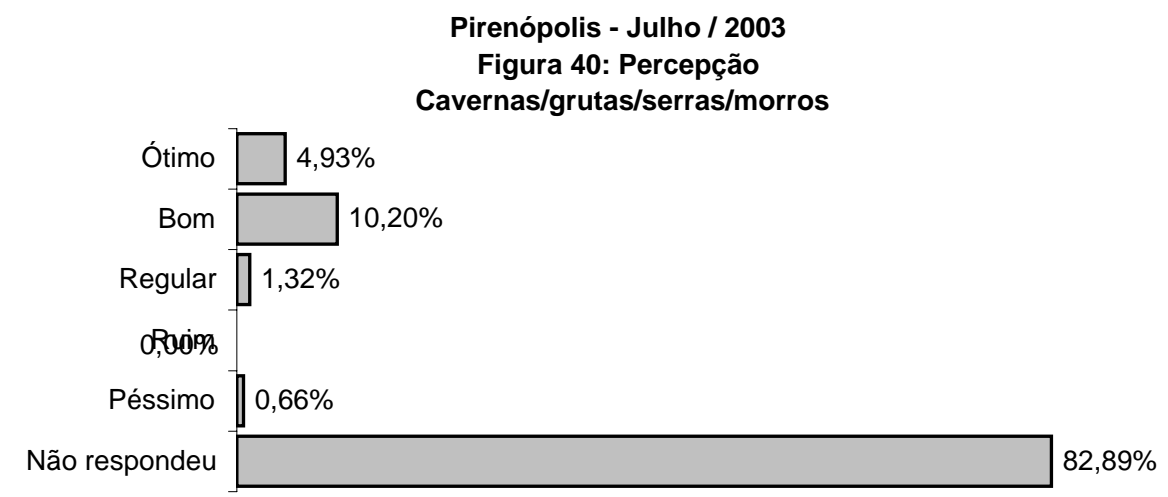

(quesionários respondidos = 53)

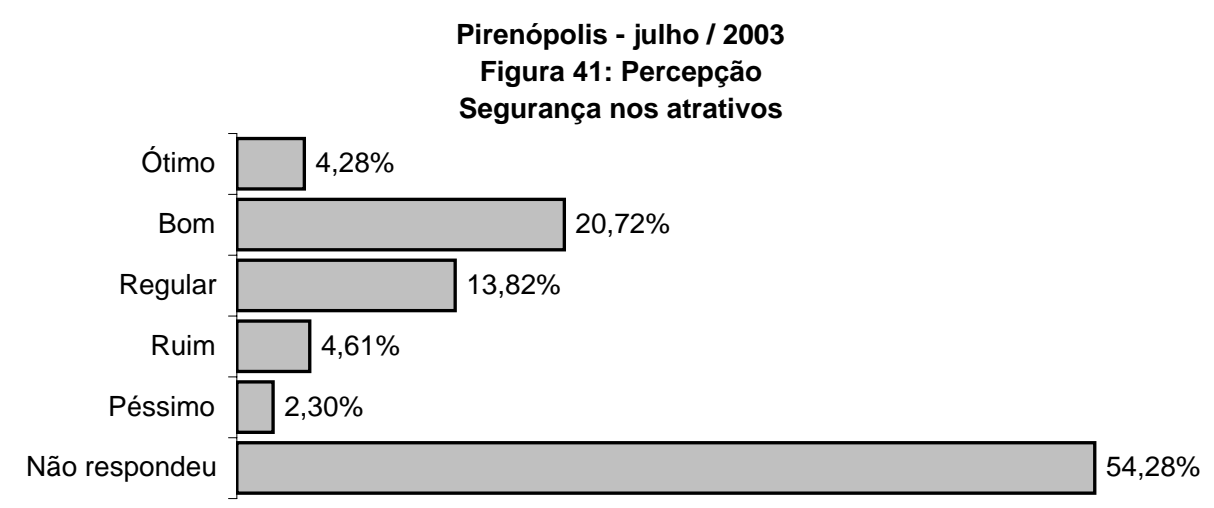

(quesionários respondidos $=140$ ) 


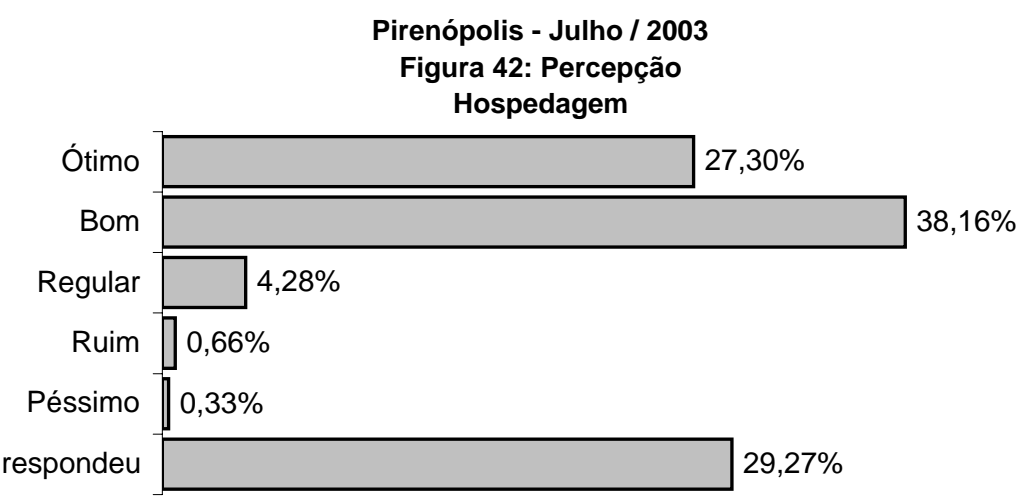

(quesionários respondidos $=\mathbf{2 1 5}$ )

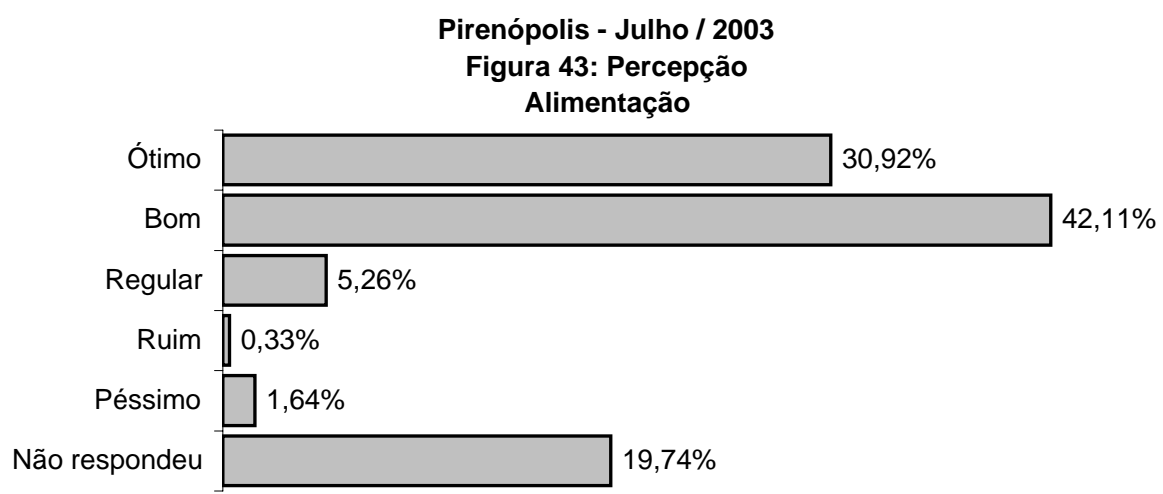

(quesionários respondidos $=$ 244)

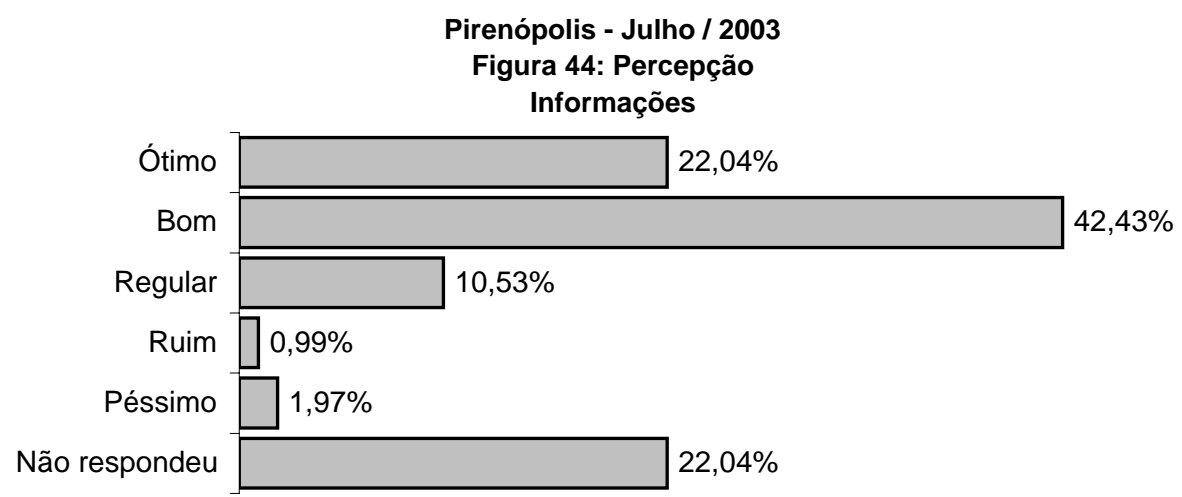

(quesionários respondidos $=237$ ) 


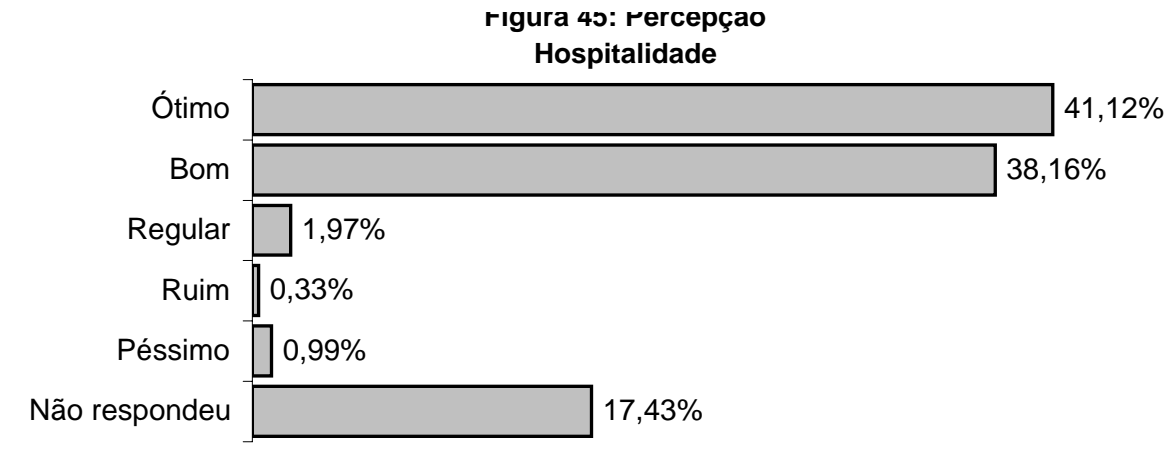

(quesionários respondidos $=237$ )

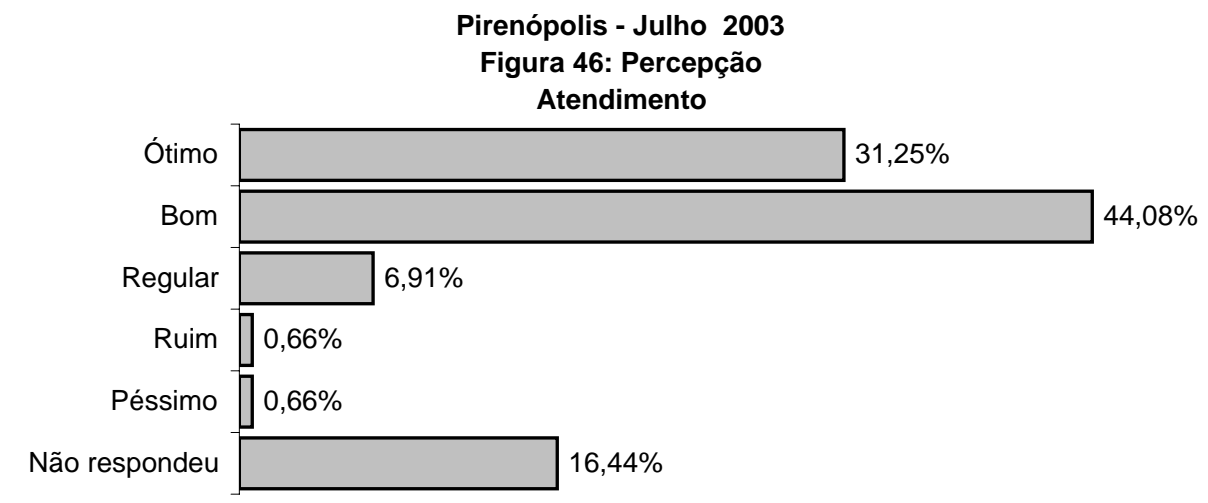

(quesionários respondidos $=254$ )

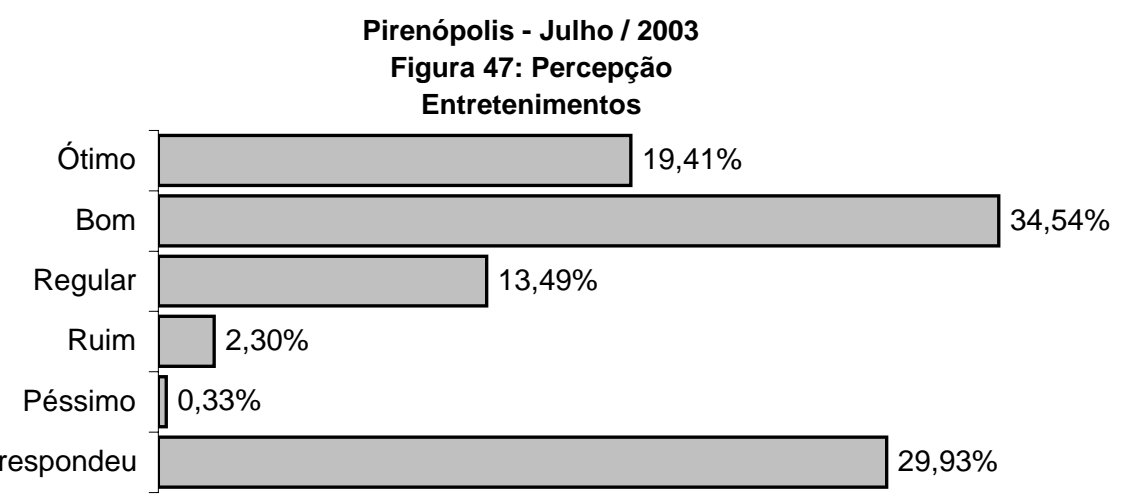

(quesionários respondidos $=\mathbf{2 1 3}$ ) 


\begin{tabular}{|c|c|c|c|}
\hline & $\begin{array}{r}\text { rigura 46: } \\
\text { Prec }\end{array}$ & & \\
\hline Ótimo & $3,29 \%$ & & \\
\hline Bom & & & $28,62 \%$ \\
\hline Regular & & & $28,29 \%$ \\
\hline Ruim & $10,86 \%$ & & \\
\hline Péssimo & $8,88 \%$ & & \\
\hline Não respondeu & & $20,06 \%$ & \\
\hline
\end{tabular}

(quesionários respondidos $=243$ ) 


\section{ANEXOS}

Anexo B:

Questionário - Semana Santa

Questionário - Final de semana comum

Questionário - Festa do Divino (Cavalhadas)

Questionário - Férias de Julho

Obs: Os questionários foram cedidos pelo Grupo Nativa 


\section{Questionário - Semana Santa / 2003}

\begin{tabular}{l|l|l|l|l|l|l}
\hline DATA: & 1,1 & HORA: & & PESQUISADOR: & CIDADE: & \\
\hline LOCAL: & \multicolumn{1}{c}{$\begin{array}{l}\text { ALTA TEMPORADA: } \\
\text { BAIXA TEMPORADA: }\end{array}$} \\
\hline
\end{tabular}

\section{PERFIL DO VISITANTE}

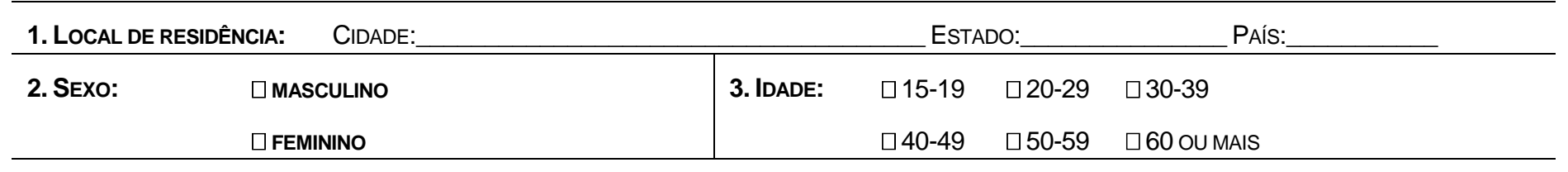

\begin{tabular}{llll}
\hline 4. HÁBITO DE VIAGEM: & $\square$ SOZINHO $\square$ UM CASAL $\square$ COM FAMÍLIA $\square$ COM AMIGOS $\square$ EXCURSÃo \\
\hline
\end{tabular}

5. MEIO DE TRANSPORTE: $\quad \square$ CARRO $\square$ ÔNIBUS $\square$ MOTO $\square$ AVIÃo OUTROS

6.GASTO MÉDIO POR DIA:

6.1. QUANTAS PESSOAS ESTÃo INCLUÍDAS NESTE GASTO?

7. LOCAL DE HOSPEDAGEM: $\quad \square$ HOTEL / POUSADA / APART-HOTEL $\square$ CASA ALUGADA $\square$ CASA DE AMIGOS / PARENTES

\begin{tabular}{|c|c|c|c|c|}
\hline & $\square$ CAMPING & $\square$ CASA PRÓPRIA & $\square$ OUtros & \\
\hline \multirow[t]{3}{*}{ 8. MOTIVO DA VIAGEM: } & $\square$ TURISMO & $\square$ Negócios & $\square$ CONGRESSO / CONVENÇÃO & $\square$ RELIGIÃO/PEREGRINAÇÃo \\
\hline & \multicolumn{2}{|c|}{$\square$ VISITAR FAMILIARES / AMIGOS } & $\square$ ESTUDO/ENSINO/PESQUISA & $\square$ TRATAMENTO DE SAÚDE \\
\hline & \multicolumn{3}{|l|}{ OUTROS } & \\
\hline
\end{tabular}

9. TEMPO DE PERMANÊNCIA: \begin{tabular}{ll} 
10. COMO VOCÊ FICOU SABENDO & $\square$ FOLDERS/GUIAS $\square$ INTERNET $\square$ INFORMAÇÃO DE PARENTES I AMIGOS $\square$ JORNAL $\square$ REVISTA $\square$ RÁDIO \\
SOBRE ESTE LUGAR/ESTA REGIÃO? & $\square$ TELEVISÃO OUTROS \\
\hline
\end{tabular}

\begin{tabular}{|c|c|c|c|c|c|}
\hline 11. EsCOLARIDADE: & $\square$ SEM ESCOLARIDADE & $\square$ FUNDAMENTAL & $\square$ MÉDIO & $\square$ SUPERIOR & $\square$ PóS-GRADUAÇÃo \\
\hline 12. LOCAL DE TRABALHO: & $\begin{array}{l}\square \text { EMPREGo PRIVADO } \\
\square \text { ESTUDANTE }\end{array}$ & $\begin{array}{l}\square \text { EMPREGo PúBLICO } \\
\square \text { APOSENTADO }\end{array}$ & \multicolumn{2}{|c|}{$\begin{array}{l}\square \text { PROFISSIONAL LIBERAL } \\
\square \text { DO LAR }\end{array}$} & $\square$ EMPRESÁRIO \\
\hline & OUTROS & & & & \\
\hline
\end{tabular}

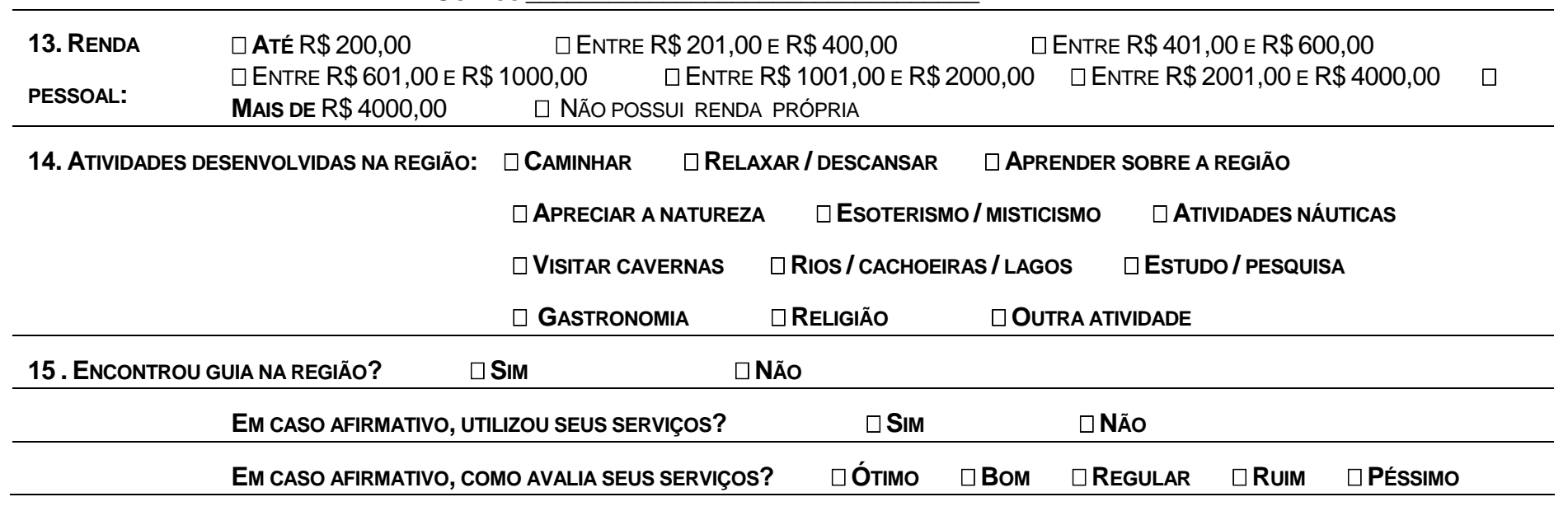




\section{Questionário - Festa do Divino - Cavalhadas / 2003}

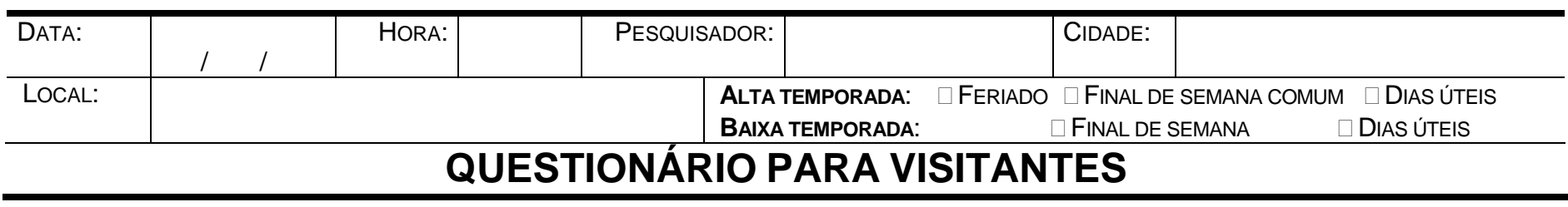

\section{PERFIL DO VISITANTE}

1. LOCAL DE RESIDÊNCIA: CIDADE:

ESTADO:

PAís:

\begin{tabular}{|c|c|c|c|c|c|}
\hline \multirow[t]{2}{*}{ 2. SeXo: } & $\square$ MASCULINO & 3. IDADE: & $\square 15-19$ & $\square 20-29$ & $\square 30-39$ \\
\hline & $\square$ FEMININO & & $\square 40-49$ & $\square 50-59$ & $\square 60$ OU MAIS \\
\hline
\end{tabular}

4. HÁBITO DE VIAGEM: $\square$ SOZINHO $\square$ UM CASAL $\square$ COM FAMÍLIA $\square$ COM AMIGOS $\square$ EXCURSÃo

5. Agrupamento

6. MEIO de TRANSPORTE: $\square$ CARRO $\square$ ÔNIBUS $\square$ MOTO $\square$ AVIÃo OUTROS

7.GASTO MÉDIO POR DIA:

7.1 QUANTAS PESSOAS ESTÃO INCLUÍDAS NESTE GASTO?

\begin{tabular}{|c|c|c|c|c|}
\hline \multirow[t]{2}{*}{ 8. LOCAL DE HOSPEDAGEM: } & \multicolumn{2}{|c|}{$\square$ HOTEL / POUSADA / APART-HOTEL } & $\square$ CASA ALUGADA & \multirow[t]{2}{*}{$\square$ CASA DE AMIGOS / PARENTES } \\
\hline & $\square$ CAMPING & $\square$ CASA PRÓPRIA & $\square$ OUTROS & \\
\hline \multirow[t]{3}{*}{ 9. MOTIVO DA VIAGEM: } & $\square$ TURISMO & $\square$ Negócios & $\square$ CONGRESSO / CONVENÇÃO & $\square$ RELIGIÃO/PEREGRINAÇÃO \\
\hline & \multicolumn{2}{|c|}{$\square$ VISITAR FAMILIARES / AMIGOS } & $\square$ ESTUDO/ENSINO/PESQUISA & $\square$ TRATAMENTO DE SAÚDE \\
\hline & \multicolumn{2}{|l|}{ OUTROS } & & \\
\hline
\end{tabular}

10. TEMPO DE PERMANÊNCIA:

11. COMO VOCÊ FICOU SABENDO

$\square$ FoldERS/GUIAS $\square$ INTERNET $\square$ INFORMAÇÃO DE PARENTES / AMIGOS $\square$ JORNAL $\square$ REVISTA $\square$ RÁDIO SOBRE ESTE LUGAR/ESTA REGIÃO?

ITELEVISÃo OUTROS

\begin{tabular}{llllll}
\hline 12. ESCOLARIDADE: & $\square$ SEM ESCOLARIDADE & $\square$ FUNDAMENTAL & $\square$ MÉdIO & $\square$ SUPERIOR & $\square$ Pós-GRADUAÇÃo \\
\hline 13. LOCAL DE TRABALHO: & $\square$ EMPREGo PRIVADO & $\square$ EMPREGO PúBLICO & $\square$ PROFISSIONAL LIBERAL & $\square$ EMPRESÁRIO \\
& $\square$ ESTUDANTE & $\square$ APOSENTADO & $\square$ Do LAR &
\end{tabular}

OUTROS

\begin{tabular}{|c|c|c|c|c|}
\hline \multirow{3}{*}{$\begin{array}{l}\text { 14. RENDA } \\
\text { PESSOAL: }\end{array}$} & $\square$ ATÉ R\$200,00 & \multicolumn{2}{|c|}{$\square$ ENTRE R $\$ 201,00$ E R $\$ 400,00$} & ～ENTRE R \$ 401,00 E R \$ 600,00 \\
\hline & \multicolumn{2}{|c|}{$\square$ ENTRE R $\$ 601,00$ E R $\$ 1000,00$} & पENTRE R $\$ 1001,00$ E R $\$ 2000,00$ & \multirow[t]{2}{*}{ ENTRE R $\$ 2001,00$ E R $\$ 4000$} \\
\hline & MAIS DE $\mathrm{R} \$ 4000,00$ & $\square$ NÃO POSSUI RENDA & PRÓPRIA & \\
\hline \multirow[t]{4}{*}{ 15. ATIVIDAL } & SENVOLVIDAS NA REGIÃO: & $\square$ CAMINHAR & KAR / DESCANSAR & SOBRE A REGIÃO \\
\hline & & $\square$ APRECIAR A NATUREZA & $\square$ ESOTERISMO / MISTICISMO & $\square$ ATIVIDADES NÁUTICAS \\
\hline & & $\square$ VISITAR CAVERNAS & $\square$ RIOS / CACHOEIRAS / LAGOS & $\square$ ESTUDO / PESQUISA \\
\hline & & $\square$ GASTRONOMIA & $\square$ RELIGIÃo & IVIDADE \\
\hline
\end{tabular}

16. Já visitou o município ? $\square$ Primeira visita $\square$ Já visitou antes
17. PRetende voltar?
$\square$ SIM
$\square$ NÃo

EM CASO NEGATIVO, POR QUÊ ?

18. ENCONTROU GUIA NA REGIÃO?

$\square$ SIM

$\square$ Não

EM CASO AFIRMATIVO, UTILIZOU SEUS SERVIÇOS?

$\square$ SIM

$\square$ NÃo

EM CASO AFIRMATIVO, COMO AVALIA SEUS SERVIÇOS?

$\square$ ÓtIMO $\square$ BoM $\square$ REGULAR $\square$ RUIM $\square$ PÉSSIMO




\section{PERCEPÇÃO DO VISITANTE}

OBS.: EM CASO DE DESCONHECIMENTO, NÃO RESPONDER.

\section{AVALIAÇÃO DA INFRA-ESTRUTURA DO MUNICÍPIO}

\begin{tabular}{lcccc}
\hline & ÓtIMO & BoM & REGULAR & RUIM \\
\hline 21. ACESSO AO MUNICÍPIO & $\square$ & $\square$ & $\square$ & $\square$ \\
\hline 22. SINALIZAÇÃO NAS RODOVIAS & $\square$ & $\square$ & $\square$ & $\square$ \\
\hline 23. SINALIZAÇÃO DENTRO DO MUNICÍPIO & $\square$ & $\square$ & $\square$ \\
\hline 24. APARÊNCIA DA CIDADE & $\square$ & $\square$ & $\square$ \\
\hline 25. LIMPEZA URBANA & $\square$ & $\square$ & $\square$ \\
\hline 26. LATÕES DE LIXO & $\square$ & $\square$ & $\square$ \\
\hline 27. ILUMINAÇÃO PUBLICA & $\square$ & $\square$ & $\square$ \\
\hline 28. TELEFONE PUBLICO & $\square$ & $\square$ & $\square$ \\
\hline 29. TELEFONE CELULAR & $\square$ & $\square$ & $\square$ \\
\hline 30. SERVIÇO DE TRANSPORTE DE USO PUBLICO & $\square$ & $\square$ & $\square$ \\
\hline 31. SEGURANÇA & $\square$ & $\square$ & $\square$ \\
\hline 32. SERVIÇOS MÉDICOS / HOSPITALARES & $\square$ & $\square$ & $\square$ \\
\hline
\end{tabular}

AVALIAÇÃO DOS ATRATIVOS DO MUNICÍPIO

\begin{tabular}{|c|c|c|c|c|c|}
\hline & Óтıмо & Bom & REGULAR & RUIM & PÉSSIMO \\
\hline 33. ACESSO AOS ATRATIVOS & $\square$ & $\square$ & $\square$ & $\square$ & $\square$ \\
\hline 34. INFRA-ESTRUTURA DOS ATRATIVOS & $\square$ & $\square$ & $\square$ & $\square$ & $\square$ \\
\hline 35. SINALIZAÇÃO ATÉ OS ATRATIVOS & $\square$ & $\square$ & $\square$ & $\square$ & $\square$ \\
\hline 36. SINALIZAÇÃO DENTRO DOS ATRATIVOS & $\square$ & $\square$ & $\square$ & $\square$ & $\square$ \\
\hline 37. LIMPEZA DOS ATRATIVOS & $\square$ & $\square$ & $\square$ & $\square$ & $\square$ \\
\hline 38. PATRIMÔNIO HISTÓRICO & $\square$ & $\square$ & $\square$ & $\square$ & $\square$ \\
\hline 39. MATAS & $\square$ & $\square$ & $\square$ & $\square$ & $\square$ \\
\hline 40. RIOS/CACHOEIRAS/LAGOS & $\square$ & $\square$ & $\square$ & $\square$ & $\square$ \\
\hline 41. MONUMENTOS & $\square$ & $\square$ & $\square$ & $\square$ & $\square$ \\
\hline 42. FESTIVIDADES & $\square$ & $\square$ & $\square$ & $\square$ & $\square$ \\
\hline 43. CAVERNAS/GRUTAS/SERRAS/MORROS & $\square$ & $\square$ & $\square$ & $\square$ & $\square$ \\
\hline
\end{tabular}

\section{AVALIAÇÃO DOS EQUIPAMENTOS E SERVIÇOS TURÍSTICOS DO MUNICÍPIO}

\begin{tabular}{lcccc}
\hline & ÓTIMO & BOM & REGULAR & RUIM \\
\hline 44. HOSPEDAGEM & $\square$ & $\square$ & $\square$ & $\square$ \\
\hline 45. ALIMENTAÇÃO & $\square$ & $\square$ & $\square$ & $\square$ \\
\hline 46. INFORMAÇÕES & $\square$ & $\square$ & $\square$ & $\square$ \\
\hline 47. HOSPITALIDADE & $\square$ & $\square$ & $\square$ \\
\hline 48. ATENDIMENTO & $\square$ & $\square$ & $\square$ \\
\hline 49. ENTRETENIMENTOS & $\square$ & $\square$ & $\square$ \\
\hline 50. PREÇOS & $\square$ & $\square$ & $\square$ \\
\hline
\end{tabular}

\section{QUestionário CEDIDO PELO GRUPo NATIVA E ADAPTADo PARA A PESQUISA}




\section{PERCEPÇÃO DO VISITANTE}

OBS.: EM CASO DE DESCONHECIMENTO, NÃO RESPONDER.

\section{AVALIAÇÃO DA INFRA-ESTRUTURA DO MUNICÍPIO}

\begin{tabular}{lcccc}
\hline & ÓTIMO & BOM & REGULAR & RUIM \\
\hline 18. ACESSO AO MUNICÍPIO & $\square$ & $\square$ & $\square$ & $\square$ \\
\hline 19. ACESSO AOS ATRATIVOS & $\square$ & $\square$ & $\square$ & $\square$ \\
\hline 20. INFRA-ESTRUTURA DA CIDADE & $\square$ & $\square$ & $\square$ \\
\hline 21. LIMPEZA URBANA & $\square$ & $\square$ & $\square$ \\
\hline 22. SINALIZAÇÃO NAS RODOVIAS & $\square$ & $\square$ & $\square$ \\
\hline 23. APARÊNCIA DA CIDADE & $\square$ & $\square$ & $\square$ \\
\hline 24. ILUMINAÇÃO PÚBLICA & $\square$ & $\square$ & $\square$ \\
\hline 25. LATÕES DE LIXO & $\square$ & $\square$ & $\square$ \\
\hline 26. SEGURANÇA & $\square$ & $\square$ & $\square$ \\
\hline 27. SERVIÇOS MÉDICOS/ HOSPITALARES & $\square$ & $\square$ & $\square$ \\
\hline
\end{tabular}

\section{AVALIAÇÃO DOS ATRATIVOS DO MUNICÍPIO}

\begin{tabular}{lcccc}
\hline & ÓTIMO & BOM & REGULAR & RUIM \\
\hline 28. QUALIDADE AMBIENTAL DOS ATRATIVOS & $\square$ & $\square$ & $\square$ & $\square$ \\
\hline 29. INFRA-ESTRUTURA DOS ATRATIVOS & $\square$ & $\square$ & $\square$ & $\square$ \\
\hline 30. PATRIMÔNIO HISTÓRICO & $\square$ & $\square$ & $\square$ & $\square$ \\
\hline 31. DIVERSIDADE DE PROGRAMAS/ PRODUTOS & $\square$ & $\square$ & $\square$ & $\square$ \\
\hline 32. LIMPEZA DOS ATRATIVOS & $\square$ & $\square$ & $\square$ & $\square$ \\
\hline 33. SINALIZAÇÃO DENTRO DOS ATRATIVOS & $\square$ & $\square$ & $\square$ \\
\hline
\end{tabular}

\section{AVALIAÇÃO DOS EQUIPAMENTOS E SERVIÇOS TURÍSTICOS DO MUNICÍPIO}

\begin{tabular}{lcccc}
\hline & ÓTIMO & BoM & REGULAR & RUIM \\
\hline 34. HOSPEDAGEM & $\square$ & $\square$ & $\square$ & $\square$ \\
\hline 35. ALIMENTAÇÃO & $\square$ & $\square$ & $\square$ & $\square$ \\
\hline 36. INFORMAÇÕES & $\square$ & $\square$ & $\square$ & $\square$ \\
\hline 37. HOSPITALIDADE & $\square$ & $\square$ & $\square$ & $\square$ \\
\hline 38. ATENDIMENTO & $\square$ & $\square$ & $\square$ \\
\hline 39. ENTRETENIMENTOS & $\square$ & $\square$ & $\square$ \\
\hline 40. PREÇOS & $\square$ & $\square$ & $\square$ & $\square$ \\
\hline
\end{tabular}

\section{QUESTIONÁRIO CEDIDO PELO GRUPO NATIVA E ADAPTADO PARA A PESQUISA}




\section{Questionário - Final de Semana Comum / 2003}

\begin{tabular}{l|l|l|l|l|l|l}
\hline DATA: & 1,1 & HORA: & & PESQUISADOR: & CIDADE: & \\
\hline LOCAL: & \multicolumn{8}{|c|}{$\begin{array}{l}\text { ALTA TEMPORADA: } \\
\text { BaIXA TEMPORADA: }\end{array}$} \\
\hline
\end{tabular}

\section{PERFIL DO VISITANTE}

1. LOCAL DE RESIDÊNCIA: CIDADE:

\begin{tabular}{|c|c|c|c|c|c|}
\hline \multirow[t]{2}{*}{ 2. SEXo: } & $\square$ MASCULINO & 3. IDADE: & $\square 15-19$ & $\square 20-29$ & $\square$ 30-39 \\
\hline & $\square$ FEMININO & & $\square 40-49$ & $\square 50-59$ & $\square 60$ OU MAIS \\
\hline
\end{tabular}

4. HÁBITO DE VIAGEM: $\quad \square$ SOZINHO $\square$ UMCASAL $\square$ COM FAMÍLIA $\square$ COM AMIGOS $\square$ EXCURSÃo

5. MEIO DE TRANSPORTE: $\square$ CARRO $\square$ ÔNIBUS $\square$ MOTO $\square$ AVIÃO OUTROS

\begin{tabular}{|c|c|}
\hline 6.GASTO MÉDIO POR DIA: & 6.1. QUANTAS PESSOAS ESTÃO INCLUÍDAS NESTE GASTO? \\
\hline
\end{tabular}

\begin{tabular}{|c|c|c|c|c|}
\hline \multirow[t]{2}{*}{ 7. LOCAL DE HOSPEDAGEM: } & \multicolumn{2}{|c|}{$\square$ HOTEL / POUSADA / APART-HOTEL } & $\square$ CASA ALUGADA & \multirow[t]{2}{*}{$\square$ CASA DE AMIGOS / PARENTES } \\
\hline & $\square$ CAMPING & $\square$ CASA PRÓPRIA & $\square$ OUTROS & \\
\hline \multirow[t]{3}{*}{ 8. MOTIVO DA VIAGEM: } & $\square$ TURISMO & $\square$ NEGócios & $\square$ CONGRESSO / CONVENÇÃO & $\square$ RELIGIÃO/PEREGRINAÇÃO \\
\hline & \multicolumn{2}{|c|}{$\square$ VISITAR FAMILIARES / AMIGOS } & $\square$ ESTUDO/ENSINO/PESQUISA & $\square$ TRATAMENTO DE SAÚDE \\
\hline & \multicolumn{4}{|l|}{ OUTROS } \\
\hline
\end{tabular}

9. TEMPO DE PERMANÊNCIA:

10. COMO VOCÊ FICOU SABENDO

$\square$ FOLDERS/GUIAS $\square$ INTERNET $\square$ INFORMAÇÃO DE PARENTES I AMIGOS $\square$ JORNAL $\square$ REVISTA $\square$ RÁDIO SOBRE ESTE LUGAR/ESTA REGIÃO? DTELEVISÃO OUTROS

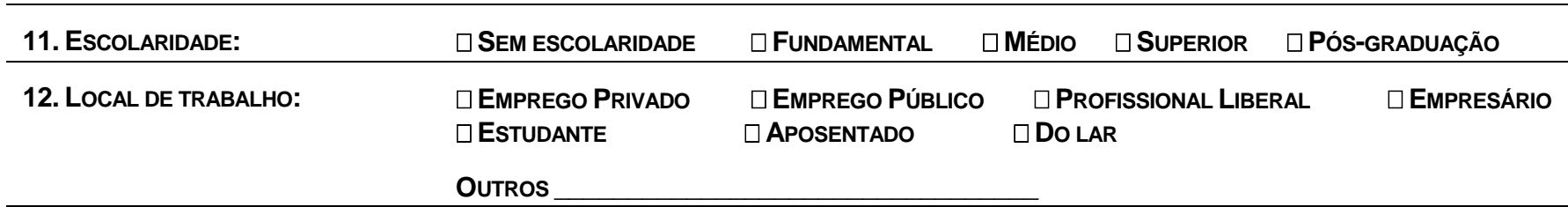

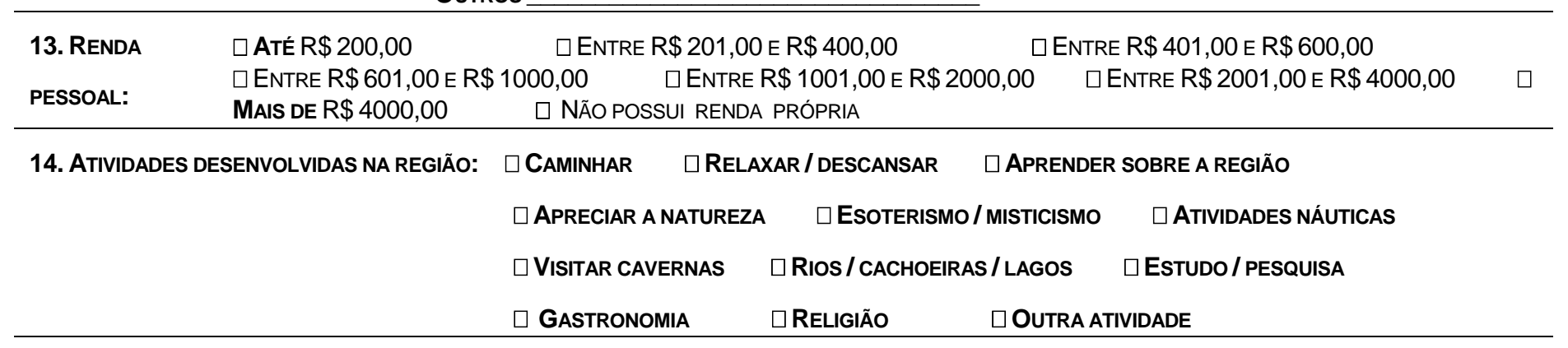

15. JÁ VISITOU O MUNICÍPIO? $\square$ PRIMEIRA VISITA $\square$ JÁ VISITOU ANTES

16. Pretende Voltar ao municípIo? ? $\square$ Sim $\square$ NÃo Em caso negativo, por quê?

17. ENCONTROU GUIA NA REGIÃO? $\square$ SIM $\square$ NÃO

EM CASO AFIRMATIVO, UTILIZOU SEUS SERVIÇOS? $\quad \square$ SIM $\quad \square$ NÃo

EM CASO AFIRMATIVO, COMO AVALIA SEUS SERVIÇOS? $\quad \square$ ÓtIMO $\quad \square$ BoM $\quad \square$ REgUlaR $\square$ RUIM $\square$ PÉSSIMO 


\section{PERCEPÇÃO DO VISITANTE}

OBS.: EM CASO DE DESCONHECIMENTO, NÃO RESPONDER.

\section{AVALIAÇÃO DA INFRA-ESTRUTURA DO MUNICÍPIO}

\begin{tabular}{|c|c|c|c|c|c|}
\hline & Óтімо & Bom & REGULAR & RUIM & PÉSSIMO \\
\hline 20. ACESSO AO MUNICÍPIO & $\square$ & $\square$ & $\square$ & $\square$ & $\square$ \\
\hline 21. SINALIZAÇÃO NAS RODOVIAS & $\square$ & $\square$ & $\square$ & $\square$ & $\square$ \\
\hline 22. SINALIZAÇÃO DENTRO DO MUNICÍPIO & $\square$ & $\square$ & $\square$ & $\square$ & $\square$ \\
\hline 23. APARÊNCIA DA CIDADE & $\square$ & $\square$ & $\square$ & $\square$ & $\square$ \\
\hline 24. LIMPEZA URBANA & $\square$ & $\square$ & $\square$ & $\square$ & $\square$ \\
\hline 25. LATÕES DE LIXO & $\square$ & $\square$ & $\square$ & $\square$ & $\square$ \\
\hline 26. ILUMINAÇÃO PUBLICA & $\square$ & $\square$ & $\square$ & $\square$ & $\square$ \\
\hline 27. TELEFONE UBLICO & $\square$ & $\square$ & $\square$ & $\square$ & $\square$ \\
\hline 28. TELEFONE CELULAR & $\square$ & $\square$ & $\square$ & $\square$ & $\square$ \\
\hline 29. SERVIÇO DE TRANSPORTE DE USSO PUBLICO & $\square$ & $\square$ & $\square$ & $\square$ & $\square$ \\
\hline 30. SEGURANÇA & $\square$ & $\square$ & $\square$ & $\square$ & $\square$ \\
\hline 31. SERVIÇOS MÉdICOS/HOSPITALARES & $\square$ & $\square$ & $\square$ & $\square$ & $\square$ \\
\hline
\end{tabular}

\section{AVALIAÇÃO DOS ATRATIVOS DO MUNICÍPIO}

\begin{tabular}{lcccc}
\hline & ÓTIMO & BOM & REGULAR & RUIM \\
\hline 32. ACESSO AOS ATRATIVOS & $\square$ & $\square$ & $\square$ & $\square$ \\
\hline 33. INFRA-ESTRUTURA DOS ATRATIVOS & $\square$ & $\square$ & $\square$ & $\square$ \\
\hline 34. SINALIZAÇÃO ATÉ OS ATRATIVOS & $\square$ & $\square$ & $\square$ & $\square$ \\
\hline 35. SINALIZAÇÃO DENTRO DOS ATRATIVOS & $\square$ & $\square$ & $\square$ \\
\hline 36. LIMPEZA DOS ATRATIVOS & $\square$ & $\square$ & $\square$ \\
\hline 37. PATRIMÔNIO HISTÓRICO & $\square$ & $\square$ & $\square$ \\
\hline 38. MATAS & $\square$ & $\square$ & $\square$ \\
\hline 39. RIOS/CACHOEIRAS/LAGOS & $\square$ & $\square$ & $\square$ \\
\hline 40. MONUMENTOS & $\square$ & $\square$ & $\square$ \\
\hline 41. CAVERNAS/GRUTAS/SERRAS/MORROS & $\square$ & $\square$ \\
\hline
\end{tabular}

\section{AVALIAÇÃO DOS EQUIPAMENTOS E SERVIÇOS TURÍSTICOS DO MUNICÍPIO}

\begin{tabular}{|c|c|c|c|c|c|}
\hline & О́тıмо & Bom & REGULAR & RUIM & PÉssimo \\
\hline 42. HOSPEDAGEM & $\square$ & $\square$ & $\square$ & $\square$ & $\square$ \\
\hline 43. ALIMENTAÇÃO & $\square$ & $\square$ & $\square$ & $\square$ & $\square$ \\
\hline 44. INFORMAÇÕES & $\square$ & $\square$ & $\square$ & $\square$ & $\square$ \\
\hline 45. HOSPITALIDADE & $\square$ & $\square$ & $\square$ & $\square$ & $\square$ \\
\hline 46. ATENDIMENTO & $\square$ & $\square$ & $\square$ & $\square$ & $\square$ \\
\hline 47. ENTRETENIMENTOS & $\square$ & $\square$ & $\square$ & $\square$ & $\square$ \\
\hline 48. PREÇOS & $\square$ & $\square$ & $\square$ & $\square$ & $\square$ \\
\hline
\end{tabular}

\section{Questionário cedido Pelo grupo Nativa e ADAPTAdo Pelo NúCleo de Pesquisa de Goiás}




\section{Questionário - Férias de Julho / 2003}

\begin{tabular}{|c|c|c|c|c|}
\hline DATA: & I & HORA & PESQUISADOR: & CIDADE: \\
\hline LOCAL: & & & \multicolumn{2}{|c|}{$\begin{array}{lc}\text { ALTA TEMPORADA: } & \square \text { FERIADO } \\
\text { BAIXA TEMPINAL DE SEMANA COMUM } & \square \text { DIAS ÚTEIS } \\
\end{array}$} \\
\hline \multicolumn{5}{|c|}{ QUESTIONÁRIO PARA VISITANTES } \\
\hline
\end{tabular}

\section{PERFIL DO VISITANTE}

1. LOCAL DE RESIDÊNCIA: CIDADE:

\begin{tabular}{|c|c|c|c|c|c|}
\hline \multirow[t]{2}{*}{ 2. SEXo: } & $\square$ MASCULINO & 3. IDADE: & $\square 15-19$ & $\square 20-29$ & $\square$ 30-39 \\
\hline & $\square$ FEMININO & & $\square 40-49$ & $\square 50-59$ & $\square 60$ OU MAIS \\
\hline
\end{tabular}

4. HÁBITO DE VIAGEM $\square$ SOZINHO $\square$ CASAL $\square$ COM FAMÍLIA $\square$ COM AMIGOS $\square$ COM FAMÍLIA E AMIGOS $\square$ EXCURSÃo

5. Agrupamento:

6. MEIO de TRANSPORTE: $\square$ CARRO $\square$ ÔNIBUS $\square$ MOTO $\square$ AVIÃo OUTROS

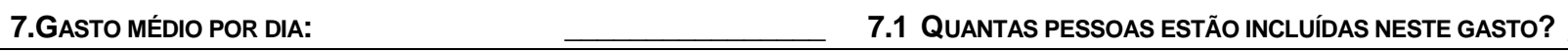

\begin{tabular}{|c|c|c|c|c|}
\hline \multirow[t]{2}{*}{ 8. LOCAL DE HOSPEDAGEM: } & \multicolumn{2}{|c|}{$\square$ HOTEL / POUSADA / APART-HOTEL } & $\square$ CASA ALUGADA & \multirow[t]{2}{*}{$\square$ CASA DE AMIGOS / PARENTES } \\
\hline & $\square$ CAMPING & $\square$ CASA PRÓPRIA & $\square$ OUTROS & \\
\hline \multirow[t]{3}{*}{ 9. MOTIVO DA VIAGEM: } & $\square$ TURISMO & $\square$ Negócios & $\square$ CONGRESSO & $\square$ RELIGIÃO/PEREGRINAÇÃO \\
\hline & \multicolumn{2}{|c|}{$\square$ VISITAR FAMILIARES / AMIGOS } & $\square$ EsTUDO & $\square$ TRATAMENTO DE SAÚDE \\
\hline & \multicolumn{2}{|l|}{ OUTROS } & & \\
\hline
\end{tabular}

10. TEMPO DE PERMANÊNCIA:

11. COMO VOCÊ FICOU SABENDO $\square$ FOLDERS/GUIAS $\square$ INTERNET $\square$ INFORMAÇÃo DE PARENTES / AMIGOS $\square$ JORNAL $\square$ REVISTA $\square$ RÁDIO SOBRE ESTE LUGAR/ESTA REGIÃO? ITELEVISÃo OUTROS

\begin{tabular}{|c|c|c|c|c|}
\hline 12. ESCOLARIDADE: & $\square$ FUNDAMENTAL & $\square$ MÉDIO $\square$ SUPERIOR & $\square$ Pós-GRADUAÇÃo & \\
\hline 13. LOCAL DE TRABALHO: & $\begin{array}{l}\square \text { EMPREGO PRIVADO } \\
\square \text { ESTUDANTE }\end{array}$ & $\begin{array}{l}\square \text { EMPREGo PÚBLICO } \\
\square \text { APOSENTADO }\end{array}$ & $\begin{array}{l}\square \text { PROFISSIONAL LIBERAL } \\
\square \text { Do LAR }\end{array}$ & $\square$ EMPRESÁRIO \\
\hline
\end{tabular}

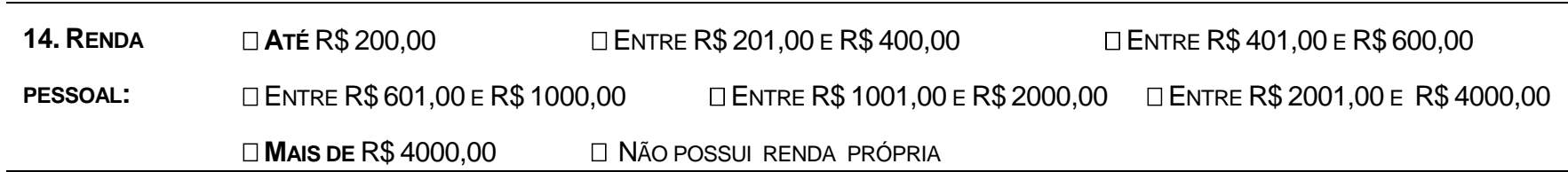

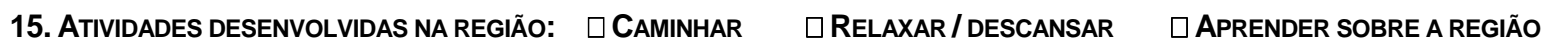

\begin{tabular}{|c|c|c|}
\hline$\square$ APRECIAR A NATUREZA & $\square$ ESOTERISMO / MISTICISMO & $\square$ ATIVIDADES NÁUTICAS \\
\hline$\square$ VISITAR CAVERNAS & $\square$ RIOS / CACHOEIRAS / LAGOS & $\square$ ESTUDO / PESQUISA \\
\hline$\square$ GASTRONOMIA & $\square$ RELIGIÃo & IVIDADE \\
\hline
\end{tabular}

\begin{tabular}{lll}
\hline 16. JÁ VISITOU O MUNICÍPIO? & $\square$ JÁ VISITOU ANTES & $\square$ PRIMEIRA VISITA \\
\hline 17. PRETENDE VOLTAR? & $\square$ SIM & $\square$ NÃO \\
& EM CASO NEGATIVO, POR QUÊ? & \\
\hline
\end{tabular}

18. ENCONTROU GUIA NA REGIÃO? $\square$ SIM $\square$ NÃo

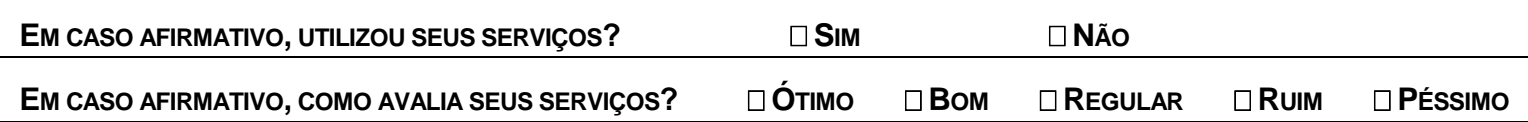




\section{PERCEPÇÃO DO VISITANTE}

OBS.: EM CASO DE DESCONHECIMENTO, NÃO RESPONDER.

\section{AVALIAÇÃO DA INFRA-ESTRUTURA DO MUNICÍPIO}

\begin{tabular}{|c|c|c|c|c|c|}
\hline & Óтıмо & Вом & REGULAR & RuIM & PÉssiMo \\
\hline 21. ACESSO AO MUNICÍPIO & $\square$ & $\square$ & $\square$ & $\square$ & $\square$ \\
\hline 22. SINALIZAÇÃO NAS RODOVIAS & $\square$ & $\square$ & $\square$ & $\square$ & $\square$ \\
\hline 23. SINALIZAÇÃO DENTRO DO MUNICÍPIO & $\square$ & $\square$ & $\square$ & $\square$ & $\square$ \\
\hline 24. APARÊNCIA DA CIDADE & $\square$ & $\square$ & $\square$ & $\square$ & $\square$ \\
\hline 25. LIMPEZA URBANA & $\square$ & $\square$ & $\square$ & $\square$ & $\square$ \\
\hline 26. LATÕES DE LIXO & $\square$ & $\square$ & $\square$ & $\square$ & $\square$ \\
\hline 27. ILUMINAÇÃO PÚBLICA & $\square$ & $\square$ & $\square$ & $\square$ & $\square$ \\
\hline 28. SERVIÇO DE TELEFONIA & $\square$ & $\square$ & $\square$ & $\square$ & $\square$ \\
\hline 29. SERVIÇO DE TRANSPORTE DE USO PÚBLICO & $\square$ & $\square$ & $\square$ & $\square$ & $\square$ \\
\hline 30. SEGURANÇA & $\square$ & $\square$ & $\square$ & $\square$ & $\square$ \\
\hline 31. SERVIÇOS MÉDICOS / HOSPITALARES & $\square$ & $\square$ & $\square$ & $\square$ & $\square$ \\
\hline
\end{tabular}

\section{AVALIAÇÃO DOS ATRATIVOS DO MUNICÍPIO}

\begin{tabular}{|c|c|c|c|c|c|}
\hline & Óтімо & Bom & REGULAR & RUIM & PÉSSIMO \\
\hline 32. ACESSO AOS ATRATIVOS & $\square$ & $\square$ & $\square$ & $\square$ & $\square$ \\
\hline 33. SINALIZAÇÃO ATÉ OS ATRATIVOS & $\square$ & $\square$ & $\square$ & $\square$ & $\square$ \\
\hline 34. SINALIZAÇÃO DENTRO DOS ATRATIVOS & $\square$ & $\square$ & $\square$ & $\square$ & $\square$ \\
\hline 35. LIMPEZA DOS ATRATIVOS & $\square$ & $\square$ & $\square$ & $\square$ & $\square$ \\
\hline 36. PATRIMÔNIO HISTÓRICO & $\square$ & $\square$ & $\square$ & $\square$ & $\square$ \\
\hline 37. MATAS & $\square$ & $\square$ & $\square$ & $\square$ & $\square$ \\
\hline 38. RIOS/CACHOEIRAS/LAGOS & $\square$ & $\square$ & $\square$ & $\square$ & $\square$ \\
\hline 39. MONUMENTOS & $\square$ & $\square$ & $\square$ & $\square$ & $\square$ \\
\hline 40. CAVERNAS/GRUTAS/SERRAS/MORROS & $\square$ & $\square$ & $\square$ & $\square$ & $\square$ \\
\hline 41. SEGURANÇA NOS ATRATIVOS & $\square$ & $\square$ & $\square$ & $\square$ & $\square$ \\
\hline
\end{tabular}

\section{AVALIAÇÃO DOS EQUIPAMENTOS E SERVIÇOS TURÍSTICOS DO MUNICÍPIO}

\begin{tabular}{lcccc}
\hline & ÓTIMO & BOM & REGULAR & RUIM \\
\hline 42. HOSPEDAGEM & $\square$ & $\square$ & $\square$ & $\square$ \\
\hline 43. ALIMENTAÇÃO & $\square$ & $\square$ & $\square$ & $\square$ \\
\hline 44. INFORMAÇÕES & $\square$ & $\square$ & $\square$ & $\square$ \\
\hline 45. HOSPITALIDADE & $\square$ & $\square$ & $\square$ \\
\hline 46. ATENDIMENTO & $\square$ & $\square$ & $\square$ \\
\hline 47. ENTRETENIMENTOS & $\square$ & $\square$ & $\square$ \\
\hline 48. PREÇOS & $\square$ & $\square$ & $\square$ \\
\hline
\end{tabular}

\section{QUESTIONÁRIO CEDIDO PELO GRUPO NATIVA E ADAPTADO PARA A PESQUISA}




\section{REFERENCIAS BIBLIOGRÁFICAS}

ANDRADE, José Vicente de. Turismo Fundamentos e dimensões. 8. ed. São Paulo:Ática, 2000. 215p

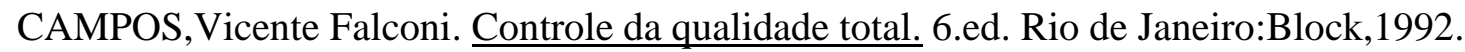

CARVALHO, N.C. Construindo o Saber: Metodologia Científica: Fundamentos e Técnicas. Campinas:Papirus,1998.

COBRA, Marcos. Administração de Marketing. 2. ed. São Paulo: Atlas, 1992.

DEMO, Pedro. Pesquisa e informação qualitativa: aporte metodológico. Campinas/SP: Papirus, 2001.

GONÇALVES, Anchizes do Egito Lopes et al. Planejamento estatístico do turismo. Rio de Janeiro, 1984.

LUNA, Sergio Vasconcelos de. Planejamento de pesquisa: uma introdução. Série Trilhas; São Paulo: EDUC, 2002.

OLIVEIRA, Claudionor dos Santos. Metodologia científica: planejamento e técnicas de pesquisa. Uma Visão Holística do Conhecimento Humano. São Paulo: LTr. 2000.

OLIVEIRA, Antônio Pereira. Turismo e Desenvolvimento: Planejamento e Organização. 4. ed. São Paulo: Atlas, 2002. 287p.

PÁDUA, Elisabete Matalho Marchesini. Metodologia da Pesquisa: abordagem teórica/prática. 8. ed. Campinas/SP: Papirus, 2000. (Coleção Magistério: Formação e Trabalho Pedagógico). RANGEL, Alexandre. Momento da qualidade. São Paulo: Atlas,1995.

REAL, Bismarque Villa. Inventario e Diagnóstico Turístico do Município de Pirenópolis. Goiânia:AGETUR/EMBRATUR,2001.

REJOWSKI, Mirian.Turismo e Pesquisa Científica. 3. ed.São Paulo: Papirus, 1996.

SÂMARA, Beatriz Santos e BARROS, José Carlos de. Pesquisa de Marketing - Conceitos e Metodologia. 2. ed. São Paulo:Makron Books,1997. 
SENAC.DN. Qualidade em prestação de serviços. org. Francisco Flávio de a Rodrigues; Maria Leonor de M. S. Leal; Lourdes Hargreaves. Ed. Ver e ampl. Rio de Janeiro: SENAC/DN/DEP, 1999. 88 p.

Apostilas do Curso de Especialização para Professores e Pesquisadores em Turismo e Hospitalidade - CET/UnB - Brasília /DF:

Gestão de Pessoas - Disciplina 14:

Texto I: Capitulo 1: Definindo Conhecimento Cientifico (págs. 13 a 43)

Texto II: Capitulo 2: Conhecimento Científico e Complexidade (págs. 44 a 73)

Texto IV: Capitulo 1: Turismo, Hotelaria e Hospitalidade - Luiz Octávio de Lima Camargo. (págs. 1 a 37)

Texto V: Capitulo 3: Dados em Estudos Organizacionais - Ralph Stablein (págs. 63 a 117)

Estratégias Metodológicas para Ensino e Pesquisa: O Projeto da Monografia - Disciplina 8:

Texto 1: Turismo como Disciplina no Pensamento Internacional - Mirian Rejowski (págs. 13 a 58)

Texto 7: Etapas da Pesquisa Qualitativa - Ada de Freitas Maneti Dencker (págs. 61 a 96)

Economia Aplicada ao Turismo - Disciplina 16:

Texto 1: Resumo da Conta Satélite de Turismo (págs. 1 a 39)

Texto 2: Turismo e desenvolvimento econômico - o caso dos países em desenvolvimento (págs. 1 a 5$)$.

Texto 3: Estudo do Mercado Doméstico de Turismo no Brasil - FIPE (Fundação Instituto de Pesquisas Econômicas), (págs. 32 a 38).

Artigo de revista: Marcos Coronato, A locomotiva do Cerrado. EXAME, págs 4 a 26, abril de 2003.

EMBRATUR. Boletim de Ocupação Hoteleira.

EMBRATUR. Conta Satélite do Turismo, 1999.

EMBRATUR. Ficha Nacional de Registro de Hóspedes.

GRUPO NATIVA. Cenário- Sistema de Inventário da Oferta Turística.

SANTA CATARINA. SANTUR. Estudo da Demanda Turística. 
Show Case Goiás - AGETUR - Agencia Goiana de Turismo.

BORGES Marcos, Martins. Proposta de pesquisa com visitantes em Pirenópolis. College Station, Texas, 2003. 